\title{
Students' Interests in Agriculture: The Impact of School Farms Regarding Fifth and Sixth Graders
}

\author{
Dissertation \\ Zur Erlangung des mathematisch-naturwissenschaftlichen \\ Doktorgrades \\ "Doctor rerum naturalium" \\ der Georg-August-Universität Göttingen \\ Promotionsstudiengang „Biodiversität und Gesellschaft“ \\ Basisprogramm Biologie \\ der Georg-August-University School of Science (GAUSS) \\ vorgelegt von Malte Bickel \\ aus Marburg
}

Göttingen 2014 


\section{Mitglieder des Betreuungsausschusses:}

Prof. Dr. Susanne Bögeholz, Didaktik der Biologie, Albrecht-von-Haller-Institut für Pflanzenwissenschaften

PD. Dr. Micha Strack, Georg-Elias-Müller-Institut für Psychologie

\section{Mitglieder der Prüfungskommission:}

Referentin: Prof. Dr. Susanne Bögeholz, Didaktik der Biologie, Albrecht-von-HallerInstitut für Pflanzenwissenschaften

Korreferentin: PD. Dr. Micha Strack, Georg-Elias-Müller-Institut für Psychologie

Weitere Mitglieder der Prüfungskommission:

Prof. Dr. Stefan Halverscheid, Didaktik der Mathematik, Mathematisches Institut

Prof. Dr. Johannes Isselstein, Abteilung Graslandwissenschaft, Department für Nutzpflanzenwissenschaften

Prof. Dr. Christoph Leuschner, Ökologie und Ökosystemforschung, Albrecht-vonHaller-Institut für Pflanzenwissenschaften

Prof. Dr. Susanne Schneider, Didaktik der Physik, IV. Physikalisches Institut

Tag der mündlichen Prüfung: 
"Nichts kommt ohne Interesse zustande."

(Georg Wilhelm Friedrich Hegel)

"I sincerely believe that for the child, and for the parent seeking to guide him, it is not half so important to know as to feel. If facts are the seeds that later produce knowledge and wisdom, then the emotions and the impressions of the senses are the fertile soil in which the seeds must grow."

(Carson, 1965, p. 46) 


\section{Acknowledgements}

During the past years, many people supported me in conducting this doctoral thesis in many different ways. I would like to thank all of you!

From the first project idea to the publication of the results, the intensive conversations and discussions with Prof. Dr. Susanne Bögeholz and PD Dr. Micha Strack were a great help. Being examined in organic agricultural sciences, I learned a lot about research in biology education. Thanks to you, Micha, and your vivid explanations, I broadened my horizon concerning statistics and research methodology beyond information contained in textbooks.

I gratefully appreciate the effort of all the students who took part in this study and patiently filled many questionnaires. In this context, I am also obliged to all participating teachers for their great support in implementing the survey and conducting the learning unit in school subsequent to the farm stay. Special thanks go to Anne Duisen for testing and improving the learning units in the frame of her Master thesis.

This study would not have been possible without the collaboration of the school farms. My gratitude goes especially to Michaela and Holger Schenke from Hutzelberghof, Tanja Plümer from Gut Hohenberg, Gabi Ankewitz and Sigrid Kownatzki from Schulbauernhof Ummeln, Jochen Rittberger from Schulbauernhof Zukunftsfelder as well as Axel Unger from Internationaler Schulbauernhof who have been a great help in coordinating and conducting the surveys. Moreover, I would like to acknowledge the decent work of all the people who are engaged on educational farms or strive to push forward farm education on all levels as a significant contribution for society.

I am grateful to my current and former colleagues at the biology education department, Sonja Arens, Marko Böhm, Patricia Bönig, Sabina Eggert, Helge Gresch, Cora Joachim, Sebastian Koch, Johanna Löber, Melanie Möhlhenrich, Anne Nitsch, Frauke Ostermeyer, Rubina Schatz, Stephan Teschner, and Carolin Ziese for sharing a lot of time in the office, at lunch, during coffee breaks and for the conversations about ups and downs in the process of writing a doctoral thesis.

Next, I would like to thank all the doctoral students and coordinators of the PhD program "Biodiversity and Society". The program offers a unique opportunity to assemble many different disciplines and perspectives working on the essential issue of biodiversity and thus to gain an insight into other branches of study even if the interdisciplinary collaboration does not always proceed smoothly. For financial support, I am obliged to the Ministry for Science and Culture of the federal state of Lower Saxony that provided the scholarships in the scope of the PhD program. Furthermore, I am grateful to the Göttinger Graduiertenschule Gesellschaftswissenschaften for providing financial sustenance during the last six months. 
I express very special thanks to Marina Hethke, curator of the tropical greenhouse at the University Kassel / Witzenhausen, for my "second office" in Witzenhausen, the cooperation in teaching the course Umweltkommunikation, and the professional and personal exchange.

For moral support throughout the last years (and those before), I thank my parents Ute and Helmut who always believe in me and are a great backing through providing their confidence. Bow, a particular thanks for all the proofreading of my English texts.

I thank my wife Johanna and my kids Liam and Jara for being there: Johanna, for taking the load off me, in particular during the last phase of the dissertation; Liam and Jara for your great success in breaking my "circling thoughts" when coming home. It is a pleasure to share this life with you! 


\section{Danksagung}

Während der vergangenen Jahre haben mich viele Menschen bei dieser Doktorarbeit in unterschiedlicher Weise begleitet und unterstützt, denen ich hier meinen Dank aussprechen möchte.

Von der ersten Projektidee bis zur Veröffentlichung der Ergebnisse waren die intensiven Gespräche und Diskussionen mit Prof. Dr. Susanne Bögeholz und PD Dr. Micha Strack eine große Hilfe. Dabei habe ich-als studierter ÖkoAgrarwissenschaftler-viel über die biologiedidaktische Forschungspraxis gelernt. Dank dir, Micha, und deinen wirklich anschaulichen Erläuterungen konnte ich in ungeahnte Sphären der Statistik eintauchen und mir Anwendungen sozialwissenschaftlicher Forschungsmethodik jenseits des in Lehrbüchern vermittelten Wissens aneignen.

Ein großer Dank geht an alle Schülerinnen und Schüler, die an der Studie teilgenommen und die vielen Fragebögen mit Geduld ausgefüllt haben. In diesem Zusammenhang ist insbesondere auch den beteiligten Lehrkräften ein Dank auszusprechen, die mich bei der Durchührung der Befragungen maßgeblich unterstützt sowie die schulischen Nachbereitungen der Bauernhofaufenthalte durchgeführt haben. Mein ausdrücklicher Dank geht an Anne Duisen, die im Rahmen ihrer Masterarbeit die schulischen Lerneinheiten testete und maßgeblich an deren Optimierung beteiligt war.

Die Umsetzung dieser Studie wäre ohne die Mitarbeit der Schulbauernhöfe nicht möglich gewesen. Mein Dank geht hier insbesondere an Michaela und Holger Schenke vom Hutzelberghof, Tanja Plümer vom Gut Hohenberg, Gabi Ankewitz und Sigrid Kownatzki vom Schulbauernhof Ummeln, Jochen Rittberger vom Schulbauernhof Zukunftsfelder sowie Axel Unger vom Internationalen Schulbauernhof, die bei der Koordination und der Umsetzung der vielen Erhebungen eine große Hilfe waren. Ferner möchte ich allen weiteren Aktiven danken, die sich für und auf dem Lernort Bauernhof engagieren und dort eine gesellschaftlich wertvolle Arbeit leisten.

Meinen aktuellen und ehemaligen Kolleginnen und Kollegen aus der Didaktik der Biologie-Sonja Arens, Marko Böhm, Patricia Bönig, Sabina Eggert, Helge Gresch, Cora Joachim, Sebastian Koch, Johanna Löber, Melanie Möhlhenrich, Anne Nitsch, Frauke Ostermeyer, Rubina Schatz, Stephan Teschner und Carolin Ziese-danke ich für die gemeinsam verbrachte Zeit im Büro, beim Mittagessen, Cappuccino-Trinken und den Austausch über Höhen und Tiefen des Promotionsprozesses.

Ebenso danke ich allen Promovierenden und den Koordinatoren des Promotionsstudiengangs Biodiversität und Gesellschaft. Der Studiengang stellt eine einzigartige Möglichkeit dar, das so wichtige Themenfeld Biodiversität aus verschiedensten Disziplinen und Blickwinkeln zu bearbeiten und dabei Einblicke in 
andere Fachrichtungen zu gewinnen, auch wenn die interdisziplinäre Zusammenarbeit nicht immer reibungslos vonstattengeht. Für die finanzielle Unterstützung danke ich dem Land Niedersachsen, das die Stipendien im Rahmen des Promotionsstudiengangs zur Verfügung stellte, sowie der Göttinger Graduiertenschule Gesellschaftswissenschaften, die mich in den letzten sechs Monaten finanziell unterstützte.

Ganz besonderer Dank gilt Marina Hethke, Kustodin des tropischen Gewächshauses der Universität Kassel / Witzenhausen, für mein „Zweitbüro“ in Witzenhausen, die Zusammenarbeit bei der Lehre im Modul Umweltkommunikation sowie den fachlichen und persönlichen Austausch darüber hinaus.

Für die moralische Unterstützung während der Promotionszeit (und davor) danke ich meinen Eltern Ute und Helmut, die immer an mich glauben und mir durch ihr Zuund Vertrauen einen starken Rückhalt geben. Bow, Dir ein besonderer Dank für das Korrekturlesen meiner diversen englischen Texte.

Meiner Frau Johanna und meinen Kindern Liam und Jara danke ich dafür, dass sie da sind. Johanna, dafür dass du mir insbesondere in der letzten Phase der Promotion den Rücken freigehalten hast; Liam und Jara dafür, dass ihr es immer wieder geschafft habt, mich aus den mit nach Hause gebrachten Gedankenkreisen herauszuholen. Es ist wunderschön, dieses Leben mit euch zu teilen! 


\section{Abstract}

The present way of intensive agricultural production is closely connected to central issues of sustainable development such as the loss of biodiversity and climate change. The corresponding importance of agriculture stands in contrast to the fact that large parts of society and in particular young members are vastly decoupled from agriculture due to altered living conditions and the structural change in agriculture. Targeted educational programs try to revive the interest of young people in agriculture in order to dispel this discrepancy. In this context, farm education plays a central role as an experience-based and hands-on out-of-school-learning opportunity.

The present study analyzes students' interests in agricultural content areas and their influencing factors. Therefore, a suitable test instrument had to be developed first. Moreover, the potential of a five-day school farm stay with agricultural work experience and a consecutive learning unit in school were investigated with regard to the development of students' agricultural interests. To do so, a quantitative survey was conducted including four measurement points. Sources of situational interest were determined at both interventions and the interrelationship between situational interest and individual interest in agriculture was considered.

The first two studies reveal the development and validation of a test instrument that was composed as a factorial design with four components of individual interest and five agricultural content areas. Besides, the second study proves the importance of prior knowledge, nature experiences, disgust sensitivity, and gender as predictors of interest in agriculture and its content areas.

School farm stays of five days duration with hands-on work experiences in various agricultural content areas increased students' interests in some content areas; this holds in particular for boys, as study 3 demonstrates.

In the fourth empirical contribution a model of agricultural interest development with two consecutive extracurricular and curricular treatments was derived from different branches of prior interest research. The results reveal that a consecutive learning unit in school subsequent to the farm stay could maintain the increased levels of interest, which, decreased in the medium term five weeks later, however. Concerning situational interest in working on the school farm, especially the subjective experience of one's own competence, but also perceived autonomy and social relatedness were of importance. Situational interest in the learning unit in school was better facilitated by a combination of instructional catch and hold elements in comparison to other variants of the same learning unit that contained either catch or hold elements only. In the course of interest development throughout the four measurements, reciprocal influences of situational and individual interest became apparent. Overall, the thesis argues for repeated educational interventions in agricultural contexts in order to strengthen related individual interests in the long run. 


\section{Zusammenfassung}

Die gegenwärtige Form der Landwirtschaft steht in engem Zusammenhang mit zentralen Themen der nachhaltigen Entwicklung wie dem Verlust der Biodiversität und dem Klimawandel. Der daraus resultierenden steigenden Bedeutung von Landwirtschaft steht eine weitgehende Abkopplung insbesondere junger Bevölkerungsschichten gegenüber, bedingt durch veränderte Lebensbedingungen und den landwirtschaftlichen Strukturwandel. Um dieser Diskrepanz zu begegnen, bestehen Bestrebungen, das Interesse junger Menschen an Landwirtschaft im Rahmen von gezielten Bildungsmaßnahmen (wieder) zu beleben. Eine zentrale Rolle kommt dabei dem Bauernhof als erfahrungsintensivem und handlungsorientiertem Lernort zu.

Ein Ziel dieser Studie war die Analyse von Schülerinteressen an landwirtschaftlichen Themenbereichen und deren Einflussfaktoren und damit verbunden zunächst die Entwicklung eines geeigneten Messinstruments. Darauf aufbauend wurde die Entwicklung der Schülerinteressen an Landwirtschaft nach einem fünftägigen Schulbauernhofaufenthalt und einer daran anschließenden Lerneinheit in der Schule untersucht. Dafür wurde eine quantitative Schülerbefragung zu vier Messzeitpunkten durchgeführt. Zudem wurden während beider Interventionen Einflussfaktoren des situationalen Interesses bestimmt und wechselseitige Einflüsse von situationalem und individuellem Interesse analysiert.

Die ersten beiden Studien dokumentieren die Entwicklung und Validierung des faktoriellen Designs eines Messinstruments mit vier Interessekomponenten und fünf landwirtschaftlichen Themenbereichen. Die zweite Studie belegt zudem die Bedeutung von Vorwissen, Naturerfahrungen, Ekelsensitivität und Geschlecht als Einflussfaktoren der landwirtschaftlichen Interessensbereiche. Fünftägige Schulbauernhofaufenthalte mit aktiven Arbeitserfahrungen in verschiedenen landwirtschaftlichen Bereichen konnten die Schülerinteressen in einigen Bereichen steigern, wobei vor allem Jungen Interessenzuwächse erzielten, wie in Studie 3 deutlich wird.

Im vierten empirischen Beitrag wird ein Modell mit kombinierten außerschulischen und schulischen Interventionen zur Entwicklung landwirtschaftlichen Interesses beruhend auf verschiedenen Strängen bisheriger Interesseforschung abgeleitet. An den Schulbauernhofaufenthalt anschließende schulische Lerneinheiten konnten das gesteigerte Interesse aufrechterhalten, dieses sank jedoch weitere fünf Wochen später wieder. Bezüglich des situationalen Interesses bei der Arbeit auf dem Schulbauernhof waren vor allem das Kompetenzerleben, zudem wahrgenommene Autonomie und soziale Eingebundenheit von Bedeutung. Das situationale Interesse an der schulischen Einheit wurde durch die Verbindung von Catch- und Hold-Elementen stärker gefördert im Vergleich zu Varianten der Einheit, die nur catch- oder hold-Elemente integrierten. Im Zuge der Interessenentwicklung über die vier Messzeitpunkte zeigten sich wechselseitige Einflüsse des situationalen und individuellen Interesses. Diese Arbeit unterstreicht die Bedeutung wiederholter landwirtschaftlicher Bildungsinterventionen um diesbezügliche Interessen nachhaltig zu stärken. 


\section{Table of Contents}

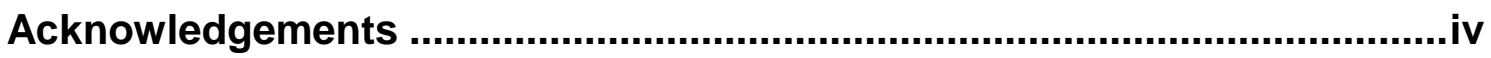

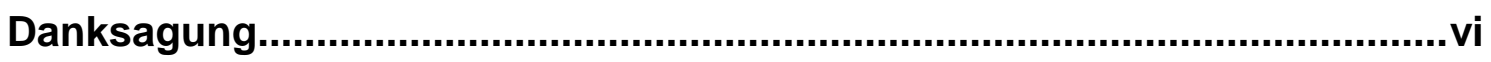

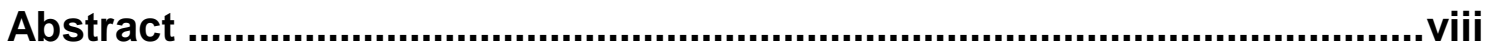

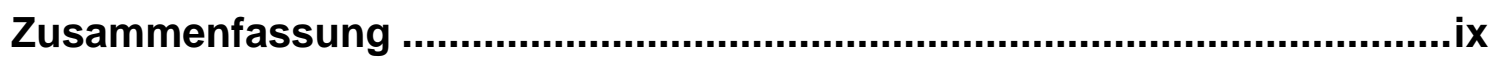

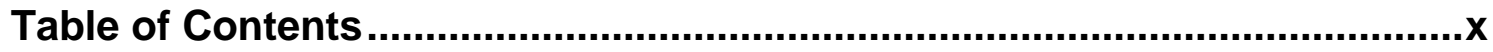

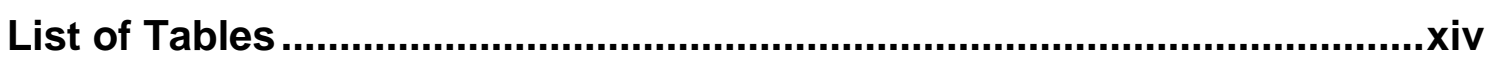

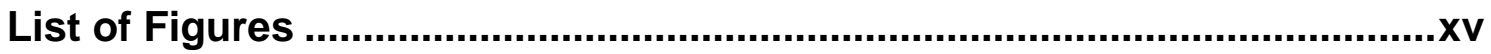

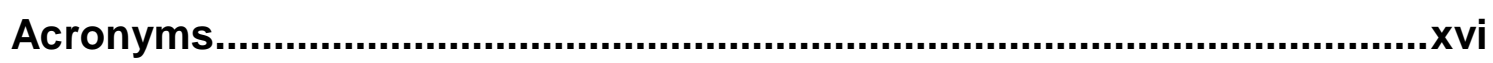

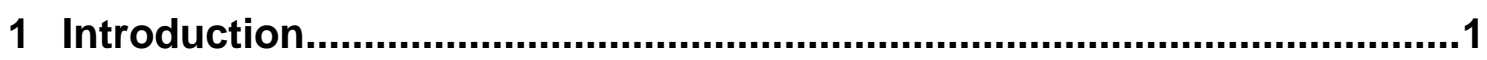

2 Agriculture as Context of Learning ...........................................................

2.1 The Structural Change in Agriculture during the $20^{\text {th }}$ Century and its Implications on Sustainable Development ..........................................

2.2 Curricular References to Agriculture .............................................

2.3 Extracurricular Learning on School Farms ......................................

3 Benefits of Farm Education and Related Approaches .............................. 8

4 Research on Interest and Interest Development ....................................13

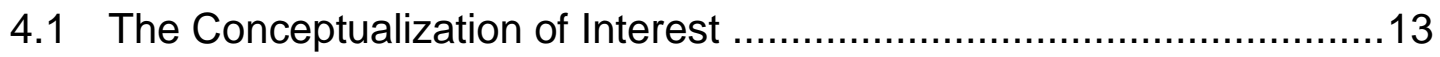

4.2 Situational and Individual Interest .................................................14

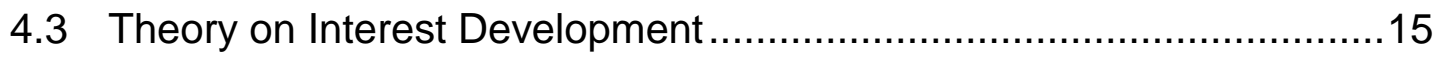

4.3.1 Conditions to Promote Situational Interest........................................15

4.3.2 The Development of Individual Interest .........................................17

4.4 Research on Agricultural Interests ............................................... 19

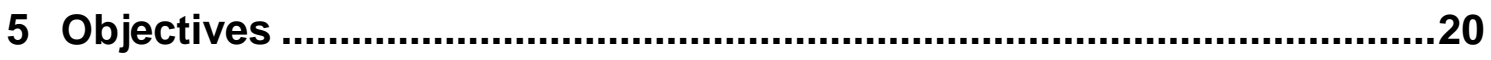

6 Schülerinteressen an landwirtschaftlichen Themen ...............................22

6.1 Hintergrund und Problemstellung................................................22

6.2 Methodische Vorgehensweise zur Erhebung der Schülerinteressen ...26

6.2.1 Messung der individuellen landwirtschaftsbezogenen Interessen.......26

6.2.2 Messung des situationalen Interesses........................................28

6.3 Ergebnisse zu individuellen landwirtschaftsbezogenen Schülerinteressen 
6.4 Diskussion und Ausblick .31

7 Measuring the Interest of German Students in Agriculture: The Role of Knowledge, Nature Experience, Disgust, and Gender ...........................33

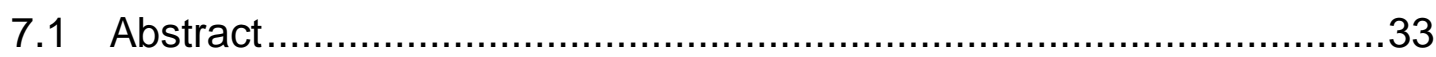

7.2 Agriculture as a Key Factor for Sustainable Development ...................33

7.3 Characteristics of Individual Interest and the State of the Art on Interest in Agriculture 34

7.4 Common Predictors of Individual Interest in Agriculture-related Objects. .36

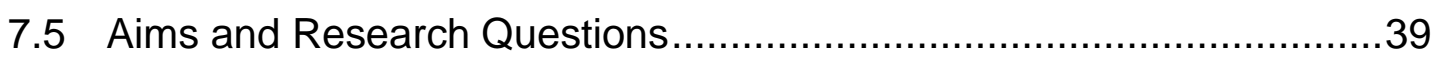

7.6 Method ............................................................................. 40

7.6.1 Participants and Procedure ................................................... 40

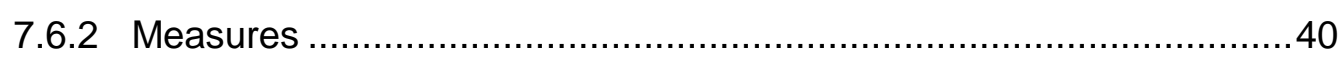

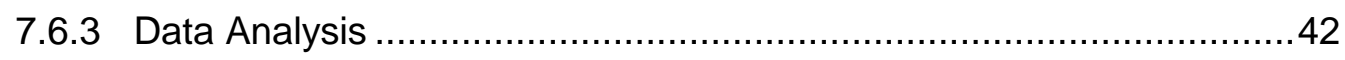

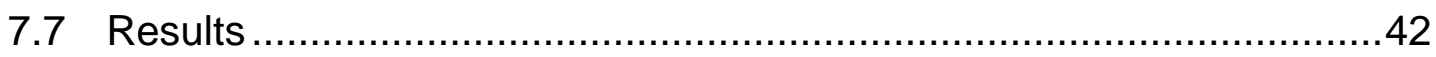

7.7.1 Variance Parts in the Factorial Model of Agricultural Interests ...........42

7.7.2 Predictors of Agricultural Interests ...............................................43

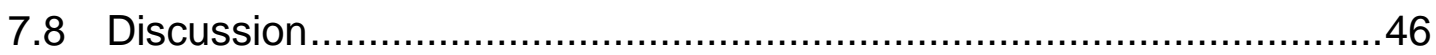

7.8.1 Construct Validation by Variance Partitioning ..................................47

7.8.2 Integration of Predictive Findings ............................................48

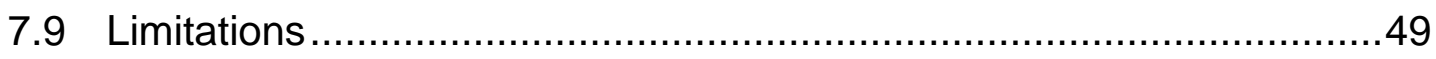

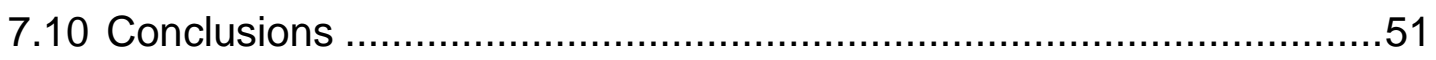

8 The Potential of School Farms to Foster Students' Interests in Agriculture: Animals Attract Girls and Hands-on Engages Boys? ........53

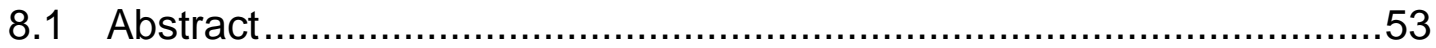

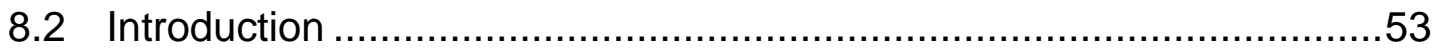

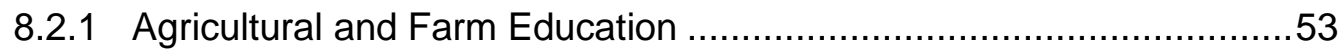

8.2.2 Prior Research on the Effectiveness of Farm Education.....................56

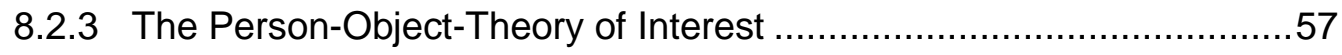

8.2.4 Program Duration as a Success Factor Concerning Interest and Behavioral Intentions in Outdoor Education......................................57

8.2.5 Hands-On Experience and Interest ...........................................58

8.2.6 Gender-Specificity in Agricultural and Related Interests ....................59

8.2.7 School Farms and their Potential to Foster Agricultural Interests........60

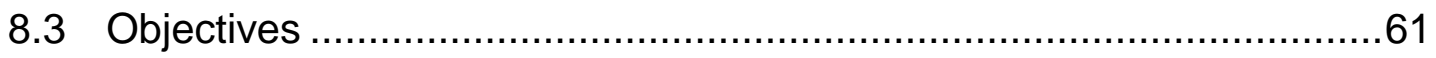

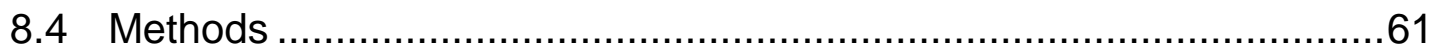




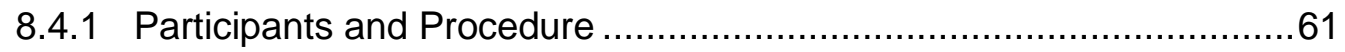

8.4.2 The School Farm Program .......................................................61

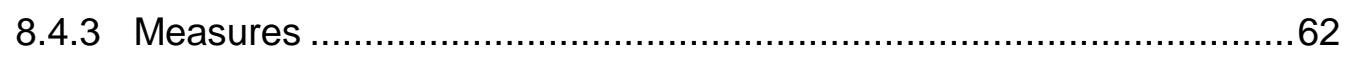

8.4 .4 Data Analysis ................................................................... 63

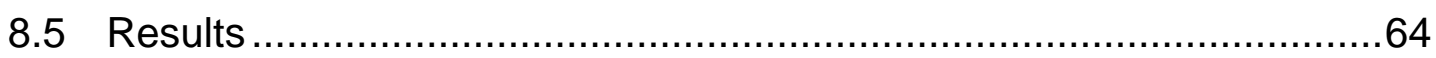

8.5.1 Global Effects of the School Farm Treatment and Work Experiences 64

8.5.2 Gender-specific Effects ...................................................... 64

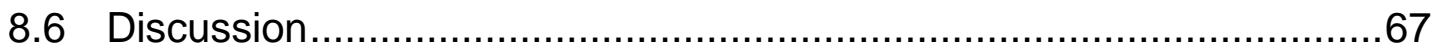

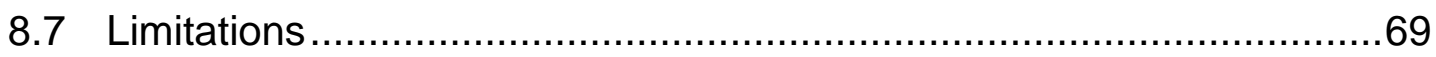

8.8 Implications and Perspectives .................................................. 70

9 A Model of Interest Development for Combined Extracurricular and Inschool Interventions: Situational Factors and the Interplay of Situational and Individual Interest .........................................................71

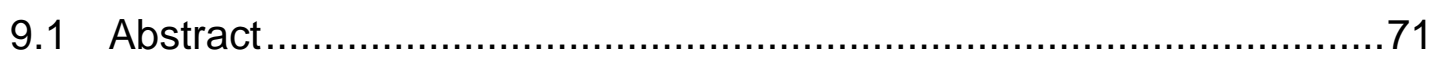

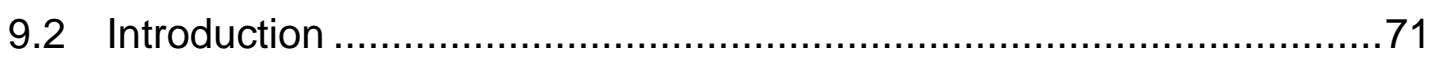

9.2.1 Individual and Situational Interest............................................ 72

9.2.2 Individual Interest Development ............................................. 73

9.2.3 Sources of Situational Interest................................................. 74

9.2.4 A Model of Interest Development ................................................ 77

9.2 .5 The Present Study............................................................. 79

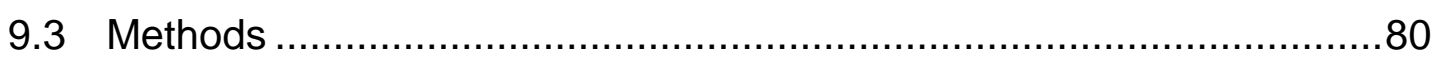

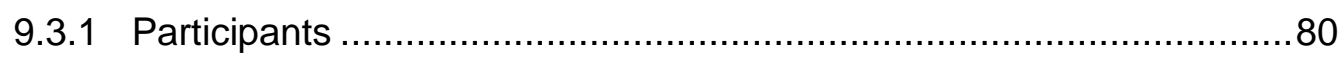

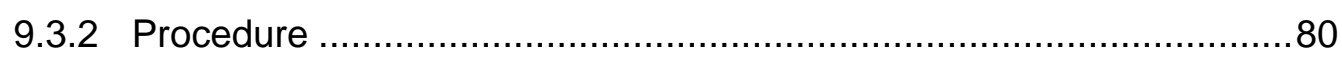

9.3.3 Residential School Farm Intervention ............................................8 80

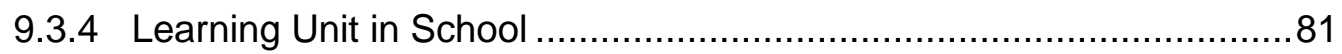

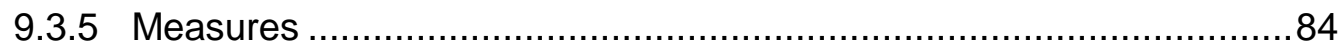

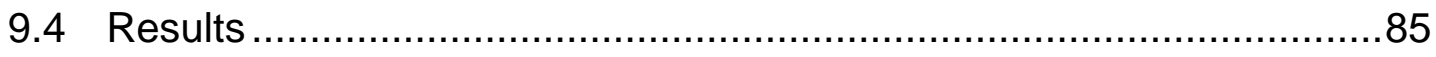

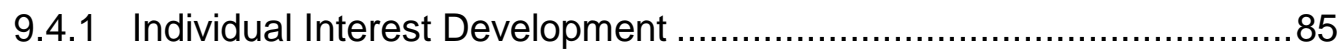

9.4.2 Catch and Hold Effects on Situational Interest in the Learning Unit ....86

9.4.3 Path Model on Situational and Individual Interest Development, Determinants, and Interrelations.................................................... 87

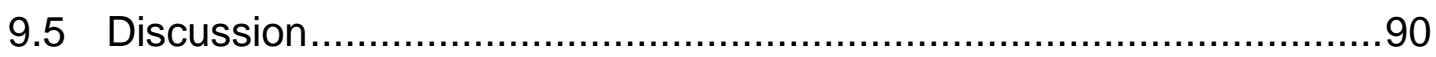

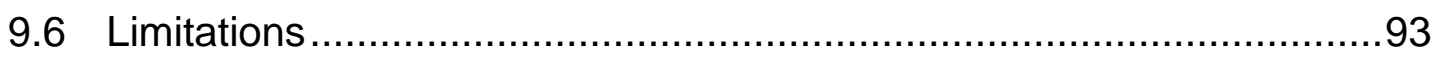

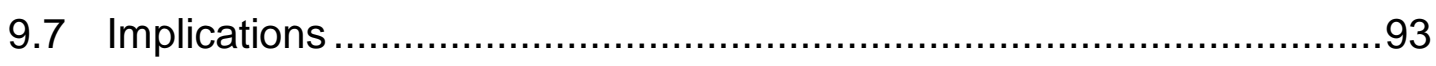

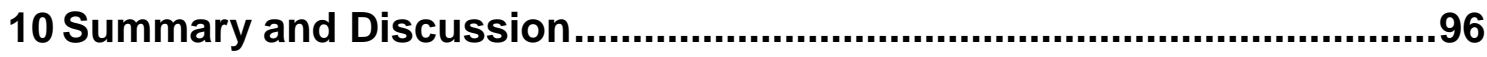

10.1 Measuring Agricultural Interests..................................................96 
10.2 Explaining Agricultural Interests..... .97

10.3 Gender-specificity within Agricultural Interests and the Impact of School Farms .98

10.4 The Impact of School Farm Experiences and Instructional Catch and Hold Elements in Curricular Learning Units on Situational Interest....101

10.5 The Model of Agricultural Interest Development ..............................103

10.6 Methodological Reflections .......................................................106

10.7 Concluding Remarks and Prospects ............................................107

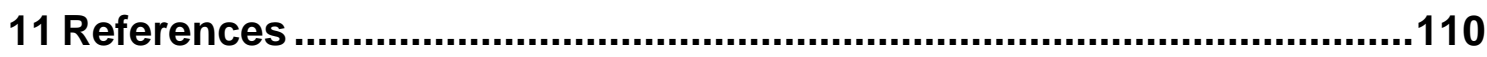

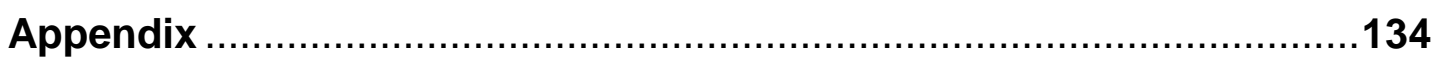


List of Tables

Tabelle 6.1: $\quad$ Ergebnisse der explorativen Faktorenanalyse zu individuellen Interessen an landwirtschaftlichen Themenbereichen unter Angabe des Reliabilitätskoeffizienten ( $\alpha$ ) für die identifizierten Faktoren

Tabelle 6.2: Ergebnisse der explorativen Faktorenanalyse zum situationalen Interesse an der Mitarbeit auf einem Schulbauernhof unter Angabe des Reliabilitätskoeffizienten ( $\alpha$ ) für die identifizierten Faktoren

Table 7.1: Stepwise regression of agricultural interests to gender, prior knowledge, garden experience, disgust sensitivity, frequency of farm visits, and keeping a pet (forward inclusion)

Table 8.1: $\quad$ Gender-specific agricultural interests after the school farm stay as a function of initial interest (control variable, step 1), school farm treatment and its interaction with initial interest (step 2), and work experience on the school farm in the respective content areas and their inter-action with initial interest (step 3, not applicable to arable farming and agricultural engineering)

Table 9.1: Schedule and operationalization of 'catch' and 'hold' elements in both double periods of the second intervention in school (multiple catch and/or hold elements within one phase are listed sequentially)

Table 9.2: $\quad$ Means, standard deviations, and zero-order correlations of all measured variables

Table 9.3: Hierarchical regression analyses of situational interest ratings during the school farm stay (T1) and during the learning unit in school (T2)

Table 10.1: Percentage of participants in the experimental group with maximum (minimum) initial interest (TO) in the agricultural content areas 


\section{List of Figures}

Figure 5.1: $\quad$ Core objectives of the present thesis 21

Abbildung 6.1 Landwirtschaftsbezogene Schülerinteressen 30

Abbildung 6.2 Geschlechtsspezifische landwirtschaftsbezogene

Schülerinteressen

Figure 7.1: Factorial design of the measure of agricultural interests

Figure 7.2: $\quad$ Variance parts in the structure of agricultural interests

Figure 9.1: Interrelations of situational and individual interest $(\mathrm{SI}=$ situational interest, II = individual interest

Figure 9.2: $\quad$ Postulated model of situational interest and individual interest development for learning contexts with extracurricular and inschool interventions (IA = interaction, solid black arrows $=$ paths to individual interest, dashed arrows = paths to situational interest, solid grey arrows = additional paths)

Figure 9.3: Situational interest in the learning unit in school (T2) as effected by the variants with catch-only, hold-only, and combined catch and hold elements

Figure 9.4: Influences of perceived autonomy, competence, and social relatedness ( $\mathrm{T} 1)$ and instructional catch and hold elements (T2) on situational interest, and interrelations of situational and individual interest 


\section{Acronyms}

BfN Bundesamt für Naturschutz (Federal Agency for Nature Conservation)

BLK Bund-Länder-Kommission für Bildungsplanung und Forschungs-

förderung (Commission of the Federal Republic of Germany and its states for educational strategies and research)

CBD Convention on Biological Diversity

DBV Deutscher Bauernverband (German Farmers‘ Association)

ESD Education for Sustainable Development

FAO Food and Agriculture Organization of the United Nations

II

Individual interest

IÖW

Institut für ökologische Wirtschaftsforschung (Institute for Ecological Economy Research)

KMK

Ständige Konferenz der Kultusminister der Länder in der Bundesrepublik Deutschland (The Standing Conference of the Ministers of Education and Cultural Affairs of the Länder in the Federal Republic of Germany)

MEA Millennium Ecosystem Assessment

SDT

Self-Determination Theory

SI

Situational interest 


\section{Introduction}

Agriculture represents a topic with various opportunities for science education and education for sustainable development, and farms as extracurricular places of learning offer a great educational potential (Dreyfus, 1987).

The current increasing importance of agricultural education traces back to tremendous structural changes in agriculture throughout Germany and other industrialized countries during the $20^{\text {th }}$ century. Agricultural mechanization (e.g., Binswanger, 1986; Henkel, 2012), the application of chemical fertilizers and pesticides (e.g., Leigh, 2004; Smil, 2004), and the successive process of specialization and intensification have led to great increases in agricultural productivity (DBV, 2013; Ramankutty, Foley, \& Olejniczak, 2002).

However, many environmental and sustainable development concerns are closely related to modern intensive farming systems (e.g., Geiger et al., 2010; Liess et al., 2005; Pachauri \& Reisinger, 2007; United Nations, 2012). Besides, the structural change in agriculture has disconnected people from farming. Since the coming generations will have to face these problems, educators and researchers complain about a lack in young people's primary agricultural knowledge (Brämer, 2010; Dillon, Rickinson, Sanders, \& Teamey, 2005; Trexler, 2000a, 2000b) and underline the importance to reconnect young people with agriculture in institutional learning (Dillon et al., 2005). Thus, agriculture once again becomes an increasingly important issue in science and geography education.

An educational approach to revive the relation of young people to agriculture is to address their respective interests. From an educational perspective, interest can be both a precious predisposition and a learning outcome. As an intrinsic motivational basis, it favors learning processes and fosters knowledge, achievement, and competence acquisition (e.g., Hidi \& Renninger, 2006; Wigfield \& Cambria, 2010).

So far, research has hardly considered agriculture as an object of students' interests. A sound instrument to investigate interest in different agricultural content areas is lacking. However, some potential factors how agricultural interest can be fostered were identified in related interest research. It seems likely that nature experiences are one important factor (Chawla \& Cushing, 2007; Leske \& Bögeholz, 2008). The manifold possible nature experiences on farms (Bögeholz, 2001, 2005)— and in particular intensive ones such as a five-day school farm stay-appear promising, especially in combination with supporting cognitive activities in school (Paas, Tuovinen, Merriënboer, \& Darabi, 2005; Scharfenberg \& Bogner, 2013).

Against this background, this study scrutinized agricultural interests of fifth and sixth grade students in fundamental agricultural content areas such as animal husbandry and plant production. The first aim was to develop a valid and reliable instrument to 
investigate agricultural interests. On this basis, influence factors of agricultural interests were determined. Furthermore, the effect of a five-day school farm stay with hands-on learning in combination with subsequent in-school instruction was evaluated concerning the development of agricultural interests. Conditions to promote situational interest in agricultural contexts on school farms and in school were analyzed. Besides, interrelations of situational interest with prior and subsequent states of individual interest in both interventions were examined. 


\section{Agriculture as Context of Learning}

This chapter starts with a brief historical sketch on why agricultural content has become and currently still becomes increasingly significant as part of institutional education (2.1). Agricultural references of-mainly biology and geography-curricula are presented (2.2). Chapter 2.3 highlights the concept of school farms as one approach to farm education.

\subsection{The Structural Change in Agriculture during the $20^{\text {th }}$ Century and its Implications on Sustainable Development}

In the past, agriculture had the task to provide people with food and huge parts of society lived on farming (Robinson \& Sutherland, 2002). However, the structural change in agriculture throughout the past century, which was caused by a "technical agricultural revolution", changed the whole agrarian sector tremendously (Henkel, 2012). Caused by rapid developments in agricultural engineering, most of the remaining agricultural entrepreneurs replaced many manual works throughout all kinds of production processes by machinery (Binswanger, 1986; Henkel, 2012; Knauss, 1998; Mazoyer \& Roudart, 2006; Seidl, 2006). Many farmers changed their enterprises towards a large scale production of few agricultural commodities. Besides technical innovations, the introduction of synthetic chemical fertilizers and pesticides led to a rapid growth in average yields and vastly intensified crop production (Leigh, 2004; Smil, 2004). As a consequence of the briefly outlined developments-mechanization, specialization, and intensification-the whole sector became much more productive. For instance, since 1900, the average yield of wheat has quadrupled (DBV, 2013).

However, the mentioned development also had strong impact on social and environmental aspects. As a consequence of the broad application of new technologies, the percentage of the agrarian working population diminished from almost $40 \%$ in 1895 to $2 \%$ in the first decade of the 21 st century (DBV, 2013, p. 20). Through the consolidation of agricultural production units, the overall number of agricultural enterprises decreased from more than 5.6 million around 1950 to fewer than 300,000 today (DBV, 2013, p. 19). Many young people have lost the opportunity to get into contact with agriculture through their parents' work. Furthermore, many agricultural production processes have become intransparent due to technical applications and are not visible anymore. Thus, an "alienation" of society and agriculture has and still is taking place, concerning large parts of society (von Alvensleben, 1998). 
This development has led to a decreasing agricultural literacy ${ }^{1}$ in industrialized countries. In this context, complaints have been made about a "generally agriculturally illiterate public" (Hubert, Frank, \& Igo, 2000, p. 526). Several studies illustrate that even simple agricultural facts are unknown to most children and adolescents and many misconceptions prevail (Brämer, 2010; Dillon et al., 2005; Kuhlemeier, van Den Bergh, \& Lagerweij, 1999; Mabie \& Baker, 1996; Trexler, 2000a). For instance, Mabie and Baker (1996) reported that most of 144 Californian fifth and sixth graders were not able to list three crops that are grown in their state. Among more than 3,000 German sixth and ninth graders, fewer than one third knew that hens cannot lay more than one egg a day and that cows are usually milked twice a day (Brämer, 2010).

In addition, the described historical agricultural change caused manifold environmental problems. The current agrarian land use influences the loss of biodiversity (BfN, 2010; Rockström et al., 2009). According to estimates of the Intergovernmental Panel on Climate Change (IPCC), agriculture causes approximately $13.5 \%$ of the worldwide greenhouse gas emissions caused by man (Pachauri \& Reisinger, 2007). These examples emphasize that without doubt an intensive, conventional agriculture does not harmonize with global sustainable development goals (Tilman et al., 2001; United Nations, 2012; more details are given in chapter 7.2).

The outlined environmental consequences of the structural change in agriculture illustrate that solutions for more sustainable agricultural practices will have to be pursued. The implementation will vastly depend on the next generations. Thus, the importance to reestablish the contact of children and youth to agriculture falls into place as a first step to make them agriculturally literate consumers, practitioners, policy- and decision-makers. Given this background, research and education highlight the need to confront students in institutional learning with current agricultural practices and their environmental impacts (Poudel et al., 2005; Trexler, 2000b).

\subsection{Curricular References to Agriculture}

The German school system is traditionally subdivided into four main types of school. The primary school comprises the first four years (in some federal states six years). From grade five onwards, there are three main secondary tracks. Hauptschule ends after year nine, and Realschule after year ten. Since recently, both tracks are combined in some federal states under the label secondary modern school. Gymnasium finishes after 12 or 13 years and is the only track that allows a direct access to university. Comprehensive schools comprise all academic levels.

${ }^{1}$ In compliance with other concepts such as scientific literacy (cf. Gräber, Nentwig, Koballa, \& Evans, 2002), the term agricultural literacy roughly defines a concept of basic agricultural education (Frick \& Kahler, 1991). 
In Germany, agriculture is anchored as a context of learning throughout all kinds of school and grade levels. Matz (2008) and more recently Bickel and Bögeholz (2013a) conducted systematic curricular analyses for agricultural content within the subjects geography, biology ${ }^{2}$ or equivalent subjects. The analysis of Matz (2008) comprised geography and biology curricula of all kinds of schools in five German federal states (as well as several Swiss cantons and Austria). Bickel and Bögeholz (2013a) extracted agricultural content within the national educational standards for biology and geography ${ }^{3}$ that represent guidelines for the implementation in all federal states. In addition, they analyzed curricula of both subjects concerning all secondary tracks in the federal state of Niedersachsen (Lower Saxony).

The national educational standards for biology mainly contain relations to agriculture in the area of decision-making competence. However, concrete agricultural topics are not suggested. The national educational standards for geography have links to agriculture in all three superordinate areas of competence (factual knowledge, decision-making, and competence to act). Similar to the national educational standards for biology, these links are rather vague and agriculture is only one optional context of application (Bickel \& Bögeholz, 2013a).

Concerning the analyzed curricula of the different federal states, a broad variety of agricultural content is mentioned. Across lower grades (up to grade 6), knowledge about farm animals and major agricultural crops (e.g., grain, potatoes) is accentuated as well as the production of food from animals and plants. As to higher grades, more specific agricultural aspects are mentioned such as distinct agricultural branches (e.g., arable farming, pasture farming) and agricultural models of economy (e.g., industrial livestock farming vs. adequate animal housing, organic farming). The aforementioned environmental impacts of modern agriculture (chapter 2.1) are rarely referred to, in particular relations to sustainable development goals are hardly to be found (for further reading see Bickel \& Bögeholz, 2013a; Matz, 2008).

Both studies conclude that throughout the analyzed standards, agriculture often only functions as a possible suggestion, an option, or a recommended topic to work on a given thematic complex (such as nature protection, globalization, or environmental ethics). Thus, the actual inclusion of agricultural content within biology and geography education to a large degree depends on the teacher (Bickel \& Bögeholz, 2013a; concerning past curricula see also Bischopink \& Brandes, 2002).

\footnotetext{
${ }^{2}$ Other subjects may also convey agricultural content. Geography and biology have the strongest bonds to agriculture, however.

3 There are no official national educational standards for geography. However, the German Society for Geography (Deutsche Gesellschaft für Geographie) has drafted a comprehensive work on national educational standards for geography that are referred to in Bickel and Bögeholz (2013a).
} 
Beyond curricular references for school subjects, agriculture provides an adequate context for the implementation of education for sustainable development. The interdisciplinary concept education for sustainable development has been proclaimed on the United Nations Conference on Environment and Development (United Nations, 1992) and ever since has been gaining an increasing importance in international educational contexts (Corcoran, Osano, Weakland, \& Hollingshead, 2009; de Haan, 2006; de Haan et al., 2008; Hopkins \& McKeown, 2002). Agriculture and in particular learning on farms adequately fits in this concept because it tackles one of the most basic human needs, namely food production, and addresses social, ecological, and economic dimensions (Bögeholz, 2005). In addition, it is directly related to many urgent environmental issues and to some of the UN millennium development goals such as fighting extreme poverty and hunger, saving biodiversity, and preventing a (further) climate change (Matz, 2008; United Nations, 2012; cf. chapter 7). However, to a large extent German secondary students do not seem to be aware of these interrelations (Fröhlich, Goldschmidt, \& Bogner, 2013; Menzel \& Bögeholz, 2009).

\subsection{Extracurricular Learning on School Farms}

The term farm education or farm-based education ("Lernen auf dem dem Bauernhof", cf. Schockemöhle, 2012) is neither protected nor properly defined. In this study, it refers to out-of-school learning on farms (that can be viewed as an type of outdoor education, cf. McComas, 2014; Morag, Tal, \& Rotem-Keren, 2013) and stands in contrast to more or purely cognitive learning about agriculture that predominates in academic contexts. Farms that provide educational activities are termed educational farms.

There is a multitude of different models of farm education. For some farms, education is only an additional income source. For others, educational activities are the core business and provide the major income. The offered activities can range from a one-hour guided farm tour up to a residential farm stay of several days (weeks) or involve repeated farm visits on a regular basis. The degree of the farm visitors' active participation also greatly differs as well as the target groups addressed. Most farm education programs center on children or adolescents, fewer address adults. Respective offers may be kindergartens on farms, manifold programs for school classes, or internships on farms (that are e.g., mandatory in Waldorf schools). Offers for adults mostly are seminars (e.g., about wine) on farms. Recently, models that connect consumers to local farmers have become more and more popular in Germany. Community-Supported-Agriculture $(\mathrm{CSA})^{4}$ is a locally-based economic model in this context. Consumers commit themselves to pay a certain amount of money for a fixed

\footnotetext{
4 In Germany, CSA is often referred to as "Solidarische Landwirtschaft". For further reading sea http://www.solidarische-landwirtschaft.org
} 
period of time and in exchange are provided with local food and they gain insight into or may even contribute to decision-making processes concerning the food grown. The farmer thus has a guaranteed income and gains independence of the market to some degree.

School farms are a prominent model of professional farm education in Germany that is central to the empirical part of this study. They host groups of children and adolescents-mostly school classes of grade three to six-for several days. Working in small groups of five to eight members, the participants are actively involved in the farmers' daily lives. Each group is supervised by a farm instructor (who may be a farmer or a teacher) and students may self-responsibly conduct tasks, whenever possible. The concrete jobs comprise a broad variety of agricultural routine jobs as well as craft and environmental activities, in particular during winter. The activities are designed to allow for a maximum of manual labor and active participation of the students. Thus, all processes of food production and processing are transparent and actively to be experienced (Bickel, 2006; Hübner, 2000; Schockemöhle, 2012). 


\section{Benefits of Farm Education and Related Approaches}

Educational farms have the primary aim to provide opportunities to learn about agriculture. However, the following section illustrates that the outcomes of farm education address various fields of learning.

The works of Krogh and Jolly $(2011,2012)$ present a theoretical foundation of the benefits of learning on farms. Since 1995, they have engaged in the Living School project in Norway, which comprises outdoor learning in school gardens as well as a close cooperation between local schools and neighboring farms. The core idea is that students regularly and actively participate on a local farm so that long-term connections to the farm can be established. The program starts in kindergarten and stretches over ten years in school with varying core topics in each year (Krogh \& Jolly, 2011).

According to Krogh and Jolly (2012), active participation in meaningful tasks is the key element of learning on farms. The tasks contain concrete, tangible goals that demand (and thus promote) control, discipline, patience, and perseverance. Thus, a range of favorable results can be achieved, such as

- Ability to act / mastering: The farm jobs demand the ability to make decisions and perseverance. The results of the tasks are self-explanatory and contribute to feelings of self-efficacy, empowerment, and competence (in the sense of selfdetermination theory; cf. Deci \& Moller, 2005 and 4.3.1).

- Motivation: The accomplishment of tasks acts as an incentive and encouragement to engage in and solve further tasks (indicating that the aspect mentioned before also affects motivation). By their engagement in farm jobs students can establish positive emotional and purposeful relationships to plants and animals that may be a motivational basis for wanting to learn more about and getting active concerning the environment.

- $\quad$ Ability to cooperate: Working together to reach one goal builds a common identity and strengthens the sense for social relatedness. Many tasks cannot be solved individually, thus participants can realize their own qualities and skills as well as those of others in order to reach the common goal (in the sense of cooperative learning, cf. Durlak, Weissberg, Dymnicki, Taylor, \& Schellinger, 2011; Eggert, Ostermeyer, Hasselhorn, \& Bögeholz, 2013).

- Knowledge building: The practical know-how gained by farm work is combined with factual learning concerning the production, processing, and use of animals, plants, and their products.

- Sense of coherence: All tasks in the garden and on the farms are framed in the path from field to fork and thus relate to a core need of human beings. (Krogh \& Jolly, 2012, pp. 6-7) 
Some of these favorable results were also mirrored by qualitative interviews with former students and accompanying teachers who partook in the Living School program (Krogh \& Jolly, 2011).

A further reason for the benefits of farm education is that the farm setting allows for several types of nature experiences (Bögeholz, 1999b, 2001, 2006). Central to farm education are instrumental nature experiences that combine the care for domesticated animals and plants with the overall aim to produce food and other commodities. Beyond, farm education allows for other types of nature experience, namely: scientific (exploring plants and animals, e.g., different grains), social (establishing a partnership with domesticated animals), ecological (examining ecosystems, e.g., soil testing), and aesthetic nature experiences (experiencing the beauty of nature, e.g., the smell of herbs, flowers) (Bögeholz, 1999b). Studies have shown that the frequency strongly correlates with the appreciation of nature experience $(r=.70-.86)$. In addition, the frequency of nature experiences influenced the intention to environmental action (Bögeholz, 1999b, 2006).

So far, there are only few empirical studies from the last decade that outline effects of farm education. It has to be noted that many of the analyzed studies remain on a descriptive level and only few of them deliver results gained by inferential statistical methods. Another limitation of most studies is the lack of control group data as well as of a repeated-measures design in order to point out real changes in the outcome variables. Against this background, most of the findings are rather tentative (Joshi, Azuma, \& Feenstra, 2008).

The presented overview comprises two review articles concerning possible effects of school gardens (Blair, 2009) and Farm to School programs ${ }^{5}$, respectively (Joshi, Azuma, \& Feenstra, 2008). In addition to the review findings, this section introduces recent empirical results and some theoretical-argumentative contributions. Particularly in the United States, there has been a considerable amount of studies on school gardens. Strictly speaking school gardens do not apply to the given definition of farm education; however, school garden activities are closely related to those on farms. For this reason, research findings on school garden programs are included in the subsequent section. The following section is structured according to the different outcomes.

\footnotetext{
${ }^{5}$ The Farm to School Network aims to establish local food sourcing and agricultural education in schools all over the United States. The program has a strong focus on healthy nutrition besides agricultural education. Similar to school gardening, the activities are mainly conducted in school. Since they are centered on food production, findings of Joshi et al. (2008) are included in this section.
} 
Knowledge, Learning, and Achievement. In the Netherlands, Haubenhofer et al. (2010) compared three different types of farm education concerning sixth graders' knowledge gains: a one day trip to a farm (1.5 hours), a one-week farm stay, and a "Farm School" program covering twenty days spent on a farm throughout a school year. Teacher evaluations suggested that the agriculture-related knowledge of the students grew with the duration of the program. However, a direct measure of children's knowledge was not applied.

Joshi et al. (2008) summarized 15 studies on outcomes of the Farm to School program in the United States. The authors suggested that participants of the program improved their knowledge about nutrition, and agricultural and garden produce. However, the reviewed studies had methodological limitations because most did neither consider control groups nor did they follow a rigorous evaluation design including inferential statistics.

In a more recent pre-post control study on the effect of garden-based education on sixth graders, students participating in the garden group increased the ability to correctly identify vegetables compared to a control group $(d=.48, p<.05$; Ratcliffe, Merrigan, Rogers, \& Goldberg, 2011). Studies that rest upon teacher evaluations or students' self-assessments agree with the notion that gardening and farming experiences can have a positive impact on science achievement in school (Blair, 2009; Smeds, Jeronen, Kurppa, \& Vieraankivi, 2011). Maybe this result can be explained by qualitative findings indicating that farm experiences promote social learning and strengthen the sense of self-efficacy (Blair, 2009; Krogh \& Jolly, 2012) that in turn can have a positive effect on learning and achievement in school.

Attitudes, Behavior, and Competence. In a literature review on possible benefits of school gardening, Blair (2009) concluded that students' general attitudes toward school improved with the amount of gardening activities. The same review and Ratcliffe et al. (2011) found that school gardening improved participants' preference for vegetables compared to a control group $(d=3.01, p<.05)$.

These attitudinal changes may also affect actual behavior. According to the mentioned literature reviews of Blair (2009) and Joshi et al. (2008) school gardening and Farm to School programs may improve fruit and vegetable consumption. Ratcliffe et al. (2011) found school gardening to increase students' willingness to taste vegetables $(d=.56, p<.001)$, and the frequency of vegetable consumption $(d=.40, p$ $<.01)$. However, these results have to be challenged because the improved nutrition behavior may be biased by an increased offer of fruits and vegetables. 
As outlined above, farm education offers various opportunities for many types of nature experiences (Bögeholz, 1999b; Bögeholz, 2001). Nature experiences are a fundamental basis for the (later) acquisition of Gestaltungskompetenz ${ }^{6}$ (Bögeholz, 2005) as the central aim of education for sustainable development (de Haan, 2006; de Haan et al., 2008). Agriculture is a central topic of sustainable development and is subject to various interrelations with other core issues such as the conservation of biodiversity, climate change, and Fair Trade (for further reading sea chapter 6 and Bögeholz, 2005; Matz, 2008; Tal, 2008). Farm education offers manifold opportunities for practical experiences concerning biodiversity and can thus contribute to the awareness for the conservation of biodiversity (cf. Article 13 of the Convention on Biodiversity; CBD, 1992). Besides, learners can develop their own values, notably concerning nutritional issues such as the consumption of meat (Bickel, 2006; Bögeholz, 2005). Concrete tasks comprising options for shaping land (e.g., a vegetable patch) as well as comparisons of realistic agricultural policy options (e.g., organic vs. conventional agriculture) allow participants in farm education to train their decisionmaking competence. As a result of the described process in farm education, the landscape and agriculture in general can be regarded from a more reflected point of view, and attitudes, behavioral options, and competences can be formed and fostered.

Recently, there has been a first study to support the outlined theoretical-deductive argumentation. Schockemöhle (2009) investigated the importance of hands-on activities in farm education of adolescents aged 13-16. Students' self-reports indicated an increased level of cognitive and affective components of "Gestaltungskompetenz" through the inclusion of instructional hands-on activities on farms in comparison to control group participants without hands-on $(d=.33, p<.05)$. However, the validity of self-reports as a measure for complex constructs such as "Gestaltungskompentenz" and other competences is a challenging task (Eggert \& Bögeholz, 2014).

Motivation and Interest. On a theoretical-argumentative level, studies describe motivational changes as positive results of farm and gardening education (Blair, 2009; Krogh \& Jolly, 2012). Empirical evidence in this field is rare, however.

Lekies and Sheavly (2007) scrutinized factors of a school garden project that influenced 9- and 10-year-old children's interest in gardening. Results showed that learned gardening skills predicted interest in gardening $(\beta=.39, p<.05$; Lekies \& Sheavly, 2007). Thus, the results advocate for the applicability of hands-on garden

\footnotetext{
${ }^{6}$ Gestaltungskompetenz is the central goal of ESD; it describes the ability to "modify and shape the future of society and to guide its social, economic, technological and ecological changes along the lines of sustainable development" (de Haan, 2006, p. 22).

${ }^{7}$ This comprises competences concerning interdisciplinary, networked, foresighted, and reflected thinking as well as empathy and solidarity (cf. Schockemöhle, 2009, p. 124).
} 
activities to foster gardening interest. However, changes in gardening interest after the treatment were not investigated due to the application of a posttest-only design.

Skinner and Chi (2012) reported that students' engagement ${ }^{8}$ in school garden activities predicted learning about gardening $(\beta=.27, p<.001)$ but also school grades in core subjects (mathematics, science, and social studies; $\beta=.32, p<.01$ ). Similarly, Fröhlich, Sellmann, and Bogner (2012) found that situational interest during a partly farm-based educational program on agriculture, nutrition, and consumerism correlates with the intention to practice an environmentally friendlier consumer behavior after the treatment $(r=.46)$. Even if both studies did not consider individual interest as a dependent variable, the findings emphasize the role of situational motivational variables during agriculture and garden education regarding other favorable effects.

In a nutshell, previous findings on the effects of farm education and related educational settings-and in particular respective hands-on experiences-suggest positive effects concerning

- attitudes towards, and

- knowledge about nature, agriculture and gardening,

- academic achievement,

- nutritional and social behavior,

- cognitive and affective components of "Gestaltungskompetenz", and

- motivational levels.

Yet, there is a lack of robust results based on rigorous evaluation designs. Among others, the assumption concerning positive motivational outcomes such as interest is yet only tentative and needs further empirical consideration.

8 The operationalization of engagement was similar to the conception of situational interest (cf. chapter 4.2). 


\section{Research on Interest and Interest Development}

In everyday speech, interest represents a preference for a particular object, however the scientific connotation of interest differs (Krapp \& Prenzel, 1992). But also definitions of central characteristics or components of interest slightly differ in various fields of interest research. The present research follows a pedagogic-psychological conception of interest as pointed out in 4.1. Furthermore, this study is based on a theoretical distinction of two constructs of interest (4.2). In the context of learning, the development of interests is one central aim as illustrated by models and theories (4.3). Prior research on agricultural interests will be outlined in 4.4 .

\subsection{The Conceptualization of Interest}

According to the person-object-theory of interest (e.g., Prenzel, Krapp, \& Schiefele, 1986; Schiefele, 1991), an interest describes a relational construct between an individual and a particular object. In this respect, „the individual, as a potential source of action, and the environment as the object of action, constitute a bipolar unit" (Krapp, 2007 , p. 8). Concrete actions between the individual and the object are referred to as object engagements. However, only some of the manifold object engagements in daily life may gradually develop into an individual interest through repeated occurrences. These interests may become stronger or weaker, or even vanish later (Hidi \& Renninger, 2006).

The object-specificity clearly distinguishes interest from other motivational variables (Krapp \& Prenzel, 2011; Krapp, 2007). The aim of interest-based actions is the engagement itself disregarding other connected or further aims (that would represent an extrinsic motivation for the engagement; Pekrun, 1988; Schiefele, 2009). An object of interest can be a concrete matter, a subject area or domain, an activity, or an abstract idea (Krapp, 2007).

As to the person-object-theory of interest (and many studies based on this conceptualization), interest involves two central components (e.g., Schiefele \& Krapp, 1996): i) an affective and ii) a value-based component. The affective component describes feelings of the individual while being engaged with the interest object. Thus, it operates on an unconscious, emotional level (Krapp, 2002b). The second, valuebased component is a rational regulation system and operates on a cognitive level (Krapp, 2005). It represents a conscious evaluation if the interest object is perceived as personally meaningful. Both components are inherently intrinsic and thus directly linked to the interest object and engagements with it, disregarding relations to other objects (Schiefele, 2009).

Some qualitative research approaches also consider knowledge as one component of interest (e.g., Renninger, Ewen, \& Lasher, 2002; Renninger, 2009). It is widely acknowledged, that there are tight relations between interest and knowledge 
(Alexander, Jetton, \& Kulikowich, 1995; Alexander, Kulikowich, \& Jetton, 1994; Alexander \& Jetton, 1996; Laukenmann et al., 2003; Schiefele, Krapp, \& Winteler, 2014; Schiefele \& Krapp, 1996; Tobias, 1994) and theories on interest development suppose that object-related knowledge grows with stabilized interest (Hidi \& Renninger, 2006; Renninger \& Hidi, 2011). However, most researchers conceptualize both constructs as separate from one another, because object-related knowledge may be predisposition and consequence of interest-based learning (Schiefele, 1996, 2009). Besides, recent studies have supported evidence that situational interest does not seem to have a linear relationship with knowledge (Rotgans \& Schmidt, 2014).

Not least for its connectedness to cognitive variables interest is considered a valuable learner characteristic that represents a prerequisite and at the same time a central aim of learning processes (Baumert et al., 1998; Voss \& Schauble, 2014). Besides the abovementioned interrelation of interest and knowledge, there is evidence that interest fosters academic achievement (Harackiewicz, Durik, Barron, LinnenbrinkGarcia, \& Tauer, 2008; Köller, Baumert, \& Schnabel, 2001; Köller, Trautwein, Lüdtke, \& Baumert, 2006; Randler, Khambari, Moses, Luan, \& Simsek, 2009; Wigfield \& Cambria, 2010), attention, goals, and levels of learning (for an overview see Hidi \& Renninger, 2006).

\subsection{Situational and Individual Interest}

Interest conceptions commonly distinguish situational from individual interest (Hidi \& Renninger, 2006; Krapp, 2002b; Schiefele, 2009). Situational interest is a fluent emotional state. It is bound to a concrete situation and represents the interestedness in the situation or the current activity. Due to this characteristic, it cannot persist over time per definition. Research has shown that situational interest involves focused attention, increased cognitive functioning, persistence, enjoyment or affective involvement, and curiosity (Schiefele, 2009). Stimulating and further maintaining situational interest is an immediate aim in instruction because it favors the process of learning and the motivational atmosphere in class (Hidi, Renninger, \& Krapp, 2004; Schiefele, 2009; Silvia, 2006). Since situational interest is usually triggered by environmental factors, instructional arrangements can directly address learners' situational interest (further details are given in 4.3.1).

In contrast, individual interest is a rather stable predisposition of an individual that persists over time (Krapp \& Prenzel, 1992). A manifest individual interest in a particular object entails an inner drive to repeatedly engage in this object (Hidi \& Renninger, 2006; Krapp \& Prenzel, 2011). According to the positive relations of interest and achievement mentioned above, individual interest is valued as a predisposition and an outcome of learning situations. However, due to its relative stability, it is not as easily and directly addressed in instruction as situational interest. 
Recent confirmatory factor analysis findings have demonstrated that situational and individual interest are correlated but constitute separate constructs (Linnenbrink-Garcia et al., 2010). Interrelations of situational and individual interest are reflected by some well-grounded models of interest development that will be presented in the following section.

\subsection{Theory on Interest Development}

Creating new and fostering existing interests is one central goal in biology education (Spörhase-Eichmann \& Ruppert, 2004). This aim is of particular significance with regard to the background of decreasing student interests in most school subjects during adolescence (Krapp, 1998; Löwe, 1987). Concerning the school subject biology, Löwe (1987) found a continual interest decline between the age of 8 and 18 .

Theoretic approaches towards the development of interest base on the distinction of situational and individual interest. Concerning the former, the model of situational interest (Mitchell, 1993) scrutinizes factors that trigger and maintain situational interest as outlined in 4.3.1. The four-phase model of interest development (Hidi \& Renninger, 2006) illustrates how situational interest may favor the development of individual interest (4.3.2).

\subsubsection{Conditions to Promote Situational Interest}

In the context of mathematics, Mitchell (1993) developed a model of situational interest. The model is based on the assumption that the appearance and the further maintenance of situational interest are determined by different classroom conditions. The study proposes a multifaceted construct of situational interest that takes into consideration conditions to spark situational interest (catch) and conditions to keep it alive (hold).

The study extracted catch- and hold-facets from students' answers to open-ended questionnaires. Identified catch conditions were social and cognitive stimuli. Group work was recognized as a social stimulus, whereas computers and puzzles appeared to be cognitively stimulating to students. Hold conditions were meaningfulness and involvement. Content that was perceived as personally meaningful with relevance to the learners' life had the potential to preserve the students' interest as well as active participation in the learning process. The extracted catch- and hold-facets were tested and validated in a subsequent quantitative survey by means of factor analysis and path diagram.

A systematic research approach that applies all of Mitchell's extracted catch- and hold-facets to other interest domains has been lacking so far. Yet, several empirical studies provided further evidence for some of Mitchell's and other catch and hold facets. Some scholars have applied visual stimuli in working materials to trigger 
situational interest in computer-based learning in mathematics (Durik \& Harackiewicz, 2007; Magner, Schwonke, Aleven, Popescu, \& Renkl, 2014), psychology, and the arts (Silvia, 2005a, 2010). Novelty of a given learning context was suggested as a cognitive catch in physical and science education (Chen, 1999; Dohn, 2011a, 2013; Zhu, 2014).

As to hold elements, qualitative (Dohn, 2011a, 2011b, 2013; Palmer, 2004, 2009) as well as quantitative studies in science education (Hummel, Glück, Jürgens, Weisshaar, \& Randler, 2012; Swarat, Ortony, \& Revelle, 2012) confirmed the influence of active involvement for situational interest. Hulleman, Godes, Hendricks, and Harackiewicz (2010) manipulated perceived meaningfulness in the mathematics classroom and found a main effect on situational interest. More details concerning sources of situational interest as well as catch- and hold-elements are given in chapter 9.2.3.

Besides the instructional factors mentioned, the individual evaluation of the learning environment is of importance for situational interest. Sansone and Thoman (2005, p. 507) suggested that "context affects learners through their own lens". Thus, a given learning environment can impact learners in different ways due to their individual response. For instance, Holstermann, Grube, and Bögeholz (2010) supported evidence that hands-on experiences do not per se increase interest but the perceived quality of the experience moderates the effect.

In this regard, the perception of autonomy, competence, and social relatedness according to self-determination theory (Deci \& Ryan, 1993; Deci, Vallerand, Pelletier, \& Ryan, 1991) appear to influence motivational levels such as situational interest (e.g., Kunter, Baumert, \& Köller, 2007; Minnaert, Boekaerts, \& de Brabander, 2007).

The need for autonomy describes the will to act independently in concrete activities and to determine the course of action as well as its goals. Thus, coherence of the action with the individual and its personal wishes and goals fosters the experience of autonomy. Instructional conditions that allow for a real choice regards content and implementation as well as careful instructor behavior ensuring that participants understand and know how to implement a given task are known to strengthen the need for autonomy. In contrast, controlling teacher behavior and excessive choice options undermine autonomy (Katz \& Assor, 2007). The need for competence refers to the experience of one's own effectiveness and the ability to successfully solve tasks. Instruction that offers optimally challenging tasks within the learners' reach supports competence fulfillment as well as clear and well-structured tasks (Deci \& Moller, 2005; Urdan \& Turner, 2005). The need for social relatedness characterizes the desire to be connected to others and to experience satisfying social contacts. In learning contexts, social relatedness becomes apparent between the learner and the instructor as well as in-between learners (Deci, 1998; Furrer \& Skinner, 2003). 
Several studies proved that all of the three needs are positively related to situational interest across various domains of learning. More information regarding the influence of perceived autonomy, competence, and social relatedness on situational interest is given in chapter 0 .

Further theoretical contributions on interest development have expanded the distinction between two phases of situational interest to the process of the development from situational to individual interest as illustrated by the following paragraph.

\subsubsection{The Development of Individual Interest}

Perpetuating Mitchell's differentiation between two phases of situational interest, (Krapp, 2002b) elaborated on the transition from situational to individual interest. He proposed a model that included two "ontogenetic steps" (Krapp, 2002b, p. 399) of interest development. Firstly, the shift from the initial occurrence (catch-phase) towards a stabilized situational interest (hold-phase); secondly, the change from situational interest towards a more or less enduring individual interest.

Following Krapp's model, Hidi and Renninger (2006) further distinguished two phases of individual interest. Their four-phase model of interest development is based on the idea that concrete actions may arouse situational interest that in turn may encourage the emergence or consolidation of an individual interest (Hidi \& Renninger, 2006). The model distinguishes between four phases, namely triggered situational interest, maintained situational interest, emerging individual interest, and welldeveloped individual interest.

Triggered situational interest is almost equivalent to Mitchell's catch phase. A different terminology is chosen on purpose because "triggering interest describes an initial beginning phase of the psychological state of interest [...]. On the other hand, catching interest suggests that the interest that individuals already experience is being diverted towards the situation" (Hidi, 2000, p. 313). It includes short-term changes in affective and cognitive processing (Hidi \& Baird, 1986, 1988) and is usually but not necessarily externally initiated.

Maintained situational interest equals Mitchell's hold phase and represents a subsequent state to triggered situational interest over an extended period of time. It comprises the learners' focused attention and persistence over an expanded time span. Just as the first phase, it is typically but not necessarily externally activated (Hidi \& Renninger, 2006).

Emerging individual interest is featured by positive emotions as well as stored value and knowledge (Hidi \& Renninger, 2006; Renninger, 2000). It describes a personal tendency to engage oneself in tasks related to the interest object of one's own accord even if external triggers are lacking. Students with an emerging individual interest often 
redefine or exceed given task demands and show a great effort and creativity in their work (Lipstein \& Renninger, 2007; Renninger \& Hidi, 2002).

A well-developed individual interest is similar to the preliminary phase of emerging individual interest. It also refers to positive feelings but greater levels of stored value and knowledge about the interest object (Renninger \& Hidi, 2011). Learners appreciate opportunities to engage in interest-based activities. A well-developed interest produces "effort that feels effortless" (Hidi \& Renninger, 2006, p. 115).

The model suggests that the process of interest development occurs through repeated object engagements (Hidi \& Renninger, 2006). Taking this background into consideration, research has suggested including sequenced interventions in order to consolidate individual interest in the long run (Holstermann, Ainley, Grube, Roick, \& Bögeholz, 2012).

The four-phase model is an important reference work for further studies on (particularly individual) interest development. To avoid any misinterpretation it has to be emphasized that the described four phases should not be considered a logical chain of one altering type of interest. In fact, the fundamental difference between situational and individual interest has to be emphasized. The former represents a transient motivational state and the latter a personal more or less enduring predisposition. Insofar, a situational interest cannot grow or transform into an individual interest but can only promote its emergence or development. In addition, it has to be noted that the process from a first situational interest to a well-developed individual interest is not necessarily linear. Recent findings suggested a reciprocal reinforcement of situational and individual interest (Linnenbrink-Garcia et al., 2010), as will be further explained in chapter 9. To better understand interactions between both types of interest-and in particular the role of a pre-existing individual interest on situational interest in a current engagement-researchers call for more empirical evidence (Renninger \& Hidi, 2011).

Of course, there are several other factors besides situational interest that may foster individual interest. Influence factors of individual interest in agriculture have not been studied yet. However, potential influence factors may be derived from research concerning other interest objects. According to findings across many different domains, there seems to be a general influence of prior knowledge on interest (e.g., Alexander et al., 1995; Tobias, 1994). Disgust sensitivity_being a lasting predisposition in response to certain stimuli (Izard, 1977) - has been found to be a negative influence on interest in biological topics (e.g., during a biology dissection class; Holstermann et al., 2012). Taking for granted that agriculture comprises some potential disgust triggers (e.g., animal feces, dirt, barn smell; Bixler \& Floyd, 1997), a negative influence of disgust sensitivity on agricultural interest appears to be likely. Research in nature-related interest proved a positive relation between interest and nature experience (Cheng \& Monroe, 2012; Leske \& Bögeholz, 2008). Such a relation might also apply to 
agricultural contexts. More details on these potential influence factors and how they actually relate to interest in agriculture and its content areas are given in chapter 7 .

\subsection{Research on Agricultural Interests}

Agriculture comprises a broad and multi-facetted content area (cf. chapter 2). It stretches out over typical science topics (e.g., domestic animals and plants), technical issues (application of machines), and may also involve economic, social, and ecological issues.

To date, research has hardly tackled agricultural interests. The international research project Relevance of Science Education (ROSE) investigated 10th graders' interests in science and technology across several European and non-European countries. The survey comprised 108 items about students' science interests, among which three referred to agricultural content (benefits and hazards of modern farming, organic farming, and how to improve harvests; e.g., Jenkins \& Pell, 2006). In a German sample as well as among participants from England, Norway, and Sweden the items with agricultural content were rated among the least interesting ones (Holstermann \& Bögeholz, 2007; Jenkins \& Pell, 2006; Jidesjö, 2008).

Lately, a representative survey inquired agricultural interest across the German population above the age of 14 years (TNS Emnid, 2012). The single item measure asked for an interest in agricultural content without further differentiation. The results illustrated that older participants are more interested in agriculture compared to younger participants. Across participants in the youngest age group (14 - 29 years), only $23 \%$ indicated high or very high rates of interest in agriculture in contrast to $60 \%$ in the group of participants above 60 years.

In sum, the studies did not incorporate the different content areas that agriculture embraces. Second, the studies involved individuals aged 14 and above and cannot give information concerning agricultural interests of younger individuals. Third, methodological concerns have to be raised because a single-item measure was applied (cf. Liu, 2004; Loo, 2002; Oshagbemi, 1999) that did not base on theoretical conceptions of the interest construct (cf. Schiefele, 2009). To generate thorough information concerning agricultural interests, the mentioned limitations of the existent studies should be considered in further research. Because an instrument to measure interest in different agricultural content areas did not yet exist, this was the starting point for the present thesis.

Research in related domains suggested a gender-specificity within some agricultural content areas. In this regard, studies have found girls to be more interested in animals than boys (e.g., Finke, 1999). In contrast, boys indicate higher interest rates in technological aspects (e.g., Schreiner, 2006), which might also apply to the agricultural context. 


\section{Objectives}

Building on the outlined theoretical background, this study investigated agricultural interests of fifth and sixth grade students. The study pursued the following objectives that are illustrated in Figure 5.1.

\section{i) Developing a Measurement Instrument for Agricultural Interests}

Because prior studies lacked a systematic approach to measure agricultural interest(s), the first objective was to develop a valid and reliable measurement instrument of agricultural interests. The instrument considered theoretical conceptualizations concerning the individual interest construct (e.g., Schiefele, 2009). Moreover, it included fundamental agricultural content areas that are coherent with fifth and sixth graders conceptions of agriculture (e.g., Fröhlich et al., 2013; Rubenstein, 2010). Chapter 6 and 7 display how the instrument was developed and validated.

\section{ii) Explaining Agricultural Interests}

The second objective considered determinants of students' content specific agricultural interests. The choice of potential influence factors grounded on prior empirical interest research. Prior knowledge is a common predictor for interest across various domains (e.g., Alexander et al., 1995). Gender has been found to influence particularly agriculture-related interests (e.g., Jones, Howe, \& Rua, 2000). Disgust sensitivity and nature experiences appear to be associated with interest in nature-related contexts (e.g., Bixler \& Floyd, 1997; Chawla \& Cushing, 2007; Leske \& Bögeholz, 2008). Thus, gender, agriculture-related disgust sensitivity, previous agriculture-related nature experiences (on farms, in gardens, and with pets), and prior knowledge were considered as predictors of agricultural interests. Chapter 7 documents the respective results. Chapter 8 gives further insights into the gender-specificity within agricultural interests.

\section{iii) Increasing Agricultural Interest through Extracurricular and Curricular Interventions}

Previous research on outcomes of farm education programs has hardly considered motivational variables. Thus, the third objective was to evaluate the effect of a five-day intervention on a school farm that centered on participants' active involvement in basic farm works regarding students' agricultural interests. To learn about the development of agricultural interest subsequent to the school farm stay, a second consecutive intervention was conducted in school to maintain the increased interest level after the school farm stay (cf. Hidi \& Renninger, 2006; Holstermann et al., 2012).

The empirical studies in chapter 8 and 9 present the effects of the educational interventions on the development of agricultural interests. 
iv) Conditions to Promote Situational Interest in the Agricultural Interventions

Interest theory suggests that increases in individual interest after educational interventions are mediated by situational interest in the interventions (Hidi \& Renninger, 2006). Thus, conditions that promoted situational interest were scrutinized during both educational interventions. The basic needs according to self-determination theory (autonomy, competence, social relatedness; cf. Deci \& Ryan, 1985, 2000; Deci, 1998) were thought to predict situational interest on the school farm. Building on Mitchell's (1993) model of situational interest, it was investigated whether different variants of the learning unit in school-that was conducted as second intervention-resulted in varying levels of situational interest. Three variants were applied with catch-only, holdonly, and combined catch- and hold elements. The respective results are presented in chapter 9.

\section{v) The Interplay between Situational and Individual Interest in Agricultural Learning}

The last objective was to advance the understanding of interrelations between situational and individual interest during the process of interest development in agricultural learning (cf. Renninger \& Hidi, 2011). The interrelations were analyzed in a research design with two consecutive interventions on a school farm and in schoolaccompanied by a measure of situational interest each-and four measures of individual interest. A reciprocal reinforcement of situational and individual interest was postulated (Linnenbrink-Garcia et al., 2010). The empirical study in chapter 9 deals with this issue.

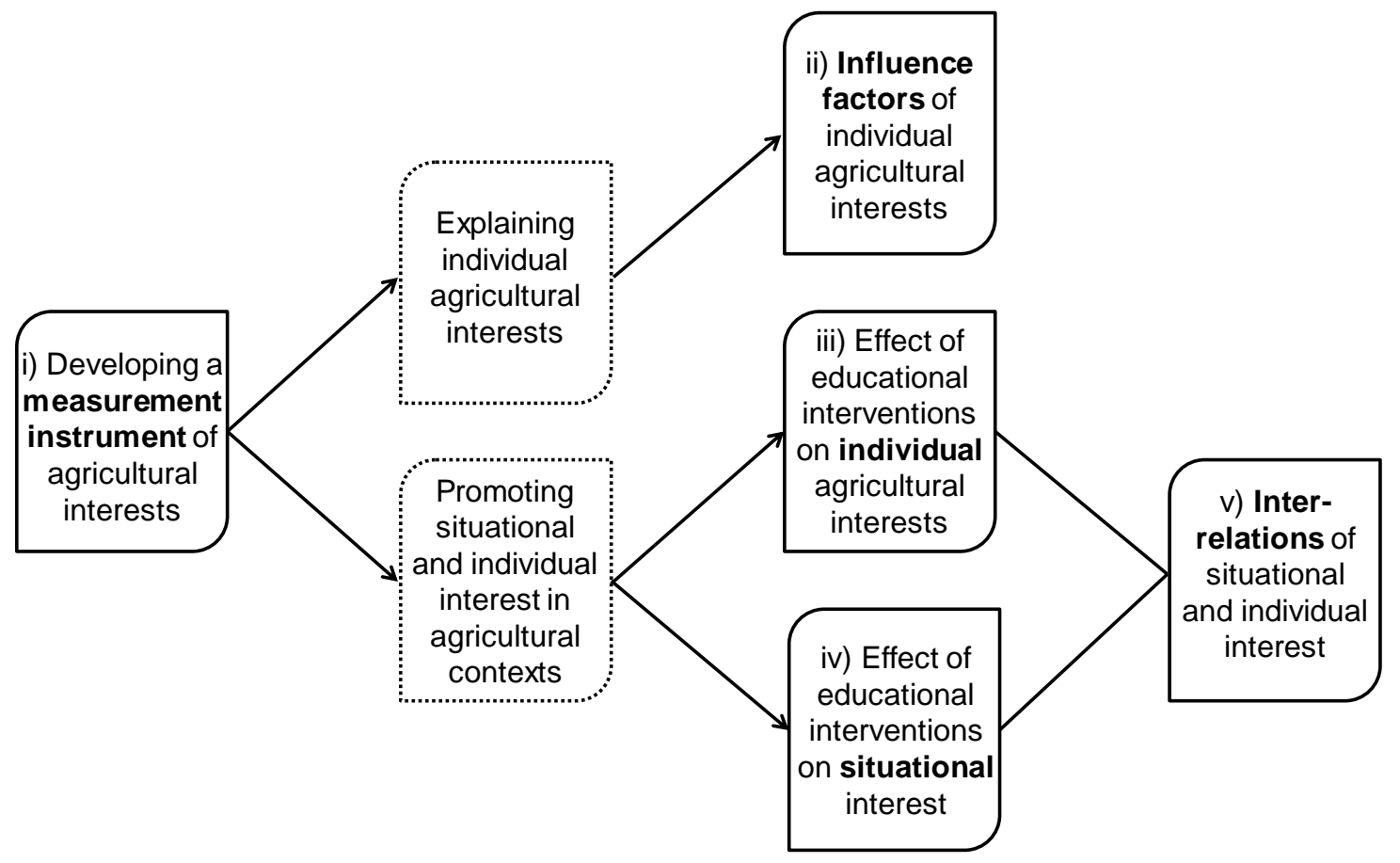

Figure 5.1: Core objectives of the present thesis 


\section{Schülerinteressen an landwirtschaftlichen Themen ${ }^{9}$}

\subsection{Hintergrund und Problemstellung}

Landwirtschaft nimmt als eine Art der Landnutzung-wie auch Forstwirtschaft-eine zentrale Rolle für die Gestaltung nachhaltiger Entwicklungen ein. Die landwirtschaftliche Produktionsweise steht im Zusammenhang mit vielen globalen Umweltproblemen. Zu nennen wären hier beispielsweise der Verlust von Biodiversität und der Themenkomplex Klimawandel.

Heutzutage haben Heranwachsende wenig reale Bezüge zur Landwirtschaft und zur landwirtschaftlichen Produktion von Lebensmitteln. Damit einher geht ein Verlust des erfahrungsbasierten Wissens über Landwirtschaft. Um Wissen über Landwirtschaft und die Zusammenhänge von landwirtschaftlicher Produktion mit (nicht) nachhaltigen Entwicklungen künftig in der Gesellschaft zu verankern, bedarf es einer landwirtschaftsbezogenen Bildung für nachhaltige Entwicklung. Für eine Integration und Vernetzung landwirtschaftsbezogenen Wissens beim Kompetenzaufbau mit Blick auf die Gestaltung von nachhaltigen Entwicklungen („Gestaltungskompetenz“, de Haan et al., 2008), erscheint ein Interesse an landwirtschaftsbezogenen Themen förderlich. Forschung konnte in verschiedenen Studien zeigen, dass Interesse eine bedeutende Voraussetzung für erfolgreiche Lernprozesse darstellt (für eine Übersicht siehe Hidi \& Renninger, 2006). Vor diesem Hintergrund ist die Entwicklung von Interessen an landwirtschaftlichen Themen ein explizites Ziel des außerschulischen Lernorts Bauernhof. Insbesondere kann eine Interessenentwicklung im Rahmen von langzeitpädagogischen Maßnahmen (Randler \& Bogner, 2007) gefördert werden, somit bieten einwöchige Schulbauernhofaufenthalte ideale Bedingungen für eine Interessenförderung an landwirtschaftlichen Themen.

Bislang fehlt jedoch ein Instrument zur Überprüfung, inwiefern eine Entwicklung von Schülerinteressen an landwirtschaftlichen Themen durch (längerfristige) Bauernhofaufenthalte gelingt. An diesem Forschungsdesiderat setzt unser empirischer Beitrag an. Zuvor möchten wir jedoch die Zusammenhänge von Landwirtschaft und nachhaltiger Entwicklung sowie die Folgen des landwirtschaftlichen Strukturwandels mit Blick auf die Beziehung junger Menschen zur Landwirtschaft vertiefen. Es folgen Ausführungen zum außerschulischen Lernort Bauernhof und zu zentralen Aspekten der Interessenforschung bevor die Stichprobe und die entwickelten Messinstrumente für landwirtschaftsbezogene Schülerinteressen (Kapitel 6.2) vorgestellt werden. Letzteres wird genutzt, um diesbezügliche individuelle Interessen von Schülerinnen

9 Source: Bickel, M., \& Bögeholz, S. (2013). Schülerinteressen an landwirtschaftlichen Themen [Pupils' interests in agricultural topics]. In J. Friedrich, A. Halsband, \& L. Minkmar (Eds.), Biodiversity and Society. Societal dimensions of the conservation and utilization of biological diversity (pp. 59-72). Göttingen: Universitätsverlag Göttingen. 
und Schülern zu analysieren (Kapitel 6.3), bevor die Ergebnisse diskutiert werden und wir einen kurzen Ausblick geben (Kapitel 6.4).

\section{Landwirtschaft und Nachhaltige Entwicklung}

Viele bedeutende Themen, die im Kontext nachhaltiger Entwicklung diskutiert werden, stehen im unmittelbaren Zusammenhang mit der Landwirtschaft. Ein solches Thema ist der weltweite Verlust der Biodiversität. Biodiversität ist eine tragende Säule für die dynamische Stabilität unseres Planeten und die globale Ernährungssicherheit (Nellemann \& Corcoran, 2010). Eine der größten Bedrohungen der Biodiversität ist die gegenwärtig mehrheitlich praktizierte Form der Landwirtschaft (BfN, 2010; MEA, 2005; Rockström et al., 2009; Sala et al., 2000). Durch die weltweite Ausweitung kultivierter Flächen, hat die landwirtschaftliche Landnutzung unmittelbare Folgen für die lokale und globale Biodiversität (MEA, 2005). Die Veränderung natürlicher und naturnaher Habitate geht mit einem hohen Verlust dort vorkommender Organismen einher. Die biologische Diversität ist in zahlreichen bewirtschafteten Systemen (stark) rückläufig. Das gilt für die sogenannte geplante wie auch für die assoziierte Biodiversität (IÖW, Öko-Institut e.V., Schweisfurth-Stiftung, Freie Universität Berlin, \& Landesanstalt für Großschutzgebiete, 2004). Erstere bezieht sich auf alle Lebewesen, die bewusst für die Erzeugung von Produkten in das System integriert werden (z.B. Nutzpflanzen, tiere) oder die eine erwünschte ökologische Funktion einnehmen (z.B. durch Unterdrückung eines Pathogens). Assoziierte Biodiversität umfasst weitere Lebewesen, die das System besiedeln (etwa Bodenorganismen, Wildkräuter).

Der landwirtschaftsinduzierte Biodiversitätsverlust wird nicht ausschließlich durch die Transformation eines natürlichen bzw. naturnahen Habitats in eine landwirtschaftlich genutzte Fläche verursacht. Entscheidend ist auch wie die Landbewirtschaftung erfolgt. Intensivierung, Rationalisierung, Spezialisierung und Konzentration kennzeichnen die industrialisierte Landwirtschaft (BfN, 2010). Im Einzelnen müssen folgende Faktoren in den Blick genommen werden (nach BfN, 2010; Ellenberg \& Leuschner, 2010; FAO, 2007; Geiger et al., 2010; Liess et al., 2005; MEA, 2005):

- Pestizideinsatz und übermäßige Stickstoff- und Phosphordüngung sowie daraus resultierende Eutrophierung der Landschaft,

- verengte Fruchtfolgen und Flächenzusammenlegungen (Flurbereinigung),

- Angleichung der Anbausysteme,

- Einsatz von wenigen Hochleistungssorten,

- exzessiver Wasserverbrauch (Bewässerung),

- Überweidung und Massenproduktion. 
Diese Zusammenstellung vermittelt einen Eindruck über Zielkonflikte, die zwischen einer intensiven Landwirtschaft und einer nachhaltigen Nutzung der biologischen Vielfalt bestehen. Weiteres Thema im Spannungsfeld von (intensiver) Landwirtschaft und nachhaltiger Entwicklung ist beispielsweise der Einsatz gentechnisch veränderter Organismen (GVO). Darüber hinaus ist für die Diskussion um Landnutzung und die Umsetzung des Leitbildes der nachhaltigen Entwicklung der Themenkomplex Klimawandel zentral.

\section{Folgen des landwirtschaftlichen Strukturwandels}

Der Strukturwandel hat den landwirtschaftlichen Sektor grundlegend verändert. Die Technisierung der Produktionsprozesse ersetzte viele manuelle und körperliche Tätigkeiten. 1950 waren 25\% der arbeitenden Bevölkerung in Deutschland im Primärsektor ${ }^{10}$ beschäftigt (Statistisches Bundesamt, 2011). Dementsprechend lebten viele Kinder auf Bauernhöfen und Landwirtschaft war ein integraler Bestandteil des alltäglichen Lebens. Heute sind nur noch ca. $2 \%$ der Erwerbstätigen im Primärsektor tätig (ebd.). Die Zusammenlegung von Produktionseinheiten führte zu einer drastischen Abnahme landwirtschaftlicher Betriebe ${ }^{11}$. Als Konsequenz ist die Produktionskapazität des Einzelbetriebs deutlich gestiegen. In Folge der Intensivierung und Produktivitätssteigerung sind landwirtschaftliche Produktionsprozesse intransparenter geworden. Während Kinder und Jugendliche früher viele von Hand ausgeführte Arbeitsschritte beobachten oder an innen mitwirken konnten (oder mussten), werden diese heute häufig maschinell ausgeführt. Sie sind damit nicht einsehbar und auch nicht unmittelbar (be-)greifbar.

Der Strukturwandel in der Landwirtschaft hat ohne Zweifel (zumindest kurzfristig) auch deutliche Vorteile mit sich gebracht, insbesondere durch den Produktivitätsanstieg. Die beschriebene Entwicklung hat aber auch zu einer zunehmenden Entfremdung großer Bevölkerungsteile vom landwirtschaftlichen Geschehen geführt.

\section{Der außerschulische Lernort Bauernhof}

Eine landwirtschaftliche Grundbildung (agricultural literacy, Frick \& Kahler, 1991) ist bereits in frühen Stadien des Bildungswegs sinnvoll (Hubert et al., 2000). Da selbst einfache landwirtschaftliche Zusammenhänge vielen Kindern und Jugendlichen unbekannt sind (Brämer, 2010), sollten schon möglichst früh Bildungsangebote zur Landwirtschaft gemacht werden.

10 Primärsektor wird hier im engen Verständnis des Begriffs bezogen auf die Sektoren Land-, Forstwirtschaft und Fischerei verwendet. Eine weitere Interpretation des Begriffes beinhaltet alle Wirtschaftssektoren, die Rohmaterialien verwenden oder bereitstellen (z.B. Bergbau).

${ }^{11}$ Die Anzahl landwirtschaftlicher Betriebe hat sich von 1.646.750 in 1949 auf nur noch 301.000 in 2010 reduziert (DBV, 2011). Der Arbeitskräftebesatz sank in diesem Zeitraum von 30 Arbeitskräften pro 100 ha auf 3,3 (ebd.). 
Entsprechend der aufgeführten Verflechtungen von Landwirtschaft und nachhaltiger Entwicklung (inklusive Schutz und nachhaltige Nutzung der Biodiversität), haben Bauernhöfe ein großes Potential für die Umsetzung einer Bildung für nachhaltige Entwicklung (Bögeholz, 2005; Schockemöhle, 2009). Derartige Bildungsangebote und konzepte werden unter den Stichworten Lernort Bauernhof oder Lernen auf dem Bauernhof zusammengefasst (Schockemöhle, 2012). Die Konzepte und Angebotsinhalte sowie deren zeitlicher Umfang differieren jedoch stark wie auch die Ziele und der Grad der Eigentätigkeit der Teilnehmenden. Ein Ziel des Lernorts Bauernhof ist es, über die unmittelbare Erfahrung ein Interesse an Landwirtschaft zu wecken. Ob dies jedoch gelingt, wurde wissenschaftlich bisher nicht untersucht.

\section{Schülerinteressen an landwirtschaftlichen Themen}

Bisher gibt es kaum Erkenntnisse zu (Schüler-)Interessen an Landwirtschaft. Ergebnisse von Holstermann und Bögeholz (2007) spiegeln ein sehr geringes Interesse von Schülerinnen und Schülern der zehnten Jahrgangstufe an landwirtschaftlichen Aspekten wider. Andere Studien zeigen, dass ein Interesse an Natur die Handlungsbereitschaft stärkt, Biodiversität zu schützen (Leske \& Bögeholz, 2008). Diese Befunde unterstreichen die Bedeutung einer profunden Untersuchung landwirtschaftsbezogener Interessen und deren Fördermöglichkeiten im (außer-) schulischen Kontext.

Aus bildungswissenschaftlicher Perspektive hat Interesse im Allgemeinen die Funktion, Lernprozesse zu initiieren und qualitativ zu verbessern. In der pädagogischpsychologischen Forschung wird Interesse als Voraussetzung sowie Ergebnis guter Lernprozesse betrachtet (Krapp, 1998). Interesse ist ein Phänomen, das aus der Interaktion eines Individuums mit seiner sozialen und institutionellen Umwelt entsteht. Im Gegensatz zu Motivation ist Interesse objektspezifisch. Es gibt also nicht den Zustand einer allgemeinen Interessiertheit, ohne dass das Interesse auf ein bestimmtes Objekt gerichtet ist (Schiefele, 2009). Ein Interessenobjekt kann ein konkreter Gegenstand, eine Tätigkeit oder auch ein Themengebiet sein. In theoretischen Diskursen wird zwischen situationalem und individuellem Interesse unterschieden (Krapp \& Prenzel, 2011). Ersteres ist an eine konkrete Situation gebunden, bezieht sich auf ein gegenwärtiges Ereignis oder eine Tätigkeit und hält dementsprechend nur für die Dauer dieser Situation an. Das erste Auftreten dieser Interessensform ist in der Regel extern stimuliert, z.B. durch ein Lernangebot. Solch eine spezifische motivationale Qualität einer Lernsituation wird als individuell wahrgenommene Interessantheit eines Objekts verstanden (Krapp \& Prenzel, 2011). Das (wiederholte) Auftreten von situationalem Interesse kann die Entwicklung eines länger anhaltenden individuellen Interesses begünstigen (Hidi \& Renninger, 2006). Individuelles oder persönliches Interesse ist ein relativ stabiler Teil der motivationalen Grundstruktur einer Person. Es wird als dispositionale Charaktereigenschaft eines Individuums betrachtet. Die Interessensbeziehung zu einem Objekt beinhaltet kognitive 
und affektive Komponenten (Hidi et al., 2004). Sie repräsentieren auf das Interessenobjekt bezogene Wertzuschreibungen und Gefühle. Ein Individuum erachtet somit ein Interessenobjekt als persönlich bedeutsam und erlebt während einer interessensbasierten Aktion positive Gefühle. Beide Komponenten sind intrinsischer Natur, sie resultieren also ausschließlich aus der interessensbasierten Aktion bzw. dem Interessengegenstand selbst.

Im landwirtschaftlichen Kontext kann individuelles Interesse z.B. für das Melken von Kühen (Tätigkeit), eine bestimmte Landmaschine (Gegenstand) oder Ackerbau im Allgemeinen bestehen (Gegenstandsbereich). Situationales Interesse tritt per Definition während einer konkreten Handlung auf, z.B. beim Melken von Kühen, bei der Beobachtung einer Maschine oder beim Getreide säen. Dieses Beispiel verdeutlicht, dass situationales Interesse - eine konkrete, reale Tätigkeit oder Situation, wie das beschriebene Melken - ein andauerndes individuelles Interesse auslösen bzw. verstärken kann (z.B. an Tieren / Tierhaltung im Allgemeinen). Da bisher keine umfassenden Befunde zum landwirtschaftsbezogenen Interesse und diesbezüglicher Messinstrumente vorliegen, zielt unsere Studie auf i) die Entwicklung valider und reliabler Instrumente zur Messung von landwirtschaftsbezogenen individuellen und situationalen Interessen sowie auf ii) die Gewinnung erster Ergebnisse zu individuellen landwirtschaftsbezogenen Schülerinteressen ab. Neben ersten inhaltlichen Erkenntnissen soll damit ein Beitrag für zukünftige Evaluationsstudien zum Interesse an und in landwirtschaftlichen Kontexten geleistet werden.

\subsection{Methodische Vorgehensweise zur Erhebung der Schülerinteressen}

Dem Beitrag liegt eine Fragebogenuntersuchung zu Grunde, an der 115 Schülerinnen und Schüler (davon 59 Mädchen) der fünften und sechsten Jahrgangsstufe teilnahmen (Gymnasium: $n=75$; Realschule: $n=40$ ). Die Befragung wurde im Anschluss an einen einwöchigen Schulbauernhofaufenthalt durchgeführt. Zwei Realschulklassen aus Baden-Württemberg wurden unmittelbar auf dem Schulbauernhof befragt und drei Gymnasialklassen kurz nach ihrem Schulbauernhofaufenthalt in ihrer Hamburger Schule.

\subsubsection{Messung der individuellen landwirtschaftsbezogenen Interessen}

Das individuelle Interesse wurde für die fünf elementaren landwirtschaftlichen Bereiche Tierhaltung, Ackerbau, Gemüse- und Obstbau, primäre Lebensmittelverarbeitung und Landtechnik gemessen. Diese Operationalisierung beinhaltet Bereiche, die dem Verständnis von Schülerinnen und Schülern der fünften und sechsten Jahrgangsstufe gerecht werden. Die Skala zur Messung des individuellen Interesses wurde aufbauend auf Schiefele und Krapp (1996) entwickelt. Jeder der fünf Themenbereiche wurde über sechs Items erhoben. Von diesen beinhalten drei gefühlsbezogene und drei wertbezogene Valenzen (vgl. Hidi et al., 2004). 
Eine erste explorative Faktorenanalyse zeigte, dass sich gefühls- und wertbezogene Valenzen empirisch nicht als zwei Subskalen der Gesamtskala Interesse an Landwirtschaft herauskristallisieren (vgl. auch Schiefele, 1990b; Schiefele \& Krapp, 1996). Jedoch zeigte sich beim Einbezug maximal vieler Items eine inhaltliche Differenzierung der landwirtschaftsbezogenen Themenbereiche in einer 4Faktorenstruktur (die die beiden pflanzenbaulichen Themenbereiche zusammenlegt) mit einer kumulierten Varianzaufklärung von $74 \%$.

Mit dem Ziel einer effizienten und zeitökonomischen Messung der Schülerinteressen, identifizierten wir anschließend im Rahmen der Skalenbildung vier zentrale Items für jeden der einzelnen fünf landwirtschaftlichen Themenbereiche. Eine zweite explorative Faktorenanalyse mit den verbleibenden 20 Items spricht für eine sehr gute Konstruktvalidität: Empirisch kristallisierte sich eine 5-Faktoren-Lösung heraus, bei der jeder Faktor einen der fünf landwirtschaftsbezogenen Themenbereiche repräsentiert (Tabelle 6.1). Jeder Faktor beinhaltet alle vier Items des jeweils a priori postulierten Themenbereichs. Die fünf Faktoren klären gemeinsam 77\% der Varianz auf. Alle empirisch identifizierten bereichsspezifischen Skalen der landwirtschaftlichen Interessen erzielten (sehr) gute Reliabilitäten (Tabelle 6.1).

Tabelle 6.1: Ergebnisse der explorativen Faktorenanalyse zu individuellen Interessen an landwirtschaftlichen Themenbereichen unter Angabe des Reliabilitätskoeffizienten ( $\alpha$ ) für die identifizierten Faktoren (Skala von 1=trifft nicht $z u$ - 4=trifft zu)

\begin{tabular}{|c|c|c|c|c|c|}
\hline $\begin{array}{l}\text { Extrahierte } \\
\text { Faktoren }\end{array}$ & $\begin{array}{l}\text { Eigen- } \\
\text { wert }\end{array}$ & $\begin{array}{c}\text { Varianz- } \\
\text { aufklärung }\end{array}$ & $\begin{array}{l}\text { Cron- } \\
\text { bach's } \alpha\end{array}$ & $\begin{array}{l}\text { Item s: Wenn ich mich mit }[\ldots] \text { beschäftige, bin } \\
\text { ich }[\ldots]\end{array}$ & $\begin{array}{c}\text { Rotierte } \\
\text { Faktorladung }\end{array}$ \\
\hline 1. Landtechnik & 3.27 & $16.37 \%$ & .91 & $\begin{array}{l}{[\ldots] \text { Landtechnik }[\ldots] \text { aufmerksam }} \\
{[\ldots] \text { Landtechnik }[\ldots] \text { angeregt }} \\
{[\ldots] \text { Landtechnik }[\ldots] \text { bedeutsam }} \\
{[\ldots] \text { Landtechnik }[\ldots] \text { interessiert }}\end{array}$ & $\begin{array}{l}0.91 \\
0.89 \\
0.87 \\
0.82\end{array}$ \\
\hline 2. Adkerbau & 3.26 & $16.30 \%$ & .88 & $\begin{array}{l}{[\ldots] \text { Adkerbau }[\ldots] \text { angeregt }} \\
{[\ldots] \text { Adkerbau }[\ldots] \text { interessiert }} \\
{[\ldots] \text { Adkerbau }[\ldots] \text { aufmerksam }} \\
{[\ldots] \text { Ackerbau }[\ldots] \text { bedeutsam }}\end{array}$ & $\begin{array}{l}0.87 \\
0.83 \\
0.74 \\
0.68\end{array}$ \\
\hline $\begin{array}{l}\text { Lebensmittel- } \\
\text { verarbeitung }\end{array}$ & 3.19 & $15.95 \%$ & .90 & $\begin{array}{l}{[\ldots] \text { Lebensmittelverarbeitung }[\ldots] \text { angeregt }} \\
{[\ldots] \text { Lebensmittelverarbeitung }[\ldots] \text { aufm erksam }} \\
{[\ldots] \text { Lebensmittelverarbeitung }[\ldots] \text { interessiert }} \\
{[\ldots] \text { Lebensmittelverarbeitung }[\ldots] \text { bedeutsam }}\end{array}$ & $\begin{array}{l}0.88 \\
0.86 \\
0.85 \\
0.71 \\
\end{array}$ \\
\hline 4. Tierhaltung & 2.98 & $14.92 \%$ & .87 & $\begin{array}{l}{[\ldots] \text { Tierhaltung }[\ldots] \text { angeregt }} \\
{[\ldots] \text { Tierhaltung }[\ldots] \text { interessiert }} \\
{[\ldots] \text { Tierhaltung }[\ldots] \text { aufmerksam }} \\
{[\ldots] \text { Tierhaltung }[\ldots] \text { bedeutsam }}\end{array}$ & $\begin{array}{l}0.89 \\
0.89 \\
0.79 \\
0.69\end{array}$ \\
\hline $\begin{array}{l}\text { Gemüse- und } \\
\text { Obstbau }\end{array}$ & 2.70 & $13.49 \%$ & .89 & $\begin{array}{l}{[\ldots] \text { Gemüse- und Obstbau [...] aufmerksam }} \\
{[\ldots] \text { Gemüse- und Obstbau [...] bedeutsam }} \\
{[\ldots] \text { Gemüse- und Obstbau [...] angeregt }} \\
{[\ldots] \text { Gemüse- und Obstbau [...] interessiert }}\end{array}$ & $\begin{array}{l}0.81 \\
0.73 \\
0.67 \\
0.63\end{array}$ \\
\hline
\end{tabular}




\subsubsection{Messung des situationalen Interesses}

Da wir uns - neben der Untersuchung von landwirtschaftsbezogenen individuellen Interessen - auch für deren Entwicklung interessieren, konstruierten wir zudem ein Messinstrument für das situationale Interesse an der Mitarbeit auf einem Schulbauernhof.

Bestehende Ansätze zur Messung des situationalen Interesses divergieren beträchtlich (vgl. Chen, 1999; Hulleman et al., 2010; Rotgans \& Schmidt, 2011a). Bisher bestanden keine Vorerfahrungen zur Messung des situationalen Interesses im landwirtschaftlichen Kontext allgemein und für unseren Gegenstandsbereich - der Mitarbeit auf dem Schulbauernhof - im Speziellen. Daher entschieden wir uns dafür, auf einem multidimensionalen Interessenkonstrukt aufzubauen (Chen, 1999; 19 Items aufgeteilt in die Subskalen overall situational interest, exploration intention, instant enjoyment, quality of attention, novelty, challenge). Von dieser Skala ausgehend, ermittelten wir mittels einer explorativen Faktorenanalyse, ein für unsere Zwecke (Gegenstandsbereich, Zielgruppe) geeignetes Messinstrument.

Zunächst wurden drei Faktoren mit einer kumulierten Varianzaufklärung von 58\% ermittelt. Mit einer Ausnahme beinhalteten die ersten beiden Faktoren alle Items. Der erste Faktor umfasste die Items der Subskalen overall situational interest, exploration intention, instant enjoyment und quality of attention. Der zweite Faktor enthielt die Items der novelty- und challenge-Subskalen.

Um eine zeitökonomischere Messung zu ermöglichen, identifizierten wir anhand der rotierten Faktorladungen 12 zentrale Items der beiden Faktoren. Die zwei Faktoren wurden in einer zweiten explorativen Faktorenanalyse mit einer leicht verbesserten Varianzaufklärung (61\%) bestätigt (Tabelle 6.2). Somit lassen sich zwei voneinander abgrenzbare Konstrukte beschreiben: die erste Subskala kann als Kern des situationalen Interesses (core situational interest) begriffen werden (vgl. hierzu Rotgans \& Schmidt, 2011a). Die zweite Subskala misst die Wahrnehmung der Mitarbeit auf dem Schulbauernhof als etwas Neues und Herausforderndes (novelty\&challenge). 
Tabelle 6.2: Ergebnisse der explorativen Faktorenanalyse zum situationalen Interesse an der Mitarbeit auf einem Schulbauernhof unter Angabe des Reliabilitätskoeffizienten ( $\alpha$ ) für die identifizierten Faktoren (Skala von 1=trifft nicht $z u$ - 5=trifft $z u$ )

\begin{tabular}{|c|c|c|c|c|c|}
\hline $\begin{array}{l}\text { Extrahierte } \\
\text { Faktoren }\end{array}$ & $\begin{array}{l}\text { Eigen- } \\
\text { wert }\end{array}$ & $\begin{array}{c}\text { Varianz- } \\
\text { aufklärung }\end{array}$ & $\begin{array}{l}\text { Cron- } \\
\text { bach's } \alpha\end{array}$ & $\begin{array}{l}\text { Items: } \\
\text { Mitarbeit auf dem Schulbauernhof ...] }\end{array}$ & $\begin{array}{l}\text { Rotierte } \\
\text { Faktorladung }\end{array}$ \\
\hline $\begin{array}{l}\text { Core } \\
\text { 1. situational } \\
\text { interest }\end{array}$ & 5.29 & $44.10 \%$ & .92 & $\begin{array}{l}{[\ldots] \text { finde ich interessant. }} \\
{[\ldots] \text { macht mir Spaß. }} \\
\text { Bei der Arbeit auf dem Schulbauernhof bin ich } \\
\text { konzentriert. } \\
{[\ldots] \text { begeistert mich. }} \\
{[\ldots] \text { spricht mich an. }} \\
\text { Ich möchte alles, was wir auf dem } \\
\text { Schulbauernhof machen können, erkunden. } \\
{[\ldots] \text { ist spannend. }} \\
\text { Beim Arbeiten auf dem Schulbauernhof bin } \\
\text { ich sehr aufmerksam. }\end{array}$ & $\begin{array}{l}.87 \\
.83 \\
.83 \\
.80 \\
.79 \\
.78 \\
.77 \\
.77 \\
\end{array}$ \\
\hline 2. Novelty \& & 2.06 & $17.14 \%$ & .69 & $\begin{array}{l}\text { Es ist für mich herausfordernd, auf dem } \\
\text { Schulbauernhof zu arbeiten. } \\
{[\ldots] \text { ist für mich neu. }} \\
\text { Bei der Mitarbeit auf dem Schulbauernhof lerne } \\
\text { ich einiges, was mir vorher nicht bekannt war. } \\
{[\ldots] \text { ist kompliziert. }}\end{array}$ & $\begin{array}{l}.76 \\
.71 \\
.70 \\
.65\end{array}$ \\
\hline
\end{tabular}




\subsection{Ergebnisse zu individuellen landwirtschaftsbezogenen Schülerinteressen}

Die individuellen landwirtschaftsbezogenen Schülerinteressen variieren stark zwischen den verschiedenen untersuchten Themenbereichen (für Ergebnisse der T-Tests siehe Abbildung 6.1). Um einen Gesamtwert des Interesses an Landwirtschaft zu erhalten, wurde das Interesse der fünf Themenbereiche gemittelt $(M=2.91, S D=0.52)$. Im Vergleich zu diesem Wert ist das Interesse an Tierhaltung $(M=3.51, S D=0.56)$ und Lebensmittelverarbeitung $(\mathrm{M}=3.19, \mathrm{SD}=.79)$ höher $(p<.001)$, für Gemüse- und Obstbau $(\mathrm{M}=2.63, \mathrm{SD}=.79)$ sowie für Ackerbau $(\mathrm{M}=2.43, \mathrm{SD}=.75)$ niedriger $(p<$ $.001)$.

Das Interesse an Landtechnik $(\mathrm{M}=2.77, \mathrm{SD}=.93)$ liegt zwischen den anderen Themenbereichen. Es ist stärker als das Interesse an Ackerbau und geringer als das Interesse an Tierhaltung und Lebensmittelverarbeitung $(p<.001)$.

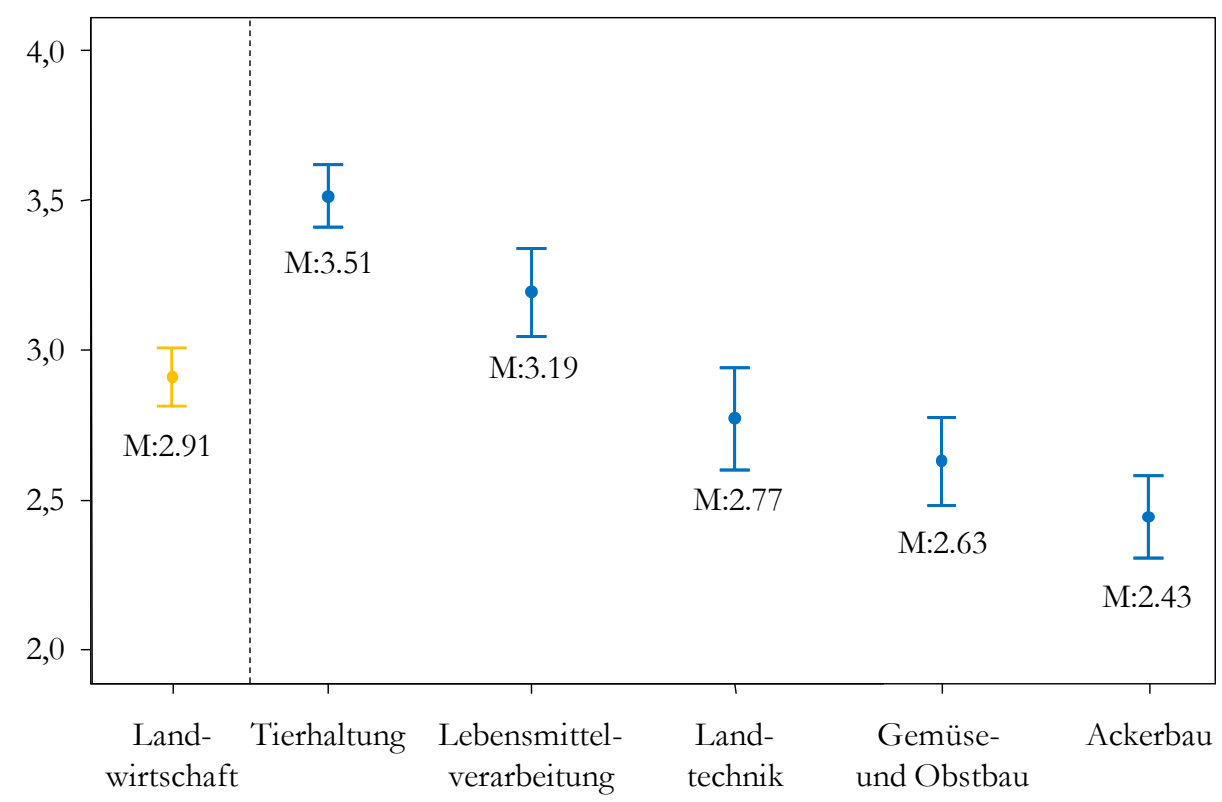

Abbildung 6.1: Landwirtschaftsbezogene Schülerinteressen (Skala von 1=nicht interessiert bis $4=$ interessiert; Fehlerbalken $=95 \%$-Konfidenzintervall des Mittelwerts)

Eine bereichsspezifische Interessenanalyse zeigt deutliche geschlechtsspezifische Unterschiede im Bereich Landtechnik ( $p<.001$, s. Abbildung 6.2). Für Mädchen ist Landtechnik der am wenigsten interessante Bereich $(\mathrm{M}=2.40, \mathrm{SD}=.86)$. Jungen interessieren sich nachweislich stärker als Mädchen für Technik in der Landwirtschaft $(\mathrm{M}=3.14, \mathrm{SD}=.77)$.

Für die vier anderen Bereiche liegen entweder keine geschlechtsspezifischen Interessenunterschiede (Ackerbau, Lebensmittelverarbeitung) vor, bzw. die Mädchen interessieren sich stärker als die Jungen. Letzteres trifft für die Bereiche Tierhaltung ( $p$ 
$<.01)$ sowie Gemüse- und Obstbau $(p<.05)$ zu. In Bezug auf den mittleren Wert für Landwirtschaft sind keine geschlechtsspezifischen Unterschiede nachweisbar.

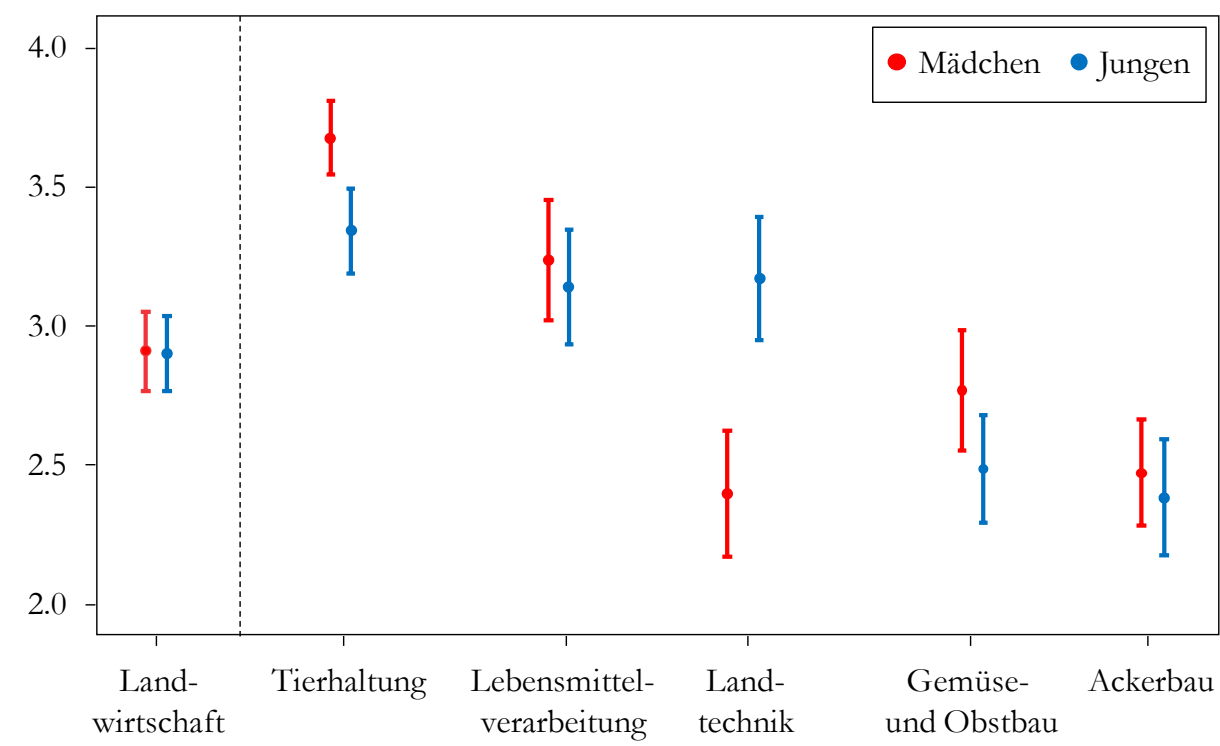

Abbildung 6.2: Geschlechtsspezifische landwirtschaftsbezogene Schülerinteressen (Skala von 1=nicht interessiert bis $4=$ interessiert, Fehlerbalken $=95 \%$ Konfidenzintervall des Mittelwerts)

\subsection{Diskussion und Ausblick}

Unsere Befunde zu bereichsspezifischen Interessen stehen im Einklang mit bestehender Forschung, die-auch unabhängig vom Fokus Landwirtschaft—auf ein vergleichsweise geringeres Interesse an Pflanzen und ein stärkeres Interesse an Tieren verweisen (Dietze, 2007; Finke, 1999; Löwe, 1992). Ebenso werden unsere geschlechtsspezifischen Befunde durch bestehende Forschung gestützt. So konnte gezeigt werden, dass Mädchen über höhere soziale (tierhaltungsbezogene) und instrumentelle (auf Gartenbau bezogene) Naturerfahrungen verfügen als Jungen (Bögeholz, 1999b). Zudem korrelieren häufige Naturerfahrungen stark mit deren Wertschätzung (ebd.). Wertschätzung von Naturerfahrungen steht im Zusammenhang mit wertbezogenen Valenzen von Interesse. Die Bedeutung von Naturerfahrungen für Interesse an der Natur konnte für biodiversitätsbezogene Aspekte durch Leske und Bögeholz (2008) gezeigt werden-wie auch der Zusammenhang zwischen Interesse an der Natur und der Bereitschaft, Biodiversität zu schützen bzw. diese nachhaltig zu nutzen. Letzteres ist sehr vielversprechend für die Umsetzung der Ziele von Bildung für nachhaltige Entwicklung_insbesondere auch auf Schulbauernhöfen.

Um jedoch konkret das Bildungsangebot von Schulbauernhöfen und deren Einbettung in schulischen Unterricht weiterzuentwickeln, führen wir derzeit eine Studie durch, die die Interessenentwicklung über einen Schulbauernhofaufenthalt hinaus begleitet. In einer Interventionsstudie kommen unsere entwickelten Messinstrumente zur Evaluation der Interessen an landwirtschaftsbezogenen Tätigkeiten und Themen 
zum Einsatz. Beleuchtet wird im Rahmen der Interessenentwicklung das Zusammenspiel von situationalen und individuellen Interessen an landwirtschaftlichen Produktionsweisen und -themen. Untersucht wird, inwiefern sich a) ein Schulbauernhofaufenthalt und b) unterrichtliche Nachbereitungsvarianten zum Schulbauernhofaufenthalt, die darauf zielen landwirtschaftliche Interessen zu wecken und aufrechtzuerhalten (Mitchell, 1993), für eine Interessenentwicklung in Bezug auf die angesprochenen Themenbereiche Tierhaltung, Ackerbau, Gemüse- und Obstbau, primäre Lebensmittelverarbeitung und Landtechnik eignen. 


\section{Measuring the Interest of German Students in Agriculture: The Role of Knowledge, Nature Experience, Disgust, and Gender ${ }^{12}$}

\subsection{Abstract}

Modern knowledge-based societies, especially their younger members, have largely lost their bonds to farming. However, learning about agriculture and its interrelations with environmental issues may be facilitated by students' individual interests in agriculture. Up to now, an adequate instrument to investigate agricultural interests has been lacking. Research has hardly considered students' interest in agricultural content areas as well as influencing factors of agricultural interests. In this study, a factorial design of agricultural interests was developed combining five agricultural content areas and four components of individual interest. The instrument was validated with German fifth and sixth graders $(N=1,085)$ using a variance decomposition confirmatory factor analysis model. The results proved a second-order factor of general agricultural interest, with animal husbandry, arable farming, vegetable and fruit cropping, primary food processing, and agricultural engineering as discrete content areas of agricultural interest. Multiple regression analyses demonstrated that prior knowledge, garden experience, and disgust sensitivity are predictors of general agricultural interest, whereas gender additionally influenced the specific interest in four of the five agricultural content areas. Implications are directed at researchers, teachers, and environmental educators concerning how to trigger and develop pupils' agricultural interests.

Keywords: individual interest, agriculture, nature experience, confirmatory factor analysis, predictors, students

\subsection{Agriculture as a Key Factor for Sustainable Development}

From a historical perspective, agriculture has always had the main duty of providing people with food. In particular, until the "technical agricultural revolution" (roughly between the 1930s and 1970s) (Cochrane, 1981), an enormous share of the population made a living from working on the land. Today, in industrialized countries, the role of agriculture has changed in multiple ways. In such contexts, agriculture has lost its outstanding role as a main source of income and employment (Robinson \& Sutherland, 2002). However, agriculture has gained great importance in relation to its current and forecasted environmental impacts in terms of sustainable development goals (Tilman et

12 Source: Bickel, M., Strack, M., \& Bögeholz, S. (2014). Measuring the interest of German students in agriculture: The role of knowledge, nature experience, disgust, and gender. Research in Science Education, online first. 
al., 2001). Although the food that modern agriculture supplies is more than sufficient for the world population, approximately one billion people remain chronically malnourished (United Nations, 2012). Still, merely expanding the total agricultural production would have adverse effects. Agriculture has a great impact on biodiversity loss (e.g., Rockström et al., 2009) and strongly affects the global carbon cycle; it is responsible for approximately $13.5 \%$ of global anthropogenic greenhouse gas emissions, according to the IPCC (Intergovernmental Panel on Climate Change, Pachauri \& Reisinger, 2007).

Contrasting this increasing importance of agriculture, the relationship between the non-agrarian (so called "knowledge-based") society and agriculture is diminishing. In particular, young people have lost their connection with agriculture in daily life (Hubert et al., 2000). This fact can be ascribed to three phenomena of agricultural development during the $20^{\text {th }}$ century in industrial countries: an increasing division of labor, a rapid decline of the working population in agriculture, and vast innovations in agricultural technologies (von Alvensleben, 1998). A study by Brämer (2010) indicated that German adolescents hold idyllic associations and stereotyped pictures of agricultural activities and lifestyles. Misconceptions regarding agriculture are prevalent, and the understanding of basic aspects associated with agriculture and food origins is poor (Dillon et al., 2005).

The exemplified interrelationships between agriculture and sustainable development and the decreasing relationships that young people have with primary food production emphasize that agriculture is a crucial issue within science education and education for sustainable development (ESD). As a consequence, educational efforts in schools and extracurricular activities are becoming increasingly prominent to develop young people's interest and knowledge in agricultural content areas and to achieve the long-term goal of "Gestaltungskompetenz." Gestaltungskompetenz is the central goal of ESD; it describes the ability to "modify and shape the future of society and to guide its social, economic, technological and ecological changes along the lines of sustainable development' (de Haan, 2006, p. 22).

\subsection{Characteristics of Individual Interest and the State of the Art on Interest in Agriculture}

From a theoretical educational perspective, a crucial approach for attracting young people to agriculture involves triggering and developing their individual interests in related content. According to the person-object approach, interest is a relational construct between an individual and an object (Krapp, 2003). An object of interest may be a concrete thing, an action, or a subject area. Thus, in contrast to many related motivational concepts, interest is content specific by definition (Krapp \& Prenzel, 2011). Furthermore, a basic distinction is made between situational and individual interests (Hidi \& Renninger, 2006). Situational interest is a short-term psychological state of 
being interested in current occurrences or activities (Schiefele, 2009), whereas individual interest is regarded as a relatively persistent part of an individual's motivational structure (Krapp, 1999). This paper refers to the acquisition and measurement of individual interest, unless otherwise specified.

Schiefele and Krapp (1996) argued that individual interest comprises different components. The interest components represent positive feelings during an interestbased action and personal value attributed to an object of interest. Such feelings are inherently intrinsic and are directly related to the object of interest, regardless of the object's relation to other objects or topics (Schiefele, 2009). To operationalize the components of interest, Schiefele and Krapp (1996) applied adjectives that express feelings toward and appreciation of an interest object or activities related to the object (e.g., "bored," "stimulated," "important").

A well-developed interest is associated with a willingness to repeatedly concern oneself with the object of interest. So-called person-object engagements can refer to concrete, hands-on actions, abstract cognitive examinations of a particular issue or to activities without conscious control (e.g., daydreaming) (Krapp, 2007). Individual interest has often been found to facilitate learning processes and cognitive achievement (Laukenmann et al., 2003; Randler et al., 2009). Against this background, interest is both a motivational precondition and an objective of learning (Hidi \& Renninger, 2006).

The mentioned characteristics of individual interest highlight its importance in educational settings. In the context of ESD, interest in agriculture can be regarded as part of the motivational basis for the acquisition of "Gestaltungskompetenz."

Research in science education has hardly considered interest in agriculture. The international research project ROSE (Relevance of Science Education) inquired about 10th graders' interests in science. Among a total of 108 items, only three specific aspects of agriculture were included in the survey using single-item measures (benefits and hazards of modern farming, organic farming, and how to improve harvests; e.g., Jenkins \& Pell, 2006). The results from several countries indicated little interest in these aspects compared with other fields of science. Among a German sample $(N=$ 262 ), two of the three items related to agriculture were among the 10 items rated as the least interesting. ROSE participants rated the theme agriculture and plants as the least interesting of the 13 total science subjects that were extracted by exploratory factor analysis (Holstermann \& Bögeholz, 2007). Similar results were found for English students $(N=1,284$, Jenkins \& Pell, 2006), Norwegian students $(N=1,204$, Schreiner, 2006), and Swedish students ( $N=751$, Jidesjö, 2008). The Swedish subproject also applied the same interest items to primary school students $(N=112)$. Again, the aspects related to agriculture were among the 10 least interesting items (Jidesjö, 2008). 
More recently, a representative survey among the German population above the age of 14 years indicated that younger people are less interested in agriculture than older people are (the age groups were not further specified) (TNS Emnid, 2012).

Summing up, previous studies on agricultural interests were either based on specific aspects of agriculture that did not represent basic agricultural content areas or did only investigate the overall interest in agriculture without any differentiation. Schiefele (2009) recommended investigating complex interest objects in a differentiated manner. To date, a targeted approach distinguishing between typical agricultural branches (such as arable farming, animal husbandry, or vegetable and fruit cropping) is lacking. The development of a valid and reliable agricultural interest measure taking into account different agricultural content areas is a necessary prerequisite for research in this field.

\subsection{Common Predictors of Individual Interest in Agriculture-related Objects}

Research has exposed different factors that relate to interest. Influencing factors depend on the object of interest and on the underlying conceptualization of interest (e.g., situational versus individual interest; cf. Hidi \& Renninger, 2006). Correspondingly, a general distinction can be made between factors that influence individual and situational interest. The factors that influence individual interest relate to personal characteristics, emotions, competences, and knowledge but may also be prior experience. Influencing factors concerning situational interest are bound to specific situations, and their conditions in instructional settings may be under the control of teachers (e.g., elements and methods of instruction) (Bergin, 1999). Because our study focuses on individual interests, the corresponding findings will be outlined.

Information regarding the factors that influence agricultural interests is still lacking. However, previous research concerning related interest objects offers valuable clues to possible influencing factors for agricultural interests. In order to extract such factors for the present study, we analyzed studies that considered interest objects such as animals, plants, or nature in general. Corresponding findings will we outlined in the following paragraphs.

Gender and interest: Gender strongly influences students' interest in certain domains. Many studies have shown that girls are more interested in biology than boys (Jones et al., 2000; Prokop, Tuncer, \& Chudá, 2007). As gender stereotypes suggest, boys show higher rates of interest in physics and technological subjects (Holstermann \& Bögeholz, 2007; Schreiner, 2006). Studies have consistently found that compared with boys, girls are more interested in animals (e.g., Bögeholz, 2002; Finke, 1999; Jones et al., 2000). More ambiguous is the role of gender with respect to interest in plants. Finke (1999) suggested that girls are more interested in plants than boys are. 
By contrast, Holstermann and Bögeholz (2007) showed the opposite results. Against this background, an influence of gender on certain agricultural content areas (in particular, content areas related to farm animals and agricultural engineering) can be expected.

Emotions and interest: Emotions play a crucial role in interest and its development (Bergin, 1999). Disgust is one of the basic emotions (Izard, 1977) marking an emotional state of negative valence and activation. Because disgust appears to be a short-term state of perceived repulsion, a disgusted person will attempt to avoid the provoking stimulus as a defense mechanism. However, disgust also varies across individuals as a personal trait. This so-called disgust sensitivity is a lasting predisposition in response to certain stimuli (Izard, 1977). Feelings of disgust may be triggered by food, body excretions, or contact with dead bodies (Haidt, McCauley, \& Rozin, 1994). Such feelings can also be provoked by certain nature experiences with disliked animals, the handling of organic materials, and the "dirtiness" of nature in general (Bixler \& Floyd, 1997). Thus, disgust may be particularly relevant to agriculture (e.g., animal feces, dirt, barn smells, and slugs in the garden).

Holstermann et al. (2012) found negative relationships between disgust sensitivity (assessed approximately one week prior to the class as a personal trait) and interest during a biology dissection class. Disgust sensitivity negatively predicted students' interest during the dissection. Although relationships between disgust sensitivity and interest in agriculture have not yet been studied, a negative relationship can be assumed (Dillon et al., 2005). For this reason, we expected that disgust sensitivity as regards typical agricultural and farm stimuli negatively affects students' agricultural interests.

Nature experience and interest: Several studies have analyzed the influence of nature experience on interest and related constructs. Chawla and Cushing (2007) conducted a meta-analysis examining the promotion of active care of the environment among children and adolescents. Across several cultural backgrounds, they found that the majority of members in environmental clubs identified nature experiences during childhood as significant for their current membership in the clubs. Accordingly, the authors concluded that "nature activities in childhood and youth [...] are key 'entry-level variables' that predispose people to take an interest in nature" (Chawla \& Cushing, 2007, p. 440). Leske and Bögeholz (2008) found positive correlations between different types of nature experiences (scientific $r=.54$, ecological $r=.41$, and aesthetic experience $r=.47$ ) and interest in nature among students in grades 7 to 10 . Using path analysis, Cheng and Monroe (2012) found that previous experiences in nature directly influence interest in nature-based activities. Kals, Schumacher, and Montada (1999) achieved similar results. Present nature experiences and past nature experiences 
during childhood were found to be the strongest predictors of developing an affinity toward and interest in nature among adults.

Bögeholz (1999a) identified strong correlations $(r=.70-.86)$ between the frequency of nature experiences and appreciation of the aesthetic, scientific, instrumental, ecological, and social dimensions of nature. Appreciation is closely linked to personal value (Bögeholz, Bittner, \& Knolle, 2006), which is one component of the individual interest conception described above. Caring for pets, which represents a social dimension of nature experience (Bögeholz, 2006), was found to be correlated with positive attitudes toward animals (Prokop \& Tunnicliffe, 2010). This relation may also be affective as to farm animals; accordingly we assume that daily experience with pets increase interest in farm animals. Furthermore we assume that experiences on farms and in the garden at home potentially increase agricultural interests.

Prior knowledge and interest: The interrelationship between interest and (prior) knowledge has been analyzed in many different ways and in a variety of contexts. However, results referring to interest in agriculture or related interest objects, such as animals or plants, are lacking. Most findings derive from research on interest in reading (e.g., Alexander et al., 1995; Schiefele \& Krapp, 1996) or physics (Laukenmann et al., 2003) or situational interest in a lesson on ecology (Randler et al., 2009).

A meta-analysis of the relationships among interest, prior knowledge, and learning suggested that there is "a substantial linear relationship between interest and prior knowledge" (Tobias, 1994, p. 50). Several studies have confirmed weak (approx. $r=$ .15-.25; Laukenmann et al., 2003; Randler et al., 2009; Schraw, Bruning, \& Svoboda, 1995) or moderate correlations between prior knowledge and interest $(r=.38$; Alexander et al., 1995).

Such a correlation between these two variables is consistent, but there are differences among opinions and research approaches concerning the direction of influence. Educational research has typically investigated the role of interest in related learning outcomes (for an overview, see Hidi \& Renninger, 2006). Other researchers have analyzed the influence of prior knowledge on interest (e.g., Schraw et al., 1995). Some studies apply both variables as predictors of learning outcomes or achievement (Alexander et al., 1995; Randler et al., 2009).

Hidi and Renninger (2006) assumed that during the process of interest development, knowledge increases successively, especially for well-established interest. Because of the importance of prior knowledge on interest in many different domains, we assume that prior agricultural knowledge strengthens agricultural interests.

Summing up the mentioned findings, we extracted gender, disgust sensitivity (related to agricultural stimuli), nature experiences concerning pets, on farms, and in 
the home garden, as well as prior agricultural knowledge as potential factors that determine agricultural interests. Gender is an important personal predisposition. Disgust sensitivity is an emotional trait, whereas prior knowledge clearly represents a cognitive variable. In addition, various individual nature experiences are considered. Together, this set of factors represents a coherent picture that comprises the aforementioned general aspects that affect individual interest (Bergin, 1999).

\subsection{Aims and Research Questions}

Given the scarce scientific evidence concerning agricultural interests, we had two research objectives. The first aim was to modify an interest scale that had been developed and applied in other interest domains (cf. Schiefele \& Krapp, 1996) in order to gain a valid and reliable assessment of agricultural interests. The instrument was intended to distinguish between interests in different agricultural content areas and to be applicable to students in grades 5 and 6 .

The agricultural content areas considered were derived from theoretical assumptions. According to Rubenstein (2010), animal husbandry (the first content area) and plant production are the two main branches of agricultural production. The former pertains to all types of activities related to domesticated farm animals. Concerning plant production, arable farming (the second content area) differs in many aspects from vegetable and fruit cropping (the third content area), including crop types, area coverage, and operational procedures. Historically, rural home economics have been closely linked to agriculture (Vonderach, 2004). Today, this link is still valid for peasant farms in industrialized countries and in less developed countries (MeinzenDick, Behrman, Menon, \& Quisumbing, 2012). Thus, we added primary food processing as the fourth content area. This content area encompasses typical processing steps for raw materials, such as processing milk, baking bread, or preserving food.

Today, farming in industrialized countries can hardly occur without machinery; therefore, agricultural engineering was added as a discrete content area representing the use of technical devices on farms (the fifth content area). In summary, we investigated the following content areas of agricultural interest: animal husbandry, arable farming, vegetable and fruit cropping, primary food processing, and agricultural engineering.

With a sound instrument to investigate agricultural interests, the second objective was to identify factors that influence agricultural interests. Since prior research did not address this specific issue, we identified possible factors on the basis of results concerning similar interest objects. The literature encouraged consideration of gender, disgust sensitivity, previous agriculture-related nature experiences, and prior knowledge as predictors of agricultural interests. By testing these variables that 
represent personal, cognitive, emotional, and experience-based aspects, our aim was to provide information for further research and educational practice that may help to develop student's agricultural interests more consciously.

According to these objectives, the following research questions were posed:

i) Can students' interests in different agricultural content areas be empirically distinguished?

ii) To what extent can gender, disgust sensitivity, previous agriculture-related nature experiences, and prior knowledge predict different content areas of agricultural interest?

\subsection{Method}

\subsubsection{Participants and Procedure}

To recruit teachers who would be willing to participate in the research project on agricultural interests, we asked five German educational farms for assistance. On our behalf, the farms asked their prospective customers (namely, school classes) for participation. Prior to the survey, we sent information letters describing the study purpose via the farms to all teachers of grades 5 and 6 school classes that planned to visit one of the cooperating farms during 2012. To avoid distortion caused by a subsequent visit to an educational farm, the questionnaires were completed in school approximately two weeks prior to the farm visit. Additionally, we directly contacted some schools and asked them to participate in the study.

The sample comprised 1,085 students, including 598 fifth graders and 487 sixth graders $\left(\mathrm{M}_{\mathrm{age}}=10.99, \mathrm{SD}=.77,51.7 \%\right.$ male $)$ from secondary modern schools $(n=$ $478)$, gymnasiums ( $n=410)$, Waldorf schools $(n=124)$, and comprehensive schools $(n$ = 73) dispersed over six German federal states $^{13}$. Questionnaires were sent to teachers, who distributed them to their students in class. The students completed the questionnaires individually and returned them to their teachers. The teachers sent the questionnaires back to the researchers.

\subsubsection{Measures}

Dependent variables: To assess agricultural interests, a 4 (interest components) * 5 (agricultural content areas) factorial design with 20 items was created (see Figure 7.1). We modified the approach of Schiefele and Krapp (1996) by presenting the interest

\footnotetext{
${ }^{13}$ After four years of primary school, the German school system provides three main secondary school tracks. Gymnasium is the most academic track and the only one that allows direct entry into a university. Realschule finishes after year 10, and Hauptschule finishes after year 9. Today, some federal states combine Hauptschule and Realschule in secondary modern schools. Comprehensive schools comprise students of all academic levels. Waldorf schools are private schools that follow the anthroposophic education model.
} 
components in bipolar adjective pairs with a four-point rating scale. The four components assessed were interested (boring), stimulated (impassive), attentive (inattentive), and meaningful (unimportant) ${ }^{14}$.

The questionnaire highlighted typical activities as examples for each content area (e.g., animal husbandry: "milking cows, feeding pigs, collecting eggs"). The five content areas were systematically combined with the four interest components (see Appendix I). A pretest of the instrument with 115 students yielded satisfactory results (Bickel \& Bögeholz, 2013b).

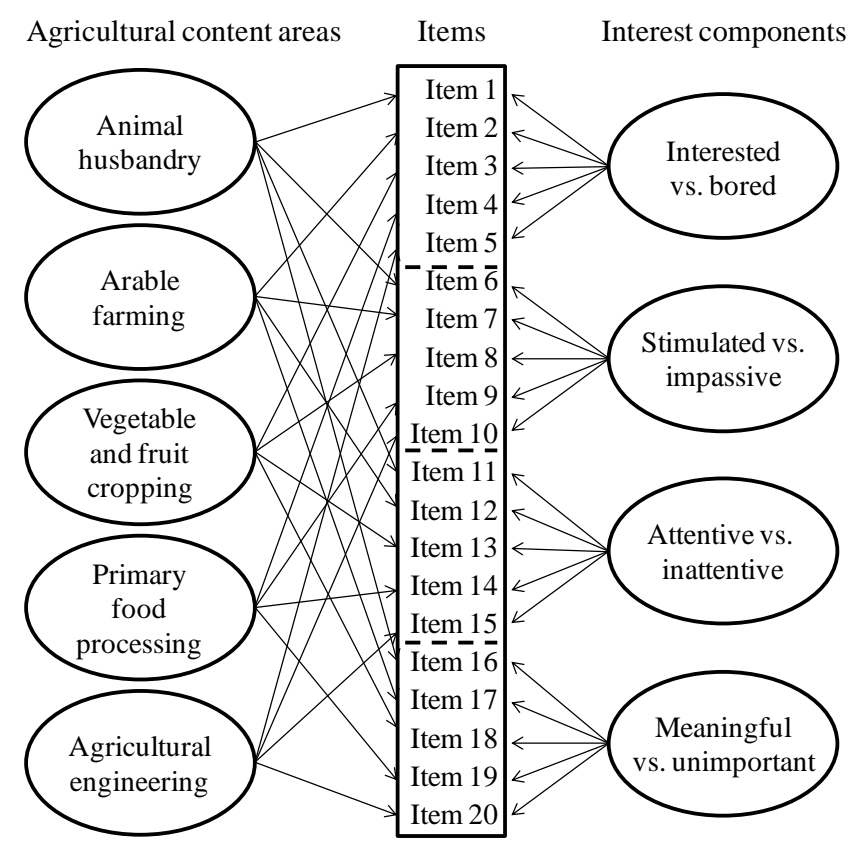

Figure 7.1: Factorial design of the measure of agricultural interests

Predictor variables: The predictor set encompassed six variables. Gender was included as a sociodemographic variable. Frequency of farm visits was assessed with a single item ("How much time in days, weeks, or months do you spend on a farm in an average year?"). Garden experience combined the following binary-coded information: the students were asked about the presence of a home garden (offering everyday aesthetic and scientific nature experience; cf. Bögeholz, 1999b) and whether they occasionally helped with working in a garden (either at home or elsewhere). To ensure that the children considered common tasks conducted during gardening, the questionnaire contained examples ("sowing, weeding, harvesting fruits and vegetables"). Participants who did not have access to a home garden and who did not work in a garden were given the score low (0). Those who either had a home garden at

\footnotetext{
${ }^{14}$ Further details on the instrument development can be found in Bickel and Bögeholz (2013b).
} 
their disposal or claimed to have gardening experience were given the score moderate (1). Students scored high (2) if both items were affirmed.

To measure prior knowledge, we adapted the short scale by Schraw et al. (1995) comprising three items on a five-point rating scale (see Appendix I). To assess agriculture-related disgust sensitivity, three items on a general disgust sensitivity scale (Schienle, Walter, Stark, \& Vaitl, 2002) relating to animals were selected (e.g., "You step on an earthworm while barefoot") and four new items that considered situations related to agriculture were added (e.g., "You collect slugs from the vegetable bed"). The answers ranged from not disgusting (1) to very disgusting (4) (see Appendix I). Keeping a pet was integrated as an additional predictor of interest in animal husbandry and was assessed by a single dichotomous item.

\subsubsection{Data Analysis}

To validate the factorial design of the measure of agricultural interests, a confirmatory factor analysis (CFA) was applied. As latent variables, the measurement model included a second-order general factor (i.e., general agricultural interest) and first-order factors representing the five agricultural content areas and the four interest components. All 10 latent variables were restricted to orthogonality, and their path to the items maintained tau-equivalence (e.g., Graham, 2006). The variance of the five interest content areas was set equal and the variance of the four interest components was set equal, too. This fixed-links model (Schweizer, 2010) estimates only three variance sources: the general factor $(\xi)$, the specificity of the agricultural content areas $\left(\zeta_{1}\right)$, and the specificity of the interest components $\left(\zeta_{2}\right)$. Based on the correlation matrix of the interest items, the model was estimated with LISREL 8.80 (Jöreskog \& Sörbom, 1996). The adjusted goodness-of-fit index (AGFI; target value: $>0.8$; Sharma, 1996), the parsimony goodness-of-fit index (PGFI), and the root mean square error of approximation (RMSEA; target value: < 0.08; Browne \& Cudeck, 1993) were documented.

Stepwise multiple regression analyses (forward selection) were applied to prove the predictors of agricultural interests using the Statistical Package for the Social Sciences (SPSS 19.0). Two-way interactions of the predictor pairs were tested according to Aiken and West (1993). According to Cohen's effect size convention, significant predictors $(p<.05$, two-tailed) were accepted only if the absolute value of the standardized regression coefficient beta achieved .10 (small effect).

\subsection{Results}

\subsubsection{Variance Parts in the Factorial Model of Agricultural Interests}

To answer the first research question, the structural equation model was created to identify whether the proposed factorial design of Figure 7.1 could be confirmed and 
whether there is a latent second-order factor behind all 20 items representing general agricultural interest.

The CFA findings validated the factorial design of the agricultural interest model, with nearly $80 \%$ of the item variance explained (see Figure 7.2 ). The strongest sources were the five agricultural content areas, which explained $50 \%$ of the item variance. At $5.5 \%$, the interest components contributed a significant but smaller share of the item variance. General agricultural interest (the second-order factor) accounted for $24 \%$ of the item variance. Given that only three parameters were estimated, the restricted CFA model achieved reasonable global fit indices $(d f=187, \mathrm{AGFI}=.880, \mathrm{PGFI}=.795$, and RMSEA $=.075)$.

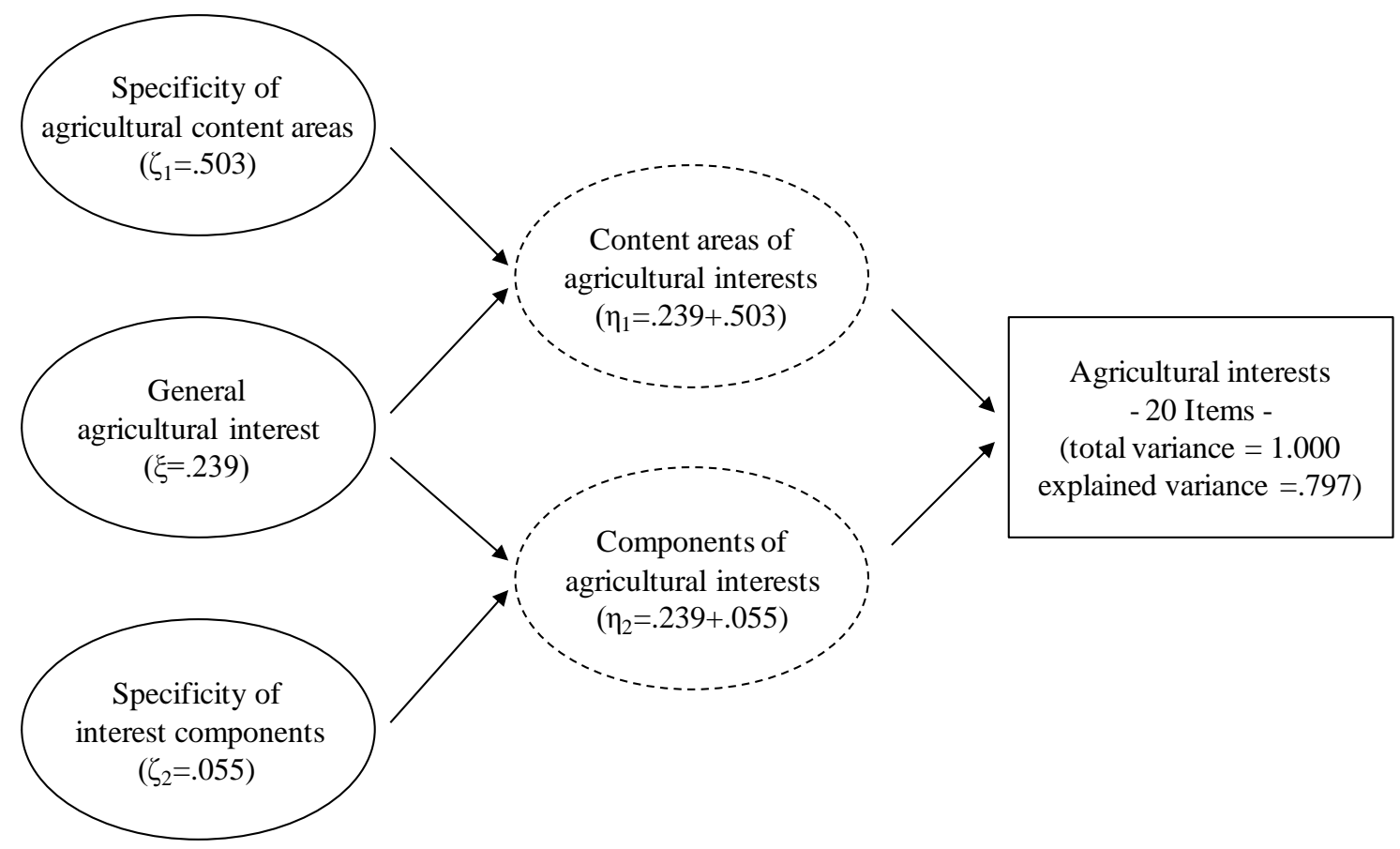

Figure 7.2: Variance parts in the structure of agricultural interests

The results showed the discriminatory value of the five agricultural content areas. The considerable proportion of item variance ascribed to the general agricultural interest suggested the value of scrutinizing it in further analyses. Because of the comparatively small amount of variance caused by the interest components, we refrained from integrating the interest components as separate variables in further analyses.

\subsubsection{Predictors of Agricultural Interests}

According to the results obtained by the CFA, we first estimated a regression model for general agricultural interest. The score for general agricultural interest was computed as the mean score of all 20 interest items (Cronbach's $\alpha=.908)$. To analyze the additional interest specificity in the agricultural content areas, all of the interest items 
were ipsatized by subtracting the score for general agricultural interest. Thereafter, the scores for the interest specificities of the content areas were computed by averaging the respective four ipsatized items (animal husbandry specificity, $\alpha=.876$; arable farming specificity, $\alpha=.773$; vegetable and fruit cropping specificity, $\alpha=.774$; primary food processing specificity, $\alpha=.835$; and agricultural engineering specificity, $\alpha=.922$ ). Applying the ipsatized scores, content area-specific prediction patterns can be revealed beyond the predictive findings for general interest in agriculture.

The predictor set included gender, prior knowledge, garden experience, disgust sensitivity, frequency of farm visits, and keeping a pet (as an additional predictor of interest in animal husbandry). Grade in school was initially tested but-as expecteddid not qualify in any regression model because we investigated only students in grades five and six. None of the regression models showed evidence of two-way interaction effects for any two predictors.

As documented in the upper section of Table $7.1,22.2 \%$ of the variance in general agricultural interest could be explained. Prior knowledge was the most powerful predictor, with a medium effect size according to Cohen's convention. Garden experience also enhanced general agricultural interest, and disgust sensitivity lowered it. 
Table 7.1: Stepwise regression of agricultural interests to gender, prior knowledge, garden experience, disgust sensitivity, frequency of farm visits, and keeping a pet (forward inclusion)

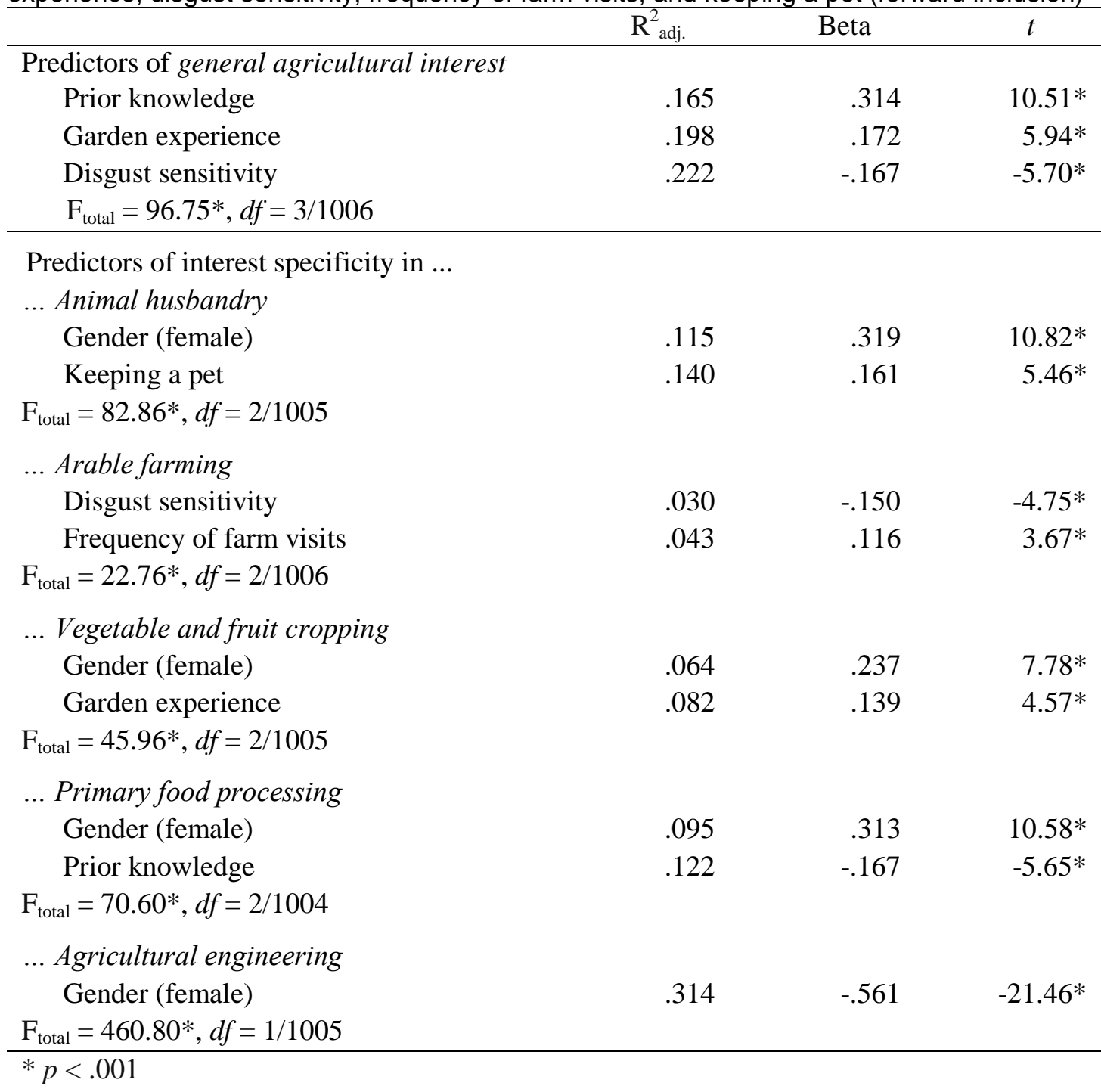

These three influences on general agricultural interest are relevant across all five agricultural content areas. The predictors of the interest specificities regarding the agricultural content areas, as documented in the lower parts of Table 7.1, have to be interpreted as additives to the list of predictors of general agricultural interest outlined above.

The interest specificity of animal husbandry was predominantly determined by gender. Girls were found to be more interested in animal husbandry than boys were. Moreover, keeping a pet positively influenced the animal husbandry interest specificity. Together, both predictors explained $14 \%$ of the variance of the interest specificity of animal husbandry.

The arable farming interest specificity was the only interest specificity of all content areas not predicted by gender. The tested predictors explained only $4.3 \%$ of specific 
interest in arable farming. This result underlined the applicability of the predictors of general agricultural interest (knowledge, garden experience, and disgust) to the interest specificity in arable farming. The negative influence of disgust sensitivity was particularly strong, reducing general agricultural interest and further lowering the arable farming interest specificity. Frequency of farm visits qualified as a second predictor for this specific content area. However, this predictor contributed to only $1.3 \%$ of the additional explained variance.

Concerning the interest specificity of vegetable and fruit cropping, gender and garden experience explained $8.2 \%$ of the variance. The influence of garden experience was noteworthy for the interest specificity in this content area compared with all others, as it heightened the general agricultural interest and the vegetable and fruit cropping interest specificity.

With respect to the interest specificity of primary food processing, $12.2 \%$ of the variance could be attributed to gender and prior knowledge. Likewise, for animal husbandry and vegetable and fruit cropping, girls had a stronger specific interest in primary food processing than boys did. Prior knowledge had already been confirmed to enhance general agricultural interest (upper part of Table 7.1). In contrast, prior knowledge negatively influenced the primary food processing interest specificity. Consequently, prior knowledge was a weaker influencing factor for interest in primary food processing than for all other content areas.

The interest specificity of agricultural engineering was best explained by the predictors included in the analyses. Gender explained more than $30 \%$ of the variance. Contrary to the interest specificities of all the other content areas that were affected by gender, the interest specificity of agricultural engineering was stronger for males than for females.

\subsection{Discussion}

This study advocates for reconnecting young people in modern knowledge-based societies to agriculture. This argument is connected with the superordinate need to provide learning opportunities in agriculture-related issues to foster education for sustainable development. As a first step in this direction, we investigated students' interests in agriculture to identify construct elements and predictors of agricultural interests. To measure agricultural interest in different content areas, a factorial design was developed, tested, and validated using a CFA procedure. The results confirmed the five theorized agricultural interest content areas: animal husbandry, arable farming, vegetable and fruit cropping, primary food processing, and agricultural engineering. The content areas explained half of the item variance. Furthermore, the results proved a second-order factor, indicating that the instrument can also be applied to assess general agricultural interest. 
The predictive findings highlighted the importance of prior knowledge, garden experience, agriculture-related disgust sensitivity, and gender in explaining agricultural interests. The following part of the discussion provides insight into the construct validity of the measure of agricultural interests, and the second part examines the found prediction patterns.

\subsubsection{Construct Validation by Variance Partitioning}

To validate the theorized measure of agricultural interests, we applied CFA. In this journal, Kier, Blanchard, Osborne, and Albert (2013) recently introduced CFA to compare the theoretical underlying structure of a measure with its empirical structure. In particular, the second-order factor structure (in the present study, the general agricultural interest) and the factorial design (so-called bifactorial models; see Figure 7.1) (Schweizer, Altmeyer, Reiß, \& Schreiner, 2010) require confirmatory modeling. The proposed structure of agricultural interests created a model that exceeded a conventional congeneric CFA in two respects.

First, a congeneric CFA restricts only the loadings of items from latent variables that are expected not to contribute to the item (i.e., to zero) and allows the expected loadings to vary freely. Instead, we applied a model that maintained the tauequivalence assumption by restricting all expected loadings on a latent variable to be equal. The advantage of tau-equivalence models is the direct estimation of the variance of each latent variable (Schweitzer, 2010). Second, the factor levels were set to be equal for each of the two first-order factors (i.e., the specificity of the agricultural content areas and the specificity of the interest components), thereby strongly reducing the number of estimated coefficients and obtaining a highly parsimonious model. The tau-equivalent CFA variance decomposition model estimated only the three local estimators that were used to evaluate the strength of the structural factors (i.e., directly matching the true variance achieved by averaging items with equal weights) (Graham, 2006): a quarter of the item variance was caused by the second-order factor (i.e., general agricultural interest), and half of the variance was caused by the specificity of agricultural content areas, whereas only $5 \%$ was caused by the specificity of the interest components. As a result, the specificity of agricultural content areas was proven to be the most important variance part and was therefore examined in the regression analyses as well as the second-order general factor. By contrast, the interest components adapted from Schiefele and Krapp (1996) were-although statistically significant-a practically negligible source. Consequently, without much loss of information, the factorial design could be simplified to a facet model of general agricultural interest in terms of the second-order factor and the first-order content elements only. If future research prefers to follow this simplified structure, then the raw scores of the correlated dimensions may be computed and analyzed rather than using ipsatized content area-specific scales. 


\subsubsection{Integration of Predictive Findings}

The predictor set to explain agricultural interests included five variables. In summary, prior knowledge, garden experience, disgust sensitivity, and gender were the most important for general agricultural interest and the interest specificities in the five agricultural content areas.

Most prediction patterns were in agreement with related research. The outstanding role of (prior) knowledge in interest (e.g., Alexander et al., 1995) also applied to general agricultural interest. Only primary food processing was less influenced by prior knowledge. German students' prior knowledge is more closely related to "typical" agricultural content areas, such as animal husbandry and the cultivation of crops (Rubenstein, 2010), than to less commonly known agricultural areas, such as primary food processing. This result may have been observed because of the German national standards in science education (KMK, 2005) and the school subjects being taught to fifth and sixth graders that put an emphasis on animal and plant-related knowledge transfer (Bickel \& Bögeholz, 2013a).

Garden experience was found to be the second strongest predictor of general agricultural interest and adds to previous results highlighting the positive effect of nature experience on interest in related domains (Cheng \& Monroe, 2012; Kals et al., 1999; Leske \& Bögeholz, 2008). Garden experience had the strongest predictive power for the interest specificity of vegetable and fruit cropping, possibly because German students conduct most of their garden work with respect to vegetables, fruits, and flowers.

The third predictor of general agricultural interest was disgust sensitivity. Consistent with the findings of Holstermann et al. (2012), our results suggested that interest in all agricultural content areas is negatively affected by disgust. This finding particularly applied to arable farming - the only interest content area for which disgust had an additional content area-specific negative effect. Apparently, young people associate arable farming with triggers of disgust, such as mud and dirt (Bixler \& Floyd, 1997). However, similar associations could also have been projected on other agricultural content areas. Animal husbandry could have been linked with stimuli such as animal feces or bad smells in barns (Haidt et al., 1994). By contrast, students may relate more positive emotions with farm animals because of their idyllic images of animals (Bowd, 1982).

Even if it did not predict general agricultural interest, gender was found to be the strongest predictor of interest specificities in four out of five content areas. Among these content areas, agricultural engineering was the only content area that boys were more interested in than girls were. This result mirrors the gender stereotype that boys are more interested in technological issues than girls are; a finding that is consistent with former and recent studies concerning students of different school ages, countries, 
and cultures (Baram-Tsabari \& Yarden, 2009; Cakmakci et al., 2012; Holstermann \& Bögeholz, 2007; Jones et al., 2000; Schreiner, 2006). There is broad consensus in gender-oriented research that girls are more interested in biology than boys are (Cakmakci et al., 2012; Jones et al., 2000; Prokop et al., 2007). This finding was confirmed for the interest specificities in three out of four agricultural content areas related to biology. More precisely, the girls in the study exhibited greater interest in animal husbandry, vegetable and fruit cropping, and primary food processing. Thus, findings that girls are more interested in animals than boys are (Finke, 1999; Jones et al., 2000) also appear to apply for farm animals. Previous results regarding the role of gender in interest in plants are conflicting. This study found that girls were more interested in vegetable and fruit cropping than boys were, thus supporting the findings of Finke (1999) but opposing evidence documented by Holstermann and Bögeholz (2007). Girls' greater interest in primary food processing conforms to females' stronger interest in nutritional issues (e.g., Grunert, Fernández-Celemín, Wills, Bonsmann, \& Nureeva, 2010).

Frequency of farm visits was a less important predictor of agricultural interests; it was only related to the arable farming interest specificity. It can be assumed that farm visits indirectly influenced general agricultural interest because frequency of farm visits was moderately correlated with prior knowledge $(r=.32, p<.001)$. In industrialized countries, most farms are specialized and mechanized, reducing the need for manual labor (Robinson \& Sutherland, 2002). This tendency is particularly applicable to activities in arable farming, such as seeding, fertilizing, and harvesting, which are almost exclusively performed by machines. As a consequence, it can be assumed that children's experiences during farm visits are characterized by observation rather than by active engagement in arable farming activities. Therefore, frequency of farm visits likely represents rather passive observations. In contrast, garden experience, which had direct and more predictive power, implied a degree of active involvement of children in garden work.

To gain deeper insights into the role of farm visits in agricultural interests, further studies should focus on both the frequency and qualitative aspects of farm visits. Future studies could integrate the level of active involvement and consider who initiates farm visits. There is evidence that "hands-on," active engagement of learners elicits interest (Mitchell, 1993; Swarat et al., 2012). According to self-determination theory, deliberate self-chosen decisions strengthen individual autonomy (Deci \& Ryan, 2000), which is regarded as a distinctive factor of human well-being that supports interest development.

\subsection{Limitations}

Before we draw conclusions, we will address four methodological issues that could compromise the validity of our results: i) the composition of the agricultural interest 
scale in terms of content areas, ii) the sampling method, iii) the self-reported status of data, and iv) possible doubts regarding the causal direction of the relationship between three predictor variables and agricultural interests.

i) Five agricultural content areas were derived from theoretical considerations, but completeness is not guaranteed. The content areas were chosen in consideration of the target population of our study because the notion of what agriculture implies needed to be consistent with the participants' range of experiences. Concerning other populations in terms of age (e.g., students of higher education), more complex content areas could have been added, such as agricultural interrelationships with the preservation and sustainable utilization of biological diversity.

ii) Most of the participants were recruited via educational farms that the children were going to visit several weeks after the survey. A smaller part of the sample was obtained through direct contact with schools that did not plan a subsequent farm visit. Concerning the former, the participants' interest levels could have been enhanced by anticipation of the farm visit (Bogner, 1998). However, confounding by the predictor variables would have been more challenging for our results. Concerning the predictor variables, the groups of participants differed only with respect to their gender distribution: among the participants who were recruited through direct contact with schools, $56 \%$ of the participants were male, compared with $49 \%$ in the other group $(\chi(1)=11.17, p<.01)$. General agricultural interest differed between the two groups; however, there was no group difference regarding interest specificities in the agricultural contents areas predicted by gender (animal husbandry, vegetable and fruit cropping, primary food processing, and agricultural engineering). Thus, the sampling bias did not affect the results.

iii) All of the data were self-reported and could thus be subject to socially desirable answering behavior. To reduce the effects of social desirability, several provisions were made in advance. The questionnaires ensured full anonymity, and the children were asked to state their own opinions and to answer all questions honestly. There was no contact between the researchers and the participants that could have caused any type of emotional response caused by sympathy or antipathy that may have in turn influenced the participants' answers. A bias related to the students' sympathy or antipathy for the teacher cannot be fully eliminated but does not appear likely, as the students were informed that the survey was initiated by a non-school institution. Additionally, social desirability typically results in a very large amount of variance in the second-order general factor, which, in this respect, remained comparably weak in the agricultural interests' model.

iv) In general, regression models are based on the assumption that predictor variables have an effect on the dependent variable. Strictly speaking, however, identified correlations cannot be interpreted as causations. In the study presented, 
plausible concerns could arise with a reverse of the postulated causal relationship between garden experience, frequency of farm visits, and prior knowledge on the one hand and agricultural interests on the other hand.

Garden experience and frequency of farm visits represented agriculture-related nature experiences. Several studies suggested that nature experience is an important predictor of interest (e.g., Chawla \& Cushing, 2007; Cheng \& Monroe, 2012; Liefländer, Fröhlich, Bogner, \& Schultz, 2013). However, interest can be considered a trigger of nature experience. Because the garden experience variable accounted for whether the participants had access to a garden, it is plausible to assume that it was a source rather than a consequence of interest.

Concerning frequency of farm visits, we had no information about who initiated the students' farm visits. Because most children in Germany currently have little contact with agriculture in daily life, farm stays are likely to have occurred in the context of visits to relatives and friends or during shopping opportunities and social events on farms. Accordingly, a reverse of the causal relationship is not likely.

The same notion as that applied to the nature experience-based variables may hold true for the relationship between prior knowledge and interest. Knowledge may encourage interest in a particular object, but an existing interest may also be a source of (further) knowledge acquisition, as shown by research on interest development (e.g., Hidi \& Renninger, 2006). Studies have suggested that young people in Germany gain their agricultural knowledge to a large degree in school (TNS Emnid, 2012)-a source of information that they cannot choose freely and that therefore is not inspired by students' interest.

\subsection{Conclusions}

The instrument that was developed to measure agricultural interests may be a starting point for further interest studies in school and environmental education, particularly for assessing programs that are implemented on farms. The instrument can be used to investigate the status quo of agricultural interests and to evaluate interventions in a repeated measure design, as the instrument is fairly short and has demonstrated good reliability.

Prior knowledge, garden experience, disgust sensitivity, gender, and, to a lesser degree, frequency of farm visits, were found to predict agricultural interests. Thus, models explaining agricultural interests should consider the influencing factors, as shown in this study. Furthermore, additional predictors could be integrated into further investigations to gain additional explanatory power.

Because frequency of farm visits had little predictive power, further studies should also consider the qualitative aspects of farm visits. Participants could be asked about the degree of active involvement and the types of activities in which they have engaged 
on farms. In addition, the potential for farm education programs to develop agricultural interests could be investigated (e.g., within the scope of pre-post-control design studies).

The results of this study suggested that nature experiences i) are more powerful if they actively involve students (e.g., garden experience was a stronger predictor than frequency of farm visits) and ii) have a greater influence when they are more closely related to the object of interest (interest in vegetable and fruit cropping was best predicted by garden experience). Farm education programs should foster students' active participation to enable first-hand agriculture-related experiences. Furthermore, educators should consider gender differences regarding agricultural interests. Educators could apply a type-oriented approach (Bögeholz, 1999a) and offer free choice between different agricultural activities to strengthen existing interests. Alternatively, they could provide a given range of activities for all participants to address a variety of agricultural content areas and to overcome stereotypical gender differentiation by triggering new interests (Mitchell, 1993).

Individual barriers to farm experiences caused by feelings of disgust should be taken seriously. However, farm experience may be an appropriate means of coping with such internal barriers if environmental educators handle such issues consciously and carefully (Dräger \& Vogt, 2007).

Agriculture-related nature experiences are crucial to fostering agricultural interests. Therefore, both teachers and parents should provide opportunities for significant agriculture-related nature experience (e.g., via farm education programs). Teachers should benefit from the positive interrelations among agricultural knowledge, agriculture-related nature experience, and agricultural interests to support the overall aim of "Gestaltungskompetenz" as the German approach to education for sustainable development (de Haan, 2006). A combination of curricular and extracurricular education focusing on agricultural issues can allow for deeper and more experiencebased insights into the importance of agriculture for a sustainable future. 


\section{The Potential of School Farms to Foster Students' Interests in Agriculture: Animals Attract Girls and Hands-on Engages Boys? ${ }^{15}$}

\subsection{Abstract}

Farm education aims to (re)connect young people to agriculture via Education for Sustainable Development. However, research has hardly provided evidence that school farms foster agricultural interests. In this study, a weeklong residential school farm program with agricultural work experiences increased agricultural interests across German fifth and sixth graders $(n=799)$ compared to a control group without any special treatment $(n=201)$. The results revealed gender differences: Girls' interest only increased in animal husbandry, boys achieved interest gains in animal husbandry, arable farming, vegetable and fruit cropping, and primary food processing. The genderspecific results are discussed, and implications are drawn for research and educational practice.

Keywords: agriculture, school farm, interest, hands-on, gender, education for sustainable development

\subsection{Introduction}

\subsubsection{Agricultural and Farm Education}

Agricultural education can be broadly understood as teaching and learning about agriculture. This strand of education became of importance in formal educational settings through new and more elaborated farming methods caused by the initiating industrial revolution (Hillison, 1998). In the second half of the twentieth century, agricultural production became increasingly mechanized and intensified tremendously. The structural change in agriculture came along with a rapid decrease of the agrarian working population that, e.g., decreased from almost $40 \%$ in 1895 to $2 \%$ in the first decade of the 21st century in Germany (DBV, 2013, p. 20). Due to the higher complexity of modern production methods, agricultural education shifted towards more specified approaches focusing on vocational training and university education while agricultural content was incrementally reduced in the regular school system. As a consequence of the mentioned developments, today, in particular young people have little contact with agriculture.

Farm education or farm-based education is one approach that evolved throughout the past decades in order to reconnect young people with agriculture and primary food

\footnotetext{
${ }^{15}$ Source: Bickel, M., Strack, M., \& Bögeholz, S. (resubmitted). The potential of school farms to foster students' interests in agriculture: Animals attract girls and hands-on engages boys?
} 
production. In contrast to the general concept of agricultural education that is neither bound to a place of learning nor to a certain way of learning, farm education is based on practical experience-based learning on farms. During the past decades, several farms in the United States and Europe started to offer educational activities as one conceptual approach to multifunctional agriculture (Renting et al., 2009). By diversifying their core functions beyond the production of food and other natural commodities, socalled educational farms strive for an alternative farming model. In the United States, the increasing importance of agriculture and food production in educational settings is reflected in initiatives such as the National Farm to School Network (www.farmtoschool.org), the Farm-Based Education Network (www.farmbasededucation.org), and a growing school garden movement (Blair, 2009). In Europe, many different farm education concepts exist (Schockemöhle, 2011) and get organized in networks of practitioners and researchers such as the national working group of educational farms in Germany (Bundesarbeitsgemeinschaft Lernort Bauernhof e.V., www.baglob.de).

This development mirrors that the farm as an "arena for learning" (Krogh \& Jolly, 2012 , p. 5) is becoming increasingly important. The importance for agriculture as a context and farms as a place of learning has several reasons. In general, learning about agriculture on farms provides many favorable learning features: the farm as learning environment is a real, authentic setting and all tasks are connected with the overarching topic of food production that is of immediate importance for the learners (Knobloch, Ball, \& Allen, 2007). Regular farm jobs such as the cultivation of crops may foster a connection with nature. This is relevant because nature experiences are deemed crucial for human development in manifold ways (e.g., cognitive, emotional, and physical development; see Gebhard, 2013). Caring for farm animals may help to establish a relationship with animals and induce awareness for animal welfare. The importance of caring for living organisms is immediately tangible and comprehensible, in that the learners are confronted with "real" tasks that "call on us to be done" (Krogh \& Jolly, 2012, p. 2).

German science education curricula of all kinds of schools and for all ages include manifold agricultural content in particular within biology and geography curricula (Bickel \& Bögeholz, 2013a; Matz, 2008). Key aspects center on crop plants and domestic animals (in particular animal welfare), environmental impacts of human intervention in ecosystems and natural landscapes (e.g., climate change, erosion, and the loss of biodiversity), as well as environmentally and socially acceptable economic strategies (e.g., organic vs. conventional farming systems; Bickel \& Bögeholz, 2013a). However, agriculture is often only one possible option or a recommended topic to work on given competencies or thematic suggestions (such as nature protection or globalization). 
Thus, the inclusion of agricultural content in the classroom depends on the teacher to a large degree.

Besides the mentioned curricular links, the importance of farm education is accentuated because agriculture offers many points of reference for an Education for Sustainable Development (ESD). It is closely related to core issues of sustainable development such as the loss of biodiversity and climate change (Bickel \& Bögeholz, 2013b; Woodhouse, 2010). The current form of intensive agricultural production threatens biological diversity through factors such as the transformation of natural habitats in agricultural land, the intensive use of pesticides and chemical fertilizers, or the use of few high-performance breeds in animal and plant production (e.g., Geiger et al. 2010; MEA, 2005). The earth's climate is tremendously affected by agriculture that causes approximately $13.5 \%$ of the worldwide greenhouse gas emissions caused by man according to estimates of the Intergovernmental Panel on Climate Change (IPCC; Pachauri \& Reisinger, 2007).

But also the way of learning in farm education corresponds to ESD. In general, extracurricular learning is deemed suitable for ESD, in particular in real-world learning environments such as farms. The farm as place of learning is appropriate to convey the concept of sustainability because it provides a cross-discipline context including ecological, economic, and social aspects and offers a complex learning environment addressing cognitive and practical competencies. Learning on farms addresses subcompetencies of "Gestaltungskompetenz" (shaping competency), which is the central long-term goal of ESD (see de Haan, 2010). The practical hands-on approach is closely related to the holistic, action-oriented learning paradigm of ESD. Working on tasks such as options for shaping land (e.g., a vegetable patch) or a comparison of realistic agricultural policy options (e.g., organic vs. conventional agriculture) train decision-making competencies (Dreyfus, 1987). Such tasks directly link to the ability to take part in societal designing and decision making processes being one overarching aim of ESD. In addition, the ability to plan and act individually and with others is addressed.

Many farm jobs cannot be solved individually and thus require cooperative learning methods fostering teambuilding and social competencies. Moreover, many farm experiences and specifically the close contact with farm animals often trigger ethical discussions on nutritional behavior and meat consumption (see Bickel, 2006). This links to the ability to reflect upon one's own principles and values and those of others (see de Haan, 2010).

Summing up, the farm as an extracurricular place of learning seems suitable to confront students with agriculture in a way that corresponds to curricular requirements 
and ESD. One core aim of farm education is to counteract the lost societal bonds to rural life and primary food production in industrialized countries (for further reading see Bickel, Strack, \& Bögeholz, 2014). This is particularly crucial in light of the mentioned sustainable development challenges that are closely related to agricultural production. From an educational point of view, a reconnection with agriculture can be accomplished through the cultivation of an interest in agriculture. The purpose of this paper is to scrutinize whether educational interventions on school farms succeed to foster students' interests in agriculture-an issue that has not been tackled by prior research.

\subsubsection{Prior Research on the Effectiveness of Farm Education}

In general, there is yet little empirical evidence concerning outcomes of farm education programs and related approaches. Based on their observations, made over 15 years, and their experience in practical farm and gardening education in Norway, Krogh and Jolly (2012) describe motivational changes as positive outcomes that foster a "will to act" (p. 2) across participants. Similarly, most participants expressed positive opinions regarding their experiences and learning outcomes towards an agriculture-related outdoor learning program in Finland (Smeds, Jeronen, Kurppa, \& Vieraankivi, 2011).

A literature review on benefits of school gardens ${ }^{16}$ reported that some quantitative studies found that school garden activities improve science achievement and food behavior (Blair, 2009). However, the author of this study raised validity and reliability issues. Qualitative findings suggested improved motivation in related subject areas, such as plants, ecology, and nutrition, through school gardening activities (Blair, 2009).

Lekies and Sheavly (2007) scrutinized factors of a school garden project that influenced 9- and 10-year-old children's interest in gardening. Learned gardening skills (planting, caring, application of tools, and pest control) were the strongest predictor for interest in gardening $(\beta=.39, p<.01)$. Hence, it can be assumed that hands-on garden activities foster related interest. However, real changes in interest were not monitored because a post-test-only design was applied.

The mentioned studies suggest a great potential of farm education concerning motivational variables. Yet, thorough quantitative evaluations concerning the potential to foster agricultural interests are lacking.

${ }^{16}$ Strictly speaking, school gardens do not refer to farm education. However, they provide similar learning opportunities and nature experience. For this reason, research findings on school garden outcomes are included in this section. 


\subsubsection{The Person-Object-Theory of Interest}

As mentioned above, a connection of (young) people with agriculture can be reached through fostering agricultural interests. According to the Person-Object-Theory of interest (Krapp, 2002, 2005) an interest is object-specific by definition. It denotes a certain type or quality of an individual's relationship with a particular object. Characteristics of interest comprise cognitive and emotional aspects that represent positive affective reactions and personal meaningfulness attributed to the object of interest. From an educational perspective, it is valuable because it characterizes a rather persistent personal predisposition to repeatedly reengage in a particular content, matter, or activity (i.e., the interest object). Interest facilitates learning processes, selfregulated learning, and intrinsically motivated engagements with the interest object (Hidi \& Renninger, 2006). Outdoor education research has found program duration and hands-on learning to have a bearing on interest as will be outlined by the following two sub-sections.

\subsubsection{Program Duration as a Success Factor Concerning Interest and Behavioral Intentions in Outdoor Education}

There is empirical evidence that extracurricular interventions can have positive effects on different cognitive and affective variables such as interest (see Dillon et al., 2006). Research suggested that program duration is one success factor. Short-term treatments seem to be inappropriate (e.g., Bittner, 2003), and even longer treatments do not guarantee success to increase individual interest ${ }^{17}$. This corresponds to the abovementioned Person-Object-Theory specifying interest as a rather stable parameter.

After an ecological unit of 14 lessons in school, interest in ecology could not be enhanced among eighth and ninth grade students (Randler \& Bogner, 2007). Stern, Powell, and Ardoin (2008) reported a significant increase in interest in learning about natural history and cultural heritage after 3 and 5 -day residential programs in a national park. However, the effect across the whole sample of 300 students from fourth through seventh grade was very small, according to Cohen's conventions $(d=.11)$. Students partaking in 5-day programs had significantly greater interest gains than students in 3 day programs $(p=.025)$.

With respect to other quite stable parameters, a weeklong outdoor education unit resulted in significant changes of behavioral intentions concerning the preservation and utilization of the environment across students from grades five to seven (Bogner \&

\footnotetext{
17 If not mentioned else, we refer to individual interest and not to the fluent emotional state described as situational interest (Hidi \& Renninger, 2006).
} 
Wiseman, 2004). Comparing two programs that differed in duration, behavioral intentions towards the environment were only affected by the extended program (Bogner, 1998; one day versus five days).

Summing up, the mentioned results indicate that interest is not easy to change. This is consistent with theoretical considerations describing interest as a relatively stable characteristic (Hidi \& Renninger, 2006). Thus, long-term treatments should be conducted.

\subsubsection{Hands-On Experience and Interest}

Besides the importance of program duration, hands-on activities appear appropriate to address both, the affective and the value-related component of interest according to the Person-Object-Theory of Interest. Concerning the affective component of interest, the preference for activities that involve learners physically and intellectually is widely acknowledged (Bergin, 1999; Mitchell, 1993). Active involvement triggers positive affective learner reactions that have been found to foster interest (Mitchell, 1993; Swarat, 2012).

In line with interest models highlighting the importance of active learner involvement for interest development (Mitchell, 1993), research findings have confirmed that handson activities are a success factor for outdoor learning and interest development (Carrier, 2009; Zelezny, 1999).

Daily experience in the garden (made possible by a home garden and occasional garden work) predicted agricultural interest $(\beta=.172, p<.001)$ and in particular the specific interest in vegetable and fruit cropping $(\beta=.139, p<.001)^{18}$ across students of grades five and six (Bickel, Strack, \& Bögeholz, 2014).

For interests within the context of biology education across sixth and seventh graders, the form of activity is more of a determinant than content topic and learning goals (Swarat, Ortony, \& Revelle, 2012). Holstermann, Grube, and Bögeholz (2010) suggested that typical hands-on activities have the potential to increase interests in biology education. However, not all hands-on activities promoted interest; but in particular activities related to plants were favorable. In addition, the quality of the hands-on experience was of importance, as indicated by significant correlations

\footnotetext{
18 The $\beta$ value has to be interpreted as additional to the score for general interest in agriculture because the interest in vegetable and fruit cropping was represented as one dimension of general interest in agriculture; thus, in predicting analysis, the ipsatized item scores were used (for more details see Bickel, Strack, \& Bögeholz, 2014).
} 
between the experienced quality of the hands-on experience and interest $(r=.44$ to .88; $N=141$ students from the $11^{\text {th }}$ grade).

Studies within an outreach laboratory teaching about gene technology found that hands-on experiments do not necessarily increase interest among 12th grade students (Scharfenberg, 2005). In this respect, a recent study suggested that learning through hands-on activities is favored by the integration of cognitive activities (such as group discussions, minds-on); not only in subsequent teaching phases, but also during the hands-on phase (Scharfenberg \& Bogner, 2013). With such an approach, mental effort (as an indicator of cognitive load) can be increased, which is assumed to improve motivation (Paas, Tuovinen, Merriënboer, \& Darabi, 2005). This notion is also consistent with the given interest conception: hands-on learning-especially in realworld learning environments-is closely connected with learners' everyday life. While hands-on learning is supposed to primarily address the affective component of interest (as mentioned above), the value-related component of interest is additionally activated if a cognitive integration of the emotional experience is warranted.

In summation, hands-on activities have great potential to increase both components of interests. However, they ought to be combined with reflective minds-on activities and it is important that they are experienced in a positive way.

\subsubsection{Gender-Specificity in Agricultural and Related Interests}

To date, there have been few studies focusing on agricultural interests. There is some empirical evidence that agricultural interests differ according to gender. Bickel, Strack, and Bögeholz (2014) found gender differences concerning four out of five agricultural content areas. Girls had greater interest in animal husbandry, vegetable and fruit cropping, and primary food processing, whereas boys showed higher interest rates for agricultural engineering.

Scrutinizing factors for interest in gardening after a school garden project, gender significantly influenced interest rates $(\beta=.25, p<.05)$, with girls having more interest than boys (Lekies \& Sheavly, 2007). Applying a post-test-only design, this study did not reveal whether the school garden program had different effects on the interests of girls and boys. The authors emphasized the importance of finding approaches that involve boys.

The gender differences support results on student interests in related domains: Girls tend to have greater interest in animals and boys in technical aspects (e.g., Hagay et al., 2013; Lindemann-Matthies, 2005). Concerning interest in plants, results do not clearly indicate a general difference according to gender (e.g., LindemannMatthies, 2005). 
These findings hint at a gender-specificity within agricultural interests. However, it is hardly known whether educational treatments on farms or related interventions have gender-specific effects.

\subsubsection{School Farms and their Potential to Foster Agricultural Interests}

The following paragraphs outline the concept of school farms that represents one specific approach to farm education that is part of our research. School farms offer residential farm stays, actively involving participants in the farmers' daily lives. School farms keep a variety of animal species and field and garden crops in order to represent a broad spectrum of agriculture, which can be an anchor for discussions on the importance of biodiversity issues. Typical tasks include taking care of animals (e.g., feeding, milking), activities in plant production (e.g., sowing, harvesting), and primary food processing (e.g., milk processing, baking bread). The diverse tasks offer a broad spectrum of nature experiences, e.g., social (caring for pets), scientific (e.g., exploring plants), or aesthetic nature experiences (experiencing the beauty of nature; for more details on the classification of nature experiences see Bögeholz, 2006). The addressed subjects often combine ecological, economical, and social dimensions in the spirit of ESD (Bickel \& Bögeholz, 2013b; Matz, 2008).

School farms meet many of the requirements that foster interest. They offer longterm residential farm stays (see Bogner, 1998; Stern et al., 2008) and follow a handson approach (see Swarat et al., 2012; Zelezny, 1999). To enable active involvement, participants work in groups of five to eight members on tasks that are designed to allow for a maximum of manual labor. The group work also aims at fostering participants' ability to cooperate (contributing to "Gestaltungskompetenz", de Haan, 2010, 320).

We suppose that the perceived quality of the school farm experiences (see Holstermann et al., 2010) is adequate because school farm conditions provide the requirements to meet participant needs for autonomy, competence, and social relatedness (for further reading see Deci \& Vansteenkiste, 2004). Moreover, the handson approach is supported by a cognitive minds-on component (see Scharfenberg \& Bogner, 2013). For instance, ethical discussions about meat consumption stem from the close contact to animals and the consumption of the farm products during the farm stay (Bickel, 2006). On the basis of such an experience the nutritional behavior of oneself and others can be reflected (referring to "Gestaltungskompetenz", de Haan, 2010, 320).

To date, it has not been analyzed whether farm education programs-and in particular school farms-succeed in fostering agricultural interests. 


\subsection{Objectives}

Based on previous research and the mentioned considerations concerning interestsupporting features of school farms, our aim was to evaluate whether a weeklong school farm program would increase student interest in agriculture and its content areas. In light of gender-specific interest domains, we further wanted to scrutinize whether the school farm program would impact the agricultural interests of girls and boys differently. If so, two opposite effects could be possible: The school farm program could primarily address existing interests and, thus, strengthen gender differences in agricultural interests; or it could balance gender-specific deficiencies and increase the interest i) of boys concerning animal husbandry, vegetable and fruit cropping, and primary food processing and ii) of girls concerning agricultural engineering (Bickel, Strack, \& Bögeholz, 2014).

\subsection{Methods}

\subsubsection{Participants and Procedure}

Participants were 43 school classes of fifth $(n=556)$ and sixth $(n=444)$ graders dispersed over 7 German federal states. The treatment group contained 35 school classes ( $n=799,410$ females and 386 males; 3 students did not indicate their gender), and the control group consisted of 8 school classes $(n=201,67$ females and 112 males; 22 students did not indicate their gender).

All participants filled pre- and post-test questionnaires. The first assessment was administered in the classroom. Approximately two weeks later, the treatment group participated in a weeklong residential school farm program. Students filled the post-test questionnaires at the end of the farm stay. Participants of the control group had regular school lessons without any special treatment. They filled the post-test questionnaires in the classroom in the same interval after the first survey as the treatment group did.

\subsubsection{The School Farm Program}

Five school farms collaborated in our research. Participants took part in the regular school farm program. The program engaged participants approximately four to six hours a day in different activities. Of course, agricultural works are subject to some seasonal fluctuations. However, many parts of the program are always offered, so that basic agricultural content areas such as animal husbandry, plant production, and primary food processing are always addressed. During the farm works all participants were supervised by the farm staff.

Experiences in animal husbandry included the preparation of fodder and the feeding of various farm animals (cows, pigs, sheep, hen, goats, horses, and rabbits), milking, mucking out the stable, or fencing pasture land. Gardening experiences relate to a great diversity of vegetable and fruit species and involved activities such as 
preparing vegetable beds, fertilizing, weeding, pest control, harvesting, and fruit picking. Experiences in primary food processing referred to tasks such as making jam or vinegar, backing bread and other pastries, as well as producing fresh juices.

\subsubsection{Measures}

\section{Dependent Variables:}

Interest in agriculture and its content areas was assessed with a 20-item instrument applying a factorial design with four structural components of interest and five agricultural content areas. The structural components of interest trace back to Schiefele and Krapp (1996) and rest upon the outlined interest conception of the Person-Object-Theory including feeling and value-related components of interest (Krapp, 2005). They are verbalized as bipolar adjectives on a 4-point rating scale. An exemplary item is "When I deal with [animal husbandry], I am bored (1) / interested (4)." The agricultural content areas include animal husbandry, arable farming, vegetable and fruit cropping, primary food processing, and agricultural engineering. According to the factorial design, each agricultural content area was measured with four items. The instrument had been developed and validated in previous studies on the basis of exploratory and confirmatory factor analyses (Bickel \& Bögeholz, 2013b; Bickel, Strack, \& Bögeholz, 2014).

Besides investigating interest in the agricultural contents areas, the instrument can be used to assess general interest in agriculture as a mean score of all 20 applied items $\left(\alpha_{\text {pre }}=.91, \alpha_{\text {post }}=.91\right.$ ) because confirmatory factor analysis findings indicated a general factor (Bickel, Strack, \& Bögeholz, 2014). The five content areas indicated good reliabilities $(\alpha>.90)$.

\section{Independent Variables:}

To analyze the effect of the school farm treatment on students' agricultural interests, two independent variables were applied. The variable labeled 'School Farm Treatment' distinguished the treatment group (coded +1 ) and the control group (coded -1$)$. While the treatment group gained the five-day intervention on the school farm, control group members attended the regular instruction in school that was not related to agriculture.

Beyond the global effect of participation on a school farm, we investigated whether the individual work experience on the school farm had an effect on students' interests because students' active experience on the farm varies. The 'work experience' variables distinguished students with and without active work experience in different agricultural contents areas. In the post-test questionnaire, students recorded key words of their daily activities on the farm, so we could identify their hands-on work experience in animal husbandry (animal experience), vegetable and fruit cropping (gardening experience), and primary food processing (processing experience). Students were not allowed to operate farm machinery and could hardly take an active part in arable 
farming activities. Accordingly, we did not include work experience variables for these two content areas.

Students who gained work experience in the respective content area during the farm stay scored +1 , those without experience scored -1 , and participants of the control group scored 0 , in order to avoid multicollinearity with the school farm treatment score.

Thus, for the three concerned agricultural content areas, we could differentiate between the effect of the treatment as a whole and the actual work experience in the respective content area.

As a work experience predictor for general agricultural interest, we created a variable that added the three assessed experience scores to an overall score (farming experience). Gender did not affect whether students gained work experience (all $p>$ $.10)$.

\subsubsection{Data Analysis}

To explain post-test scores of interest, we conducted hierarchical regression analyses for general interest in agriculture and interest in each agricultural content area. Because interest is known to be relatively stable (Krapp, 2005), we entered students' initial interest in the first step.

In step 2, school farm treatment was inserted to test whether the global school farm treatment lead to an increase in agricultural interests among participants of the experimental group in contrast to control group members. To check whether participants with low initial interest benefited in particular from the treatment, interaction of the school farm treatment with the respective initial interest score was considered.

Finally, where applicable, the work experience variable and the interaction of the work experience with initial interest were included (step 3). Thus, we could find out whether the actual engagement in farm jobs related to the content areas further increased the interest beyond the effect of the global school farm stay. In order to avoid multicollinearity, all predictors were z-transformed before they were multiplied to gain interaction scores (Aiken \& West, 1993).

To investigate gender-specific effects, the same analyses were conducted for girls and boys separately ${ }^{19}$.

\footnotetext{
${ }^{19}$ In the first analyses we included gender and all its interactions in a fourth step with a lot of interactions emerging as significant. To reduce complexity, we decide to report an overall analysis without the gender terms as well as separate analyses for each gender group.
} 


\subsection{Results}

Throughout all results, the initial interest strongly predicted the interest scores after the school farm stay $\left(R^{2}=.26-.49\right)$, showing the relative stability of the interest measure.

\subsubsection{Global Effects of the School Farm Treatment and Work Experiences}

The regression analyses with the whole sample $(N=1,000)$ showed effects of the school farm treatment $(\beta=.084, t(994)=3.60, p<.001)$ and farming experience $(\beta=$ $.090, t(994)=3.93, p<.001)$ on interest in agriculture.

Regarding the content areas, interest in animal husbandry $(\beta=.148, t(994)=5.99$, $p<.001)$, arable farming $(\beta=.062, t(996)=2.52, p=.012)$, and primary food processing $(\beta=.059, t(992)=2.23, p=.026)$ increased as a result of the school farm treatment. Concerning the former two, participants with low initial interest especially benefited from the school farm treatment because interaction effects between the initial interest and the school farm treatment emerged with a negative sign (animal husbandry: $\beta=-.109, t(994)=-4.38, p<.001$; arable farming: $\beta=-.050, t(996)=-2.04$, $p=.042)$.

Gardening experience increased the interest in vegetable and fruit cropping ( $\beta=$ $.094, t(991)=3.68, p<.001)$. Also the interest in animal husbandry $(\beta=.066, t(994)=$ 2.71, $p=.007)$, and primary food processing $(\beta=.078, t(992)=2.95, p=.003)$ profited from the respective work experience. Participants with lower initial interest became more interested in animal husbandry if they actively worked with animals; this was marked by a significant interaction effect $(\beta=-.089, t(994)=-3.62, p<.001)$.

Student interest in agricultural engineering was not significantly increased by the school farm treatment $(\beta=.038, t(995)=1.66, p=.098)$.

Summarizing the findings for the whole sample, the school farm treatment and the work experience in the respective content areas fostered agricultural interests. It has to be noted that the standardized regression coefficients remained slightly below .10, in most instances. Hence the effects are rather small.

\subsubsection{Gender-specific Effects}

In the subsequent analyses, we investigated gender-specific effects (Table 8.1). Concerning the general interest in agriculture, girls neither profited from the school farm treatment nor from the particular work experience on the farm. In contrast, both predictors qualified for boys' general interest in agriculture.

The results of content area interests also differed according to gender. Girls' interest only increased in animal husbandry if they really worked with animals. This applied especially to girls with comparatively lower initial interest in animal husbandry. All other agricultural interests of the female participants were not enhanced. 
Noticeably, boys' interest increased regarding four out of five content areas. Their interest in animal husbandry and arable farming was enhanced by the school farm treatment, particularly if their initial interest had been comparatively low. Their interest in vegetable and fruit cropping was also enhanced by the school farm treatment and their work experience in gardening. The interest in primary food processing was augmented for those who worked in this field during the farm stay. An increase in interest in agricultural engineering just failed statistical significance $(\beta=.069, t(1.92)=$ $1.92, p=.056)$. 
Table 8.1: Gender-specific agricultural interests after the school farm stay as a function of initial interest (control variable, step 1), school farm treatment and its interaction with initial interest (step 2), and work experience on the school farm in the respective content areas and their interaction with initial interest (step 3, not applicable to arable farming and agricultural engineering)

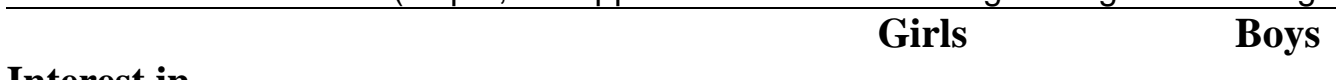

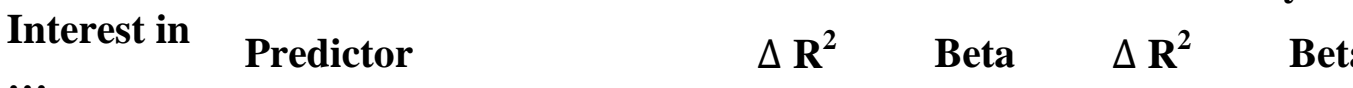

\begin{tabular}{|c|c|c|c|c|c|}
\hline \multirow{8}{*}{$\begin{array}{l}\text { Agriculture } \\
\text { (general) }\end{array}$} & Step 1: & .483 & & 464 & \\
\hline & Initial interest & & .694 & & .644 \\
\hline & Step 2: & .001 & & $.024^{* * *}$ & \\
\hline & School farm treatment, ME & & -.016 & & $.143^{* * * *}$ \\
\hline & School farm treatment, IA & & .024 & & -.045 \\
\hline & Step 3: & .005 & & $.015^{* *}$ & \\
\hline & Farming experience, $\mathrm{ME}$ & & .055 & & $.122^{* * *}$ \\
\hline & Farming experience, IA & & -.049 & & -.011 \\
\hline \multirow{8}{*}{$\begin{array}{l}\text { Animal } \\
\text { husbandry }\end{array}$} & Step 1: & .260 & & .335 & \\
\hline & Initial interest & & 493 & & .530 \\
\hline & Step 2: & .000 & & $.060^{* * * *}$ & \\
\hline & School farm treatment, ME & & .007 & & $.194^{* * *}$ \\
\hline & School farm treatment, IA & & -.023 & & $-.105^{* *}$ \\
\hline & Step 3: & $.040^{* * * *}$ & & $.010^{*}$ & \\
\hline & Animal experience, $\mathrm{ME}$ & & $.174^{* * *}$ & & .030 \\
\hline & Animal experience, IA & & $-.170^{* * *}$ & & $-.087^{*}$ \\
\hline \multirow{5}{*}{$\begin{array}{l}\text { Arable } \\
\text { farming }\end{array}$} & Step 1: & .493 & & .362 & \\
\hline & Initial interest & & .711 & & .575 \\
\hline & Step 2: & .003 & & $.026^{* * *}$ & \\
\hline & School farm treatment, ME & & -.048 & & $.131^{* * *}$ \\
\hline & School farm treatment, IA & & -.036 & & $-.079^{*}$ \\
\hline \multirow{8}{*}{$\begin{array}{l}\text { Vegetable } \\
\text { and } \\
\text { fruit } \\
\text { cropping }\end{array}$} & Step 1: & .355 & & .311 & \\
\hline & Initial interest & & .610 & & .543 \\
\hline & Step 2: & .008 & & $.017^{* *}$ & \\
\hline & School farm treatment, ME & & -.072 & & $.100^{*}$ \\
\hline & School farm treatment, IA & & -.053 & & -.058 \\
\hline & Step 3: & .001 & & $.027^{* * *}$ & \\
\hline & Gardening experience, ME & & .027 & & $.151^{* * * *}$ \\
\hline & Gardening experience, IA & & .005 & & -.058 \\
\hline \multirow{8}{*}{$\begin{array}{l}\text { Primary } \\
\text { food } \\
\text { processing }\end{array}$} & Step 1: & .260 & & 286 & \\
\hline & Initial interest & & .503 & & .519 \\
\hline & Step 2: & .005 & & .009 & \\
\hline & School farm treatment, ME & & .062 & & .038 \\
\hline & School farm treatment, IA & & .031 & & -.076 \\
\hline & Step 3: & .001 & & $.015^{* *}$ & \\
\hline & Food proc. experience, ME & & .032 & & $.100^{* *}$ \\
\hline & Food proc. experience, IA & & -.009 & & -.054 \\
\hline \multirow{5}{*}{$\begin{array}{l}\text { Agricultural } \\
\text { engineering }\end{array}$} & Step 1: & .394 & & 410 & \\
\hline & Initial interest & & .626 & & 629 \\
\hline & Step 2: & .001 & & . 004 & \\
\hline & School farm treatment, ME & & .030 & & .069 \\
\hline & School farm treatment, IA & & .007 & & -.006 \\
\hline
\end{tabular}

Note: $\mathrm{ME}=$ Main effect, IA $=$ interaction effect; ${ }^{*} p<.05,{ }^{* *} p<.01,{ }^{* *} p<.001$ applied to step 2 and 3. 


\subsection{Discussion}

This study investigated whether a five-day school farm intervention that provides hands-on activities and is closely linked to ESD and the acquisition of Gestaltungskompetenz could foster agricultural interests in German fifth and sixth graders. As expected, the school farm intervention and the actual work experiences increased agricultural interests among the students of the treatment group compared with the control group. Thus, our results advocate the benefits of extended ESD interventions in order to foster rather stable constructs such as individual interest.

The results particularly emphasize the importance of work experiences on the farm because they consistently qualified in all analyses that included the whole sample. Yet the effects concerning the whole sample were rather small, due to the genderspecificity that will be discussed in the following paragraphs.

In our study, female participants only increased their interest in animal husbandry if they worked with animals on the farm. The other interest areas of girls were neither affected by the school farm treatment nor by the work experiences. In contrast, boys' agricultural interests seemed to be better addressed than girls' interests. The school farm treatment and the work experiences increased male participants' interests concerning agriculture and nearly all investigated content areas.

From an instructional point of view, it is very valuable that school farms address boys' interests, in particular during a phase of life in which most academic interests decrease (Prenzel, 1998). Previous research has suggested that girls have more academic interests than boys, particularly regarding animals (Hagay et al., 2013) but also regarding agriculture and gardening (Bickel, Strack, \& Bögeholz, 2014; Lekies \& Sheavly, 2007). Our results show that school farms may decrease prior gender differences concerning animal husbandry, vegetable and fruit cropping, and primary food processing. Only the pre-existing difference regarding interest in agricultural engineering in favor of boys was reinforced by trend.

The question arises: Which factors determine the gender-specific effects found? We assume that different factors of the school farm experiences are attractive to boys and girls. Apparently, caring for farm animals plays a particular role for girls. Presumably, most girls can establish an emotional relationship with the farm animals they work with-which can be seen as a social nature experience according to the classification of Bögeholz (2006). In matters of the Person-Object-Theory, this relationship is likely to address the affective component of interest in terms of "empathic content-specific emotional experiences" (Krapp, 2002) and thus may contribute to interest development. Bögeholz' (2006) studies also reflect the particular role of social nature experiences for girls who tend to appreciate such experiences stronger than boys. Appreciation is closely linked to personal values (Bögeholz, 2006) 
and thus also to the value-related component of interest according to the PersonObject-Theory (Krapp, 2002). Thus, caring for farm animals was likely to address feeling and value-related components of girls' interest in animal husbandry in our study.

Since boys increased their interest in almost all agricultural content areas, there seems to be something more general of the school farm experience that appeals to boys. The results suggest that the hands-on approach of the school farm specifically fosters the interest of boys because the work experiences increased male interests in agriculture, vegetable and fruit cropping and primary food processing. Carrier (2009) found similar gender-specific patterns comparing two groups in an environmental education program with indoor (control group) and outdoor learning (treatment group with special emphasis on hands-on activities): Boys took greater advantage of the hands-on outdoor treatment with respect to gains in knowledge, attitudes, behavior, and comfort levels. However, research findings do not consistently suggest that handson activities in general favor boys. In a science education class, the confidence levels of girls were stronger enhanced than those of boys by a hands-on designing task of a mechanical device (Klahr, Triona, \& Williams, 2007).

Given the findings of Holstermann et al. (2010) that showed the perceived quality of hands-on tasks to be relevant for interest, it appears reasonable to give closer inspection to the specific quality of the hands-on tasks on school farms and to consider how this particular quality relates to our gender-specific results. One specificity of school farms is that participants are involved in the actual operating procedure of the agricultural enterprise. School farm tasks engage participants with real-life objects, i.e., plants, animals, agricultural tools, and machinery. Tasks such as weeding, fencing, and in general applying tools such as hay forks, spades, or hoes are common school farm jobs. These jobs-and in general most activities on school farms-are physically challenging and require body strength. The kinesthetic learning on school farms stands out from common hands-on tasks in science education.

Gender-oriented research gives indication that this characteristic might be an explanation for the gender-specific results of our study: Males seem to cope better with instructional methods that involve physical activity and allow for kinesthetic learning in a hands-on manner (King \& Gurian, 2006). By contrast, girls are more likely to display traits that suit classroom conditions, such as diligence, self-regulation, and selfdiscipline (e.g., Duckworth \& Seligman, 2006; Matthews, Ponitz, \& Morrison, 2009). Furthermore, Maguire (1998) found variations in perceptions of individual fitness levels and the fitness required for fieldwork tasks. Both aspects were favored by males, which in turn had an influence on their enjoyment of physically demanding tasks. Because physically demanding hands-on activities are at the core of most school farm tasks, they might be a key element to foster boys' interests. This may hold in particular for boys at the age of 10 to 12 . This developmental phase is characterized by great gains 
of physical strength (Malina, Bouchard, \& Bar-Or, 2004 ) and school farms-in contrast to daily school life-seem to offer adequate opportunities to make use of this potential. Yet, it has to be emphasized that the hands-on tasks on school farms are framed in a meaningful learning context (i.e., food production) accompanied by reflective minds-on activities. This dedicated holistic approach, which largely corresponds to ESD, seems to be successful in promoting interests.

The explanation for the gender-specific results could as well originate from further differences in perceptions concerning the quality of the school farm program and hands-on experience (Holstermann et al., 2010). The perceived quality may be influenced by process-oriented variables such as situational interest or autonomy, competence, and social relatedness (Deci \& Vansteenkiste, 2004).

Finally, it should be noted that we do not want to argue that school farms only support boys' learning. This study proved that school farms fostered mainly boys' agricultural interests. However, it is possible that girls could take advantages concerning other ESD-relevant outcomes that were not monitored in this study (e.g., cognitive gains).

\subsection{Limitations}

Further explanations of the development of agricultural interests during a school farm program could be achieved by considering three conditions on the farms.

i) Differences between farms: Due to the initial arrangements with the farms, we neither took a closer look at differences between farm conditions (e.g., domesticated animals and plants, precise instructional approach) nor differentiated the results between the five participating farms.

ii) Differences within farms: School farm programs are subject to seasonal variations and weather changes. However, some parts of the program are offered every week (e.g., milking, feeding animals). Moreover, we introduced the work experience variables in order to consider participants' actual hands-on experience.

iii) Tutor effects: Tutor effects due to the personality and teaching style of the farm staff cannot be excluded. It is well known that teachers serve as role models and aspects such as their motivation, expertise, teaching strategies, and personal support can influence student interests (Osborne, Simon, \& Collins, 2003).

Summing up, this study did not consider qualitative aspects of the school farm program and related hands-on activities. Regarding the three mentioned limitations such information could help to further explain the results; e.g., concerning questions such as: (To what extent) do the programs on the farms and the degree of active learner involvement differ and how do such differences affect interest development? (How) do the tutors on the farm support participants' feelings like social well-being or 
competence (that are known to foster interest according to self-determination-theory; e.g., Minnaert et al., 2007) during the farm works? (To what extent) do (male and female) tutors serve as role models and does this affect learners' interests?

\subsection{Implications and Perspectives}

School farms contribute to foster student interests in agriculture, at least with a small effect and especially for boys. Hence, school farm experiences can contribute to meet the increasing need for boy-friendly teaching strategies.

This first systematic investigation concerning school farm effects could be a prerequisite for more complex models. Future research should consider the mentioned methodological limitations and aim to explain the school farm conditions. Technically speaking, this would require a more elaborate data analysis technique. Multi-level modeling would be appropriate: Farm characteristics operate on the farm level, seasons and school preparation on the level of the classes, initial interest, gender, and work experiences on the level of the individuals, with individuals nested in classes, and classes nested in farms. Moreover, interrelations of individual interest with processoriented measures-such as situational interest and the perceptions of autonomy, competence, and social relatedness during the farm works-could be added, along with qualitative concept evaluations and observations of the farm conditions, to triangulate and validate the quantitative results.

Concerning educational practice, teachers who are confronted with low student interest in science and agricultural subjects-particularly respective boys-should integrate hands-on outdoor units in their syllabus of instruction in combination with minds-on activities at school. Outdoor interventions of several days should be taken into consideration, in particular if they follow a holistic approach in the sense of ESD. School farms offer such interventions with combined kinesthetic hands-on learning and reflective minds-on activities in a meaningful context. This was shown to develop student interests and may facilitate learning in school. Given the gender-specificity concerning agricultural interest and the effects of school farm programs, a challenge is to develop diversity-sensible teaching methods. This applies to ESD-research, to educational practitioners in schools, and to extracurricular ESD applied on school farms. 


\section{A Model of Interest Development for Combined Extracurricular and In-school Interventions: Situational Factors and the Interplay of Situational and Individual Interest ${ }^{20}$}

\subsection{Abstract}

This intervention study with four measurement points investigates situational and individual interest in agricultural learning. German fifth and sixth grade students $(\mathrm{N}=$ 209) conducted a five-day hands-on program on a school farm and engaged in agricultural content during a consecutive in-school learning unit. The farm intervention increased agricultural interest. The intervention in school maintained increased interest levels, which, however, dropped at the follow-up. The results proved that participants' situational interest in working on the farm was influenced by perceived autonomy, social relatedness, and especially competence. A comparison of three variants of a learning unit showed that a combination of catch and hold elements fosters situational interest in the learning unit more than variants with only catch or hold elements. Reciprocal influences of situational interest and individual interest were documented. Our study proposes a model of interest development for combined extracurricular and in-school learning. It complements research concerning sources of situational interest.

Keywords: interest development, intervention study, situational interest, agriculture, extracurricular education

\subsection{Introduction}

Recent contributions to instructional interest research have increasingly tackled the question of how interest develops over time and what classroom conditions attract learners' interest. Theory suggests that situational interest is sparked by external triggers at its first occurrence (Schiefele, 2009). Perceptions of autonomy, competence, and social relatedness have been found to be important predictors of situational interest (Minnaert, Boekaerts, \& Brabander, 2007). In addition, there is evidence that instructional elements trigger ('catch') and maintain ('hold') situational interest (Mitchell, 1993). Models of interest development suggest that repeated occurrences of situational interest may lead to a longer lasting individual interest towards an object (e.g., Hidi \& Renninger, 2006; Krapp, 2002). Additionally, recent findings have also indicated that prior individual interest has a bearing on the emergence of situational interest in concrete learning contexts (e.g., Tsai, Kunter, Lüdtke, Trautwein, \& Ryan, 2008). As

20 Source: Bickel, M., Strack, M., \& Bögeholz, S. (resubmitted). A model of interest development for combined extracurricular and in-school interventions-Situational factors and the interplay of situational and individual interest 
such, Linnenbrink-Garcia et al. (2010) suggested reciprocity between individual interest and situational interest.

In this study, first, we gathered models and theories on situational interest and individual interest development. Second, we operationalized the resulting constructs in a hands-on agricultural learning context that combines extracurricular and in-school learning. This combined approach was chosen because extracurricular learning appears to be more effective in maintaining interest when integrated into the classroom than single interventions without follow-up activities in school (Dillon et al., 2006). This is also consistent with theory on interest development suggesting repeated learning occurrences (Hidi \& Renninger, 2006). However, intervention studies that document increased interest in the medium term are lacking, especially studies focusing on science education and education for sustainable development (cf. Holstermann, Ainley, Grube, Roick, \& Bögeholz, 2012; Randler \& Bogner, 2007). Agriculture was chosen as the context because of its relevancy to science education and education for sustainable development (Bickel, \& Bögeholz, 2013b; Poudel et al., 2005). For instance, agriculture is closely linked to sustainable development issues of the 21 st century such as the loss of biodiversity or climate change (e.g., Pachauri \& Reisinger 2007; Rockström et al., 2009).

This study analyzed students' individual interest development over a period of 10 weeks. The data were interrogated to determine whether a school farm stay and a subsequent learning unit in school resulted in increased interest levels. The subjective experience of basic need fulfillment (Ryan \& Deci, 2000) while working on the farm was supposed to address situational interest during the farm intervention. The integration of instructional facets to catch and hold situational interest (Mitchell, 1993) into the following learning unit in school was hypothesized to arouse situational interest during the second intervention. Combining different branches of interest research, a model of interest development for combined extracurricular and in-school learning is suggested.

\subsubsection{Individual and Situational Interest}

Interest promotes many positive aspects of learning such as attention, learning goals, and self-regulated learning (Hidi \& Renninger, 2006). Many studies in different contexts have shown a positive relationship between interest and academic achievement (e.g., Harackiewicz, Durik, Barron, Linnenbrink-Garcia, \& Tauer, 2008; Randler, Khambari, Moses, Luan, \& Simsek, 2009).

The person-object-theory of interest (Krapp, 2002, 2005) characterizes interest as a specific relationship between an individual and an object. This object can be a specific matter (e.g., plants), an activity (e.g., sowing), or a subject area (e.g., gardening). According to this definition, interest has emotional and value-related components. The former indicates a positive affective reaction to the interest object and engagements 
with it. The value-related attribute denotes a personal significance of the object. By definition both attributes of interest are intrinsic and thus directly linked to the object of interest, disregarding its relations to other objects (Schiefele, 2009).

Two types of interest are commonly distinguished: Individual interest is a relatively stable personal predisposition that persists over time. It involves the will to repeatedly deal with the interest object, either through concrete hands-on actions or through abstract mental activities. In this manner, individual interest is both a predisposition for learning processes and a long-term target of instruction (Renninger \& Hidi, 2011). Situational interest is a transient psychological state of interestedness in a current engagement. It can be directly influenced by external stimuli of the learning environment. Situational interest is crucial in concrete learning situations because it typically involves affective reactions, such as curiosity and enjoyment, but also cognitive processes as focused attention and increased cognitive functioning (Ainley \& Ainley, 2011; Hidi \& Renninger, 2006). Prominent models of interest development recognize two phases of situational interest based on a temporal dimension, namely the first occurrence, or triggered situational interest, and maintained situational interest (Hidi \&Renninger, 2006; Krapp, 2002). This distinction was also considered by Mitchell (1993), who examined instructional elements that are suitable to either catch or hold situational interest (cf. section 1.3.1). Based on confirmatory factor analyses, Linnenbrink-Garcia et al. (2010) recently provided empirical evidence in a mathematical context that situational interest and individual interest are highly correlated but nevertheless represent separate constructs.

\subsubsection{Individual Interest Development}

Several studies have shown that extracurricular environmental education programs have the potential to foster rather stable characteristics, such as individual interest, which makes longer residential interventions superior to shorter trips (Stern et al., 2008). There is evidence that the effects of outdoor learning are enhanced if the experiences are accompanied by preparatory or subsequent activities in school (Dillon et al., 2006). Holstermann et al. (2012) suggested that increases in individual interest are not likely to remain in the medium term after an extracurricular intervention that is not systematically integrated into school. Follow-up activities are important to establish links between experiences in the somewhat unfamiliar outdoor education settings and daily life in school and at home (Uzzell, Ruthland, \& Whistance, 1995).

Researchers who drafted models of interest development recommended that repeated occurrences of situational interest facilitate individual interest and its development (Hidi \& Renninger, 2006; Krapp, 2002). In this context, the four-phase model of Hidi and Renninger (2006) distinguished between an emerging and a well-developed individual interest (besides the two phases of situational interest mentioned in section 1.1). Thus, 
in learning contexts, situational interest is an immediate instructional target with the ultimate goal of fostering individual interest (Figure 9.1).

Guthrie et al. (2006) reported evidence that an increasing number of stimulating tasks can increase individual interest in reading among elementary students. Hands-on tasks, such as science observations and experiments, were supposed to increase situational interest. However, a direct measure of situational interest was not provided.

Randler and Bogner (2007) measured situational interest three times across 490 eighth and ninth graders during an

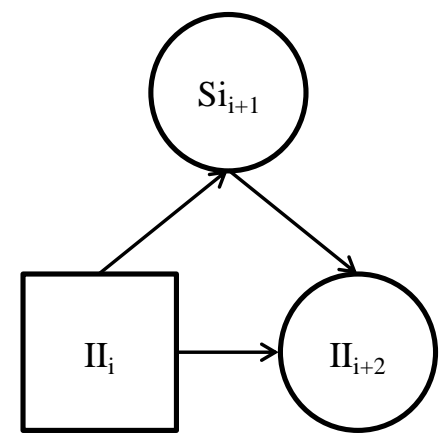

Figure 9.1: Interrelations of situational and individual interest $(\mathrm{SI}=$ situational interest, II = individual interest ecological unit comprising 14 lessons. The mean score of the three situational interest measures influenced the post-treatment individual interest in ecology $\left(\eta^{2}=.18\right)$, after controlling for prior interest $\left(\eta^{2}=.13\right)$. In the context of mathematics, Linnenbrink-Garcia et al. (2010) proved situational interest to predict individual interest $(\beta=.24)$ among students of grades 7 through 12 after controlling for the initial individual interest rate $(\beta=.45)$.

Besides these three studies, there is little empirical evidence to support the relationship between situational and individual interest, because few studies consider both types of interest.

\subsubsection{Sources of Situational Interest}

Different branches of interest research have examined conditions to promote situational interest. These will be outlined in the following paragraphs.

\section{Instructional Conditions to Enhance Situational Interest}

Features of learning materials and instructional parameters may serve as triggers for situational interest. Such classroom parameters that stimulate situational interest have mostly been studied in the domain of reading (e.g., Guthrie et al., 2006; Schiefele, 2009) and mathematics. Mitchell (1993) identified elements that trigger ('catch') and maintain ('hold') situational interest in the mathematics classroom. Catch elements are used to generate learner attention and focus concentration on the lesson's content. Attention and concentration are indicators of triggered situational interest (e.g., Chen, 1999; Hidi, 1990). In contrast, hold elements are more directly related to the content of the lesson and refer more strongly to individual values. This classification of catch and hold elements matches models of interest development (e.g., Hidi \& Renninger, 2006; Krapp, 2002) stressing the value-related component of interest to be more pronounced in later phases of interest development. Mitchell found cognitive stimuli (puzzles and computers) and social stimuli (group work) as catch facets. Active involvement and the perception of content as personally meaningful were effective hold-facets. 
In the domains of psychology and the arts (Silvia, 2010), and in computer-based learning in mathematics (Durik \& Harackiewicz, 2007; Magner, Schwonke, Aleven, Popescu, \& Renkl, 2014), visual stimuli have been applied as catch facets for situational interest. Qualitative (Dohn, 2011, 2013) and quantitative research (Chen, 1999) suggest novelty to be a source of situational interest in various interest domains.

Concerning active involvement, there is evidence that hands-on experiences in (extracurricular) science education encourage situational interest (Dohn, 2011; Hummel, Glück, Jürgens, Weisshaar, \& Randler, 2012). Applying qualitative methods, Palmer (2009) found hands-on activities, meaningfulness, and group work to be sources of situational interest in the science classroom across ninth grade students. Hulleman, Godes, Hendricks, and Harackiewicz (2010) manipulated the perceived meaningfulness of a new math technique. Writing an essay, participants in the treatment condition were asked to describe how the information of the technique was relevant to their lives; control group members did not engage in such a reflection. An effect of the treatment on situational interest $(\beta=.24)$ was found. However, the mentioned studies did not differentiate between catch and hold facets in terms of Mitchell's (1993) differentiation.

\section{Need-Related Evaluation of the Learning Environment}

Expanding the person-object-theory of interest, Krapp (2002) suggested that fulfillment of the basic needs, according to self-determination-theory (Ryan \& Deci, 2000), drives interest and its development. Need for competence refers to the desire to be efficacious and to reach goals. Need for autonomy describes the motive to be selfinitiating and self-regulating. Social relatedness involves feelings of social security and being connected with others. Studies show that the needs are intercorrelated (e.g., Kunter, Baumert, \& Köller, 2007).

There is empirical evidence that basic need fulfillment influences situational interest; the relative importance of the three needs seems to depend on the context of investigation (e.g., Neubauer, Geyer, \& Lewalter, 2014). Based on structural equation modeling, Minnaert, Boekaerts, and Brabander (2007) found the subjective fulfillment of all basic needs to influence situational interest during project-based vocational education among secondary students. The importance of social relatedness was accentuated, as it was the strongest predictor of situational interest (mean $r=.32$ ) among the three needs in four out of five measurement points. This may be due to the instructional setting that included cooperative learning. In contrast, studies in the context of vocational education and mathematics have suggested that relatedness is of lesser importance than the two other needs (Krapp, 2005; Kunter et al., 2007). A recent study on garden-based education (Skinner \& Chi, 2012) has suggested that autonomy $(r=.56)$ is more strongly associated with situational engagement in gardening than 
relatedness $(r=.43)$ or competence $(r=.36)$. This may result from the intervention putting an emphasis on students' autonomy by involving them in planning activities ${ }^{21}$.

Research on the relationship between need fulfillment and interest hardly distinguished whether the needs are effective in the process of triggering or maintaining situational interest. However, connections between both research branches can be established. Perceived social relatedness fulfillment is likely to operate particularly in the triggering process, because Mitchell's (1993) catch element "group work" supports social interaction. Individuals might not need as much social comfort to get into a learning situation concerning a topic in which they are already interested. In contrast, for individuals with little prior interest, the feeling of social belonging may function as a kind of "opener" to the learning situation and facilitate their disposition to become interested. In this respect, Minnaert et al. (2007) found that social relatedness was most strongly related to situational interest in the beginning phase of work on a project $(r=.48)$ compared to four later time points during this work (mean $r=.28$ ).

On the other hand, active involvement-a hold element, according to Mitchell (1993) — can be assumed to address feelings of one's own competence (Lewalter \& Geyer, 2009). This may specifically apply to practical learning contexts such as school farms that result in immediately visible and tangible outcomes. Such practical outcomes may support competence fulfillment. On this note, competence fulfillment is likely to be specifically beneficial in the process of maintaining interest.

\section{Prior Individual Interest as a Facilitator for Situational Interest}

The mentioned models of interest development (Hidi \& Renninger, 2006; Krapp, 2002) explain the development from situational to individual interest. However, there is evidence for a reciprocal influence between situational and individual interest. As shown, an existing individual interest also positively relates to situational interest (see Figure 9.1). Studies applying regression analyses proved prior individual interest to be a predictor of later situational interest in the mathematics classroom ( $\beta=.30-.51$; Durik \& Harackiewicz, 2007; Hulleman et al., 2010; Tsai et al., 2008) and in psychology courses ( $\beta=.40$, Harackiewicz et al., 2008). Tsai et al. (2008) achieved similar results for two language-related subjects. Correlations were found between the prior individual interest in botany and situational interest in a botanical treatment $(r=.46)$, as well as between the prior individual interest in zoology and situational interest in a zoological treatment ( $r=.69$; Hummel, Glück, Jürgens, Weisshaar, \& Randler, 2012) in students of grades 4 through 6 . These mentioned findings suggest that research on interest

${ }^{21}$ Note that the reported studies rely on correlations. Strictly speaking, the claim that one need is more important for situational interest than the others is not valid due to the lack of inferential statistics or confidence intervals. 
development should consider the influence of an existing individual interest on (later) states of situational interest.

\subsubsection{A Model of Interest Development}

The mentioned models, theories, and empirical findings concerning the development of individual interest, conditions to trigger and maintain situational interest, and the interplay of situational interest and individual interest have mostly been analyzed separately in previous studies. Combining these findings, we postulate a model of interest development applicable to learning contexts with two consecutive interventions including a combination of extracurricular and in-school learning (Figure 9.2).

The model incorporates two consecutive interventions because frequency and duration of interventions determine the development of individual interest through repeated occurrences of situational interest (Hidi \& Renninger, 2006). Besides, prior studies indicate that individual interest is not easy to change and that it declines in the medium term (four weeks after the intervention) if only a single intervention is applied (e.g., Holstermann et al., 2012). Hands-on extracurricular treatments have been found to potentially increase interest. This is particularly true if the experiences are integrated into subsequent classroom activities (e.g., Dillon et al., 2006). For this reason, the proposed model considers a first extracurricular intervention as the "main" intervention followed by a second intervention in school to reinforce the effect of the first one. The first intervention is intended to increase individual interest, whereas the second intervention is thought to maintain the increased level of interest. For this reason, the first intervention is supposed to be of a longer duration than the second one. A followup assessment is provided five weeks after the second intervention in order to consider medium-term effects.

The model incorporates reciprocal interrelations of situational interest and individual interest. These are deemed crucial in the process of interest development (e.g., Harackiewicz et al., 2008; Linnenbrink-Garcia et al., 2010), and direct paths from prior to later states of individual interest (situational interest) are included in the model (cf. Randler \& Bogner, 2007). Moreover, conditions that evoke and promote situational interest are integrated. Competence, autonomy, and social relatedness are applied as sources of situational interest in the first intervention because they are directly linked to the experiences of an extended extracurricular intervention (e.g., Skinner \& Chi, 2012). Interaction effects of the prior individual interest and need fulfillment are possible. Compensatory interaction would indicate the respective need fulfillment to be particularly effective for situational interest concerning participants with little prior individual interest (as a kind of 'catch'). In such a case, the interaction coefficient becomes negative. A negative coefficient can be assumed for social relatedness due to its similarity with Mitchell's (1993) catch element, group work. In contrast, a synergistic interaction (marked by a positive coefficient) would indicate that the need fulfillment is 
especially effective for participants with comparatively high prior individual interest. Such a synergistic interaction can be understood as a hold element because situational interest is specifically addressed if prior individual interest was high. This hypothetically applies to subjective competence fulfillment that links to Mitchell's (1993) hold element active involvement.

Instructional catch and hold elements can be designed and directly influenced by teachers (Mitchell, 1993). Therefore, they can be incorporated as sources of situational interest within the second intervention in school. Interactions between the catch and hold elements and prior situational interest are considered.

Moreover, we suppose that initial individual interest facilitates the fulfillment of autonomy, competence, and social relatedness during the first intervention (cf. Renninger \& Hidi, 2011). Participants with initially higher interest are more likely to have knowledge and to be aware of their own knowledge gaps (Dochy et al., 1999). They will use the farm stay to accumulate competence and thereafter perceive more competence fulfillment than individuals with low prior interest. A similar argumentation holds for the other needs (e.g., participants with a preexisting interest engage more in communicating with the farm staff or help peers and thus establish better social relationships).

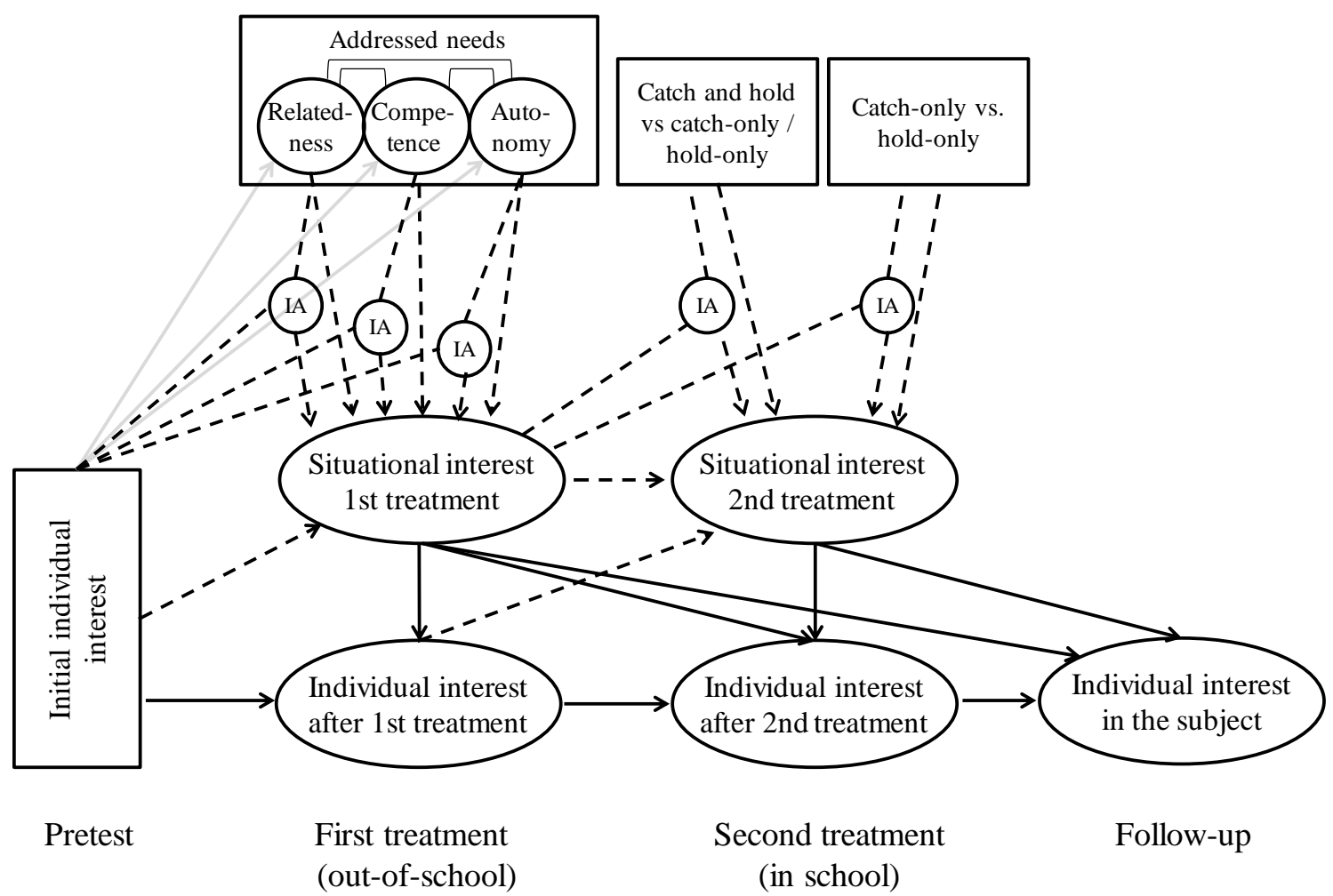

Figure 9.2: Postulated model of situational interest and individual interest development for learning contexts with extracurricular and in-school interventions ( $I A=$ interaction, solid black arrows = paths to individual interest, dashed arrows = paths to situational interest, solid grey arrows = additional paths) 


\subsubsection{The Present Study}

Referring to the person-object approach (e.g., Krapp, 2002), the subject area of agriculture was selected as interest object in our study because of its importance for education for sustainable development. The postulated model was tested in the context of agricultural learning - a subject area that has hardly been considered in interest research. An extracurricular school farm program that engaged the participants in typical agriculture-related activities (see paragraph 9.3.3) was selected as the "main" intervention with a comparatively long duration (five days), in contrast to many other farm education conceptions that rarely exceed a one-day visit. The second intervention was a curricular-valid learning unit in school that referred to the farm experiences. It was carried out in three variants: catch-only, hold-only, and a combination of catch and hold elements (e.g., drawing on Mitchell, 1993; for details of the learning unit and the three variants see 9.3.4). In compliance with theory (e.g., Mitchell, 1993; Silvia, 2010) social, visual, and cognitive stimuli were applied as catch elements. Learners' active involvement and addressing their sense of personal meaningfulness were used as hold elements.

Hypothesis 1: We expected the school farm program to arouse situational interest, which was supposed to increase individual interest in the short-term (immediately after the intervention). The increase in individual interest after a school farm stay was already demonstrated in a larger data pool that utilized a control group design (Bickel, Strack, \& Bögeholz, resubmitted) $)^{22}$. Expanding upon this finding, we further hypothesized that the learning unit conducted three weeks after the school farm stay would maintain the increased level of individual interest (hypothesis 1a). A slight decrease in individual interest was considered likely in the medium-term as assessed five weeks after the second intervention (cf. Holstermann et al., 2012; hypothesis 1b).

Hypothesis 2: The experience of autonomy support, competence, and social relatedness during a school farm stay involving hands-on work experiences enhances situational interest in working on the farm (hypothesis 2a). Concerning the second intervention, we postulated a combined intervention with catch- and hold-facets to be superior in evoking situational interest compared to variants with either catch or hold elements, only (hypothesis $2 b$ ). Moreover, we investigated whether one of the catchand hold-only variants better activates situational interest than the other.

Hypothesis 3: Finally, we aimed to advance the understanding of the relationship between situational interest and individual interest. We assumed that prior states of individual interest add to predict situational interest (hypothesis $3 a$ ) and that situational

\footnotetext{
22 The data in the present study derive from the same data pool.
} 
interest concerning both interventions fosters individual interest immediately after the intervention and at later states (hypothesis $3 b$ ).

\subsection{Methods}

\subsubsection{Participants}

Participants were fifth and sixth grade students of nine school classes coming from five different German federal states $\left(M_{\text {age }}=10.80, S D=.79\right)$. Four school classes were recruited from university-track high schools (Gymnasium), and five classes came from secondary schools ending after grade nine or ten, respectively (Haupt- and Realschule). All data were collected by means of paper-pencil tests. Students who participated in all four measurements and provided sufficient answers were included in the analysis ( $N=209,105$ girls, 104 boys).

\subsubsection{Procedure}

We investigated participants' individual interest in agriculture at four points in time over a period of approximately ten weeks. The first questionnaire (T0) was filled out at school as a baseline measure approximately two weeks before the planned school farm stay (first intervention). Immediately after the first intervention on the school farm, the second questionnaire was administered (T1). Besides individual interest, the T1questionnaire asked for participants' situational interest in working on the school farm and their perceived fulfillment of autonomy, competence, and social relatedness during the farm work. Three weeks later, a learning unit was administered in school by the respective teachers as the second intervention. Before the lessons, teachers received comprehensive oral and written instructions and were given the opportunity to clarify their understanding of the implementation. The learning unit spanned four lessons and was followed by the third investigation (T2). Students indicated their individual interest in agriculture and their situational interest in the learning unit. A follow-up measure was conducted five weeks after the second intervention (T3) comprising a measure of individual interest in agriculture, only.

\subsubsection{Residential School Farm Intervention}

Five school farms collaborated in our research. The intervention was comprised of the regular programs of the farms over five days. We assumed that the school farm intervention was likely to promote situational interest, because it incorporated many of the mentioned catch and hold elements (indicated by the parenthesized adjuncts in the following paragraph) and addresses the needs for autonomy, competence, and social relatedness.

The participating students worked in small groups under the instruction of the farm staff. The groups consisted of approximately five members (group work as social stimulus to trigger situational interest). The tasks comprise typical jobs related to 
animal husbandry (e.g., milking, feeding), gardening (e.g., sowing, weeding, harvesting), and primary food processing (e.g., baking, preserving, milk processing). Because of the novelty of the school farm activities for most participants, the activities represented a cognitive stimulus relating to the triggering phase of situational interest. School farms actively involve participants and provide tasks that are tailored to the abilities of the participants (active involvement, hands-on, addressing maintained situational interest). The perceived personal meaningfulness of the tasks-another element to maintain situational interest-is supported, because food production, an overarching topic of the school farm, is directly related to the participants' daily lives. The school farm intervention is likely to address both phases of situational interest and thus to foster the development of individual interest (cf. Hidi \& Renninger, 2006).

Considering autonomy, the supervisors facilitate self-regulated learning by providing the information needed to successfully complete the given tasks. The actual accomplishment of the tasks, however, is left to the learners. In addition, some routine jobs have to be carried out several times a week, which allows for a higher degree of self-initiated learning and autonomous action (e.g., a group of participants may be allowed to feed animals autonomously after having done this job adequately before. Working in small groups facilitates social interaction and enables social relatedness among the participants and between participants and supervisors. Additionally, it allows all group members take an active part, which is a core idea of school farms. The need for competence is addressed by thoroughly prepared and feasible working units. The participants' sense of personal effectiveness is further supported by immediately visible results. Altogether, the school farm stay is an adequate extracurricular intervention to meet the needs for competence, autonomy, and social relatedness.

\subsubsection{Learning Unit in School}

The second intervention was developed by the researchers and included two sequenced double periods (90 minutes each). For both double periods, instructional catch and hold elements had been developed and tested in a pilot study realizing three variants of the learning unit (with catch-only, hold-only, and combined catch and hold elements). Applying observations of implementation and teacher interviews, the pilot study served to optimize the learning unit regarding suitability of the catch and hold elements and other instructional factors (i.e., time structure, methodological approaches, information density, and reference to educational standards; Duisen, 2012). Complying with existing research (cf. section 9.2.3), we included social, cognitive, and visual stimuli as catch elements and active involvement as well as personal meaningfulness as hold elements. Multiple kinds of stimuli were considered, because triggering and maintaining situational interest through different channels enhances the likelihood of adequately addressing as many students as possible. 
The content of the lessons complied with the National Educational Standards for biology (KMK, 2004). Regarding the farm experiences, the first double period contained a comparison of different housing systems for laying hens under consideration of characteristic behavior patterns, labor input, costs, and egg selling prices. In the second double period, students learned about the functional parts of the potato plant and the potato tuber, the diversity of potato varieties, the potato cropping process, and the use of potatoes in the foods and commodities of daily life. The primary educational objectives of the learning unit were to address socioscientific decision-making and conceptual knowledge.

Catch and hold elements were applied to specifically foster the process of, respectively, triggering and maintaining situational interest according to theory (Hidi \& Renninger, 2006; Mitchell, 1993). Prior experiences with the object of interest, as well as the degree of existing individual interest, are suggested to influence the individual reaction to an interest-evoking element or instructional setting (Durik \& Harackiewicz, 2007; Hidi, 1990).

In both double periods, the catch conditions (catch-only, catch and hold) applied group work as a social stimulus. The instructional materials in both catch conditions contained additional pictures as visual stimuli. Concerning cognitive stimulation, the lessons on laying hens involved a film sequence in the catch conditions. The same information contained in the film was conveyed by text material in the condition of the learning unit without catch elements (hold-only). The double period on potatoes was framed as a quiz in both catch conditions to add a cognitive stimulus (Table 9.1).

Regarding the hold elements, students' active involvement should be aroused by hands-on activities in both double periods. For example, students in the hold conditions (hold-only as well as catch and hold) explored the differences between several potato varieties (e.g., potato skin, eyes, shapes, and pulp) by working with real potato tubers and the required tools (e.g., magnifiers, and knives). Instead, participants of the catchonly condition obtained pictures of the potato varieties and thus did not work with the real object in a hands-on way.

Meaningfulness was manipulated by content references to students' daily lives (e.g., how to recognize eggs from different housing systems in retail shops). Moreover, students in the hold conditions were directly addressed both orally and in written teaching materials throughout both double periods (e.g., in a task description: "Y You have decided to keep laying hen" instead of using a fictive person), so that they might become more involved and identify with the acting person in the task. This hold element particularly unfolds its impact in combination with the content references to daily life that are included in both double periods (see Table 9.1). This hold element is not included in Table 9.1, because it was repeatedly applied throughout the entire learning unit. 
To trigger situational interest, the catch elements were mainly included in the introductory and working phases of the double periods. In compliance with the temporal distinction between triggered and maintained situational interest (e.g., Hidi \& Renninger, 2006), the hold elements were integrated subsequently during the working phase and during the terminal phase of both double periods (cf. Table 9.1).

Table 9.1 summarizes the operationalized catch and hold elements and illustrates how they refer to catch and hold facets according to theory (see Table 9.1 "mode of action").

Table 9.1: Schedule and operationalization of 'catch' and 'hold' elements in both double periods of the second intervention in school (multiple catch and/or hold elements within one phase are listed sequentially)

$1^{\text {st }}$ Double period on laying hens

\section{Catch (C) and Hold (H) elements}

\section{Sequence}

1 Introduction

2. Working phase 1

3. Verification of results phase 1

4. Working phase 2

\section{Operationalization}

pictures in teaching materials

film sequence (C)

pictures in teaching materials (C)

group work (C)

content references to daily life $(\mathbf{H})$

hands-on task $\mathbf{( H )}$

5.Presentation, verification of results

content references
Mode of action

visual stimulus ${ }^{2}$

cognitive stimulus ${ }^{1}$

visual stimulus ${ }^{2}$ social stimulus ${ }^{1}$ meaningfulness ${ }^{1}$ active involvement ${ }^{1}$ meaningfulness ${ }^{1}$ phase 2

$2^{\text {nd }}$ Double period on potatoes

\begin{tabular}{|c|c|c|}
\hline \multirow[b]{2}{*}{ Sequence } & \multicolumn{2}{|c|}{ Catch $(\mathrm{C})$ and Hold $(\mathrm{H})$ elements } \\
\hline & Operationalization & Mode of action \\
\hline 1. Introduction & framing the lesson as a quiz (C) & cognitive stimulus $^{1}$ \\
\hline 2. Working phase & $\begin{array}{l}\text { group work }(\mathbf{C}) \\
\text { pictures in teaching materials }(\mathbf{C}) \\
\text { hands-on task }(\mathbf{H}) \\
\text { content references to daily life } \mathbf{( H )}\end{array}$ & $\begin{array}{l}\text { social stimulus }^{1} \\
\text { visual stimulus }^{2} \\
\text { active involvement }^{1} \\
\text { meaningfulness }^{1}\end{array}$ \\
\hline 3. Verification of results & content references to daily life $\mathbf{( H )}$ & meaningfulness ${ }^{1}$ \\
\hline
\end{tabular}

The learning unit was applied in three variants. Of the 20 school classes that we contacted, we intended 12 to take part so that four school classes would have been in each condition of the second treatment. Ultimately, nine school classes took part in our research. A catch-only, a hold-only, and a combined catch and hold variant were administered in three school classes each $\left(n_{\text {Catch }}=72, n_{\text {Hold }}=67, n_{\text {Catch }+ \text { Hold }}=70\right)^{23}$. It

\footnotetext{
${ }^{23}$ Under test theoretical considerations, a fourth variant as control group without additional catch and hold elements should have been applied. However, we had to convince teachers to take part in this study, which meant a lot of work for them due to the four measurement points. Thus, we had to encourage them by providing attractive and interest-conveying instructional materials.
} 
must be noted, that it is impossible to implement a lesson free of any 'catch' (or 'hold') at all, disregarding the manipulated catch and hold elements. In this regard, the variants specifically addressed the triggering process, the maintaining process, or both processes of situational interest. To allocate the school classes to the three variants, we attempted to parallelize the visited school farm, the school track, and the grade of school. Because of the continuous data collection and cancelations of several school classes during this process, we could not fully implement the planned distribution (see Appendix A).

In sum, the three variants operationalized the approach of the model postulating an impact of combined catch and hold elements for situational interest. Moreover, the variants allow investigating the effect of emphasizing only catch or hold elements.

\subsubsection{Measures}

\section{Individual Interest}

Individual interest in agriculture was assessed as the mean score of a 20-item instrument applied in a factorial design combining four structural components of individual interest with five agricultural content areas (i.e., animal husbandry, arable farming, vegetable and fruit cropping, primary food processing, and agricultural engineering). The interest components derived from an existing individual interest scale that had been developed and applied in several studies (e.g., Schiefele, 1996; Schiefele \& Krapp, 1996). They refer to feeling-related and value-related valences of interest (cf. section 1.1). Worded as bipolar adjective pairs, the four components were interested vs. boring, stimulated vs. impassive, attentive vs. inattentive, and meaningful vs. unimportant. The four interest components were each put in relation to the five agricultural content areas (e.g., "For me, [arable farming] is unimportant (1) / meaningful (4)"). Explorative and confirmatory factor analyses proved the validity of the instrument (for further details, see Bickel \& Bögeholz, 2013b, Bickel, Strack, \& Bögeholz, 2014). In the present study, Cronbach's alpha for the individual interest in agriculture ranged, for the four measurements, between .89 and .90 .

To limit students from directly relating their individual interest ratings to their experiences in the intervention that just passed, the questionnaire contained a boldtyped text box at both measurements that also included situational interest (T1, T2), stating: "The following part is about your interest in different agricultural content areas and not about working on the school farm (the school lessons)."

\section{Situational Interest}

An existing scale on students' situational interest (Chen, 1999) was modified by adapting the items to the content of this investigation. The scale was tested in a previous study by means of an exploratory factor analysis that identified eight central items (Bickel \& Bögeholz, 2013b). Due to the fluid character of situational interest and 
in order to be clearly differentiated from the individual interest measure, the items were related to the given experience, i.e., working on the school farm (T1) and the learning unit in school (T2), respectively. The items contained characteristics of situational interest such as focused attention, enjoyment, and exploration intention (cf. Schiefele, 2009; Chen, 1999; e.g., "I want to explore everything on the school farm"). The applied scale ranged from 1 (not true) to 5 (true). Cronbach's alpha for the situational interest was .91 at $\mathrm{T} 1$ and .90 at $\mathrm{T} 2$.

\section{Autonomy, Competence, Social Relatedness}

To assess the perception of the basic needs, three four-item scales ranging from 1 (not true) to 5 (true) were applied. The scale that addressed perceived autonomy support (autonomy, $\alpha=.69$ ) was adapted from the Learning Climate Questionnaire (Black \& Deci, 2000). An exemplary item was: "The farmers encourage me to ask questions."

Competence fulfillment (competence, $\alpha=.72$ ) comprised two items that were taken from the Basic Psychological Needs Scale (BPNS; Baard, Deci, \& Ryan, 2004), and one item each from the Perceived Competence Scale (Williams, Freedman, \& Deci, 1998) and from the Intrinsic Motivation Inventory (Deci, Eghrari, Patrick, \& Leone, 1994). For example, students rated the item: "While working on the school farm, I have been able to learn new skills."

The scale on perceived social relatedness (relatedness, $\alpha=.82$ ) was selected from the BPNS (Baard et al., 2004). An example item was: "While working on the school farm, I get along with my classmates."

All items were adapted to the agricultural context of this study. The intercorrelations of the addressed needs were $r=.57$ for autonomy and competence, $r=.34$ for autonomy and relatedness, and $r=.47$ for competence and relatedness.

\section{Effect Codes for Catch and Hold Elements}

To test whether the combined catch and hold variant of the in-school learning unit was superior to the variants with a single facet, an effect code was applied (catch and hold). The combined catch and hold variant scored 1 and the variants with a single facet scored -1 . To compare the effect of the variants with a single facet on situational interest with each other, a second almost orthogonal effect code (catch or hold) scored 1 in the hold-only variant, -1 in the catch-only variant, and 0 in the catch and hold variant.

\subsection{Results}

\subsubsection{Individual Interest Development}

Table 9.2 presents descriptive statistics for the all variables that were used in later analyses. To analyze the development of individual interest between T0 and T3, a repeated measures analysis of variance was applied with a priori contrasts. Results proved a significant change in participants' individual interest ratings over time $(F(3$, 
205) $\left.=10.76, p<.001, \eta^{2}=.05\right)$. The initial interest increased from T0 to T1 after the school farm stay $\left(F(1,205)=10.15, p=.002, \eta^{2}=.05\right.$ and was maintained between T1 and T2 after the second intervention in school $\left(F(1,205)=1.58, p=.21, \eta^{2}<.01\right)$. Between T2 and T3, however, interest declined to the initial level $(F(1,205)=21.20, p$ $\left.<.001, \eta^{2}=.09\right)$.

Table 9.2: Means, standard deviations, and zero-order correlations of all measured variables

\begin{tabular}{|c|c|c|c|c|c|c|c|c|c|c|c|}
\hline Variable & 1 & 2 & 3 & 4 & 5 & 6 & 7 & 8 & 9 & 10 & 11 \\
\hline $\mathrm{M}$ & 3.09 & 3.18 & 3.15 & 3.03 & 4.05 & 3.71 & 4.25 & 4.41 & 4.25 & -.33 & -.02 \\
\hline $\mathrm{SD}$ & .51 & .48 & .51 & .55 & .84 & .90 & .71 & .60 & .78 & .95 & .82 \\
\hline 1. II_T0 & - & & & & & & & & & & \\
\hline 2. II_T1 & $.67^{* * * *}$ & - & & & & & & & & & \\
\hline 3. II_T2 & $.67^{* * * *}$ & $.77^{* * * *}$ & - & & & & & & & & \\
\hline 4. II_T3 & $.60^{* * * *}$ & $.67^{* * * *}$ & $.76^{* * *}$ & - & & & & & & & \\
\hline 5. SI_T1 & $.43^{* * * *}$ & $.59^{* * * *}$ & $.54^{* * * *}$ & $.53^{* * * *}$ & - & & & & & & \\
\hline 6. SI_T2 & $.39^{* * * *}$ & $.43^{* * *}$ & $.49^{* * * *}$ & $.48^{* * * *}$ & $.50^{* * * *}$ & - & & & & & \\
\hline 7. Autonomy & $30^{* * * *}$ & $.42^{* * *}$ & $.36^{* * *}$ & $.25^{* * *}$ & $.49^{* * * *}$ & $.34^{* * * *}$ & - & & & & \\
\hline 8. Competence & $.32^{* * * *}$ & $.46^{* * *}$ & $.31^{* * * *}$ & $.34^{* * *}$ & $.65^{\text {**** }}$ & $.35^{\text {**** }}$ & $.57^{* * *}$ & - & & & \\
\hline 9. Relatedness & .13 & $.21^{* *}$ & $.20^{* * *}$ & $.16^{* * * *}$ & $41^{* * * *}$ & $21^{* * * *}$ & $.34^{* * *}$ & $.47^{* * * *}$ & - & & \\
\hline 10. Catch \& hold & .10 & $.15^{*}$ & $.17^{*}$ & $.13^{*}$ & $.20^{* *}$ & $.23^{* *}$ & .09 & -.01 & .02 & - & \\
\hline 11. Catch or hold & -.03 & $.21^{* * *}$ & -.09 & -.06 & -.03 & -.04 & -.10 & -.09 & -.11 & .02 & \\
\hline
\end{tabular}
$\mathrm{II}$ = individual interest, $\mathrm{SI}=$ situational interest, T0, T1, T2, T3 = Measurement points. Individual interest ratings range from 1 to 4 , situational interest and need-related variables range from 1-5, Catch \& hold and Catch or hold range from -1 to $1 . " p<.05,{ }^{* *} p<.01,{ }^{* * *} p<.001$

\subsubsection{Catch and Hold Effects on Situational Interest in the Learning Unit}

According to hypothesis $2 \mathrm{~b}$, a one-way ANOVA proved significant differences in situational interest at T2 between the three variants-catch-only, hold-only, and combined catch and hold $\left(F(2,206)=6.06, p=.003, \eta^{2}=.06\right)$. Applying a priori contrasts, it was found that the combined catch and hold treatment evoked a higher situational interest than both single element groups $(p=.001, d=.24)$. Conversely, the hold-only and catch-only treatments did not differ $(p=.463, d=.05)$. This is illustrated in Figure 9.3.

Further one-way ANOVAs were conducted with individual interest at T2 and T3 as dependent variable to rule out the possibility that the treatment had a stronger effect on individual interest compared to situational interest (which would have been a violation to our proposed model). Compared to situational interest at T2, the treatment had a smaller effect on individual interest at T2 $\left(F(2,206)=4.02, p<.05, \eta^{2}=.04\right)$ and no effects on individual interest at T3 $\left(F(2,206)=2.15, p>.05, \eta^{2}=.02\right)$. Thus, our assumptions were not invalidated. 


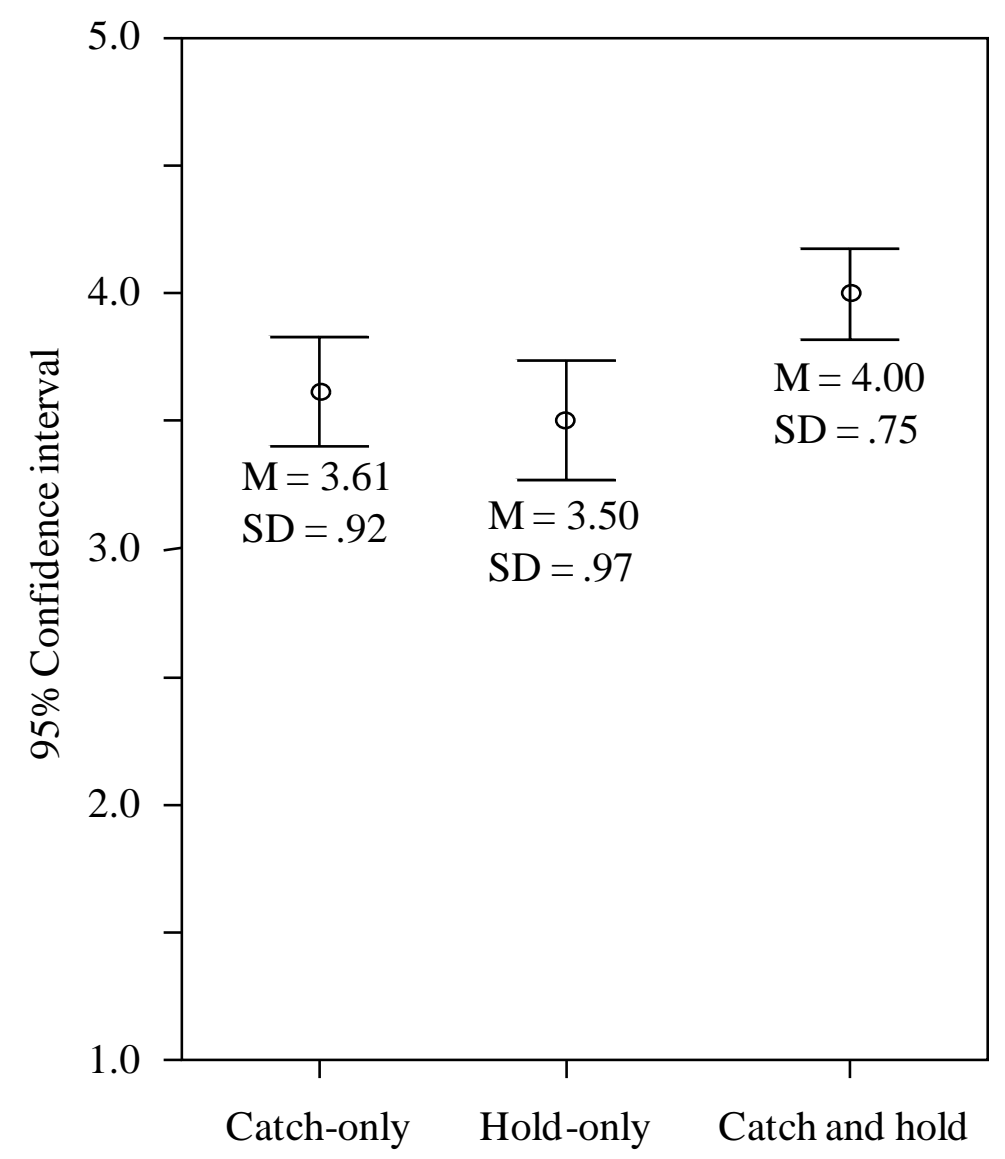

Figure 9.3: Situational interest in the learning unit in school (T2) as effected by the variants with catch-only, hold-only, and combined catch and hold elements

\subsubsection{Path Model on Situational and Individual Interest Development, Determinants, and Interrelations}

A path model was built to analyze the sources of situational interest at both measurement points (hypotheses $2 \mathrm{a}$ and $2 \mathrm{~b}$ ) and the interrelationship of situational interest and individual interest (hypotheses $3 a$ and $3 b$ ).

Prior to the path analysis, hierarchical regression analyses were conducted with each measure of situational interest taken as a dependent variable to identify possible interaction effects that would be relevant for the path model. Two-way interaction effects of predictor pairs were tested following the procedure put forth by Aiken and West (1993). In both analyses, step one controlled for prior rates of individual interest (and situational interest in case of the second intervention). Regarding situational interest in working on the school farm as a dependent variable, we tested for interaction between the initial individual interest and perceptions of autonomy, competence, and social relatedness fulfillment. Table 9.3 shows that a compensatory interaction of initial individual interest and perceived social relatedness added to predict situational interest at $\mathrm{T} 1$. The interaction effect indicated that only participants in the 
lower part of the individual interest distribution at T0 increased their situational interest if they felt socially embedded.

Concerning situational interest in the learning unit, none of the tested interactions of prior situational interest and the catch and hold elements (catch and hold, catch or hold) qualified. Moreover, results revealed that "catch and hold" had a main effect on situational interest, whereas "catch or hold" did not predict situational interest.

Table 9.3: Hierarchical regression analyses of situational interest ratings during the school farm stay (T1) and during the learning unit in school (T2)

\begin{tabular}{llcc}
\hline Dependent variable & Predictor & $\Delta \mathbf{R}^{\mathbf{2}}$ & Beta \\
\hline & Step 1 (enter): & $.188^{* * *}$ & $.244^{* * *}$ \\
& II_T0 & & \\
Step 2 (enter): & $.332^{* * * *}$ & $.413^{* * *}$ \\
Situational interest in & Competence & & $.146^{*}$ \\
working on the & Autonomy & & $.113^{*}$ \\
school farm (SI_T1) & Relatedness & & $-.166^{* *}$ \\
& IA_II_T0_Related & & .121 \\
& IA_II_T0_Autonomy & & .015 \\
\hline & IA_II_T0_Competence & $.275^{* * *}$ & $.344^{* * *}$ \\
& Step 1 (enter): & & $.186^{*}$ \\
Situational interest in & SI_T1 & & \\
the learning unit in & Step 2 (enter): & $.028^{(*)}$ & $.146^{*}$ \\
school (SI_T2) & Catch\&Hold & & -.008 \\
& Catch|Hold & & -.075 \\
& IA_SI_T1_Catch\&Hold & & -.083 \\
\hline
\end{tabular}

$\mathrm{II}=$ individual interest, $\mathrm{SI}=$ situational interest, $\mathrm{IA}=$ interaction, $\mathrm{T} 0, \mathrm{~T} 1=$ Measurement points ${ }^{(*)} \mathrm{p}<.10,{ }^{*} p<.05,{ }^{* *} \mathrm{p}<.01,{ }^{* * *} p<.001$

Based on the regression results, we modified our postulated model by eliminating all interactions but that of individual interest at T0 with social relatedness on situational interest at T1 and by eliminating the path from "catch or hold" to situational interest at T2. Apart from these configurations, the model was applied as described in Figure 9.2.

The path analysis was conducted on the correlation matrix (see table 9.2) of all integrated variables using Lisrel 8.80 (Jöreskog \& Sörbom, 1996). As fit indices the adjusted goodness-of-fit index (AGFI; target value: > 0.8; Sharma, 1996), the parsimony goodness-of-fit index (PGFI), and the root mean square error of approximation (RMSEA; target value: < 0.08; Browne \& Cudeck, 1993) are reported. 
To consider the intercorrelations of autonomy, competence, and social relatedness (Kunter et al., 2007), the residuals of these variables were allowed to correlate.

The model was supported and achieved reasonable global fit indices ( $d f=28$, $\mathrm{AGFI}=.886, \mathrm{PGFI}=.404, \mathrm{RMSEA}=.072$; see Figure 9.4. In line with hypothesis $2 \mathrm{a}$, autonomy, competence, social relatedness, and the interaction of relatedness with initial individual interest had an effect on situational interest at T1. Subjective fulfillment of the need for competence had a stronger effect $(.41$, with $\mathrm{Cl} .28-.54)$ on situational interest compared to the other needs and even compared to prior individual interest. Also hypothesis $2 \mathrm{~b}$ was supported because "catch and hold" was related to situational interest during the learning unit in school. This means that the variant of the learning unit with catch and hold elements was superior to the variants with only catch or only hold elements in generating situational interest.

In agreement with hypothesis $3 \mathrm{a}$, prior rates of individual interest were related to situational interest at both measures with almost equally small effect sizes (.23 for situational interest at T1 and .20 for situational interest at T2). Also, the hypothesized effects of situational interest on individual interest immediately after the respective intervention and on later states of individual interest were approved (hypothesis $3 \mathrm{~b}$ ). The strongest influence was found for situational interest at T1 on individual interest at $\mathrm{T} 1$ with a medium effect size $(.37$, with $\mathrm{Cl} .27$ - .47). The impact of situational interest in the learning unit on individual interest at T2 was smaller (.15). The effect of situational interest at T1 on individual interest at T2 is negligible and is probably overshadowed by situational interest at T2. But both measures of situational interest added to individual interest at T3 (see Figure 9.4).

Prior states of individual interest were highly related to later states $(\approx .50)$. The initial individual interest was of particular importance for all subsequent states of individual interest and-to a lesser extent-for the perceived fulfillment of autonomy, competence, and social relatedness needs during the farm works. 


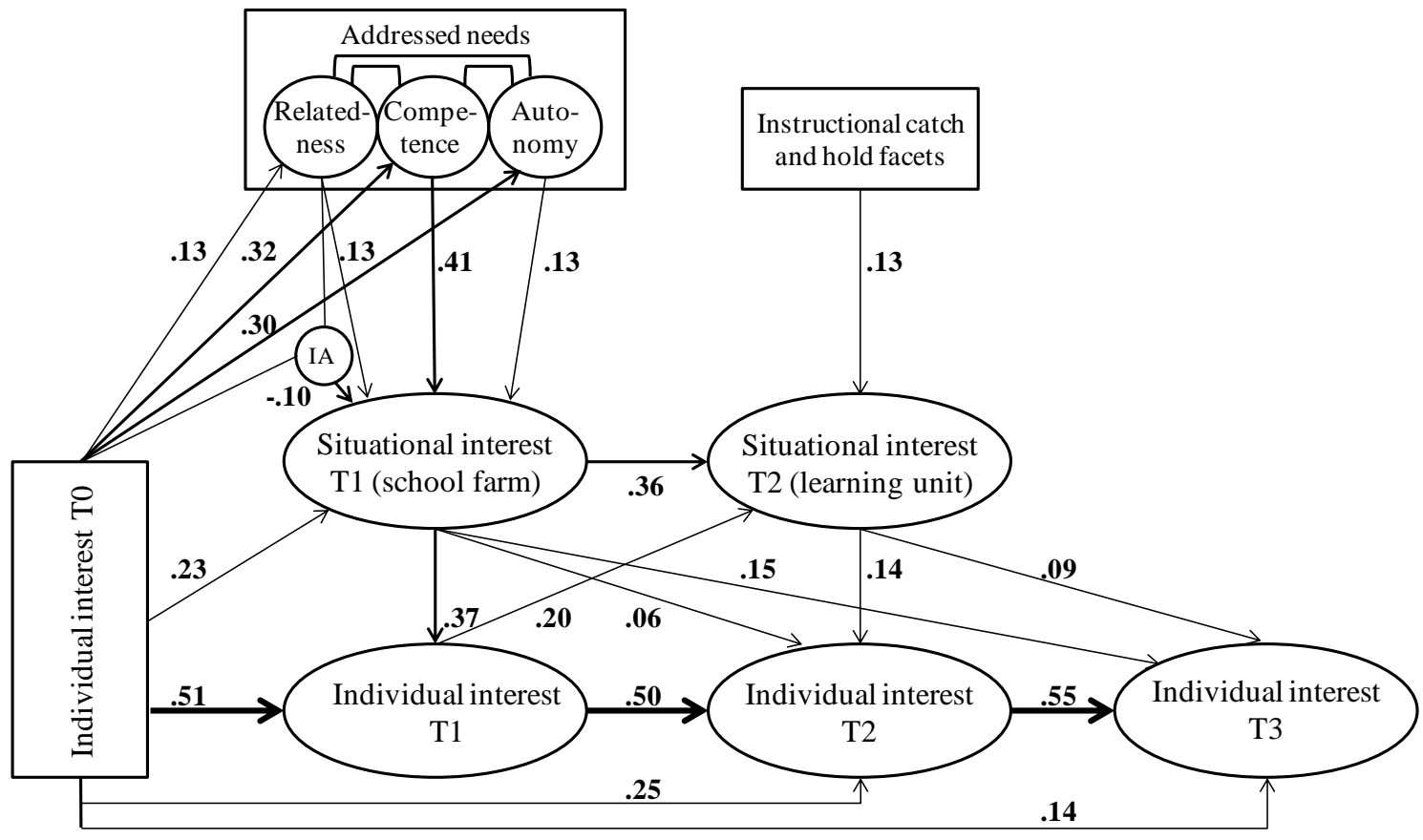

$d f=28, \mathrm{AGFI}=.886, \mathrm{PGFI}=.404, \mathrm{RMSEA}=.072$

Figure 9.4: Influences of perceived autonomy, competence, and social relatedness (T1) and instructional catch and hold elements (T2) on situational interest, and interrelations of situational and individual interest

\subsection{Discussion}

In the frame of theories and models on interest and its development, this study investigated sources of situational interest, as well as reciprocal influences between situational interest and individual interest in agriculture, in an intervention study with four measurement points and two consecutive interventions.

Conforming to hypothesis $1 \mathrm{a}$, the short-term increase in agricultural interest after the school farm program was maintained after a subsequent learning unit in school. This finding supports the importance of integrating extracurricular experiences into the classroom (Dillon et al., 2006), although this study did not use a control group design. However, it was found that interest dropped to the initial level in the medium term (T3, cf. hypothesis $1 b$ ). This phenomenon has also been observed in other studies (e.g., Holstermann et al., 2012).

It seems possible that the decrease in T3 was caused by a lack of further engagements in agricultural content. Most likely, given the high degree of curricular pressure, agriculture was not taught in most of the participating school classes after the end of the learning unit. However, repeated engagements that actively involve students and make them realize the meaningfulness of the topic are necessary to keep students' interests (Hidi \& Renninger, 2006; Mitchell, 1993). 
Another explanation can be annoyance piqued by the repeated measures (Field, 2013). Following this notion, the change at T3 would not necessarily mark a real decline in interest.

Hidi and Renninger (2006) argued that later phases of interest development imply knowledge increases. In this respect, Rotgans and Schmidt (2014) suggested that at least situational interest is nourished and diminishes with growing knowledge. Furthermore, Randler and Bogner assumed that the more people know about an object, the more they are "able to judge whether they are interested" in the object (Randler \& Bogner, 2007, 474). Based on this hypothesized perceptional change, individual interest may have consolidated between T0 and T3 in terms of a (incipient) change from an emerging to a well-developed individual interest (cf. Hidi \& Renninger, 2006). Also, the strong direct links between the individual interest states argue for this explanation (cf. Minnaert et al., 2007).

In line with hypothesis $2 \mathrm{a}$, perceptions of autonomy, competence, and social relatedness were important predictors for situational interest in working on the school farm. In contrast to Skinner and Chi (2012), who found autonomy fulfillment to be most important for engagement in garden work (which can be assumed to be closely related to situational interest), our results suggest the paramount importance of perceived competence. Subjective competence fulfillment had the strongest effect among the three needs and was even superior to prior individual interest in predicting situational interest. The assumption that "students do not require a high sense of their own capability in order to enthusiastically engage in [garden] learning activities" (Skinner \& Chi, 2012, 32) cannot be maintained. School farms put a strong emphasis on practical learning and are likely to promote participants' competence need by providing established, well-adapted, and feasible working units. Thus, it makes sense that perceived competence is the need that correlates most strongly with situational interest.

Additionally, we found that perceived social relatedness is of particular importance for participants with comparatively little prior individual interest. The compensatory interaction effect influencing situational interest at T1 supports the assumption that social relatedness is in particular effective in the process of triggering situational interest (Neubauer et al., 2014). It is likely that social well-being facilitates the willingness to become involved with the school farm tasks and thus pioneers situational interest.

Situational interest in the second intervention in school helped maintain the increased individual interest after T1. Our study was the first to transfer Mitchell's (1993) catch and hold facets from a rather abstract subject to a real-world content area related to education for sustainable development (mathematics vs. agriculture). We found that the applied catch and hold facets were related to situational interest in the 
learning unit. Providing support for hypothesis $2 \mathrm{~b}$, the interplay of catch and hold facets, which were varied across three variants of a scholarly learning unit, had more influence on situational interest than any of the single-facet variants. Thus, also in later phases of interest development, instructional catch elements should accompany hold elements, because situational interest always must be triggered anew. Further results showed that the implementation of the catch and hold elements was well-balanced because none of the one-facetted variants was superior to the other, concerning situational interest.

The path analysis supported the hypothesized interrelations between situational interest and individual interest. The influence of prior states of individual interest on situational interest was suggested (hypothesis 3a); even if the effects were slightly less relevant than in other investigations (Durik \& Harackiewicz, 2007; Harackiewicz et al., 2008; Lewalter \& Willems, 2009; Tsai et al., 2008). On the other hand, situational interest had an impact on individual interest (hypothesis $3 b$ ), albeit the effect size was mostly small (average coefficient of the five paths from situational to individual interest .16). The paths from situational interest at $\mathrm{T} 1$ to individual interest at $\mathrm{T} 2$ and from situational interest at T2 to individual interest at T3 just failed the criterion for a small effect size. Concerning the former, this is not surprising because it can be expected that the effect is overshadowed by the second intervention. With regard to the latter, this may have to do with the comparatively short duration of the in-school intervention (four lessons). Given that the model included the strong paths between the individual interest measures (that are crucial because of the stability of this construct) as well as the three and five weeks' interval between the measures, the proven influence of situational interest on individual interest is considered substantial.

Situational interest in working on the school farm affected individual interest at the same measurement (T1) more strongly than later states of individual interest. This finding supports the fluid character of situational interest. At T1, situational interest had also a stronger immediate effect on individual interest (medium effect size) compared to T2. This is likely due to the longer duration and the more extraordinary experience of the school farm intervention (Stern et al., 2008). Concerning the place, the way of learning (active participation / hands-on), and the instructors, it stands out from regular learning in school. These features did not, or not to the same extent, apply to the second intervention.

With a larger data pool including more school classes, a multilevel modeling approach would have been applied given the data structure of students nested in classrooms. Analysis of the intraclass correlations (ICC, see Appendix B) argued for such a twolevel model; there was a substantial proportion of variance due to class level treatments within the variables that should be affected (situational interest at T1 and T2 as well as individual interest at T1, T2, and T3). However, Maas and Hox (2005) 
suggested a minimum of 50 cases for level two variables in multilevel modeling, which was far beyond the scope of this study.

\subsection{Limitations}

Our study was the first to transfer Mitchell's (1993) catch and hold facets to sustainability-relevant issues in another interest domain combining different research branches concerning sources of situational interest. Yet, it is not without limitations.

i) The applied catch and hold elements were derived from research in other interest domains. We supposed them to be effective because they represent contentindependent instructional elements. Still, it cannot be excluded that other elements would have additional power in the agricultural context.

ii) Our measure of situational interest did not distinguish between triggered and maintained situational interest. Accordingly, it was not possible to directly link the effectiveness of catch and hold elements to the respective phase of situational interest (triggered vs. maintained).

iii) Because our design comprised four repeated measures, we chose to investigate situational interest immediately after the respective intervention to ensure that participants had conducted all tasks. Still, we are aware that situational interest fluctuates throughout the course of instruction (Randler \& Bogner, 2007). Situational interest on the school farm could have been influenced by task sequence throughout the week, in particular by the immediate impression of the task that was conducted last.

iv) We assumed a directed influence from situational interest at T1 (T2) to individual interest at T1 (T2) in the path model. Due to the correlational design of the study, this assumption lacks strong support because both measures were investigated at the same point in time. Yet, we consider this direction of influence appropriate because the measure of situational interest was related to a past occasion (the respective intervention during the past week or day), whereas the measure of individual interest was related to the current moment when filling in the questionnaire. This temporal distinction was made explicit in the questionnaire.

v) This study relied exclusively on self-reports, which is a common practice in interest research (Renninger \& Hidi, 2011). On this basis, our assumptions concerning the shift in the structure of participants' individual interest cannot be supported.

vi) Given the small number of participating school classes, our analysis strategy did not account for class effects.

\subsection{Implications}

Our model of interest development with repeated interventions that considers sources of situational interest as well as interrelations of situational interest and individual 
interest may be the basis for future research in learning contexts with combined extracurricular and in-school interventions. To test the assumption that increasing knowledge consolidates interest in later phases of its development, future research should target the role of knowledge in different phases of individual interest development.

Differentiated measures of triggered and maintained situational interest (cf. Magner et al., 2014) would allow us to test the postulated influence of catch and hold facets in more detail. In general, further systematic investigations concerning the application of catch and hold elements in instructional settings would advance research in this field. Qualitative research (focus groups and interviews) could shed light on students' perceptions concerning the effectiveness of the applied catch and hold facets and identify further elements that trigger and maintain situational interest in agricultural learning contexts and beyond. Future research following a similar research design should strive to integrate more school classes and to apply multilevel analysis to consider possible class effects.

Concerning instructional practice, our findings suggest that the perception of autonomy, relatedness, and mainly competence are important for situational interest in working on school farms. Thus, it is also advisable that other educational farms enable conditions to suit these needs. This could be accomplished by offering practical tasks and clear goals within the learners' reach to foster their sense of competence. To involve participants with little prior interest in agriculture, the farm conditions should foster the feeling of social belonging, e.g., through cooperative learning in small groups (cf. Durlak, Weissberg, Dymnicki, Taylor, \& Schellinger, 2011). More research to clarify the role of the basic needs related to the process of triggering and maintaining situational interest is desirable.

Appendix A: Realized and intended number of participating school classes according to grade of school, school track, and visited school farm within the three variants of the second treatment

\begin{tabular}{lrccc}
\hline & & $\begin{array}{c}\text { Catch-only } \\
\text { Realized (intended) number of school classes }\end{array}$ \\
\hline Grade of school & fifth grade & $1(2)$ & $3(2)$ & $2(2)$ \\
& sixth grade & $2(2)$ & $-(2)$ & $1(2)$ \\
\hline School track & gymnasium & $2(2)$ & $1(2)$ & $1(2)$ \\
& secondary school & $1(2)$ & $2(2)$ & $2(2)$ \\
\hline Visited school farm & $\mathrm{A}$ & $1(1)$ & $1(1)$ & $2(1)$ \\
& $\mathrm{B}$ & $1(1)$ & $1(1)$ & $-(1)$ \\
& $\mathrm{C}$ & $1(1)$ & $-(1)$ & $-(1)$ \\
& $\mathrm{D}$ & $-(1)$ & $1(1)$ & $-(1)$ \\
& $\mathrm{E}$ & $-(-)$ & $-(-)$ & $1(-)$ \\
\hline
\end{tabular}


Appendix B: ICC coefficients:

Autonomy: $\quad 099$

Competence: .059

Relatedness: .073

Individual interest T0 *Relatedness: .034

Situational interest T1: $\quad .134$

Situational interest T2: $\quad .239$

Individual interest T0: .042

Individual interest T1:.158

Individual interest T2:.157

Individual interest T3:.131

(ICC coefficients of .10 are deemed small and coefficients of .20 medium effect size; Chen, 2012, p. 3) 


\section{Summary and Discussion}

This chapter briefly summarizes and discusses the central outcomes of this study (10.1 - 10.5). Some methodological issues of the empirical contributions are given consideration in chapter 10.6. The chapter closes with concluding remarks concerning future research on agricultural interests (10.7).

\subsection{Measuring Agricultural Interests}

Building a prerequisite for all further investigations on agricultural interests in this thesis, the first aim of this study was to develop a valid and reliable instrument to measure different agricultural interests. The instrument was supposed to meet theoretical conceptions of individual interest and to comprise various discrete content areas that altogether represent agriculture for fifth and sixth graders.

To meet the first criterion, the interest scale was based on an existing scale that had demonstrated reliability and validity in other interest domains (Schiefele \& Krapp, 1996; Schiefele, 1990b, 1991). The items were adapted to a bipolar answering format in order to shorten the instrument. They represent affective and value-related components of individual interest and are each related to five agricultural content areas. The content areas should link to the perspective of fifth and sixth graders. They were chosen in regard of theoretical considerations concerning elementary branches of agriculture (Meinzen-Dick et al., 2012; Rubenstein, 2010; Vonderach, 2004). Finally, the content areas comprised animal husbandry, arable farming, vegetable and fruit cropping, primary food processing, and agricultural engineering. A recent study proved that the four most frequent mentioned conceptions of agriculture to be found with German fifth and sixth graders are animals, processing, technology, and plants (Fröhlich et al., 2013). This finding emphasizes that the chosen content areas are welladjusted to the target group in the present study.

Basing on exploratory factor analysis and qualitative feedback of the participants, a pilot study ( $N=115$, cf. chapter 6 ) extracted four of the six initial interest items to measure individual interest in each of the five content areas (cf. Appendix 1). The analysis suggested that the affective and the value-related components of individual interest cannot be distinguished empirically. This corresponds to Schiefele who developed and applied the original scale in various studies (Schiefele, Krapp, Wild, \& Winteler, 1992; Schiefele \& Krapp, 1996; Schiefele, 1990a, 1990b, 1991, 1992, 1996). However, as intended, the five agricultural content areas were clearly distinguished and each represented by one discrete factor.

The second empirical contribution ( $N=1,085$, cf. chapter 7$)$ further validated the factorial design of the agricultural interests scale. By means of a variance decomposition confirmatory factor analysis, the distinction between the five content areas was validated being the strongest variance source within the instrument 
(contributing more than $50 \%$ of item variance). In addition, a general factor (representing general interest in agriculture) was extracted accounting for almost a quarter of item variance. The distinction between the components of individual interest was significant but compared to the other variance sources negligible $(5.5 \%)$.

The developed instrument (Appendix 1) was not only necessary for further steps in this study but can serve as a sound basis for future research concerning agricultural interests. It is an adequate measure that grounds on interest theory; in this respect, its interest components-that can be viewed as separate but correlated facets-represent individual interest. Besides, it comprises different elementary branches of agriculture and thus allows analyzing agricultural interests on a superordinate (due to the general factor) and on a differentiated level (according to the content areas). The instrument was validated on a methodologically high level (exploratory and confirmatory factor analyses). The overall scale as well as the content area subscales indicated excellent reliabilities.

\subsection{Explaining Agricultural Interests}

Prior research did hardly focus on agricultural interests and there were no results concerning influence factors to be found. Thus, the second objective of this study was to explain agricultural interests (without any prior treatment) by evaluating influence factors. The second empirical contribution dealt with this issue (chapter 7). As there were no prior results concerning influence factors of agricultural interests, the choice of potential factors was informed by research concerning related interest domains. The predictor set embraced gender, garden experience (representing nature experiences in home gardens), frequency of farm visits, agriculture-related prior knowledge, and disgust sensitivity.

Stepwise multiple regression analyses scrutinized whether and to what degree these factors could explain interest in agriculture and its content areas: animal husbandry, arable farming, vegetable and fruit cropping, primary food processing, and agricultural engineering. Keeping a pet at home was included as an additional predictor for the specific interest in animal husbandry. The mean score off all 20 items was computed as general interest in agriculture. Besides, an ipsatized mean score was computed (by subtracting the score of general agricultural interest) for the interest specificity within each content area comprising four items each. Thus, general and content area specific influence patterns were observed.

Prior knowledge, garden experience, and disgust sensitivity (with a negative impact) influenced general interest in agriculture. Besides these overall predictors, the following further influence patterns concerning the interest specificities of the content areas were found: 
- Gender affected the interest in all content area specificities except for arable farming. Girls were more interested in animal husbandry, vegetable and fruit cropping, and primary food processing. Boys had a considerably higher interest in agricultural engineering.

- Keeping a pet determined the interest specificity in animal husbandry.

- Frequency of farm visits determined the interest specificity in arable farming.

- Disgust sensitivity determined the interest specificity in arable farming (reinforcing the negative influence being affective through general interest).

- Garden experience determined the interest specificity in vegetable and fruit cropping (reinforcing the influence being affective through general interest).

- Prior knowledge determined the interest specificity in primary food processing (weakening the positive influence being affective through general interest).

The results are in line with other studies. There is empirical evidence that girls are more interested in animals than boys (Finke, 1999; Jones et al., 2000); contrariwise, boys are generally more inclined to engage in technical aspects (Baram-Tsabari \& Yarden, 2009; Cakmakci et al., 2012; Holstermann \& Bögeholz, 2007; Jones et al., 2000; Schreiner, 2006). Prior knowledge seems to be "universally" related to interest irrespective of the particular interest domain (e.g., Alexander et al., 1995). Also the importance of nature experiences for nature-related interests is supported by several studies (Cheng \& Monroe, 2012; Kals et al., 1999; Leske \& Bögeholz, 2008). Our findings stress the benefit of active nature experiences, since (active) garden experience was more meaningful than (assumingly rather observing) farm visits. Basing on these insights, active farm experiences are assumed to have great potential regards the process of interest development in the agricultural context. However, typical agricultural disgust stimuli may have an opposite effect and should be taken seriously (Holstermann et al., 2012).

\subsection{Gender-specificity within Agricultural Interests and the Impact of School Farms}

The results of this study support strong evidence for a gender-specificity within agricultural interests. Three out of four empirical contributions dealt with this issue. The studies presented in chapter 6 and 7 confirmed gender differences in the initial agricultural interests. The findings stated in chapter 8 proved that the effect of school farms on agricultural interests varies according to gender.

The first contribution (chapter 6) found gender differences within the initial agricultural interests in a pre-study with 115 participants. Likewise, gender was an important predictor of agricultural interests in the main study $(N=1.085)$ as is documented in the second empirical contribution (chapter 7 ). The results of both studies are coherent to a large degree. There does not seem to be a gender difference 
concerning general interest in agriculture. However, the results proved gender differences concerning interest in

- vegetable and fruit cropping with small effect size (in favor of girls),

- animal husbandry with medium effect size (in favor of girls),

- agricultural engineering with large effect size (in favor of boys), and

- primary food processing with medium effect size (in favor of girls) ${ }^{24}$.

The found gender-specific patterns within interest in agricultural content areas reflect prior findings concerning related interest objects such as general interest in animals, technology, and nutritional issues (Baram-Tsabari \& Yarden, 2009; Cakmakci et al., 2012; Finke, 1999; Grunert et al., 2010; Holstermann \& Bögeholz, 2007; Jones et al., 2000; Schreiner, 2006).

Keeping the gender-specificities concerning agricultural interests in mind, the results of the third study (chapter 8 ) are striking. The study investigated the potential of a five-day school farm stay to increase general interest in agriculture and interest in the five content areas across fifth and sixth graders. A control group without any treatment was included. The regression analyses were conducted for boys and girls separately and included two predictors. Firstly, the overall impact of the school farm stay (experimental group vs. control group); secondly, the influence of the participants' active work experiences during the farm stay gained by various agricultural activities (related to the observed content areas). For instance, it was analyzed whether active work experience with animals had an influence on interest in animal husbandry. In the same way, the influence of work experience was analyzed concerning interest in vegetable and fruit cropping, primary food processing, and the general interest in agriculture (here, an aggregated score of the overall work experience in all applying content areas was used). Students' work experience in arable farming and agricultural engineering did almost not occur and could thus not be included in the respective analyses.

The school farm stay and the respective work experiences favored boys' interests in agriculture and all content areas (concerning agricultural engineering the effect was only significant with $p<.10$ ). By contrast, the agricultural interests of girls did not increase. Only their interest in animal husbandry was enhanced by active work experience in this field. Thus, the results show that learning on school farms represents a way to address the agricultural interests of boys in particular. From a pedagogical point of view, this is a remarkable result because research has shown that in general girls tend to be more strongly interested in school matters than boys (Diprete \&

24 This result was found in the main study (chapter 7 ) involving a much larger sample than the pre study (1.085 vs. 115 participants). 
Buchmann, 2006; Freudenthaler, Spinath, \& Neubauer, 2008; Legewie \& DiPrete, 2009). This holds also true for most of the initial agricultural interests as mentioned before. School farm stays with the respective work experiences provide one approach to reduce this gap and thus offer a boy-friendly learning environment as called for by researchers and educators (King \& Gurian, 2006; Lekies \& Sheavly, 2007).

Different factors are possible to explain the gender-specific outcomes of school farm learning. Chapter 9 revealed that situational interest in working on a farm is an important predictor of individual interest in agriculture. Thus, it seems likely that boys had a higher situational interest in farm work that in turn influenced their individual interest rates in the agricultural content areas after the farm experience. However, this is not true. Indeed, girls showed higher rates of situational interest, as further analyses revealed $\left(M_{\text {boys }}=3.95, M_{\text {girls }}=4.26, p<.001, d=.38\right)$. This underlines that a school farm stay also has positive effects for female participants in terms of their immediate motivational response.

Despite indicating less situational interest in the farm works, boys profited more from the school farm experiences than girls concerning individual interest in most agricultural content areas. Thus, it appears likely that the manifold active work experiences in the different agricultural content areas influenced boys on a deeper level beyond the actual interestedness in the current activities. Apparently, physically challenging types of extracurricular environmental education provide an adequate approach to encourage boys (cf. Carrier, 2009; Gurian \& Stevens, 2010; King \& Gurian, 2006; Özden, 2008). Maybe the physically challenging school farm experiences are an appropriate contrast for boys to the cognitively-oriented way of learning in school that girls can usually better cope with (Duckworth \& Seligman, 2006; Matthews et al., 2009).

Besides, ceiling effects might have influenced the gender-specific results concerning the impact of school farms on students' agricultural interests. Ceiling effects are inherent to rating scales, in particular when applied to studies with a repeated measures design (Bortz \& Döring, 2006). For instance, Guderian (2007) observed ceiling effects concerning interest in physics. In the present study, a four-point rating scale for individual interest was applied. Due to the higher initial interest rates of girls in most agricultural content areas (cf. chapter 6 and 7), ceiling effects are more likely for them. The considerable share of female participants rating the maximum score of initial individual interest in animal husbandry, primary food processing, and vegetable and fruit cropping (cf. Table 10.1), ceiling effects cannot be excluded. Yet, despite the large proportion of female participants with a maximum initial interest in animal husbandry, girls with work experience concerning animals still increased their interest in this content area. Thus, ceiling effects cannot totally explain why girls did not increase rates in other agricultural interests after the farm stay. 
As to boys, ceiling effects appear to be a possible explanation for the comparatively weak increase in their interest in agricultural engineering after the farm stay. For girls and boys, ceiling effects regards arable farming are not very likely.

Table 10.1: Percentage of participants in the experimental group with maximum (minimum) initial interest (T0) in the agricultural content areas

\begin{tabular}{lcc}
\hline & $\begin{array}{c}\text { Girls (\%) } \\
n=410^{1}\end{array}$ & $\begin{array}{c}\text { Boys (\%) } \\
n=386^{1}\end{array}$ \\
\hline Animal husbandry & $67.8(0.7)$ & $35.8(0.8)$ \\
Arable farming & $14.4(4.9)$ & $18.9(5.2)$ \\
Vegetable and fruit cropping & $23.2(2.2)$ & $15.8(6.0)$ \\
Primary food processing & $43.2(1.0)$ & $22.0(3.9)$ \\
Agricultural engineering & $12.4(11.2)$ & $49.2(4.1)$ \\
\hline The analysis comprises students who filled out T0 and T1 questionnaires (cf. chapter 8)
\end{tabular}

Apart from the gender-specificity, another striking outcome was achieved in the analyses of the school farm effects. Pretest evaluations disclosed that participants that were going to visit a school farm indicated a higher general interest in agriculture than participants of the control group $(p<.001, d=.37)$. This phenomenon can be due to students' anticipation of the forthcoming event (for similar results cf. Bogner, 1998). In this light, it seems likely that the baseline score of participants enrolled in the school farm program were "artificially" heightened. There are neither other plausible explanations nor differences concerning personal characteristics between both group members that could explain this phenomenon.

In light of the possible ceiling effects and the probable anticipation of participants enrolled in the school farm program, it can be doubted whether the results expose the full potential of school farms to foster agricultural interest.

\subsection{The Impact of School Farm Experiences and Instructional Catch and Hold Elements in Curricular Learning Units on Situational Interest}

In the present thesis situational interest was investigated at the end of two consecutive treatments; the first being a five-day school farm stay with active agricultural work experiences, the second an agricultural learning unit in school comprising two doubleperiods. The study presented in chapter 9 investigated different factors that influenced situational interest ratings during both treatments.

The influence of basic need fulfillment for situational interest on the school farm: In keeping with Krapp (2002b), participants' basic need fulfillment (Deci \& Ryan, 1985; Deci, 1998) influenced their situational interest in working on the school farm. Most powerful was perceived competence, which means the sense of one's own ability to accomplish tasks and to reach goals. The perception of autonomy and social relatedness also added to situational interest on the school farm. The latter was of 
particular importance for participants with comparatively low initial individual interest in agriculture. The cooperation with peers and staff members on the school farm appears to be an important aspect to involve learners with low prior agricultural interest in the current activities.

Recent research suggested that the relative importance of the perceived basic needs for situational interest depends on the content, the instructional design (cf. Reinmann \& Mandl, 2006), and the educational context of the learning situation (Neubauer et al., 2014). In contrast to Skinner and Chi (2012), who found perceived autonomy to be most important for engagement in garden work, competence fulfillment was the most powerful basic need for situational interest in the present study (cf. chapter 9). Different reasons may explain this discrepancy. First, the applied dependent variables were not identical (situational interest vs. engagement). However, the operationalization of engagement in gardening (cf. Skinner \& Chi, 2012, p. 20) shows many similarities to the applied situational interest construct of the present study. Differences concerning the educational context and the instructional designthat appear to be closely related at first glance-seem to be more likely for the varying relative influence of perceived autonomy and competence in both studies. The garden education program in Skinner and Chi's study did not only focus on practical tasks. It also included cognitive activities of coordination and planning. Participation in such activities means participating in decision-making processes, which may address participants' sense of autonomy.

School farm instruction, on the other hand, clearly focuses on practical experience. It provides hands-on work experiences in manifold fields of agriculture. Throughout the whole farm stay, the students conduct practical agricultural jobs that are designed to allow for a maximum of manual labor. The participants are actively involved wherever possible-e.g., while milking cows, planting vegetables, baking bread, or threshing grain. The jobs are within the learners' reach, and the necessity as well as the practical results of the jobs are self-evident. The outcomes are more visible compared to those of abstract activities. In this regard, it is very likely that the need for competence was particularly addressed by the school farm treatment (cf. Krogh \& Jolly, 2012).

The importance of catch and hold elements for situational interest in the curricular learning unit: The design of the second treatment was based on Mitchell's (1993) model of situational interest that comprises different instructional elements to trigger (catch) and to maintain (hold) situational interest. The elements that Mitchell extracted in the mathematical classroom were applied to an agricultural context. The treatment included two curricular valid double periods. The first of which included a comparison of different housing systems for laying hens; the second centered on potato production, diversity of potato varieties, and the usage of potatoes in the foods and commodities of daily life. The entire learning unit was developed in three different variants that 
systematically varied catch and hold elements while the content of the units was kept constant. Accordingly, a catch-only, a hold-only, and a combined catch and hold variant were realized (chapter 9.3.4). In agreement with prior research (Durik \& Harackiewicz, 2007; Magner et al., 2014; Mitchell, 1993; Silvia, 2005b, 2010), catch elements contained social, visual, and cognitive stimuli. Hold elements were operationalized through active involvement and meaningfulness (Mitchell, 1993). As expected, the treatment with catch and hold elements resulted in higher rates of situational interest than both single-facet variants. In comparison of the treatments with only catch or hold elements, none was superior to the other.

The results show that concrete learning situations profit from integrating catch- and hold-elements in terms of situational interest. This is not only valid for instruction that introduces a new topic but also for later phases of interest development after preceding occupations with the object of interest. Here, it becomes apparent why the term situational interest is referred to as such: it depends on situational conditions and needs to be triggered anew in all phases of learning and individual interest development.

The relation of the basic needs to catch and hold processes: Previous research has hardly considered whether basic need fulfillment is more effective in the catch or in the hold phase of situational interest. This study deems perceived social relatedness particularly crucial for triggering situational interest because participants with comparatively low initial individual interest profited more from relatedness fulfillment than others. This is in line with prior research that extracted group work as a catch element (Mitchell, 1993). Group work enables strong learner interaction and may thus address social relatedness (Gräsel \& Gruber, 2000). Also recent findings of Neubauer et al. (2014) suggested that the perception of social relatedness during a guided museum tour predominately influenced situational interest in the triggering phase.

There were no indications that perceived competence or autonomy was of particular importance for catching or holding situational interest.

\subsection{The Model of Agricultural Interest Development}

In chapter 9, a model of interest development for learning contexts with consecutive extracurricular and curricular treatments was introduced. The model combined different theoretical branches of interest research. It considered the development of individual interest over four measurement points, including a pre-measurement, two consecutive interventions, and a follow-up measure. The first extracurricular treatment was followed by a second intervention in school because frequency and duration of treatments determine the development of individual interest (Hidi \& Renninger, 2006). In addition, the effectiveness of extracurricular treatments is enhanced if the experiences made are integrated in the classroom (e.g., Dillon et al., 2006). Situational interest during both 
treatments was supposed to influence the following states of individual interest (e.g., Linnenbrink-Garcia et al., 2010). In turn, prior rates of individual interest ought to foster the emergence of situational interest (e.g., Harackiewicz et al., 2008). Moreover, situational interest in the extracurricular treatment was expected to profit from basic need fulfillment (competence, autonomy, and social relatedness; Deci, 1998; Krapp, 2005). Situational interest in the second treatment was influenced by instructional elements (Mitchell, 1993). The model represents an innovative synthesis comprising the different theoretical aspects of interest research mentioned that have mostly been scrutinized separately so far.

The model was applied in the context of agricultural learning with a five-day school farm stay as first treatment. The second curricular treatment comprised two double lessons in school taking on the farm experience made. The model was confirmed with reasonable fit indices. The reciprocity of individual and situational interest was proved as well as basic need fulfillment and the catch and hold elements as sources of situational interest (as was already discussed in paragraph 10.4). Conforming to the hypothesis, individual interest in agriculture increased after the school farm stay and was maintained on this level after the learning unit in school (see chapter 9.4.1). This finding underlines the importance of integrating extracurricular experience in the classroom. However, at the follow-up measurement the interest decreased to the basic level of the pre-measurement as described in chapter 9. Different reasons for that interest decline can be considered.

Fatigue or boredom effect: Students could have been annoyed by repeatedly filling out the same questionnaire (Field, 2013). At the baseline measure they might have been motivated to fill out the questionnaire since it was new to them. The two subsequent measurements accompanied the treatments on the school farm and in school. The last measurement however, had no obvious "reason". Thus, participants might have been tempted to quickly fill out the questionnaire without seriously ticking the items and thus causing bias.

Lack of further object engagement: The last measurement was conducted five weeks after the second treatment in school. Since teachers have to fit many different topics into every school year in order to comply with the curriculum, it is likely that most teachers changed over to another topic in the science classroom after the learning unit. This assumption is also supported by the results of curricular analyses for agricultural content that is mostly not compulsory (cf. chapter 2.2). A lack of further engagement with agricultural content may have caused the decline at T3 (Hidi \& Renninger, 2006; Mitchell, 1993)

Perceptional change concerning agricultural interest: According to theory, the structure of individual interest changes during its development and learners accumulate increasingly object-related knowledge in later states (Hidi \& Renninger, 2006). This 
may have implications on the findings of the present study. The instrument to measure individual interest in agriculture grounded on affective and value-oriented components of individual interest (cf. Schiefele \& Krapp, 1996). This conceptualization does not imply a knowledge component since it is based on the assumption that interest and knowledge represent correlated but distinct constructs (Schiefele, 2009). Thus, claims concerning an actual knowledge increase of the participants cannot be proved on an empirical basis. However, such a knowledge increase seems to be likely as to the comprehensive treatments on the school farm and in school. In this respect, studies have shown that a knowledge increase can lead to decreasing (situational) interest due to a satisfaction of the "thirst for knowledge" (Rotgans \& Schmidt, 2014, p. 37). Besides, knowledge gains can imply a perceptional change towards the object of interest and the interest itself. Taking the improved individual knowledge base for granted, one's own interest can be judged more realistically and the estimation may deviate from prior estimations (Randler \& Bogner, 2007). This phenomenon may be true in particular for interest objects that participants have not been familiar with before. As outlined in chapter 2.1, nowadays this holds for most fifth and sixth graders, who usually have little relation to agriculture in their daily life. Against this background, a real interest decline at the follow-up measurement can be challenged. 


\subsection{Methodological Reflections}

Concerning the measurement and the development of individual interest, the possibility of ceiling effects have already been discussed regards the initial agricultural interests and the interest increase at $\mathrm{T} 1$, respectively (cf. chapter 10.3). Besides, a possible perceptional change concerning agriculture and participants' agricultural interest based on both interventions was discussed (cf. chapter 10.5). Some further aspects may be relevant.

Teacher effects: The school classes that participated in this study were recruited via the cooperating school farms. Since the teachers deliberately chose to visit a school farm, it is possible that the class teacher's decision for a school farm stay was based on their positive attitude towards agriculture. Research has shown that teachers can serve as role models and their attitudes may have an influence on their students (Osborne et al., 2003). For this reason teacher effects cannot be excluded.

A teacher effect might also have been particularly relevant concerning the treatment in school. Each of the three variants of the learning units comprised three school classes. Since the class teachers conducted the lessons, a teacher effect could have had a bearing on the results. This may be particularly valid concerning the measure of situational interest, which is directly related to the lessons and the individual style of teaching (Rotgans \& Schmidt, 2011b).

Anticipation bias: The first measurement of individual interest in agricultural content areas was conducted two weeks prior to the farm stay. The results showed that participants within the experimental group indicated higher initial interest ratings than control group members. This phenomenon is likely due to the anticipation of the forthcoming farm stay and has been observed in other studies with close intervals between pre-measurement and treatment (e.g., Bogner, 1998).

Static situational interest measure: This study applied a situational interest measure at the end of both treatments. Research has shown that situational interest fluctuates throughout the course of instruction (Holstermann et al., 2012; Rotgans \& Schmidt, 2011a). More precise results can be achieved by assessing situational interest during different instructional phases (Holstermann et al., 2012; Linnenbrink-Garcia et al., 2010; Rotgans \& Schmidt, 2011a). For instance, the influence of catch and hold elements could be directly linked to different states of situational interest as well as the basic need fulfillment.

Catch and hold elements: The applied catch and hold elements were based on prior studies in the field of situational interest (e.g., Durik \& Harackiewicz, 2007; Mitchell, 1993). The present study did not include a preliminary step to extract potential contentspecific catch and hold elements as to the agricultural context (cf. Mitchell, 1993). 
Lack of control group in testing catch and hold elements: It has to be acknowledged that the variants of the learning unit in the second treatment did not include a control group. Three variants with catch-only, hold-only, and combined catch and hold elements were realized. A variant without catch and hold elements was not included. Thus, the assumption that any of the three variants with catch and / or hold elements results in a higher situational interest in comparison to a variant without any additional catch or hold element could not be verified.

The participating teachers made a great contribution to this study in spending a remarkable share of their teaching time for the investigations. However, it was difficult to win teachers over to additionally participate in the second treatment at all. Most teachers rejected participation due to curricular pressure and time constraint. Thus, to convince them to participate in the learning unit in school-which meant they would have to give the prepared lessons according to our instructions-it was appropriate to provide attractive and interest-conveying lessons. Even if they were not informed about the different variants beforehand a version of the learning unit without catch and / or hold elements would apparently not have been attractive.

\subsection{Concluding Remarks and Prospects}

To briefly summarize, this study provided a thorough insight into fifth and sixth graders agricultural interests and the potential of school farms and subsequent curricular learning about agriculture to foster agricultural interests. Generally, students' interests differed between different agricultural content areas and were subject to a genderstereotypical differentiation. Five-day school farm stays involving active work experiences in various agricultural fields increased most of the agricultural interests, in particular for boys. A subsequent learning unit in school maintained the increased interest levels that dropped again at the follow-up measure, however. In particular competence, but also autonomy, and social relatedness were important to promote situational interest on the school farms. A systematic comparison of different variants of the subsequent learning unit in school demonstrated that instructional catch and hold elements should be combined in order to promote situational interest. Concerning the process of individual interest development in agriculture, close interrelations between states of situational and individual interest are suggested.

Application of the agricultural interest scale: The developed instrument to measure interest in different agricultural content areas may serve for future research. If applied to older students, the content areas could be adapted and integrate more cognitively demanding aspects, such as different agricultural system strategies (e.g., conventional vs. organic farming) or environmental impacts of agricultural production (e.g., concerning biodiversity and greenhouse gas emissions) (cf. Hubert et al., 2000). 
Application of the proposed model of agricultural interest development: The proposed model of agricultural interest development with two consecutive extracurricular and curricular treatments may serve future research. Its novel character is based on the synthesis of various branches of interest research that have not been combined before in this way. It considers reciprocal influences of situational and individual interest. So far, the relation of these variables has mostly been studied in one or the other direction of influence only (e.g., Linnenbrink-Garcia et al., 2010). Different theoretical approaches to promote situational interest are also included: perceptions of competence, autonomy, and social relatedness are incorporated in the extracurricular treatment (Deci, 1998). This was intended because the extracurricular treatment is an extraordinary experience in comparison to daily school life. Thus the quality of the learners' situational experience is particularly striking (Krapp, 2002b). Catch and hold elements are included in the second treatment, because they can be deliberately varied by teachers (Mitchell, 1993).

The application of the model is not restricted to the agricultural context. It can be applied to different learning contexts within the frame of education for sustainable development and environmental education.

Suggestions for future research: Concerning future research on agricultural interest and the role of school farms, the concrete farm conditions could be investigated by accompanying qualitative measures in a mixed-measures approach (Gläser-Zikuda, Seidel, Rohlfs, Gröschner, \& Ziegelbauer, 2012). Thus, potential differences between farms could be given consideration. In addition, more elaborated analysis techniques such as multi-level modeling could be applied in order to consider farm characteristics, class effects, and individual aspects.

Qualitative methods such as expert interviews with agricultural educators or focus groups with learners in agricultural education (cf. Flick, 2013) could help to extract more specific instructional elements to trigger and maintain situational interest in agricultural learning. Furthermore, studies could include other concepts, e.g. ones that involve repeated learning occasions on farms over a longer period of time (e.g., one school year) or learning occasions in the immediate context of the school itself (such as school gardens). Such approaches that continuously involve students in hands-on agricultural learning might be appropriate to foster agricultural interest in the long run.

Concerning the development of individual interest in formerly unfamiliar content areas, it appears promising to relate the process of interest development to the one of knowledge about the interest object (Renninger \& Hidi, 2011). Such an approach could help to explain potential decreases in interest at the follow-up measurement, which are assumed to be (partially) due to a perceptional change (Randler \& Bogner, 2007).

The present study suggested that perceived social relatedness is predominantly effective in the process of triggering situational interest. Future research should further 
advance the understanding of how the basic needs relate to the processes of triggering and maintaining situational interest.

Suggestions and prospects concerning educational practice: The importance of extracurricular learning on farms as well as its combination with classroom activities has been shown in this study. Thus, the importance of hands-on agricultural learning on farms is emphasized. Still, it is a challenge to maintain agricultural interests in the medium and long term. Children and adolescents have usually not much contact to agriculture in their daily life that would help to keep this interest alive. Consequently, repeated engagements with agricultural topics in formal education would be desirable to further develop learners' agricultural interests (Hidi \& Renninger, 2006).

To guarantee a continuous learner engagement with agricultural content in school, profound curricular changes would be necessary. In the context of a debate on agricultural literacy in the US, Hubert et al. (2000) have demanded the integration of agricultural content from kindergarten to year twelve in school. In this context, the "Living Learning" project in Norway may serve as a role model. This project integrates agricultural content and practical experience throughout ten years of school in the frame of a local school-farm cooperation (Krogh \& Jolly, 2011, 2012). Such a combination of lasting extracurricular and curricular learning allows for continuous engagement with agricultural content including practical hands-on and cognitive mindson learning. It might be a way to ingrain agricultural interest within learners in the long run.

In order to meet the sustainable development goals that are related with agriculture, Hubert et al. (2000, p. 526) advocate for broadening the subject matter to "utilization of environmental and resource management". This would comply with the convention on biodiversity that calls for more educative approaches concerning education on biodiversity (CBD, 1992, article 13). Such complex and important issues demonstrate that agriculture provides an area of learning that also suits older students. Targeting issues such as biodiversity and its relations to agriculture presuppose a basic agricultural education in earlier years of school, which school farms can achieve to make an important contribution to. 


\section{References}

Aiken, L. S., \& West, S. G. (1993). Multiple regression: Testing and interpreting interactions. Newbury Park: Sage.

Ainley, M., \& Ainley, J. (2011). A cultural perspective on the structure of student interest in science. International Journal of Science Education, 33(1), 51-71.

Alexander, P. A., \& Jetton, T. L. (1996). The role of importance and interest in the processing of text. Educational Psychology Review, 8(1), 89-121. doi:10.1007/BF01761832

Alexander, P. A., Jetton, T. L., \& Kulikowich, J. M. (1995). Interrelationship of knowledge, interest, and recall: Assessing a model of domain learning. Journal of Educational Psychology, 87(4), 559-575. doi:10.1037/0022-0663.87.4.559

Alexander, P. A., Kulikowich, J. M., \& Jetton, T. L. (1994). The role of subject-matter knowledge and interest in the processing of linear and nonlinear texts. Review of Educational Research, 64(2), 201-252. doi:10.3102/00346543064002201

Baard, P. P., Deci, E. L., \& Ryan, R. (2004). Intrinsic need satisfaction: A motivational basis of performance and well-being in two work settings. Journal of Applied Social Psychology, 34(10), 2045-2068. doi:10.1111/j.15591816.2004.tb02690.x

Baram-Tsabari, A., \& Yarden, A. (2009). Identifying meta-clusters of students' interest in science and their change with age. Journal of Research in Science Teaching, 46(9), 999-1022. doi:10.1002/tea.20294

Baumert, J., Köller, O., Hoffmann, L., Krapp, A., Renninger, K. A., \& Baumert, J. (1998). Interest research in secondary level II: An overview. In Interest and learning - Proceedings of the Seeon Conference on Interest and Gender (pp. 241-256). Kiel: IPN.

Bergin, D. A. (1999). Influences on classroom interest. Educational Psychologist, 34(2), 87-98. doi:10.1207/s15326985ep3402_2

Bickel, M. (2006). Ernährungsbildung auf Schulbauernhöfen - exemplarische Untersuchungen auf drei Schulbauernhöfen [Nutritional education on school farms - exemplary investigation on three school farms] (Diplomarbeit). Universität Kassel / Witzenhausen.

Bickel, M., \& Bögeholz, S. (2013a). Landwirtschaft als Bildungsgegenstand: Lernziele, Lerngelegenheiten auf Schulbauernhöfen, Schülerinteressen und Lernpotentiale [Agriculture as educational topic: Educational aims and opportunities on school farms, pupils' interests and learning potentials]. In D. Haubenhofer \& I. Strunz (Eds.), Raus auf's Land - Landwirtschaftliche Betriebe 
als zeitgemäße Erfahrungs- und Lernorte für Kinder und Jugendliche (pp. 117138). Baltmannsweiler: Schneider Hohengehren.

Bickel, M., \& Bögeholz, S. (2013b). Schülerinteressen an landwirtschaftlichen Themen [Pupils' interests in agricultural topics]. In J. Friedrich, A. Halsband, \& L. Minkmar (Eds.), Biodiversity and Society. Societal dimensions of the conservation and utilization of biological diversity (pp. 59-72). Göttingen, Germany: Universitätsverlag Göttingen.

Bickel, M., Strack, M., \& Bögeholz, S. (2014). Measuring the interest of German students in agriculture: The role of knowledge, nature experience, disgust, and gender. Research in Science Education, online first. doi:10.1007/s11165-0149425-y

Bickel, M., Strack, M., \& Bögeholz, S. (resubmitted). The potential of school farms to foster students' interests in agriculture: A "boy-friendly strategy."

Binswanger, H. (1986). Agricultural mechanization - A comparative historical perspective. The World Bank Research Observer, 1(1), 27-56. doi:10.1093/wbro/1.1.27

Bischopink, B., \& Brandes, P. (2002). Analyse der Rahmenrichtlinien/Lehrpläne (Primarstufe, Sekundarstufe I, gymnasiale Oberstufe) zu landwirtschaftlichen Themenbereichen in der Bundesrepublik Deutschland 2002 [Analysis of German curricula (primary school, lower and upper secondary school) according to agricultural contents] (p. 195). Altenkirchen: Bundesarbeitsgemeinschaft Lernort Bauernhof e.V. Retrieved from http://www.lernenaufdembauernhof.de/fileadmin/user_upload/Zusammenfassun g_RRL_3_02_2003.pdf

Bittner, A. (2003): Außerschulische Umweltbildung in der Evaluation: Wirkungen kurzzeitpädagogischer Maßnahmen auf Umwelt- und Naturschutzinteressen von Schülerinnen und Schülern der Sekundarstufe I [Evaluating extracurricular environmental education: Impacts of short-term pedagogical measures on lower secondary pupils' interests in environment and nature protection]. Göttingen: Dr. Kovac.

Bixler, R. D., \& Floyd, M. F. (1997). Nature is scary, disgusting, and uncomfortable. Environment and Behavior, 29(4), 443-467. doi:10.1177/001391659702900401

Black, A. E., \& Deci, E. L. (2000). The effects of instructors' autonomy support and students' autonomous motivation on learning organic chemistry: A selfdetermination theory perspective. Science Education, 84, 740-756. 
Blair, D. (2009). The child in the garden: An evaluative review of the benefits of school gardening. The Journal of Environmental Education, 40(2), 15-38. doi:10.3200/JOEE.40.2.15-38

Bögeholz, S. (1999a). Muster der Naturerfahrung - Wege zu umweltgerechtem Handeln [Patterns of nature experience - Approaches to environmentally responsible behavior]. Mensch, Natur, Technik, 120-122.

Bögeholz, S. (1999b). Qualitäten primärer Naturerfahrung und ihr Zusammenhang mit Umweltwissen und Umwelthandeln [Qualitites of primary nature experience and its connection with environmental knowledge and environmental actions]. Opladen: Leske und Budrich.

Bögeholz, S. (2001). Naturerfahrungen auf Lern- und Schulbauernhöfen: Ihr Einfluss auf Umweltwissen und Umwelthandeln [Nature experience on educational and school farms: Its importance for environmental knowledge and action]. Überland, (1), 3-11.

Bögeholz, S. (2002). An empirical study of gender differences relevant to environmental education. In U. Pasero \& Gottburgsen (Eds.), Wie natürlich ist Geschlecht? Gender und die Konstruktion von Natur und Technik [How natural is gender? Gender and the construction of nature and technology] (pp. 215227). Wiesbaden: Westdeutscher Verlag.

Bögeholz, S. (2005). Lern- und Schulbauernhöfe und ihre Potentiale für Bildung für Nachhaltige Entwicklung [Educational and school farms and their potential for education for sustainable development]. Überland, (1), 3-9.

Bögeholz, S. (2006). Nature experience and its importance for environmental knowledge, values and action: Recent German empirical contributions. Environmental Education Research, 12(1), 65-84.

Bögeholz, S., Bittner, A., \& Knolle, F. (2006). Education in Harz national park - From nature experience to education for sustainable development. GAIA, 15(2), 135143.

Bogner, F. X. (1998). The influence of short-term outdoor ecology education on longterm variables of environmental perspective. The Journal of Environmental Education, 29(4), 17-29. doi:10.1080/00958969809599124

Bogner, F. X., \& Wiseman, M. (2004). Outdoor ecology education and pupils' environmental perception in preservation and utilization. Science Education International, 15(1), 27-48.

Bortz, J., \& Döring, N. (2006). Forschungsmethoden und Evaluation [Research methods and evaluation] (4. Aufl.). Heidelberg: Springer-Medizin-Verl. 
Bowd, A. D. (1982). Young children's beliefs about animals. Journal of Psychology, 110(2), 263-266.

Brämer, R. (2010). Natur: Vergessen? Erste Befunde des Jugendreports Natur 2010 [Nature: Forgotten? First results of the youth report nature 2010] (p. 20). Bonn: Deutscher Jagdschutz-Verband, information.medien.agrar e.V., Schutzgemeinschaft Deutscher Wald. Retrieved from http://www.wanderforschung.de/files/jrn10farbig1299054240.pdf

Browne, M. W., \& Cudeck, R. (1993). Alternative ways of assessing model fit. In K. A. Bollen \& J. S. Long (Eds.), Testing structural equation models (pp. 136-162). Newbury Park, Calif.: Sage.

Bundesministerium für Umwelt, Naturschutz und Reaktorsicherheit (BfN). (2010). Indikatorenbericht 2010 zur Nationalen Strategie zur biologischen Vielfalt [Indicator report 2010 on the national strategy regarding biological diversity ].

Cakmakci, G., Sevindik, H., Pektas, M., Uysal, A., Kole, F., \& Kavak, G. (2012). Investigating Turkish primary school students' interest in science by using their self-generated questions. Research in Science Education, 42(3), 469-489. doi:10.1007/s11165-010-9206-1

Carrier, S. J. (2009). Environmental education in the schoolyard: Learning styles and gender. The Journal of Environmental Education, 40(3), 2-12. doi:10.3200/JOEE.40.3.2-12

Carson, R. (1965). The sense of wonder. New York: Harper \& Row.

CBD. (1992). Convention on Biological Diversity. Bonn: Bundesgesetzblatt II.

Chawla, L., \& Cushing, D. F. (2007). Education for strategic environmental behavior. Environmental Education Research, 13(4), 437-452.

Chen, A. (1999). What constitutes situational interest? Validating a construct in physical education. Measurement in Physical Education and Exercise Science, 3(3), 157-180.

Chen, Q. (2012). The impact of ignoring a level of nesting structure in multilevel mixture model. Sage Open, 2(1), 1-10. doi:10.1177/2158244012442518

Cheng, J. C.-H., \& Monroe, M. C. (2012). Connection to nature: Children's affective attitude toward nature. Environment and Behavior, 44(1), 31-49. doi:10.1177/0013916510385082

Cochrane, W. (1981). The development of American agriculture: A historical analysis. Minneapolis: University of Minnesota Press. 
Corcoran, P. B., Osano, P. M., Weakland, J. P., \& Hollingshead, B. P. (2009). Young people, education, and sustainable development: Exploring principles, perspectives, and praxis. Wageningen: Wageningen Academic Publishers.

Deci, E. L. (1998). The relation of interest to motivation and human needs - The selfdetermination theory viewpoint. In Interest and learning - Proceedings of the Seeon Conference on Interest and Gender (pp. 146-163). Kiel: IPN.

Deci, E. L., Eghrari, H., Patrick, B. C., \& Leone, D. R. (1994). Facilitating Internalization: The Self-Determination Theory Perspective. Journal of Personality, 62(1), 119-142. doi:10.1111/j.1467-6494.1994.tb00797.x

Deci, E. L., \& Moller, A. C. (2005). The concept of competence: A starting place for understanding intrinsic motivation and self-determined extrinsic motivation. In A. Elliot \& C. S. Dweck (Eds.), The handbook of competence and motivation (pp. 579-597). New York, London: The Guildford Press.

Deci, E. L., \& Ryan, R., M. (1985). Intrinsic motivation and self-determination in human behaviour. New York: Plenum.

Deci, E. L., \& Ryan, R., M. (1993). Die Selbstbestimmungstheorie der Motivation und ihre Bedeutung für die Pädagogik. Zeitschrift Für Pädagogik, 39(2), 223-239.

Deci, E. L., \& Ryan, R., M. (2000). The "what" and "why" of goal pursuits: Human needs and the self-determination of behavior. Psychological Inquiry, 11(4), 227-268.

Deci, E. L., Ryan, R., M., Gagné, M., Leone, D. R., Usunov, J., \& Kornazheva, B. P. (2001). Need satisfaction, motivation, and well-being in the work organizations of a former eastern bloc country: A cross-cultural study of self-determination. Personality and Social Psycholgy Bulletin, 27(8), 930-942.

Deci, E. L., Vallerand, R. J., Pelletier, L. G., \& Ryan, R., M. (1991). Motivation and education: The self-determination perspective. Educational Psychologist, 26(3), 325-346.

Deci, E. L., \& Vansteenkiste, M. (2004). Self-determination theory and basic need satisfaction: Understanding human development in positive psychology. Ricerche Di Psichologia, 27(1), 23-40.

De Haan, G. (2006). The BLK "21" programme in Germany: A "Gestaltungskompetenz"-based model for Education for Sustainable Development. Environmental Education Research, 12(1), 19-32. doi:10.1080/13504620500526362

De Haan, G. (2010). The development of ESD-related competencies in supportive institutional frameworks. International Review of Education, 56(2-3), 315-328. 
De Haan, G., Kamp, G., Lerch, A., Martignon, L., Müller-Christ, G., \& Nutzinger, H.-G. (2008). Nachhaltigkeit und Gerechtigkeit: Grundlagen und schulpraktische Konsequenzen [Sustainability and justice: Foundations and practical consequences for school education]. Berlin: Springer.

Deutscher Bauernverband (DBV). (2011). Situationsbericht 2011/12 - Trends und Fakten zur Landwirtschaft [Status quo report 2011/12 - Trends and facts regarding agriculture]. Retrieved from http://www.situations-bericht.de

Deutscher Bauernverband (DBV). (2013). Situationsbericht 2013/14 - Trends und Fakten zur Landwirtschaft [Status quo report 2013/14 - Trends and facts regarding agriculture] (p. 306). Berlin. Retrieved from http://www.bauernverband.de/situationsbericht-2014

Dietze, J. (2007). Untersuchungen zum Entwicklungsstand von Biologieinteressen von Schülerinnen und Schülern der Sekundarstufe II [Investigation on the state of development of interests in biology of upper secondary school pupils]. Hamburg: Kovač.

Dillon, J., Rickinson, M., Sanders, D., \& Teamey, K. (2005). On food, farming and land management: Towards a research agenda to reconnect urban and rural lives. International Journal of Science Education, 27(11), 1359-1374. doi:10.1080/09500690500153865

Dillon, J., Rickinson, M., Teamey, K., Morris, M., Choi, M. Y., Sanders, D., \& Benefield, P. (2006). The value of outdoor learning: Evidence from research in the UK and elsewhere. School Science Review, 87(320), 107-111.

Diprete, T. A., \& Buchmann, C. (2006). Gender-specific trends in the value of education and the emerging gender gap in college completion. Demography, 43(1), 1-24. doi:10.1353/dem.2006.0003

Dochy, F., Segers, M., \& Buehl, M. M. (1999). The relation between assessment practices and outcomes of studies: The case of research on prior knowledge. Review of Educational Research, 69(2), 145-186. doi:10.2307/1170673

Dohn, N. B. (2011a). Situational interest of high school students who visit an aquarium. Science Education, 95(2), 337-357.

Dohn, N. B. (2011b). Upper secondary students' situational interest: A case study of the role of a zoo visit in a biology class. International Journal of Science Education, 47(0), 1-20. doi:10.1080/09500693.2011.628712

Dohn, N. B. (2013). Situational interest in engineering design activities. International Journal of Science Education, 35(12), 1-22. doi:10.1080/09500693.2012.757670 
Dräger, M., \& Vogt, H. (2007). Von Angst und Ekel zu Interesse [From fear and disgust towards interest]. Erkenntnisweg Biologiedidaktik, 6, 133-149.

Dreyfus, A. (1987). The potential role of agriculture in science teaching. Research in Rural Education, 4(1), 23-27.

Duckworth, A., \& Seligman, M. (2006). Self-discipline gives girls the edge: Gender in self-discipline, grades, and achievement test scores. Journal of Educational Psychology, 98(1), 198-208. doi:10.1037/0022-0663.98.1.198

Duisen, A. (2012). Nachbereitungen eines Schulbauernhofaufenthaltes im Biologieunterricht - Interesse wecken und aufrechterhalten [Curricular learning units in biology education following a school farm stay - Triggering and maintaining interest] (Master thesis). Departement of Biology Education, University of Göttingen, Göttingen, Germany.

Durik, A. M., \& Harackiewicz, J. M. (2007). Different strokes for different folks: How individual interest moderates the effects of situational factors on task interest. Journal of Educational Psychology, 99(3), 597-610.

Durlak, J., Weissberg, R., Dymnicki, A., Taylor, R., \& Schellinger, K. (2011). The impact of enhancing students' social and emotional learning: A meta-analysis of school-based universal interventions. Child Development, 82(1), 405-432. doi:10.1111/j.1467-8624.2010.01564.x

Eggert, S., \& Bögeholz, S. (2014). Entwicklung eines Testinstruments zur Messung von Schülerkompetenzen. In D. Krüger, I. Parchmann, \& H. Schecker (Eds.), Methoden in der naturwissenschaftsdidaktischen Forschung (pp. 371-384). Berlin, Heidelberg: Springer. Retrieved from http://link.springer.com/chapter/10.1007/978-3-642-37827-0_29

Eggert, S., Ostermeyer, F., Hasselhorn, M., \& Bögeholz, S. (2013). Socioscientific decision making in the science classroom: the effect of embedded metacognitive instructions on students' learning outcomes. Education Research International, 2013.

Ellenberg, H., \& Leuschner, C. (2010). Vegetation Mitteleuropas mit den Alpen: In ökologischer, dynamischer und historischer Sicht [The vegetation of central Europe and the Alps: From an ecological, dynamic, and historical point of view] (6. ed.). Stuttgart: Ulmer.

Field, A. P. (2013). Discovering statistics using IBM SPSS statistics: And sex and drugs and rock " $n$ " roll. Los Angeles: SAGE.

Finke, E. (1999). Faktoren der Entwicklung von Biologieinteressen in der Sekundarstufe I [Factors of the development of biology interests in lower secondary school]. In R. Duit \& J. Mayer (Eds.), Studien zur 
naturwissenschaftsdidaktischen Lern- und Interessenforschung (pp. 103-117). Kiel: Institut für die Pädagogik der Naturwissenschaften.

Flick, U. (Ed.). (2013). Qualitative Forschung: ein Handbuch (10th ed.). Reinbek: Rowohlt.

Food and Agriculture Organization of the United Nations (FAO). (2007). The State of the world's animal genetic resources for food and agriculture - in brief. Rome.

Freudenthaler, H. H., Spinath, B., \& Neubauer, A. C. (2008). Predicting school achievement in boys and girls. European Journal of Personality, 22(3), 231245. doi:10.1002/per.678

Frick, M., \& Kahler, A. (1991). A definition and the concepts of agricultural literacy. Journal of Agricultural Education, 32(2), 49-57. doi:10.5032/jae.1991.02049

Fröhlich, G., Goldschmidt, M., \& Bogner, F. X. (2013). The effect of age on students' conceptions of agriculture. Studies in Agricultural Economics, 115(2), 61-67.

Fröhlich, G., Sellmann, D., \& Bogner, F. X. (2012). The influence of situational emotions on the intention for sustainable consumer behaviour in a studentcentred intervention. Environmental Education Research, 19(6), 1-18. doi:10.1080/13504622.2012.749977

Furrer, C., \& Skinner, E. (2003). Sense of relatedness as a factor in children's academic engagement and performance. Journal of Educational Psychology, 95(1), 148-162. doi:10.1037/0022-0663.95.1.148

Gebhard, U. (2013). Kind und Natur: Die Bedeutung der Natur für die psychische Entwicklung [Child and nature: The importance of nature for mental development]. Wiesbaden: Springer.

Geiger, F., Bengtsson, J., Berendse, F., Weisser, W. W., Emmerson, M., Morales, M. B., ... Inchausti, P. (2010). Persistent negative effects of pesticides on biodiversity and biological control potential on European farmland. Basic and Applied Ecology, 11(2), 97-105. doi:16/j.baae.2009.12.001

Gläser-Zikuda, M., Seidel, T., Rohlfs, C., Gröschner, A., \& Ziegelbauer, S. (2012). Mixed Methods in der empirischen Bildungsforschung. Münster: Waxmann.

Gräber, W., Nentwig, P., Koballa, T., \& Evans, R. (Eds.). (2002). Scientific Literacy Der Beitrag der Naturwissenschaften zur allgemeinen Bildung [Scientific literacy - the contribution of science to general education]. Opladen: Leske und Budrich.

Graham, J. M. (2006). Congeneric and (essentially) tau-equivalent estimates of score reliability: What they are and how to use them. Educational and Psychological Measurement, 66(6), 930-944. doi:10.1177/0013164406288165 
Gräsel, C., \& Gruber, H. (2000). Kooperatives Lernen in der Schule. Theoretische Ansätze - Empirische Befunde - Desiderate für die Lehramtsausbildung. In N. Seibert (Ed.), Unterrichtsmethoden kontrovers (pp. 161-175). Bad Heilbrunn: Klinkhardt.

Grunert, K. G., Fernández-Celemín, L., Wills, J. M., Bonsmann, S., \& Nureeva, L. (2010). Use and understanding of nutrition information on food labels in six European countries. Journal of Public Health, 18(3), 261-277. doi:10.1007/s10389-009-0307-0

Guderian, P. (2007). Wirksamkeitsanalyse außerschulischer Lernorte [Effectiveness study of extracurricular places of learning] (Doctoral thesis). HumboldtUniversität zu Berlin, Mathematisch-Naturwissenschaftliche Fakultät I.

Gurian, M., \& Stevens, K. (2010). Boys and girls learn differently! A guide for teachers and parents. San Francisco: Jossey Bass.

Guthrie, J. T., Wigfield, A., Humenick, N. M., Perencevich, K. C., Taboada, A., \& Barbosa, P. (2006). Influences of Stimulating Tasks on Reading Motivation and Comprehension. The Journal of Educational Research, 99(4), 232-246. doi:10.3200/JOER.99.4.232-246

Hagay, G., Baram-Tsabari, A., Ametller, J., Cakmakci, G., Lopes, B., Moreira, A., \& Pedrosa-de-Jesus, H. (2013). The generalizability of students' interests in biology across gender, country and religion. Research in Science Education, 43(3), 895-919. doi:10.1007/s11165-012-9289-y

Haidt, J., McCauley, C., \& Rozin, P. (1994). Individual differences in sensitivity to disgust: A scale sampling seven domains of disgust elicitors. Personality and Individual Differences, 16(5), 701-713. doi:10.1016/0191-8869(94)90212-7

Harackiewicz, J. M., Durik, A. M., Barron, K. E., Linnenbrink-Garcia, L., \& Tauer, J. M. (2008). The role of achievement goals in the development of interest: Reciprocal relations between achievement goals, interest, and performance. Journal of Educational Psychology, 100(1), 105-122. doi:10.1037/00220663.100.1.105

Haubenhofer, D., Hassink, J., van der Meer, I., van de Kamp, N., Schreurs, E., \& Schuler, Y. (2010). Farm education in the Netherlands. In Building sustainable rural futures. The added value of systems approaches in times of change and uncertainty (pp. 1955-1962). Vienna (Austria). Retrieved from http://ifsa.boku.ac.at/cms/fileadmin/Proceeding2010/2010_WS4.5_Haubenhofer .pdf 
Henkel, G. (2012). Das Dorf: Landleben in Deutschland gestern und heute [The village: Rural living in Germany in past and present]. Stuttgart: Konrad Theiss Verlag $\mathrm{GmbH}$.

Hidi, S. (1990). Interest and its contribution as a mental resource for learning. Review of Educational Research, 60(4), 549-571.

Hidi, S. (2000). An interest researcher's perspective: The effects of extrinsic and intrinsic factors on motivation. In C. Sansone \& J. M. Harackiewicz (Eds.), Intrinsic and extrinsic motivation: The search for optimal motivation and performance (pp. 309-339). San Diego: Academic Press.

Hidi, S., \& Baird, W. (1986). Interestingness - A neglected variable in discourse processing. Cognitive Science, 10(2), 179-194. doi:10.1207/s15516709cog1002_3

Hidi, S., \& Baird, W. (1988). Strategies for increasing text-based interest and students' recall of expository texts. Reading Research Quarterly, 23(4), 465-483. doi: $10.2307 / 747644$

Hidi, S., \& Renninger, K. A. (2006). The four-phase model of interest development. Educational Psychologist, 41(2), 111-127. doi:10.1207/s15326985ep4102_4

Hidi, S., Renninger, K. A., \& Krapp, A. (2004). Interest, a motivational variable that combines affective and cognitive functioning. In D. Y. Dai (Ed.), Motivation. emotion and cognition: Integrative perspectives on intellectual functioning and development (pp. 89-115). Mahwah N.J.: Erlbaum.

Holstermann, N., Ainley, M., Grube, D., Roick, T., \& Bögeholz, S. (2012). The specific relationship between disgust and interest: Relevance during biology class dissections and gender differences. Learning and Instruction, 22(3), 185-192. doi:10.1016/j.learninstruc.2011.10.005

Holstermann, N., \& Bögeholz, S. (2007). Interesse von Jungen und Mädchen an naturwissenschaftlichen Themen am Ende der Sekundarstufe I [Interest of boys and girls in science topics at the end of lower secondary school]. Zeitschrift Für Didaktik Der Naturwissenschaften, 13, 71-86.

Holstermann, N., Grube, D., \& Bögeholz, S. (2010). Hands-on activities and their influence on students' interest. Research in Science Education, 40(5), 743-757. doi:10.1007/s11165-009-9142-0

Hopkins, C., \& McKeown, R. (2002). Education for sustainable development: An international perspective. In D. Tilbury, R. Stevenson, J. Fien, \& D. Schreuder (Eds.), Education and sustainability: Responding to the global challenge (pp. 13-24). Gland, Switzerland and Cambridge, UK: Commission on Education and 
Communication, IUCN. Retrieved from

http://www.academia.edu/download/30919504/education.pdf\#page=25

Hubert, D., Frank, A., \& Igo, C. (2000). Environmental and agricultural literacy education. Water, Air, and Soil Pollution, 123(1-4), 525-532. doi:10.1023/A:1005260816483

Hübner, S. (2000). Voll im Trend - der Schulbauernhof [The school farm in vogue]. Ökologie \& Landbau, 2, 6-8.

Hulleman, C. S., Godes, O., Hendricks, B. L., \& Harackiewicz, J. M. (2010). Enhancing interest and performance with a utility value intervention. Journal of Educational Psychology, 102(4), 880-895. doi:10.1037/a0019506

Hummel, E., Glück, M., Jürgens, R., Weisshaar, J., \& Randler, C. (2012). Interesse, Wohlbefinden und Langeweile im naturwissenschaftlichen Unterricht mit lebenden Organismen [Interest, well-being, and boredem in science lessons with living organisms]. Zeitschrift Für Didaktik Der Naturwissenschaften, 18, 99116.

Institut für ökologische Wirtschaftsforschung (IÖW), Öko-Institut e.V., SchweisfurthStiftung, Freie Universität Berlin, \& Landesanstalt für Großschutzgebiete. (2004). Agrobiodiversität entwickeln! Handlungsstrategien für eine nachhaltige Tier- und Pflanzenzucht [Developing agrobiodiversity! Strategies of action towards sustainable animal and plant breeding]. Berlin.

Izard, C. E. (1977). Human emotions. New York: Plenum Press.

Jenkins, E. W., \& Pell, R. G. (2006). The relevance of science education project (ROSE) in England: A summary of findings. Leeds: Centre for Studies in Science and Mathematics Education, University of Leeds.

Jidesjö, A. (2008). Different content orientations in science and technology among primary and secondary boys and girls in Sweden: Implications for the transition from primary to secondary school? Nordic Studies in Science Education, 4(2), 192-208.

Jones, M. G., Howe, A., \& Rua, M. J. (2000). Gender differences in students' experiences, interests, and attitudes toward science and scientists. Science Education, 84(2), 180-192. doi:10.1002/(SICI)1098237X(200003)84:2<180::AID-SCE3>3.0.CO;2-X

Jöreskog, K. G., \& Sörbom, D. (1996). LISREL 8 user's reference guide. Chicago: Scientific Software International.

Joshi, A., Azuma, A. M., \& Feenstra, G. (2008). Do Farm-to-School programs make a difference? Findings and future research needs. Journal of Hunger \& Environmental Nutrition, 3(2-3), 229-246. doi:10.1080/19320240802244025 
Kals, E., Schumacher, D., \& Montada, L. (1999). Emotional affinity toward nature as a motivational basis to protect nature. Environment and Behavior, 31(2), 178202. doi:10.1177/00139169921972056

Katz, I., \& Assor, A. (2007). When choice motivates and when it does not. Educational Psychology Review, 19(4), 429-442.

Kier, M. W., Blanchard, M. R., Osborne, J. W., \& Albert, J. L. (2013). The Development of the STEM Career Interest Survey (STEM-CIS). Research in Science Education, 44(3), 461-481. doi:10.1007/s11165-013-9389-3

King, K., \& Gurian, M. (2006). Teaching to the Minds of Boys. Educational Leadership, 64(1), 56-61.

Klahr, D., Triona, L. M., \& Williams, C. (2007). Hands on what? The relative effectiveness of physical versus virtual materials in an engineering design project by middle school children. Journal of Research in Science Teaching, 44(1), 183-203. doi:10.1002/tea.20152

KMK. (2004). Bildungsstandards im Fach Biologie für den Mittleren Schulabschluss [Educational standards for biology in lower secondary school]. Luchterhand.

Knauss, J. (Ed.). (1998). Technisierung des ländlichen Raumes: Landtechnik und technische Anlagen im Freilichtmuseum [Meachanization of rural areas: Agricultural machinery and technological facilities in the open air museum]. Blankenhain: Schloss Blankenhain, Agrar- und Freilichtmuseum.

Knobloch, N., Ball, A., \& Allen, C. (2007). The benefits of teaching and learning about agriculture in elementary and junior high schools. Journal of Agricultural Education, 48(3), 25-36. doi:10.5032/jae.2007.03025

Köller, O., Baumert, J., \& Schnabel, K. (2001). Does interest matter? The relationship between academic interest and achievement in mathematics. Journal for Research in Mathematics Education, 32(5), 448-470.

Köller, O., Trautwein, U., Lüdtke, O., \& Baumert, J. (2006). Zum Zusammenspiel von schulischer Leistung, Selbstkonzept und Interesse in der gymnasialen Oberstufe [On the interplay of academic achievement, self-concept, and interest in upper secondary school ]. Zeitschrift Für Pädagogische Psychologie, 20(1), 27-39. doi:10.1024/1010-0652.20.12.27

Krapp, A. (1998). Entwicklung und Förderung von Interessen im Unterricht [Development and promotion of interest in instruction]. Psychologie in Erziehung Und Unterricht, 44(3), 185-201. 
Krapp, A. (1999). Interest, motivation and learning: An educational-psychological perspective. European Journal of Psychology of Education, 14(1), 23-40. doi:10.1007/BF03173109

Krapp, A. (2002a). An educational-psychological theory of interest and its relation to SDT. In E. L. Deci \& R. M. Ryan (Eds.), Handbook of self-determination research (pp. 405-427). Rochester NY: University of Rochester Press.

Krapp, A. (2002b). Structural and dynamic aspects of interest development: Theoretical considerations from an ontogenetic perspective. Learning and Instruction, 12(4), 383-409. doi:16/S0959-4752(01)00011-1

Krapp, A. (2003). Interest and human development: An educational-psychological perspective. BJEP Monograph Series II, 2, 57-84.

Krapp, A. (2005). Basic needs and the development of interest and intrinsic motivational orientations. Learning and Instruction, 15(5), 381-395. doi:16/j.learninstruc.2005.07.007

Krapp, A. (2007). An educational-psychological conceptualisation of interest. International Journal for Educational and Vocational Guidance, 7(1), 5-21. doi:10.1007/s10775-007-9113-9

Krapp, A., \& Prenzel, M. (Eds.). (1992). Interesse, Lernen, Leistung - Neuere Ansätze der pädagogisch-psychologischen Interessenforschung [Interest, learning, achievement - new approaches of pedagogic-psychological interest research]. Münster: Aschendorff.

Krapp, A., \& Prenzel, M. (2011). Research on interest in science: Theories, methods, and findings. International Journal of Science Education, 33(1), 27-50. doi:10.1080/09500693.2010.518645

Krogh, E., \& Jolly, L. (2011). Making sense of place: School-farm cooperation in Norway. Children Youth and Environments, 21(1), 310-321.

Krogh, E., \& Jolly, L. (2012). Relationship-based experiential learning in practical outdoor tasks. In A. E. J. Wals \& P. B. Corcoran (Eds.), Learning for sustainability in times of accelerating change (pp. 213-224). Wageningen Academic Publishers. Retrieved from http://www.wageningenacademic.com/learn4-e_13

Kuhlemeier, H., van Den Bergh, H., \& Lagerweij, N. (1999). Environmental knowledge, attitudes, and behavior in Dutch secondary education. The Journal of Environmental Education, 30(2), 4-14. doi:10.1080/00958969909601864

Kunter, M., Baumert, J., \& Köller, O. (2007). Effective classroom management and the development of subject-related interest. Learning and Instruction, 17(5), 494509. doi:10.1016/j.learninstruc.2007.09.002 
Laukenmann, M., Bleicher, M., Fuß, S., Gläser-Zikuda, M., Mayring, P., \& von Rhöneck, C. (2003). An investigation of the influence of emotional factors on learning in physics instruction. International Journal of Science Education, 25(4), 489-507. doi:10.1080/09500690210163233

Legewie, J., \& DiPrete, T. A. (2009). Family determinants of the changing gender gap in educational attainment: A comparison of the US and Germany. Schmollers Jahrbuch - Journal of Applied Social Science Studies, 129(2), 1-13.

Leigh, G. J. (2004). The world's greatest fix: A history of nitrogen and agriculture. Oxford Univ. Press.

Lekies, K. S., \& Sheavly, M. E. (2007). Fostering children's interests in gardening. Applied Environmental Education \& Communication, 6(1), 67-75. doi:10.1080/15330150701319362

Leske, S., \& Bögeholz, S. (2008). Biologische Vielfalt regional und weltweit erhalten Zur Bedeutung von Naturerfahrung, Interesse an der Natur, Bewusstsein über deren Gefährdung und Verantwortung [Impact of nature experiences, interest in nature, awareness of endangered biodiversity and responsibility on global and local biodiversity conservation]. Zeitschrift Für Didaktik Der Naturwissenschaften, 14, 167-184.

Lewalter, D., \& Geyer, C. (2009). Motivationale Aspekte von schulischen Besuchen in naturwissenschaftlich-technischen Museen [Motivational aspects of school visits to natural science and technical museums]. Zeitschrift Für Erziehungswissenschaft, 12(1), 28-44.

Lewalter, D., \& Willems, A. S. (2009). Die Bedeutung des motivationsrelevanten Erlebens und des individuellen Fachinteresses für das situationale Interesse im Mathematikunterricht [The relevance of emotional experiences and subjectrelated interest for situational interest in mathematics]. Psychologie in Erziehung Und Unterricht, 56(4), 243-257.

Liefländer, A. K., Fröhlich, G., Bogner, F. X., \& Schultz, P. W. (2013). Promoting connectedness with nature through environmental education. Environmental Education Research, 19(3), 1-15. doi:10.1080/13504622.2012.697545

Liess, M., Brown, C., Dohmen, P., Duquesne, S., Heimbach, F., Kreuger, J., ... Tarazona, J. V. (2005). Effects of pesticides in the field. Brüssel: Society of Environmental Toxicology and Chemistry (SETAC).

Lindemann-Matthies, P. (2005). "Loveable" mammals and "lifeless" plants: How children's interest in common local organisms can be enhanced through observation of nature. International Journal of Science Education, 27(6), 655677. 
Linnenbrink-Garcia, L., Durik, A. M., Conley, A. M., Barron, K. E., Tauer, J. M., Karabenick, S. A., \& Harackiewicz, J. M. (2010). Measuring situational interest in academic domains. Educational and Psychological Measurement, 70(4), 647-671. doi:10.1177/0013164409355699

Lipstein, R. L., \& Renninger, K. A. (2007). "Putting things into words": The development of 12-15-year-old students' interest for writing. In P. Boscolo \& S. Hidi (Eds.), Motivation and writing: Research and school practice (Vol. 19, pp. 113-140). New York: Kluwer Academic/Plenum.

Liu, C. (2004). Multi-item measures. In M. Lewis-Beck, A. Bryman, \& T. F. Liao (Eds.), Encyclopedia of social science research methods (p. 674). Thousans Oaks, CA: SAGE Publications, Inc.

Loo, R. (2002). A caveat on using single-item versus multiple-item scales. Journal of Managerial Psychology, 17(1), 68-75. doi:10.1108/02683940210415933

Löwe, B. (1987). Interessenverfall im Biologieunterricht. Ergebnisse empirischer Forschung [Interest decline in biology education: Results of empirical research]. Unterricht Biologie, 11(124), 62-65.

Löwe, B. (1992). Biologieunterricht und Schülerinteresse an Biologie [Biology instruction and pupils' interest in biology]. Weinheim: Dt. Studien-Verl.

Maas, C. J., \& Hox, J. J. (2005). Sufficient sample sizes for multilevel modeling. Methodology, 1(3), 86-92. doi:10.1027/1614-1881.1.3.86

Mabie, R., \& Baker, M. (1996). The influence of experiential instruction on urban elementary students' knowledge of the food and fiber system. Journal of Extension, 34(6), 1-4.

Magner, U. I. E., Schwonke, R., Aleven, V., Popescu, O., \& Renkl, A. (2014).

Triggering situational interest by decorative illustrations both fosters and hinders learning in computer-based learning environments. Learning and Instruction, 29, 141-152. doi:10.1016/j.learninstruc.2012.07.002

Maguire, S. (1998). Gender differences in attitudes to undergraduate fieldwork. Area, 30(3), 207-214. doi:10.1111/j.1475-4762.1998.tb00065.x

Malina, R. M., Bouchard, C., \& Bar-Or, O. (2004). Growth, maturation, and physical activity. Champaign: Human Kinetics.

Matthews, J. S., Ponitz, C. C., \& Morrison, F. (2009). Early gender differences in selfregulation and academic achievement. Journal of Educational Psychology, 101(3), 689-704. doi:10.1037/a0014240 
Matz, S. (2008). Landwirtschaft erleben: zur Vermittlung agrarischer Umweltbildungsinhalte [Experiencing agriculture: About teaching agricultural content in environmental education]. München: oekom.

Mazoyer, M., \& Roudart, L. (2006). A history of world agriculture: From the neolithic age to the current crisis. New York: Monthly Review Pr.

McComas, W. F. (2014). Outdoor Science Education. In W. F. McComas (Ed.), The Language of Science Education (p. 70). Rotterdam, Boston, Taipei:

SensePublishers. Retrieved from http://link.springer.com/chapter/10.1007/97894-6209-497-0_60

Meinzen-Dick, R., Behrman, J., Menon, P., \& Quisumbing, A. (2012). Gender: A key dimension linking agricultural programs to improved nutrition and health. In S. Fan \& R. Pandya-Lorch (Eds.), Reshaping agriculture for nutrition and health (pp. 135-144). Washington DC: International Food Policy Research Institute.

Menzel, S., \& Bögeholz, S. (2009). The loss of biodiversity as a challenge for sustainable development: How do pupils in Chile and Germany perceive resource dilemmas? Research in Science Education, 39(4), 429-447. doi:10.1007/s11165-008-9087-8

Millennium Ecosystem Assessment (MEA). (2005). Ecosystems and human well-being: Biodiversity synthesis. Washington, DC: World Resources Institute.

Minnaert, A., Boekaerts, M., \& de Brabander, C. (2007). Autonomy, competence, and social relatedness in task interest within project-based education. Psychological Reports, 101(2), 574-586. doi:10.2466/pr0.101.2.574-586

Mitchell, M. (1993). Situational interest: Its multifaceted structure in the secondary school mathematics classroom. Journal of Educational Psychology, 85(3), 424436. doi:10.1037/0022-0663.85.3.424

Morag, O., Tal, T., \& Rotem-Keren, T. (2013). Long-term educational programs in nature parks: Characteristics, outcomes and challenges. International Journal of Environmental and Science Education, 8, 427-449.

Nellemann, C., \& Corcoran, E. (2010). Dead planet, living planet: Biodiversity and ecosystem restoration for sustainable development: $A$ rapid response assessment. UNEP/Earthprint. Retrieved from http://books.google.de/books?hl=de\&lr=\&id=irLBX3nBEQC\&oi=fnd\&pg=PA11\&dq=Nellemann+\%26+Corcoran+2010\&ots=VY9fg 4 $\mathrm{BHzo \& sig=XcbCjGjoui-YsxYNyKOwE1jBRbU}$

Neubauer, K., Geyer, C., \& Lewalter, D. (2014). Bedeutung der basic needs für das situationale Interesse bei Museumsbesuchen mit unterschiedlichen Instruktionsdesigns [The relevance of basic needs for situational interest in 
museum visits with different instructional designs]. Psychologie in Erziehung Und Unterricht, 61(1), 28-41. doi:10.2378/peu2014.art04d

Osborne, J., Simon, S., \& Collins, S. (2003). Attitudes towards science: A review of the literature and its implications. International Journal of Science Education, 25(9), 1049-1079. doi:10.1080/0950069032000032199

Oshagbemi, T. (1999). Overall job satisfaction: How good are single versus multipleitem measures? Journal of Managerial Psychology, 14(5), 388-403. doi:10.1108/02683949910277148

Özden, M. (2008). Environmental awareness and attitudes of student teachers: An empirical research. International Research in Geographical and Environmental Education, 17(1), 40-55. doi:10.2167/irgee227.0

Paas, F., Tuovinen, J. E., Merriënboer, J. J. G. van, \& Darabi, A. A. (2005). A motivational perspective on the relation between mental effort and performance: Optimizing learner involvement in instruction. Educational Technology Research and Development, 53(3), 25-34. doi:10.1007/BF02504795

Pachauri, R. K., \& Reisinger, A. (2007). Climate change 2007: Synthesis report. Contribution of working Groups I, II and III to the fourth assessment report of the intergovernmental panel on climate change (p. 104). Geneva, Switzerland: IPCC.

Palmer, D. (2004). Situational interest and the attitudes towards science of primary teacher education students. International Journal of Science Education, 26(7), 895-908. doi:10.1080/0950069032000177262

Palmer, D. (2009). Student interest generated during an inquiry skills lesson. Journal of Research in Science Teaching, 46(2), 147-165. doi:10.1002/tea.20263

Pekrun, R. (1988). Emotion, Motivation und Persönlichkeit [Emotion, motivation, and personality]. München: Psychologie-Verl.-Union.

Poudel, D., Vincent, L. M., Anzalone, C., Huner, J., Wollard, D., Clement, T., ... Blakewood, G. (2005). Hands-On activities and challenge tests in agricultural and environmental education. The Journal of Environmental Education, 36(4), 10-22.

Prenzel, M. (1998). Interest research concerning the upper secondary level, college, and vocational education: An overview. In L. Hoffmann, A. Krapp, K. A. Renninger, \& J. Baumert (Eds.), Proceedings of the Seeon Conference on interest and gender (pp. 355-366). Kiel: IPN.

Prenzel, M., Krapp, A., \& Schiefele, U. (1986). Grundzüge einer pädagogischen Interessenstheorie [Features of an educational theory of interest]. Zeitschrift Für Pädagogik, 32, 163-173. 
Prokop, P., Tuncer, G., \& Chudá, J. (2007). Slovakian students' attitudes toward biology. Eurasia Journal of Mathematics, Science \& Technology Education, 3(4), 287-295.

Prokop, P., \& Tunnicliffe, S. D. (2010). Effects of having pets at home on children's attitudes toward popular and unpopular animals. Anthrozoos: A Multidisciplinary Journal of The Interactions of People \& Animals, 23(1), 21-35. doi:10.2752/175303710X12627079939107

Ramankutty, N., Foley, J. A., \& Olejniczak, N. J. (2002). People on the land: Changes in global population and croplands during the 20th century. AMBIO: A Journal of the Human Environment, 31(3), 251-257. doi:10.1579/0044-7447-31.3.251

Randler, C., \& Bogner, F. X. (2007). Pupils' interest before, during, and after a curriculum dealing with ecological topics and its relationship with achievement. Educational Research and Evaluation, 13(5), 463-478. doi:10.1080/13803610701728295

Randler, C., Khambari, M. N., Moses, P., Luan, W. S., \& Simsek, A. (2009). Association between emotional variables and school achievement. International Journal of Instruction, 2(2), 3-10.

Ratcliffe, M. M., Merrigan, K. A., Rogers, B. L., \& Goldberg, J. P. (2011). The effects of school garden experiences on middle school-aged students' knowledge, attitudes, and behaviors associated with vegetable consumption. Health Promotion Practice, 12(1), 36-43. doi:10.1177/1524839909349182

Reinmann, G., \& Mandl, H. (2006). Unterrichten und Lernumgebungen gestalten. In A. Krapp \& B. Weidenmann (Eds.), Pädagogische Psychologie (pp. 613-658). Weinheim: Beltz.

Renninger, K. A. (2000). Individual interest and its implications for understanding intrinsic motivation. In C. Sansone \& J. M. Harackiewicz (Eds.), Intrinsic and extrinsic motivation: The search for optimal motivation and performance (pp. 373-404). San Diego: Academic Press.

Renninger, K. A. (2009). Interest and identity development in instruction: An inductive model. Educational Psychologist, 44(2), 105-118.

Renninger, K. A., Ewen, L., \& Lasher, A. K. (2002). Individual interest as context in expository text and mathematical word problems. Learning and Instruction, 12(4), 467-490. doi:10.1016/S0959-4752(01)00012-3

Renninger, K. A., \& Hidi, S. (2002). Student interest and achievement: Developmental issues raised by a case study. In A. Wigfield \& J. S. Eccles (Eds.), Development of achievement motivation (pp. 173-195). New York: Academic Press. 
Renninger, K. A., \& Hidi, S. (2011). Revisiting the conceptualization, measurement, and generation of interest. Educational Psychologist, 46(3), 168-184. doi:10.1080/00461520.2011.587723

Renting, H., Rossing, W. A. H., Groot, J. C. J., Van der Ploeg, J. D., Laurent, C., Perraud, D., ... Van Ittersum, M. K. (2009). Exploring multifunctional agriculture. A review of conceptual approaches and prospects for an integrative transitional framework. Journal of Environmental Management, 90, Supplement 2, 112 123. doi:10.1016/j.jenvman.2008.11.014

Robinson, R. A., \& Sutherland, W. J. (2002). Post-war changes in arable farming and biodiversity in Great Britain. Journal of Applied Ecology, 39(1), 157-176. doi:10.1046/j.1365-2664.2002.00695.x

Rockström, J., Steffen, W., Noone, K., Persson, A., Chapin, F. S., Lambin, E. F., ... Foley, J. A. (2009). A safe operating space for humanity. Nature, 461(7263), 472-475. doi:10.1038/461472a

Rotgans, J. I., \& Schmidt, H. G. (2011a). Situational interest and academic achievement in the active-learning classroom. Learning and Instruction, 21(1), 58-67. doi:16/j.learninstruc.2009.11.001

Rotgans, J. I., \& Schmidt, H. G. (2011b). The role of teachers in facilitating situational interest in an active-learning classroom. Teaching and Teacher Education, 27(1), 37-42. doi:10.1016/j.tate.2010.06.025

Rotgans, J. I., \& Schmidt, H. G. (2014). Situational interest and learning: Thirst for knowledge. Learning and Instruction, 32, 37-50. doi:10.1016/j.learninstruc.2014.01.002

Rubenstein, J. (2010). The cultural landscape: An introduction to human geography (10. ed.). Miami: Prentice Hall.

Ryan, R. M., \& Deci, E. L. (2000). Self-determination theory and the facilitation of intrinsic motivation, social development, and well-being. American Psychologist, 55(1), 68-78.

Sala, O. E., Chapin, F. S., Armesto, J. J., Berlow, E., Bloomfield, J., Dirzo, R., ... Wall, D. H. (2000). Global biodiversity scenarios for the year 2100. Science, 287(5459), 1770-1774. doi:10.1126/science.287.5459.1770

Sansone, C., \& Thoman, D. B. (2005). Does what we feel affect what we learn? Some answers and new questions. Learning and Instruction, 15(5), 507-515. doi:10.1016/j.learninstruc.2005.07.015

Scharfenberg, F.-J. (2005). Experimenteller Biologieunterricht zu Aspekten der Gentechnik im Lernort Labor: empirische Untersuchung zu Akzeptanz, Wissenserwerb und Interesse [Experimental biology instruction on aspects of 
genetic engineering in the laboratory: Empirical investigation on acceptance, knowledge acquisition, and interest] (Doctoral thesis). Faculty of Biology Education, University of Bayreuth, Bayreuth.

Scharfenberg, F.-J., \& Bogner, F. X. (2013). Teaching gene technology in an outreach lab: Students' assigned cognitive load clusters and the clusters' relationships to learner characteristics, laboratory variables, and cognitive achievement. Research in Science Education, 43(1), 141-161. doi:10.1007/s11165-0119251-4

Schiefele, U. (1990a). The influence of topic interest, prior knowledge, and cognitive capabilities on text comprehension. In J. Pieters, K. Breuer, \& P. R. Simons (Eds.), Learning environments (pp. 323-338). Berlin: Springer.

Schiefele, U. (1990b). Thematisches Interesse, Variablen des Lernprozesses und Textverstehen [Topic interest, variables of the learning process, and text comprehension]. Zeitschrift Für Experimentelle Und Angewandte Psychologie, 37(2), 304-332.

Schiefele, U. (1991). Interest, learning, and motivation. Educational Psychologist, 26(3), 299-323.

Schiefele, U. (1992). Topic interest and levels of text comprehension. In K. A. Renninger, S. Hidi, \& A. Krapp (Eds.), The role of interest in learning and development (pp. 151-182). Hillsdale N.J.: Erlbaum.

Schiefele, U. (1996a). Motivation und Lernen mit Texten [Motivation and learning with texts]. Göttingen: Hogrefe.

Schiefele, U. (1996b). Topic interest, text representation, and quality of experience. Contemporary Educational Psychology, 21(1), 3-18. doi:10.1006/ceps.1996.0002

Schiefele, U. (2009). Situational and individual interest. In K. R. Wentzel \& A. Wigfield (Eds.), Handbook of motivation at school (pp. 197-222). New York: Taylor \& Francis.

Schiefele, U., \& Krapp, A. (1996). Topic interest and free recall of expository text. Learning and Individual Differences, 8(2), 141-160. doi:16/S10416080(96)90030-8

Schiefele, U., Krapp, A., Wild, K. P., \& Winteler, A. (1992). Eine neue Version des "Fragebogens zum Studieninteresse" (FSI) [A new version of the questionnaire of study interest]. Gelbe Reihe-Arbeiten Zur Empirischen Pädagogik Und Pädagogischen Psychologie, 21, 1-28.

Schiefele, U., Krapp, A., \& Winteler, A. (2014). Interest as predictor of academic achievement: A meta-analysis fo research. In A. Renninger, S. Hidi, \& A. Krapp 
(Eds.), The role of interest in learning and development (pp. 183-212). New York: Psychology Press.

Schienle, A., Walter, B., Stark, R., \& Vaitl, D. (2002). Ein Fragebogen zur Erfassung der Ekelempfindlichkeit (FEE) [A questionnaire to assess disgust sensitivity]. Zeitschrift Für Klinische Psychologie Und Psychotherapie, 31(2), 110-120. doi:10.1026//1616-3443.31.2.110

Schockemöhle, J. (2009). Außerschulisches regionales Lernen als Bildungsstrategie für eine nachhaltige Entwicklung: Entwicklung und Evaluierung des Konzeptes "Regionales Lernen 21+" [Extracurricular regional learning as educational strategy for a sustainable development: Development and evaluation of the concept "Regional learning 21+"]. Weingarten: Hochschulverband für Geographie.

Schockemöhle, J. (2011). Academic foundation of learning on farms. Vechta: Competence Centre of Regional Learning , University of Vechta.

Schockemöhle, J. (2012). Lernen auf dem Bauernhof - was steckt dahinter? [Learning on a farm - what's behind?]. B\&B Agrar, 65(1), 9-11.

Schraw, G., Bruning, R., \& Svoboda, C. (1995). Sources of situational interest. Journal of Reading Behavior, 27(1), 1-17.

Schreiner, C. (2006). Exploring a ROSE-Garden. Norwegian youth's orientations towards science - Seen as signs of late modern identities (Doctoral thesis). Faculty of Education, University of Oslo, Oslo.

Schweizer, K. (2010). Improving the interpretability of the variances of latent variables by uniform and factor-specific standardizations of loadings. Methodology: European Journal of Research Methods for the Behavioral and Social Sciences, 6(4), 152-159. doi:10.1027/1614-2241/a000017

Schweizer, K., Altmeyer, M., Reiß, S., \& Schreiner, M. (2010). The c-bifactor model as a tool for the construction of semi-homogeneous upper-level measures. Psychological Test and Assessment Modeling, 52, 298-312.

Seidl, A. (2006). Deutsche Agrargeschichte [German history of agriculture] (2. Aufl.). Frankfurt am Main: DLG-Verl.

Sharma, S. (1996). Applied multivariate techniques. New York: John Wiley \& Sons.

Silvia, P. J. (2005a). Cognitive appraisals and interest in visual art: Exploring an appraisal theory of aesthetic emotions. Empirical Studies of the Arts, 23(2), 119-133. doi:10.2190/12AV-AH2P-MCEH-289E

Silvia, P. J. (2005b). What is interesting? Exploring the appraisal structure of interest. Emotion, 5(1), 89-102. doi:10.1037/1528-3542.5.1.89 
Silvia, P. J. (2006). Exploring the psychology of interest. Oxford; New York: Oxford University Press.

Silvia, P. J. (2010). Confusion and interest: The role of knowledge emotions in aesthetic experience. Psychology of Aesthetics, Creativity, and the Arts, 4(2), 75-80. doi:10.1037/a0017081

Skinner, E. A., \& Chi, U. (2012). Intrinsic motivation and engagement as "active ingredients" in garden-based education: Examining models and measures derived from Self-Determination Theory. The Journal of Environmental Education, 43(1), 16-36. doi:10.1080/00958964.2011.596856

Smeds, P., Jeronen, E., Kurppa, S., \& Vieraankivi, M.-L. (2011). Rural camp school eco learn - Outdoor education in rural settings. International Journal of Environmental and Science Education, 6(3), 267-291.

Smil, V. (2004). Enriching the earth: Fritz Haber, Carl Bosch, and the transformation of world food production. Cambridge: MIT Press.

Spörhase-Eichmann, U., \& Ruppert, W. (Eds.). (2004). Biologie-Didaktik: Praxishandbuch für die Sekundarstufe I und II [Biology education: Manual for lower and upper secondary school]. Berlin: Cornelsen Scriptor.

Ständige Konferenz der Kultusminister der Länder in der Bundesrepublik Deutschland (KMK) (Ed.). (2005). Bildungsstandards im Fach Biologie für den Mittleren Schulabschluss [Educational standards in biology for lower secondary school]. München: Wolters Kluwer.

Statistisches Bundesamt. (2011). Erwerbstätige im Inland nach Wirtschaftssektoren in Deutschland [Employees according to economic sectors in Germany]. http://www.destatis.de/jetspeed/portal/cms/Sites/destatis/Internet/DE/Co ntent/Statistiken/Zeitreihen/LangeReihen/Arbeitsmarkt/Content75/Irerw13a ,templateld=renderPrint.psml.

Stern, M. J., Powell, R. B., \& Ardoin, N. M. (2008). What difference does it make? Assessing outcomes from participation in a residential environmental education program. The Journal of Environmental Education, 39(4), 31-43. doi:10.3200/JOEE.39.4.31-43

Swarat, S., Ortony, A., \& Revelle, W. (2012). Activity matters: Understanding student interest in school science. Journal of Research in Science Teaching, 49(4), 515-537. doi:10.1002/tea.21010

Tal, T. (2008). Learning about agriculture within the framework of education for sustainability. Environmental Education Research, 14(3), 273-290. 
Tilman, D., Fargione, J., Wolff, B., D’Antonio, C., Dobson, A., Howarth, R., ... Swackhamer, D. (2001). Forecasting agriculturally driven global environmental change. Science, 292(5515), 281-284. doi:10.1126/science.1057544

TNS Emnid. (2012). Das Image der deutschen Landwirtschaft: Ergebnisse einer Repräsentativbefragung in Deutschland [The image of the German agriculture: Results of a representative survey in Germany] (p. 37). information.medien.agrar e.V. Retrieved from http://media.repromayr.de/34/544134.pdf

Tobias, S. (1994). Interest, prior knowledge, and learning. Review of Educational Research, 64(1), 37-54. doi:10.3102/00346543064001037

Trexler, C. J. (2000a). A qualitative study of urban and suburban elementary student understandings of pest-related science and agricultural education benchmarks. Journal of Agricultural Education, 41(3), 89-102.

Trexler, C. J. (2000b). Elementary and middle school teacher ideas about the agri-food system and their evaluation of agri-system stakeholders' suggestions for education. Journal of Agricultural Education, 41(1), 30-38. doi:10.5032/jae.2000.01030

Tsai, Y.-M., Kunter, M., Lüdtke, O., Trautwein, U., \& Ryan, R. M. (2008). What makes lessons interesting? The role of situational and individual factors in three school subjects. Journal of Educational Psychology, 100(2), 460-472. doi:10.1037/0022-0663.100.2.460

United Nations. (1992). United Nations conference on environment \& development. New York.

United Nations. (2012). The millenium development goals - report 2012 (p. 72). New York: United Nations. Retrieved from http://www.un.org/en/development/desa/publications/mdg-report-2012.html

Uzzell, D. L., Ruthland, A., Whistance, D., (1995). Questioning values in environmental education. In Y. Guerrier, N. Alexander, J. Chase, \& M. O'Brien (Eds.), Values and the environment: a social science perspective (pp 171-181). Chichester: John Wiley.

Von Alvensleben, R. (1998). Strategien zur Verbesserung des Image der Landwirtschaft [Strategies to improve the image of agriculture]. Presented at the Hochschultagung der Agrarwissenschaftlichen Fakultät der ChristianAlbrechts-Universität zu Kiel, Kiel.

Vonderach, G. (2004). Land-Leben gestern und heute: Studien zum sozialen Wandel ländlicher Arbeits- und Lebenswelten [Countrylife in past and present: Studies of the social change of rural working and living environments]. Münster: Lit. 
Voss, J. F., \& Schauble, L. (2014). Is interest educationally interesting? An interestrelated model of learning. In K. A. Renninger, S. Hidi, \& A. Krapp (Eds.), The role of interest in learning and development (pp. 101-120). New York: Psychology Press.

Wigfield, A., \& Cambria, J. (2010). Students' achievement values, goal orientations, and interest: Definitions, development, and relations to achievement outcomes. Developmental Review, 30(1), 1-35. doi:10.1016/j.dr.2009.12.001

Williams, G. C., Freedman, Z. R., \& Deci, E. L. (1998). Supporting autonomy to motivate patients with diabetes for glucose control. Diabetes Care, 21(10), 1644-1651. doi:10.2337/diacare.21.10.1644

Woodhouse, P. (2010). Beyond industrial agriculture? Some questions about farm size, productivity and sustainability. Journal of Agrarian Change, 10(3), 437-453. doi:10.1111/j.1471-0366.2010.00278.x

Zelezny, L. C. (1999). Educational interventions that improve environmental behaviors: A meta-analysis. The Journal of Environmental Education, 31(1), 5-14. doi:10.1080/00958969909598627

Zhu, X. (2014). Situational interest and physical activity in fitness testing: A need for pedagogical engineering. International Journal of Sport and Exercise Psychology, 12(1), 76-89. doi:10.1080/1612197X.2013.792519 


\section{Appendix}

Appendix I: Questionnaire at T0................................................................ 135

Appendix II: Questionnaire at T1 ......................................................... 140

Appendix III: Questionnaire at T2 - alternative a .................................. 145

Appendix IV: Questionnaire at T2 - alternative b ................................. 150

Appendix V: Questionnaire at T3 ............................................................ 155

Appendix VI: Curriculum Vitae ............................................................. 159 
Appendix I: Questionnaire at T0 


\section{Fragebogen zum Interesse an Landwirtschaft}

Malte Bickel \& Susanne Bögeholz

Liebe Schülerin / lieber Schüler,

wir möchten herausfinden, inwiefern du dich für verschiedene Bereiche der Landwirtschaft interessierst. Daher werden wir dich in den nächsten Wochen mehrmals zu deinem Interesse befragen.

Uns ist deine eigene Meinung wichtig. Wir bitten dich, ehrlich zu antworten. Damit kannst du dazu beitragen, dass Schulbauernhofprogramme und Biologieunterricht noch stärker an Schülerinteressen anknüpfen.

Bei den Fragen gibt es verschiedene Antwortmöglichkeiten, zum Beispiel von „Trifft nicht zu“ bis „Trifft zu“. Bitte achte darauf, dass du in jeder Zeile nur ein Kästchen ankreuzt, zum Beispiel:

Trifft nicht

zu

Das Arbeiten auf einem Bauernhof macht mir großen Spaß.

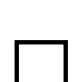

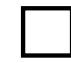

$\mathrm{x}$ Trifft zu

\section{Fülle bitte zunächst folgenden Code aus:}

Die ersten beiden Buchstaben des Vornamens deiner Mutter:

Dein Geburtstag (nur der Tag, z.B. 08, wenn du am 08. März geboren bist):

Die ersten beiden Buchstaben des Vornamens deines Vaters:

Die ersten beiden Zahlen der Hausnummer deines Zuhauses (z.B. 11, wenn du in der Hausnummer 110 wohnst):

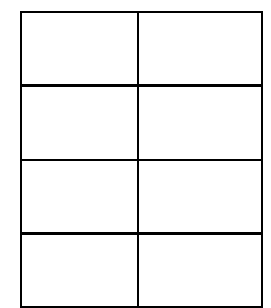

Deine Angaben werden nur für unsere Forschung verwendet.

Vielen Dank! Deine Antworten sind sehr hilfreich für uns! 


\section{Zunächst möchten wir dich bitten, einige Angaben zu dir zu machen:}

1 Ich bin Jahre alt.

2 Ich bin ein

$\square$ Mädchen $\square$ Junge

3 Ich gehe in ein(e)
$\square$ Hauptschule $\square$ Realschule
$\square$ Gymnasium $\square$ Gesamtschule
andere Schulform, und zwar:

4 Ich besuche derzeit die $\square$ 5. Klasse $\square$ 6. Klasse

\section{Kontakt zu Tieren und Landwirtschaft}

5.1 Habt ihr zu Hause ein Haustier?

$\mathrm{Ja}$ Nein

5.2 Wenn ja, was für ein Haustier?

6.1 Habt ihr zu Hause einen Gemüse- und / oder Obstgarten?<smiles>[AlH2]C1CCC1</smiles>

6.2 Hilfst du manchmal mit bei der Arbeit im Garten? (z.B. Aussäen, Unkraut jäten, Gemüse / Obst ernten)

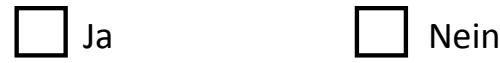

7 Wie viel Zeit verbringst du auf einem Bauernhof? (Bitte nicht den geplanten Schulbauernhofaufenthalt mit berechnen). Pro Jahr durchschnittlich ...

$\square$ keinen Tag

1-2 Tage

3-4 Tage

5-6 Tage
1-2 Wochen

3-4 Wochen

mehr als ein Monat -zwei Monate

Mehr als zwei Monate / Ich lebe auf einem Bauernhof 
Appendix I

Landwirtschaft ...

Trifft nicht

8.1 ... ist ein Thema, über das ich schon gelesen oder gehört habe.

8.2 ... beinhaltet viele Bereiche, mit denen ich vertraut bin

8.3 ... ist ein Thema, über das ich viel weiß. $\mathrm{zu}$

Trifft

$\mathrm{zu}$

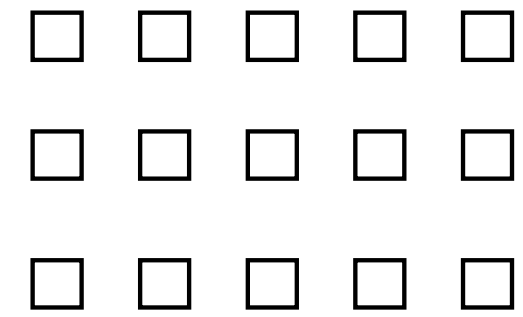

II Im Folgenden geht es um dein Interesse an verschiedenen Bereichen von Landwirtschaft. Die Bereiche werden in der Box mit Beispielen veranschaulicht. Bitte lese diese zunächst durch.

Tierhaltung (z.B. Kühe melken, Schweine füttern, Eier sammeln)

Ackerbau (z.B. Getreide säen, Kartoffeln ernten, Rüben roden)

Gemüse- und Obstbau (z.B. Gemüsebeete vorbereiten, Unkraut jäten, Obst ernten)

Verarbeitung von Lebensmitteln (z.B. Brot backen, Frischkäse herstellen, Marmelade kochen)

Landtechnik (Funktionsweise und Einsatz von Maschinen wie Traktor, Melkmaschine, Mähdrescher)

Kreuze bitte an, inwiefern die folgenden Aussagen auf dich zutreffen.

1. Wenn ich mich mit ... beschäftige, bin ich

gelangweilt

interessiert

... Tierhaltung
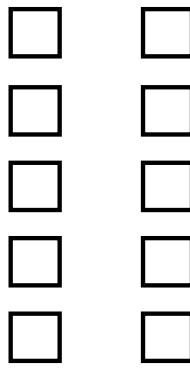

... Ackerbau

... Gemüse- und Obstbau

... Verarbeitung von Lebensmitteln

... Landtechnik

2. Wenn ich mich mit ... beschäftige, bin ich

teilnahmslos angeregt

... Tierhaltung .

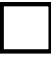

... Ackerbau

... Gemüse- und Obstbau

... Verarbeitung von Lebensmitteln

... Landtechnik
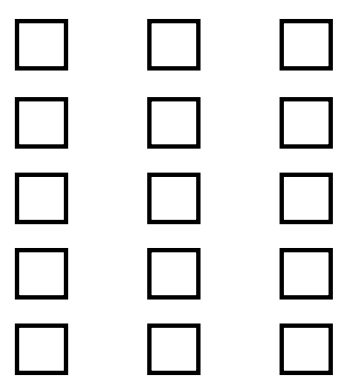
3. Wenn ich mich mit ... beschäftige, bin ich

unkonzentriert aufmerksam

... Tierhaltung . .
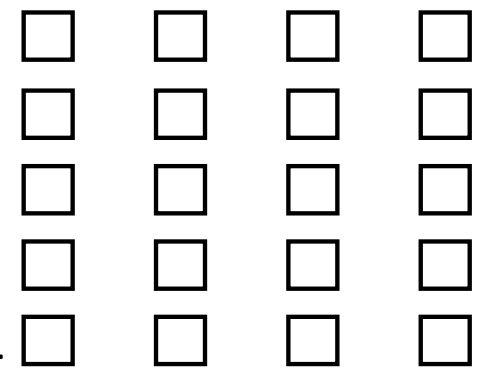

... Landtechnik

4. Das Thema ... ist für mich

unwichtig

bedeutsam

\section{... Tierhaltung}
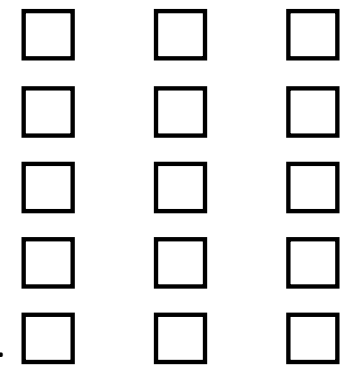

... Ackerbau

... Gemüse- und Obstbau

Verarbeitung von Lebensmitteln

... Landtechnik.

VI Nun geht es darum, wie eklig du die im Folgenden beschriebenen Situationen findest. Bitte gehe die Aussagen der Reihe nach durch, und setze in jede Zeile ein Kreuz.

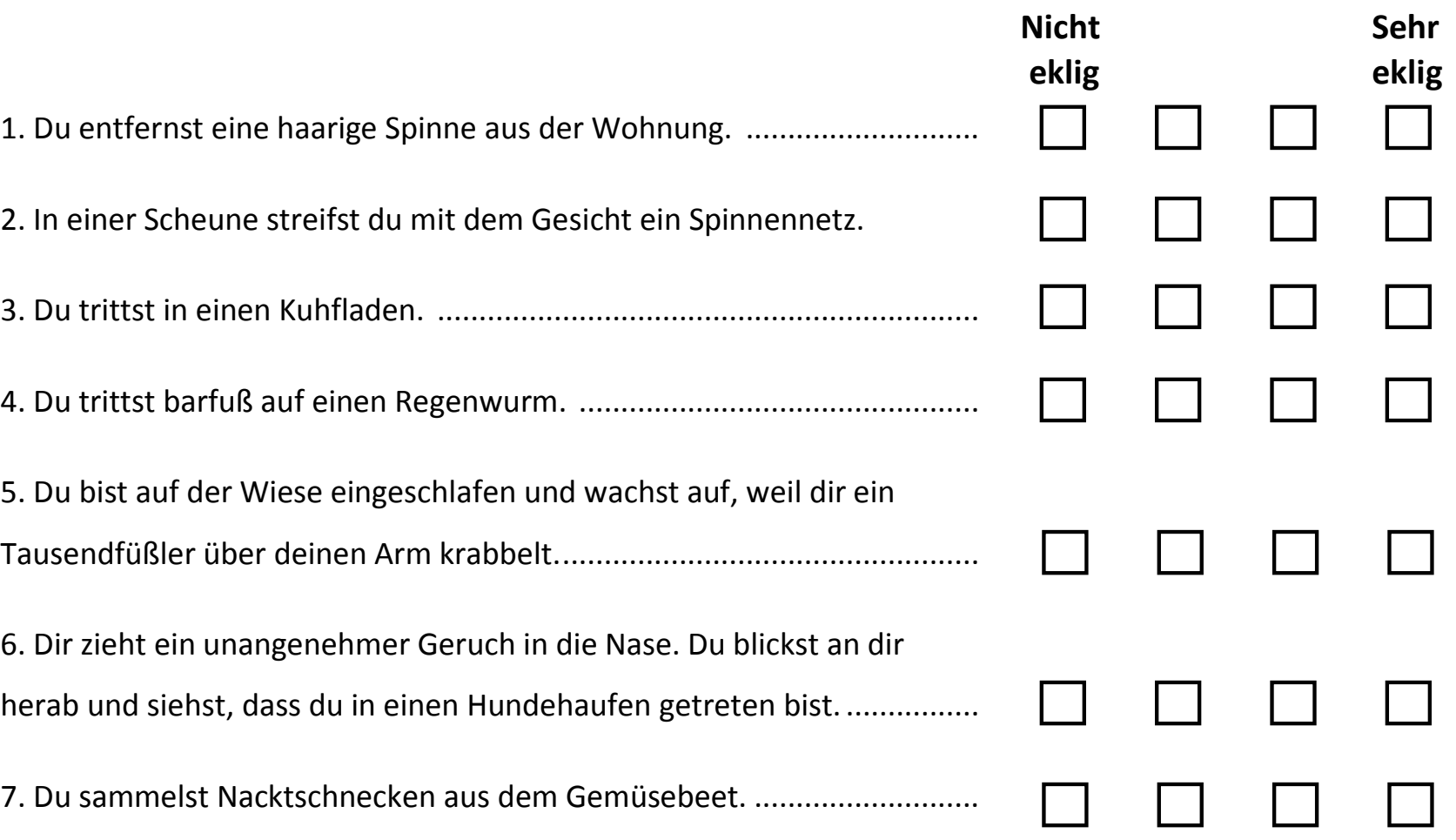


Appendix II: Questionnaire at T1 


\section{Fragebogen zum Interesse an Landwirtschaft}

Malte Bickel \& Susanne Bögeholz

Liebe Schülerin / lieber Schüler,

du hast eine ganze Woche auf dem Schulbauernhof verbracht. Nun möchten wir herausfinden, wie du deine Mitarbeit auf dem Schulbauernhof erlebt hast und was dich interessiert.

Bei den Fragen gibt es verschiedene Antwortmöglichkeiten, zum Beispiel von „Trifft nicht zu“ bis „Trifft zu“. Bitte achte darauf, dass du in jeder Zeile nur ein Kästchen ankreuzt, zum Beispiel:

Trifft nicht

zu

Trifft

Das Arbeiten auf einem Bauernhof macht mir großen Spaß. zu

\section{$\mathrm{X}$}

\section{Fülle bitte zunächst wieder den Code aus:}

Die ersten beiden Buchstaben des Vornamens deiner Mutter:

Dein Geburtstag (nur der Tag, z.B. 08, wenn du am 08. März geboren bist):

Die ersten beiden Buchstaben des Vornamens deines Vaters:

Die ersten beiden Zahlen der Hausnummer, deines Zuhauses (z.B. 11, wenn du in der Hausnummer 110 wohnst):

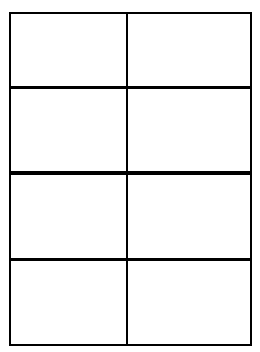

Bitte nenne Stichworte, in welchem Bereich du an den Wochentagen auf dem Schulbauernhof mitgearbeitet hast (z.B. Tiere versorgen, Garten).

Montag:

Dienstag:

Mittwoch:

Donnerstag:

Freitag:

\section{Vielen Dank! Deine Antworten sind sehr hilfreich für uns!}


I Im Folgenden geht es um dein Interesse an verschiedenen Bereichen von Landwirtschaft, also nicht um das Arbeiten auf dem Schulbauernhof!

Die Bereiche werden in der Box mit Beispielen veranschaulicht. Bitte lese diese zunächst durch.

Tierhaltung (z.B. Kühe melken, Schweine füttern, Eier sammeln)

Ackerbau (z.B. Getreide säen, Kartoffeln ernten, Rüben roden)

Gemüse- und Obstbau (z.B. Gemüsebeete vorbereiten, Unkraut jäten, Obst ernten)

Verarbeitung von Lebensmitteln (z.B. Brot backen, Frischkäse herstellen, Marmelade kochen)

Landtechnik (Funktionsweise und Einsatz von Maschinen wie Traktor, Melkmaschine, Mähdrescher)

Kreuze bitte an, inwiefern die folgenden Aussagen auf dich zutreffen.

1. Wenn ich mich mit ... beschäftige, bin ich

gelangweilt

interessiert

... Tierhaltung .....

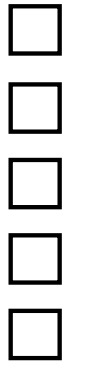

$\square$

... Ackerbau

... Gemüse- und Obstbau

... Verarbeitung von Lebensmitteln

... Landtechnik

2. Wenn ich mich mit ... beschäftige, bin ich

teilnahmslos angeregt

... Tierhaltung.
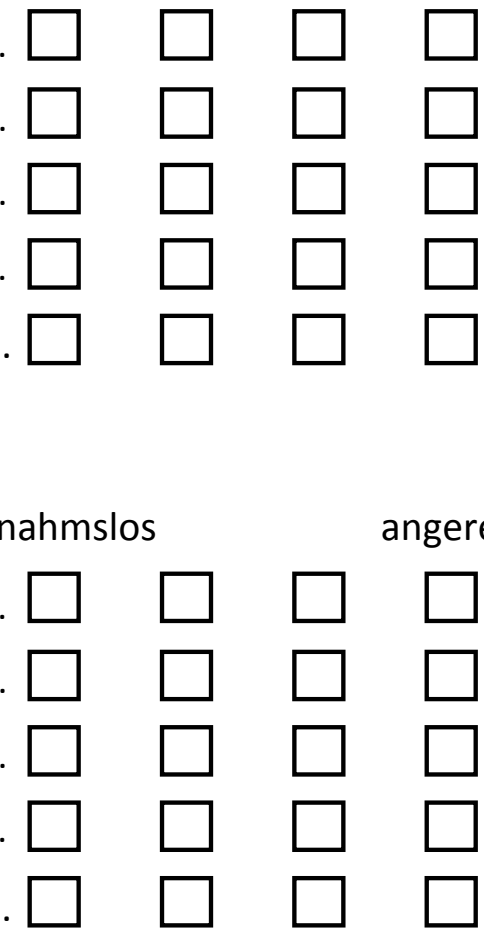

... Ackerbau
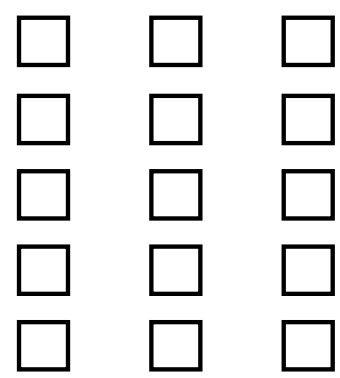

... Gemüse- und Obstbau

... Verarbeitung von Lebensmitteln

... Landtechnik.

unkonzentriert

aufmerksam

3. Wenn ich mich mit ... beschäftige, bin ich
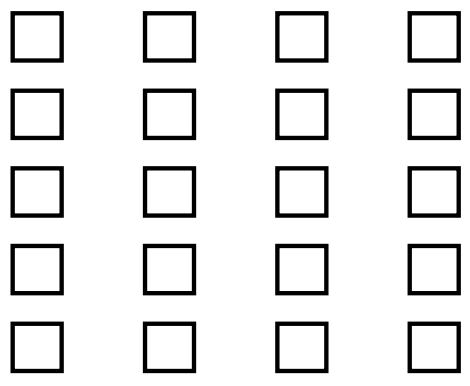
Appendix II

4. Das Thema ... ist für mich

unwichtig

bedeutsam

... Tierhaltung
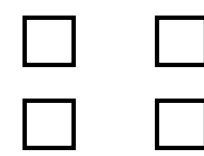

$\square$

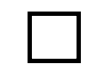

... Ackerbau

... Gemüse- und Obstbau
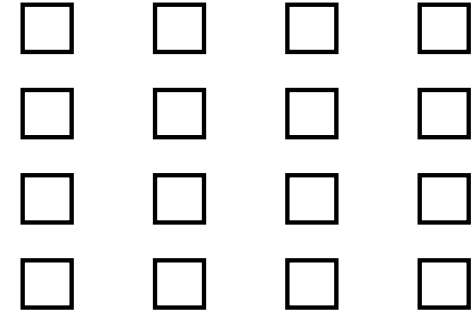

... Verarbeitung von Lebensmitteln
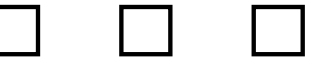

... Landtechnik

II Die folgenden Aussagen beziehen sich auf deine Mitarbeit auf dem Schulbauernhof. Bitte kreuze in jeder Zeile an, inwieweit die Aussage für dich zutrifft.

Die Mitarbeit auf dem Schulbauernhof ...

Trifft nicht

Trifft

1. ... begeistert mich.

zu

zu
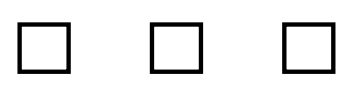

2. ... ist spannend.
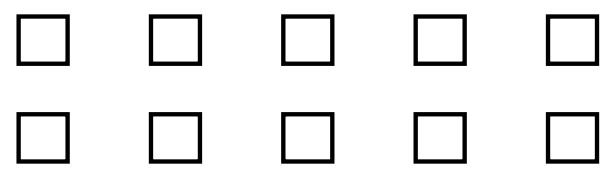

3. ... finde ich interessant.
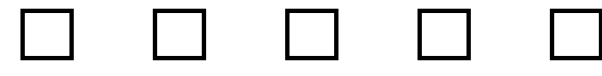

4. ... macht mir Spaß.
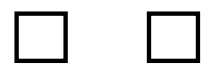

$\square$

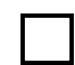

5. ... ist kompliziert.
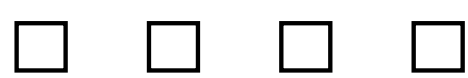

6. ... ist für mich neu.
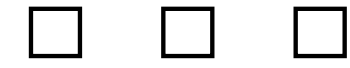

7. ... spricht mich an.

Trifft nicht

zu

8. Bei der Mitarbeit auf dem Schulbauernhof lerne ich einiges, was mir vorher nicht bekannt war.

9. Es ist für mich herausfordernd, auf dem Schulbauernhof zu arbeiten.
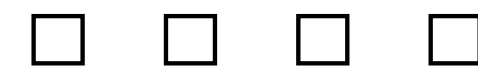

10. Bei der Arbeit auf dem Schulbauernhof bin ich konzentriert.

11. Viele der Arbeiten auf dem Schulbauernhof sind für mich schwierig auszuführen.

12. Ich möchte alles, was wir auf dem Schulbauernhof machen können, erkunden.

13. Beim Arbeiten auf dem Schulbauernhof bin ich sehr aufmerksam.

14. Ich mache viele der Arbeiten auf dem Schulbauernhof zum ersten Mal. 
III In diesem Teil geht es darum, wie du dich beim Mitarbeiten auf dem Schulbauernhof fühlst. Bitte kreuze auch hier in jeder Zeile an, inwieweit die Aussage auf dich zutrifft!

Beim Mitarbeiten auf dem Schulbauernhof ...

1. ... bin ich in der Lage, die Aufgaben gut zu erledigen.

2. ... bin ich zufrieden mit meiner erbrachten Leistung.

3. ... ermutigen mich die Bauern, Fragen zu stellen.

4. ... bin ich gerne mit meinen Klassenkameraden zusammen

5. ... habe ich meistens das Gefühl, dass ich wirklich etwas schaffe.

6. ... verstehe ich mich mit meinen Gruppenmitgliedern gut.

7. ... scheinen meine Klassenkameraden mich zu mögen.

8. ... bin ich in der Lage neue Fähigkeiten zu erlernen.

9. ... sind meine Mitschüler sehr freundlich zu mir.

10. Die Bauern sorgen dafür, dass ich die Arbeitsziele verstehe und weiß, was zu tun ist.

11. Die Bauern beantworten meine Fragen sorgfältig.

12. Die Bauern vertrauen in meine Fähigkeiten, die Arbeiten auf dem Schulbauernhof gut zu machen.

Trifft nicht

zu

Trifft

zu
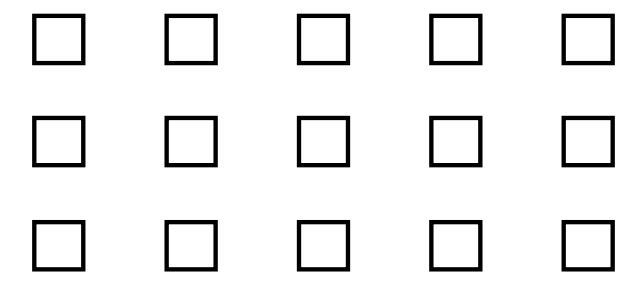

$\square$
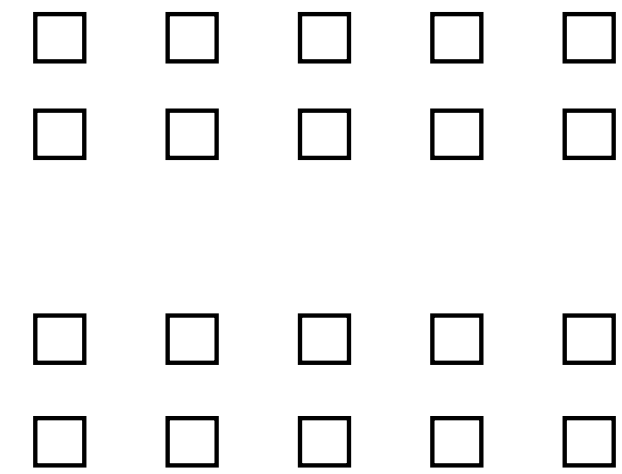

$\square$
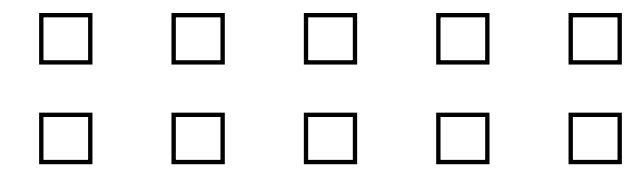

$\square$
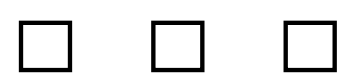

$\square \quad \square$
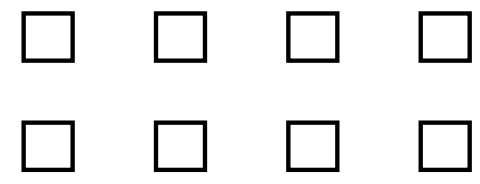

..
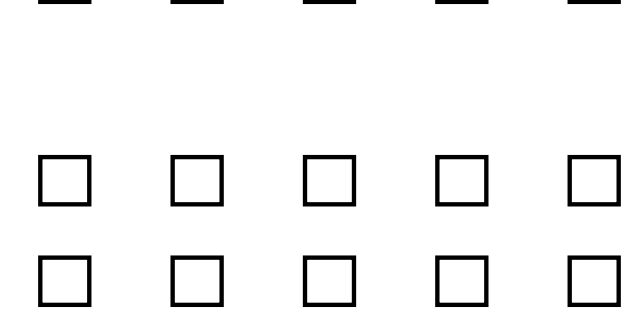

..
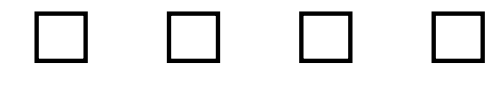


\section{Appendix III: Questionnaire at T2 - Variante $\mathbf{a}^{25}$}

\footnotetext{
${ }^{25}$ Anmerkung: Der Fragebogen wurde in zwei Varianten (a und b) verwendet, die jeweils von der Hälfte der Schülerinnen und Schüler einer Klasse ausgefüllt wurden. Variiert wurde die Zuordnung der Items zur Messung des situationalen Interesses an der schulischen Lerneinheit. Jeweils sieben Items bezogen sich auf eine der beiden Doppelstunden der Lerneinheit. So wurde sichergestellt, dass das situationale Interesse an den beiden Doppelstunden nicht aufgrund der Verwendung verschiedener Items unterschiedlich bewertet wurde.
} 


\section{Fragebogen zum Interesse an Landwirtschaft}

Malte Bickel \& Susanne Bögeholz

Liebe Schülerin / lieber Schüler,

du hast einiges über das Verhalten und die Haltung von Hühnern gelernt und über den Anbau von Kartoffeln. Nun möchten wir herausfinden, wie du die Unterrichtsstunden zur Hühnerhaltung und zur Kartoffel erlebt hast.

\section{Fülle bitte zunächst wieder den Code aus:}

Die ersten beiden Buchstaben des Vornamens deiner Mutter:

Dein Geburtstag (nur der Tag, z.B. 08, wenn du am 08. März geboren bist):

Die ersten beiden Buchstaben des Vornamens deines Vaters:

Die ersten beiden Zahlen der Hausnummer, deines Zuhauses (z.B. 11, wenn du in der Hausnummer 110 wohnst):

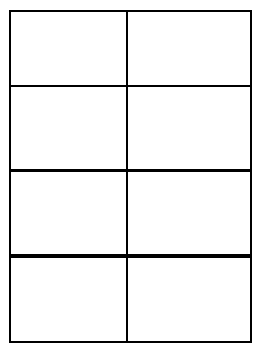

Wir danken dir herzlich für deine Antworten! 
I Im Folgenden geht es um dein Interesse an verschiedenen Bereichen von Landwirtschaft, also nicht um die Unterrichtsstunden!

Die Bereiche werden in der Box mit Beispielen veranschaulicht. Bitte lese diese zunächst durch.

Tierhaltung (z.B. Kühe melken, Schweine füttern, Eier sammeln)

Ackerbau (z.B. Getreide säen, Kartoffeln ernten, Rüben roden)

Gemüse- und Obstbau (z.B. Gemüsebeete vorbereiten, Unkraut jäten, Obst ernten)

Verarbeitung von Lebensmitteln (z.B. Brot backen, Frischkäse herstellen, Marmelade kochen)

Landtechnik (Funktionsweise und Einsatz von Maschinen wie Traktor, Melkmaschine, Mähdrescher)

Kreuze bitte an, inwiefern die folgenden Aussagen auf dich zutreffen.

1. Wenn ich mich mit ... beschäftige, bin ich

gelangweilt

interessiert

... Tierhaltung
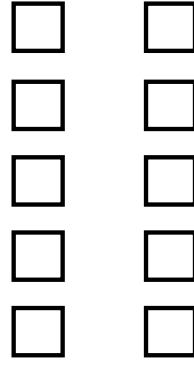

... Ackerbau

... Gemüse- und Obstbau

... Verarbeitung von Lebensmitteln

... Landtechnik
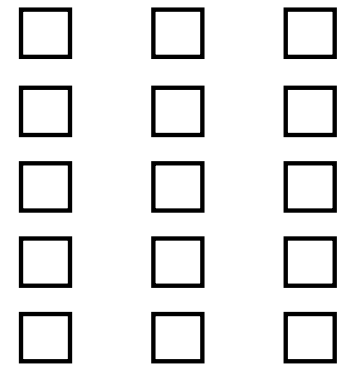

2. Wenn ich mich mit ... beschäftige, bin ich

teilnahmslos

angeregt

... Tierhaltung .....
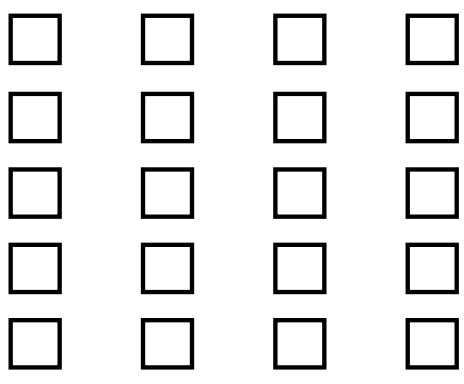

... Ackerbau

... Gemüse- und Obstbau

... Verarbeitung von Lebensmitteln

... Landtechnik

3. Wenn ich mich mit $\ldots$ beschäftige, bin ich

unkonzentriert

aufmerksam

... Tierhaltung
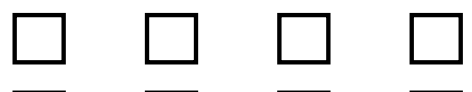

... Ackerbau

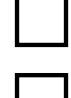

... Gemüse- und Obstbau

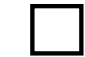

... Verarbeitung von Lebensmitteln

... Landtechnik
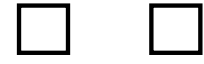
4. Das Thema ... ist für mich

unwichtig bedeutsam

... Tierhaltung

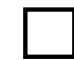

$\square$
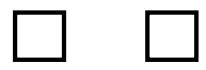

... Ackerbau

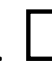

... Gemüse- und Obstbau

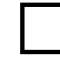

$\square$

$\square$

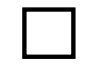

... Verarbeitung von Lebensmitteln

$\square$

$\square$
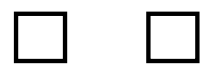

... Landtechnik

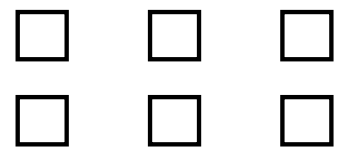

II Die folgenden Aussagen beziehen sich auf die Unterrichtsstunden zur Hühnerhaltung. Bitte kreuze in jeder Zeile an, inwieweit die Aussage für dich zutrifft.

Der Unterricht zur Hühnerhaltung

Trifft nicht

1. ... begeistert mich.
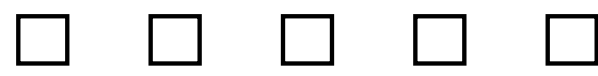

2. ... ist interessant.<smiles>C1CCC1</smiles><smiles>C1CCC1</smiles><smiles>C1CCC1</smiles><smiles>C1CCC1</smiles><smiles>C1CCC1</smiles>

3. ... ist kompliziert.
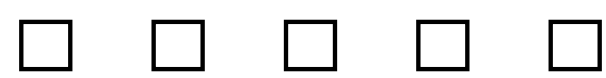

\section{Trifft nicht}

4. Beim Unterricht zur Hühnerhaltung bin ich konzentriert.
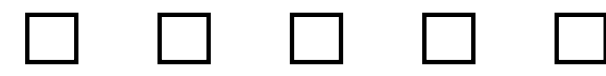

5. Ich möchte alles über Hühnerhaltung erkunden.
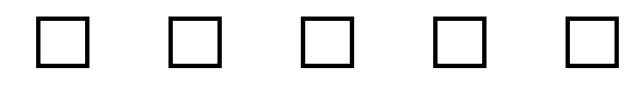

6. Beim Unterricht zur Hühnerhaltung lerne ich einiges, was mir vorher nicht bekannt war.
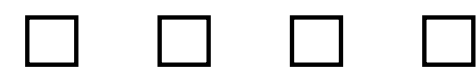

7. Der Unterricht zur Hühnerhaltung ist für mich herausfordernd.
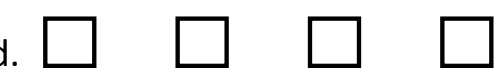
Die nächsten Aussagen beziehen sich auf die Unterrichtsstunden über die Kartoffel. Bitte kreuze auch hier in jeder Zeile an, inwieweit die Aussage für dich zutrifft.

Der Unterricht über die Kartoffel ...

Trifft nicht

Trifft

zu

zu

Zu

8. ... spricht mich an.

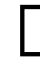
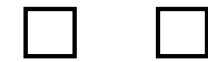

$\square$

$\square$

9. ... macht mir Spaß.

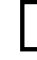
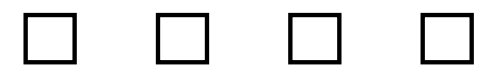

10. ... ist spannend.
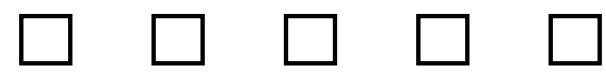

Trifft nicht

zu

11. Die Informationen über die Kartoffel sind für mich neu.

(1)

$\square$

$\square$

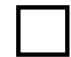

$\square$

12. Beim Unterricht über die Kartoffel bin ich sehr aufmerksam.
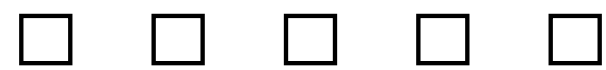

13. Die Aufgaben beim Unterricht über die Kartoffel sind für mich schwierig zu beantworten.
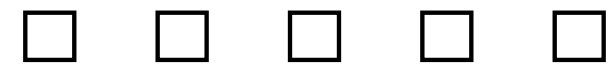

14. Beim Unterricht über die Kartoffel höre ich viele Informationen zum ersten Mal.
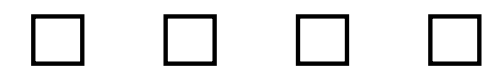

\section{Vielen Dank für deine Antworten!}




\section{Appendix IV: Questionnaire at T2 - Variante $\mathbf{b}^{26}$}

${ }^{26}$ Anmerkung: Der Fragebogen wurde in zwei Varianten ( $\mathrm{a}$ und b) verwendet, die jeweils von der Hälfte der Schülerinnen und Schüler einer Klasse ausgefüllt wurden. Variiert wurde die Zuordnung der Items zur Messung des situationalen Interesses an der schulischen Lerneinheit. Jeweils sieben Items bezogen sich auf eine der beiden Doppelstunden der Lerneinheit. So wurde sichergestellt, dass das situationale Interesse an den beiden Doppelstunden nicht aufgrund der Verwendung verschiedener Items unterschiedlich bewertet wurde. 


\section{Fragebogen zum Interesse an Landwirtschaft}

Malte Bickel \& Susanne Bögeholz

Liebe Schülerin / lieber Schüler,

du hast einiges über das Verhalten und die Haltung von Hühnern gelernt und über den Anbau von Kartoffeln. Nun möchten wir herausfinden, wie du die Unterrichtsstunden zur Hühnerhaltung und zur Kartoffel erlebt hast.

\section{Fülle bitte zunächst wieder den Code aus:}

Die ersten beiden Buchstaben des Vornamens deiner Mutter:

Dein Geburtstag (nur der Tag, z.B. 08, wenn du am 08. März geboren bist):

Die ersten beiden Buchstaben des Vornamens deines Vaters:

Die ersten beiden Zahlen der Hausnummer, deines Zuhauses (z.B. 11, wenn du in der Hausnummer 110 wohnst):

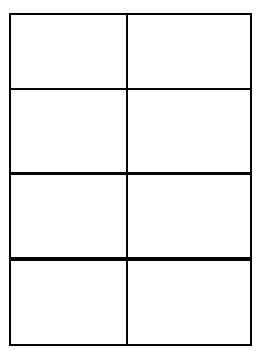

Wir danken dir herzlich für deine Antworten! 
I Im Folgenden geht es um dein Interesse an verschiedenen Bereichen von Landwirtschaft, also nicht um die Unterrichtsstunden!

Die Bereiche werden in der Box mit Beispielen veranschaulicht. Bitte lese diese zunächst durch.

Tierhaltung (z.B. Kühe melken, Schweine füttern, Eier sammeln)

Ackerbau (z.B. Getreide säen, Kartoffeln ernten, Rüben roden)

Gemüse- und Obstbau (z.B. Gemüsebeete vorbereiten, Unkraut jäten, Obst ernten)

Verarbeitung von Lebensmitteln (z.B. Brot backen, Frischkäse herstellen, Marmelade kochen)

Landtechnik (Funktionsweise und Einsatz von Maschinen wie Traktor, Melkmaschine, Mähdrescher)

Kreuze bitte an, inwiefern die folgenden Aussagen auf dich zutreffen.

1. Wenn ich mich mit ... beschäftige, bin ich

gelangweilt

interessiert

... Tierhaltung

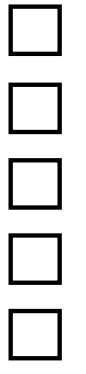

$\square$

... Ackerbau

... Gemüse- und Obstbau

... Verarbeitung von Lebensmitteln

... Landtechnik

2. Wenn ich mich mit ... beschäftige, bin ich

teilnahmslos

angeregt

... Tierhaltung .....
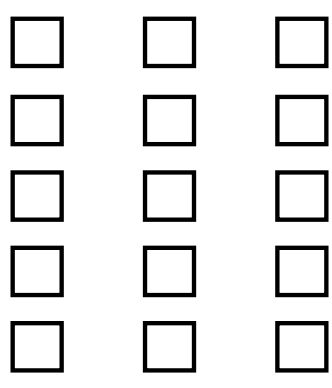

... Ackerbau

... Gemüse- und Obstbau

... Verarbeitung von Lebensmitteln

... Landtechnik
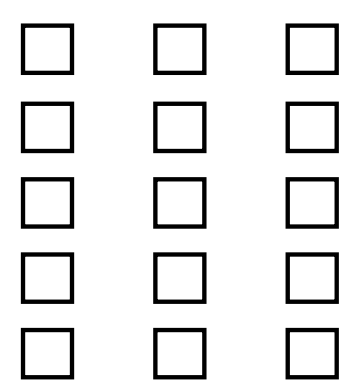

3. Wenn ich mich mit ... beschäftige, bin ich

unkonzentriert

aufmerksam

... Tierhaltung
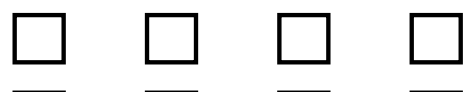

... Ackerbau

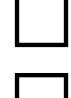

... Gemüse- und Obstbau

... Verarbeitung von Lebensmitteln

... Landtechnik
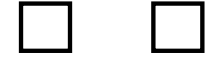
4. Das Thema ... ist für mich

unwichtig bedeutsam

... Tierhaltung

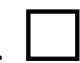

$\square$

$\square$

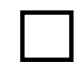

... Ackerbau

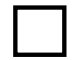

$\square \quad \square$

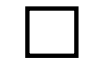

... Gemüse- und Obstbau
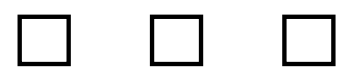

... Verarbeitung von Lebensmitteln

$\square$

... Landtechnik

\author{

}
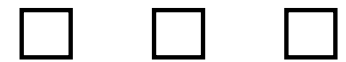

II Die folgenden Aussagen beziehen sich auf die Unterrichtsstunden über die Kartoffel. Bitte kreuze in jeder Zeile an, inwieweit die Aussage für dich zutrifft.

Der Unterricht über die Kartoffel ...

1. ... begeistert mich.

2. ... ist interessant.

3. ... ist kompliziert.
Trifft nicht

zu

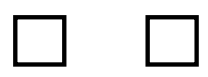

$\square$
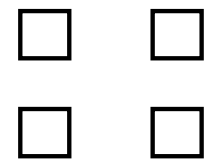

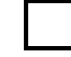

Trifft nicht

zu

4. Beim Unterricht über die Kartoffel bin ich konzentriert.

5. Ich möchte alles über die Kartoffel erkunden.

6. Beim Unterricht über die Kartoffel lerne ich einiges, was mir vorher nicht bekannt war.

7. Der Unterricht über die Kartoffel ist für mich herausfordernd.

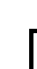

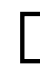

+
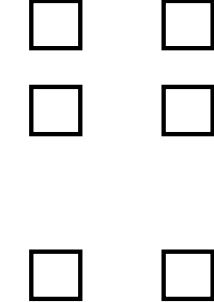

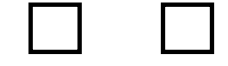

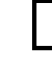
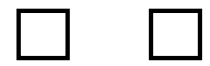
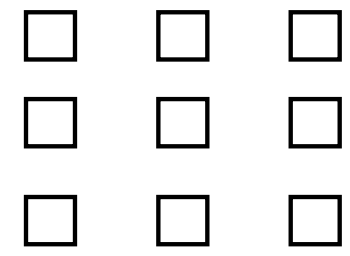

Trifft

zu
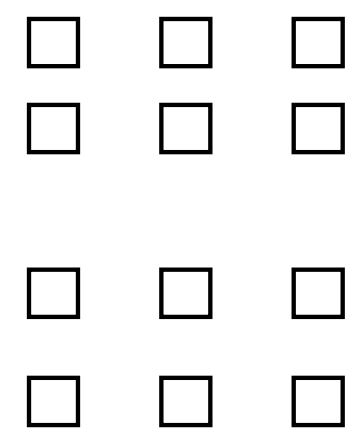
Die nächsten Aussagen beziehen sich auf die Unterrichtsstunden zur Hühnerhaltung. Bitte kreuze auch hier in jeder Zeile an, inwieweit die Aussage für dich zutrifft.

Der Unterricht zur Hühnerhaltung ...

8. ... spricht mich an.

9. ... macht mir Spaß.

10. ... ist spannend.

\section{Trifft nicht}

zu

11. Die Informationen zur Hühnerhaltung sind für mich neu.

12. Beim Unterricht zur Hühnerhaltung bin ich sehr aufmerksam.

13. Die Aufgaben beim Unterricht zur Hühnerhaltung sind für mich schwierig zu beantworten.

14. Beim Unterricht zur Hühnerhaltung höre ich viele Informationen zum ersten Mal.

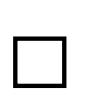

Trifft nicht

zu
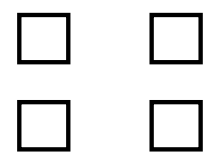

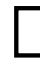

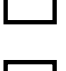

Trifft

zu

$\square$

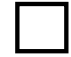

$\square$

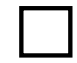

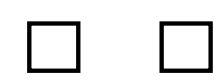
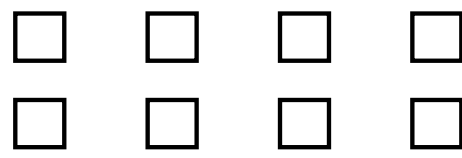

$\square$
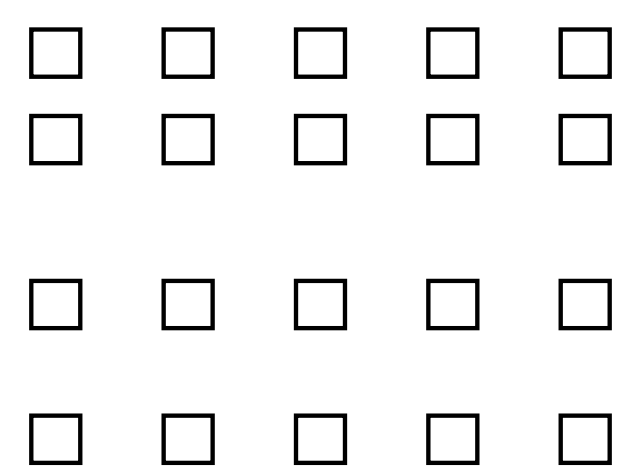

\section{Vielen Dank für deine Antworten!}


Appendix V: Questionnaire at T3 


\section{Fragebogen zum Interesse an Landwirtschaft}

Malte Bickel \& Susanne Bögeholz

Liebe Schülerin / lieber Schüler,

heute möchten wir dich ein letztes mal zu deinem Interesse an Landwirtschaft befragen, um zu sehen, ob und wie es sich verändert hat. Damit wir aus deinen Antworten und denen von vielen anderen Schülerinnen und Schülern gute Ergebnisse erzielen können, bitten wir dich, ehrliche Antworten zu geben. Vielen Dank!

\section{Fülle bitte zunächst wieder den Code aus:}

Die ersten beiden Buchstaben des Vornamens deiner Mutter:

Dein Geburtstag (nur der Tag, z.B. 08, wenn du am 08. März geboren bist):

Die ersten beiden Buchstaben des Vornamens deines Vaters:

Die ersten beiden Zahlen der Hausnummer, deines Zuhauses (z.B. 11, wenn du in der Hausnummer 110 wohnst):

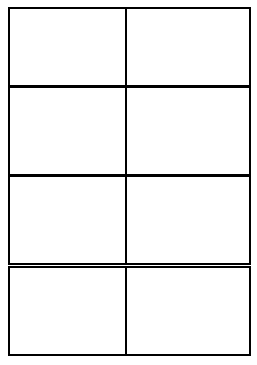


I Hier geht es um dein Interesse an verschiedenen Bereichen von Landwirtschaft.

Die Bereiche werden in der Box mit Beispielen veranschaulicht. Bitte lese diese zunächst durch.

Tierhaltung (z.B. Kühe melken, Schweine füttern, Eier sammeln)

Ackerbau (z.B. Getreide säen, Kartoffeln ernten, Rüben roden)

Gemüse- und Obstbau (z.B. Gemüsebeete vorbereiten, Unkraut jäten, Obst ernten)

Verarbeitung von Lebensmitteln (z.B. Brot backen, Frischkäse herstellen, Marmelade kochen)

Landtechnik (Funktionsweise und Einsatz von Maschinen wie Traktor, Melkmaschine, Mähdrescher)

Kreuze bitte an, inwiefern die folgenden Aussagen auf dich zutreffen.

1. Wenn ich mich mit ... beschäftige, bin ich

gelangweilt interessiert

... Tierhaltung

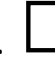

$\square$

$\square \quad \square$

... Ackerbau
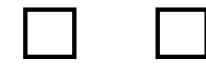

$\square$

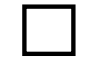

... Gemüse- und Obstbau
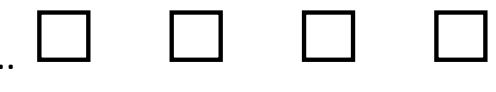

... Verarbeitung von Lebensmitteln
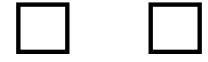

$\square$

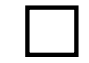

... Landtechnik
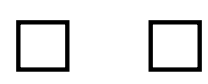

$\square$

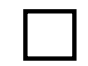

2. Wenn ich mich mit ... beschäftige, bin ich

teilnahmslos

angeregt

... Tierhaltung
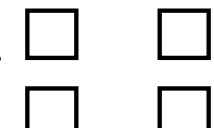

$\square$

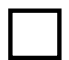

... Ackerbau
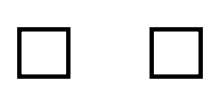

$\square$

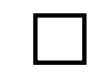

... Gemüse- und Obstbau<smiles>C1CCC1</smiles><smiles>[CH]</smiles>

$\square$

... Verarbeitung von Lebensmitteln
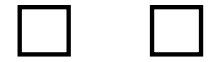

... Landtechnik 
3. Wenn ich mich mit ... beschäftige, bin ich

unkonzentriert aufmerksam

... Tierhaltung

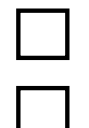

$\square$

$\square$

$\square$

... Ackerbau

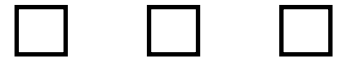

... Gemüse- und Obstbau

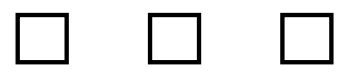

... Verarbeitung von Lebensmitteln

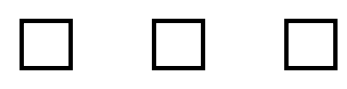

... Landtechnik
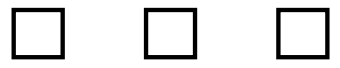

4. Das Thema ... ist für mich

unwichtig

bedeutsam

... Tierhaltung

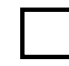

$\square$

$\square$

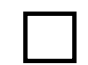

... Ackerbau

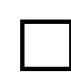

$\square$

$\square$

... Gemüse- und Obstbau

$\square \quad \square \quad \square$

... Verarbeitung von Lebensmitteln

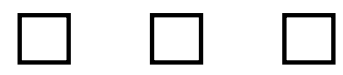

... Landtechnik

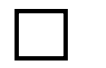

$\square$

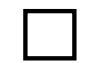

Toll, dass du uns so viele Fragen beantwortet hast! Vielen Dank! 


\section{Appendix VI: Curriculum Vitae}




\section{Curriculum Vitae}

Wissenschaftliche Tätigkeiten

\begin{tabular}{ll}
\hline $10 / 2010-09 / 2014$ & Promotion (Stipendiat) \\
& im Promotionsstudiengang „Biodiversität und Gesellschaft“, Fakultät \\
& für Biologie und Psychologie, Albrecht-von-Haller-Institut, Abteilung \\
& Didaktik der Biologie, Universität Göttingen
\end{tabular}

Seit $04 / 2011$

Lehrbeauftragter

im Modul „Umweltkommunikation“, Fachbereich Ökologische

Agrarwissenschaften, Universität Kassel, Witzenhausen

$05 / 2009-05 / 2010$

Wissenschaftlicher Mitarbeiter

im Fachgebiet Agrar- und Lebensmittelmarketing, Fachbereich

Ökologische Agrarwissenschaften, Universität Kassel,

Witzenhausen

10/2007 - 10/2009 Wissenschaftliche / Studentische Hilfskraft

im Fachgebiet Agrar- und Lebensmittelmarketing, Fachbereich

Ökologische Agrarwissenschaften, Universität Kassel,

Witzenhausen

04/2007-05/2009

Studium Int. Food Business and Consumer Studies

am Fachbereich Ökologische Agrarwissenschaften, Universität Kassel; Abschluss: M.Sc.

$10 / 2001-12 / 2006$

Studium Ökologische Agrarwissenschaften

am Fachbereich Ökologische Agrarwissenschaften, Universität Kassel; Abschluss: Diplom I

Schulausbildung

$\begin{array}{ll}1997-2000 & \text { Gymnasium Philippinum, Marburg, Abitur } \\ 1993-1997 & \text { Richtsberg Gesamtschule, Marburg } \\ 1987-1993 & \text { Mittelpunktschule Cappel (Grundschule mit Förderstufe), Marburg }\end{array}$

